VILNIAUS GEDIMINO TECHNIKOS UNIVERSITETAS

Dainius LEONAVIČIUS

\title{
CEMENTINIO KOMPOZITO SU POLISTIRENINIO PUTPLASČIO TECHNOLOGINĖMIS ATLIEKOMIS KŪRIMAS
}

DAKTARO DISERTACIJA

TECHNOLOGIJOS MOKSLAI,

MEDŽIAGŲ INŽINERIJA (T 008)

Vilnius, 2021 
Disertacija rengta 2016-2021 metais Vilniaus Gedimino technikos universitete.

Vadovas

dr. Ina PUNDIENĖ (Vilniaus Gedimino technikos universitetas, medžiagų inžinerija - T 008).

Vilniaus Gedimino technikos universiteto Medžiagų inžinerijos mokslo krypties disertacijos gynimo taryba:

\section{Pirmininkas}

dr. Viktor GRIBNIAK (Vilniaus Gedimino technikos universitetas, medžiagų inžinerija - T 008).

\section{Nariai:}

prof. dr. Mindaugas DAUKŠYS (Kauno technologijos universitetas, statybos inžinerija - T 002),

dr. Genadijs SAHMENKO (Rygos technikos universitetas, Latvija, medžiagu inžinerija - T 008),

doc. dr. Jelena ŠKAMAT (Vilniaus Gedimino technikos universitetas, medžiagų inžinerija - T 008),

prof. dr. Juozas VALIVONIS (Vilniaus Gedimino technikos universitetas, statybos inžinerija - T 002).

Disertacija bus ginama viešame Medžiagų inžinerijos mokslo krypties disertacijos gynimo tarybos posėdyje 2021 m. birželio 9 d. 10 val. Vilniaus Gedimino technikos universiteto senato posėdžių salèje.

Adresas: Sauletekio al. 11, LT-10223 Vilnius, Lietuva.

Tel. (8 5) 274 4956; faksas (8 5) 270 0112; el. paštas doktor@vilniustech.lt

Pranešimai apie numatomą ginti disertaciją išsiųsti $2021 \mathrm{~m}$. gegužès $7 \mathrm{~d}$.

Disertaciją galima peržiūrèti Vilniaus Gedimino Technikos universiteto talpykloje http://dspace.vgtu.lt ir Vilniaus Gedimino technikos universiteto bibliotekoje (Sauletekio al. 14, LT-10223 Vilnius, Lietuva).

Vilniaus Gedimino technikos universiteto 2021-023-M mokslo literatūros knyga

doi: $10.20334 / 2021-023-\mathrm{M}$

(C) Vilniaus Gedimino technikos universitetas, 2021

(C) Dainius Leonavičius, 2021

dainius.leonavičius@vilniustech.lt 
VILNIUS GEDIMINAS TECHNICAL UNIVERSITY

Dainius LEONAVIČIUS

\section{DEVELOPMENT OF CEMENT COMPOSITE WITH POLYSTYRENE FOAM TECHNOLOGICAL WASTE}

DOCTORAL DISSERTATION

TECHNOLOGICAL SCIENCES,

MATERIALS ENGINEERING (T 008)

Vilnius, 2021 
Doctoral dissertation was prepared at Vilnius Gediminas Technical University in 2016-2021.

\section{Supervisor}

Dr Ina PUNDIENE (Vilnius Gediminas Technical University, Materials Engineering - T 008).

The Dissertation Defence Council of Scientific Field of Materials Engineering of Vilnius Gediminas Technical University:

\section{Chairman}

Dr Viktor GRIBNIAK (Vilnius Gediminas Technical University, Materials Engineering - T 008).

\section{Members:}

Prof. Dr Mindaugas DAUKŠYS (Kaunas University of Technology, Civil Engineering - T 002),

Dr Genadijs SAHMENKO (Riga Technical University, Latvia, Materials Engineering - T 008),

Assoc. Prof. Dr Jelena ŠKAMAT (Vilnius Gediminas Technical University, Materials Engineering - T 008),

Prof. Dr Juozas VALIVONIS (Vilnius Gediminas Technical University, Civil Engineering - T 002).

The dissertation will be defended at the public meeting of the Dissertation Defence Council of Materials Engineering in the Senate Hall of Vilnius Gediminas Technical University at 10 a. m. on 9 June 2021.

Address: Saulètekio al. 11, LT-10223 Vilnius, Lithuania.

Tel.: +370 5274 4956; fax +370 5270 0112; E-mail: doktor@vilniustech.lt

A notification on the intend defending of the dissertation was send on 7 May 2021. A copy of the doctoral dissertation is available for review at Vilnius Gediminas Technical University repository http://dspace.vgtu.lt and at the Library of Vilnius Gediminas Technical University (Sauletekio al. 14, LT-10223 Vilnius, Lithuania). 


\section{Reziumè}

Disertacijoje nagrinejjamas anglies nanovamzdelių (MWCNTs) ir cheminių betono ịmaišų (plastifikuojančių betono įmaišų, orą ịtraukiančių) poveikis cemento tešlai, sukietejusio cemento akmens savybèms, cementinis kompozitas su lengvaisiais užpildais (polistireninio putplasčio trupintos atliekos (PPT) ir gamybos metu susidariusios frezavimo atliekos (PPN)). Disertacijos tikslas - sukurti cementinị lengvajij kompozitą su PPT ir PPN užpildų atliekomis naudojant nanopriedą ir efektyvias chemines betono įmaišas.

Disertaciją sudaro įvadas, trys skyriai, bendrosios išvados, naudotos literatūros ir autoriaus publikacijų disertacijos tema sąrašai, santrauka anglų kalba bei trys priedai.

Pirmasis skyrius skirtas literatūros analizei. Jame pateikta informacija apie MWCNTs dispergavimą, MWCNTs įtaką cemento tešlos ir sukietejusio cemento akmens fizikinèms ir mechaninèms savybèms, plastifikuojančiu betono i̇maišu (SP) ir orą įtraukiančių ịmaišų (OIP) klasifikacija bei poveikis cemento hidratacijai, taip pat MWCNTs sąveika su SP ir OIP cemento tešlose. Taip pat pateikta informacija apie polistireninio putplasčio atliekų naudojimą statybinèse medžiagose. Skyriaus pabaigoje suformuluotos išvados ir patikslinti disertacijos uždaviniai.

Antrajame skyriuje aprašytos tyrimams naudotos medžiagos, parinktos formavimo mišinių sudètys, MWCNTs tirpalo, cementinès matricos ir lengvojo kompozito bandiniu formavimo būdai. Taip pat pristatytos tyrimų metodikos ir bandymams naudojama įranga.

Trečiajame skyriuje aprašyti MWCNTs tirpalo ir SP sąveikos su cemento tešla tyrimai. MWCNTs, SP ir OIP poveikis cemento tešloms bei sukietejjusio akmens savybėms, pateikti PPT ir PPN lengvųjų užpildų bei kompozicinès medžiagos fizikinių ir mechaninių savybių tyrimų rezultatai. Remiantis tyrimų rezultatais sukurta kompozicinè medžiaga, pasižyminti tokiomis savybèmis: tankis $420 \mathrm{~kg} / \mathrm{m}^{3}$, gniuždymo stipris $3,2 \mathrm{MPa}$, džiūstamasis traukumas $0,19 \mathrm{~mm} / \mathrm{m}$, šilumos laidumo koeficientas $0,116 \mathrm{~W} /(\mathrm{m} \cdot \mathrm{K})$, vandens garų varžos faktorius 15,8 .

Disertacijos tema paskelbti septyni straipsniai: trys Clarivate Analytics Web of Science duomenų bazès leidiniuose, turinčiuose citavimo rodikli, vienas Clarivate Analytics Web of Science duomenų bazès „Conference Proceedings“ leidiniuose, du kitų tarptautinių duomenų bazių leidiniuose ir vienas kitame recenzuojamame mokslo leidinyje. Disertacijos tema pristatyti penki pranešimai Lietuvos ir kitų šalių mokslinèse konferencijose. 


\section{Abstract}

The dissertation deals with the effect of carbon nanotubes (MWCNTs) and chemical admixtures (superplasticizers, air-entraining) on cement paste, hardened cement stone, as well as a cementitious composite with light aggregates (expanded polystyrene crushed waste (PPT) and milling waste (PPN) generated during production). The dissertation's primary goal is to create a cementitious lightweight composite with PPT and PPN filler waste, using a nano additive and effective chemical admixtures.

The dissertation consists of an introduction, three chapters, general conclusions, references, and lists of the author's publications on the dissertation topic, summary in English and three annexes.

The first chapter is devoted to the analysis of the literature. It provides information on the dispersion of MWCNTs, the influence of MWCNTs on the physical-mechanical properties of cement paste and hardened cement stone, the classification of chemical admixtures (superplasticizers (SP)) and airborne admixtures (IPs), and the effect on cement hydration, and the interaction of MWCNTs with SP and OIP in cement pastes. Information on the use of expanded polystyrene waste in construction materials is provided. At the end of the chapter, conclusions are formulated, and the tasks of the dissertation are specified.

The second chapter describes the materials used for the research, the moulding mixtures' selected compositions, moulding the MWCNTs solution, the cement matrix, and the lightweight composite samples. Test methodologies and test equipment are provided.

The third chapter describes the interaction of MWCNTs solution and SP with cement paste. Effects of MWCNTs, SP, and OIP on cement pastes and hardened stone properties, results of physical-mechanical properties of PPT and PPN lightweight aggregates, and composite material are presented. Based on the research results, a composite material with the following properties was developed: density $420 \mathrm{~kg} / \mathrm{m}^{3}$, compressive strength $3.2 \mathrm{MPa}$, drying shrinkage $0.19 \mathrm{~mm} / \mathrm{m}$, thermal conductivity coefficient $0.116 \mathrm{~W} /(\mathrm{m} \cdot \mathrm{K})$, water vapour resistance factor 15.8 .

Seven articles were published on the topic of the dissertation: three in the publications of the Clarivate Analytics Web of Science database with a citation index, one in the publications of the Clarivate Analytics Web of Science database in Conference Proceedings, two in other international databases, and one in other peer-reviewed scientific publications. Five papers on the topic of the dissertation were presented at the national and international scientific conferences. 


\section{Žymëjimai}

\section{Simboliai}

$l$ - testuojamo bandinio ilgis, $\mathrm{m}$;

$m_{i}$ - per laiko tarpą įmirkyto vandenyje bandinio masé, $\mathrm{kg}$;

$m_{0}$ - pradinè bandinio masé, $\mathrm{kg}$;

$P_{a}-$ atvirasis cemento akmens poringumas, $\%$;

$\rho_{w}$ - vandens tankis, $1000 \mathrm{~kg} / \mathrm{m}^{3}$;

$\rho_{c}$ - cemento akmens tankis, $\mathrm{kg} / \mathrm{m}^{3}$;

$\tau$ - signalo sklidimo laikas, $\mathrm{s}$;

$V$ - bandinio tūris, $\mathrm{m}^{3}$;

$W_{p}$ - visiškoji cemento akmens vandens sugertis, \%;

$W_{i}$ - vandens sugertis.

\section{Santrumpos}

$\mathrm{C}_{2} \mathrm{~S}\left(2 \mathrm{CaO} \cdot \mathrm{SiO}_{2}\right)$ - dikalcio silikatas (belitas);

$\mathrm{C}_{3} \mathrm{~A}\left(3 \mathrm{CaO} \cdot \mathrm{Al}_{2} \mathrm{O}_{3}\right)$ - trikalcio aliuminatas;

$\mathrm{C}_{3} \mathrm{~S}\left(3 \mathrm{CaO} \cdot \mathrm{SiO}_{2}\right)$ - trikalcio silikatas (alitas);

$\mathrm{C}_{4} \mathrm{AF}\left(4 \mathrm{CaO} \cdot \mathrm{Al}_{2} \mathrm{O}_{3} \mathrm{Fe}_{2} \mathrm{O}_{3}\right)$ - tetrakalcio aliumoferitas; 
$\mathrm{Ca}(\mathrm{OH})_{2}-$ kalcio hidroksidas (portlanditas);

$\mathrm{CSH}$ - kalcio hidrosilikatai.

DTA - diferencinè terminè analizė;

EC - elektrinis laidumas;

EXO - egzoterminè reakcija;

LS - modifikuoti lignosulfonatai;

MK - metakaolinas;

MS - maltas smèlis;

MWCNTs - daugiasienių anglies nanovamzdelių granulès „Graphistrength CW2-45“; OIP - orą įtraukianti įmaiša;

PAM - paviršiaus aktyvioji medžiaga;

PC - portlandcementis CEM I 42.5 R;

PCE - intetiniai polimerai, tokie kaip polikarboksilatai;

PCE-PA - akrilo kopolimerai;

PMS - polimelamino sulfonatai;

PNS - sulfoninti naftalenformaldehidai;

$\mathrm{PP}$ - polistireninis putplastis;

PPN - polistireninio putplasčio frezavimo nuopjovų atliekos;

PPT - trupinto polistireninio putplasčio taros atliekos;

SEM - skenuojančiosios elektroninès mikroskopijos analizė;

SP (A) - plastifikuojanti betono įmaiša lignosulfonatų pagrindu;

SP (B) - plastifikuojanti betono įmaiša polikarboksilatu pagrindu;

SP (C) - plastifikuojanti betono įmaiša modifikuotų akrilinių polimerų pagrindu;

$\mathrm{SP}$ - plastifikuojanti betono įmaiša;

$\mathrm{TG}$ - termogravimetrinè masès kitimo analizè;

UIG - ultragarso impulsų sklidimo greitis;

$\mathrm{V} / \mathrm{C}$ - vandens ir cemento santykis;

XRD - rentgenografinè analizè.

\section{Sąvokos}

Adsorbcija - ištirpusių arba dujinių medžiagų sugerimas kietojo arba skystojo kūno paviršiumi.

Aglomeracija - smulkių dalelių savybè sukibti tarpusavyje aplink stambesnę dalelę.

Cementinè matrica - cemento akmens ištisinè sudedamoji dalis visame kompozito tūryje, garantuojanti jo vienalytiškumą, fiksuojanti gaminio formą ir intarpų tarpusavio išsidèstymą bei tolygų apkrovos pasiskirstymą visame kompozite.

Cemento akmuo - sukietejusi cemento tešla.

viii 
Cemento tešla - dispersinè sistema, kurios kietoji fazė yra cemento dalelès, o terpé vanduo.

Cheminis susitraukimas - tūrio mažèjimas vykstant cemento hidratacijai.

Dispergavimas - kietosios medžiagos smulkinimas iki tam tikro dydžio dalelių ir išsklaidymas kurioje nors terpeje arba skysčio išpurškimas.

Dispersija - smulkių dalelių pasiskirstymas stambesnèse.

Džiūstamasis traukumas - tūrio mažèjimas iš medžiagos garuojant vandeniui.

Elektrinis laidumas - medžiagos savybė praleisti elektros srovę.

Flokuliacija - procesas, kai skystyje plūduriuojančios dalelès kaupiasi ị makroskopinę masę, dribsnius.

Hidratacija - cheminè vandens prijungimo prie mineralų reakcija.

Hidrofiliškumas - medžiagų savybė sąveikauti su vandens molekulėmis, tirpstant arba brinkstant vandenyje.

Hidrofobiškumas - medžiagų savybè atstumti vandenį.

Kapiliarinès sugerties koeficientas - medžiagos savybė sugerti vandenị; apskaičiuojamas kaip per tam tikrą laiką tarpą vandenị sugèrusios ir sausos medžiagos santykis.

Klampa - medžiagos savybė priešintis tekejjimui, t. y. vieno sluoksnio slinkimui kito sluoksnio atžvilgiu.

$\mathrm{pH}$ - vandenilio jonų $(\mathrm{H}+)$ koncentracijos tirpale matas, rodantis tirpalo rūgštingumą ar šarmingumą.

Poringumas - porų ir tuštumų skaičius medžiagoje.

Segregacija - dalelių išsiskirstymas mišinyje dèl jų dydžio, tankio, formos ar kitų skirtingų savybių.

Sklidumas - medžiagos gebèjimas tekèti.

Struktūrinio efektyvumo rodiklis - medžiagos gniuždymo stiprio ir tankio santykis.

Šilumos laidumo koeficientas - medžiagos savybė praleisti šilumą. Koeficientas parodo koks šilumos srautas $(W)$ pereina per $1 \mathrm{~m}$ storio ir $1 \mathrm{~m}^{2}$ ploto vienalytès medžiagos sienelę, kai temperatūros tarp šios sienelès priešingų paviršių skirtumas lygus $1 \mathrm{~K}$.

Tuštymètumas - bandinio tuštymių tūris.

Vandens garų pralaidumas - medžiagos savybė praleisti garus, t. y. kiek kartų drégminè varža yra didesnė už tokio pačio storio oro sluoksnio drègminę varžą, kuri lygi 1. 



\section{Turinys}

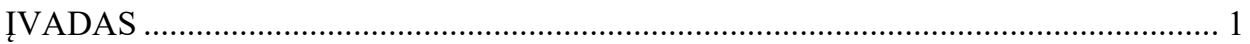

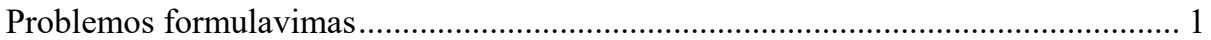

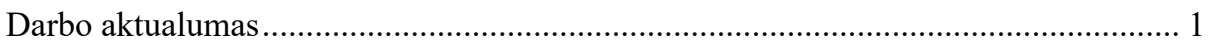

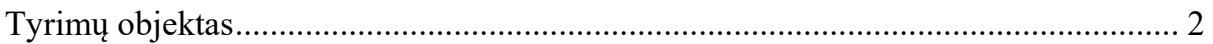

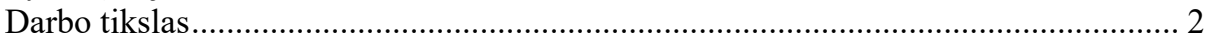

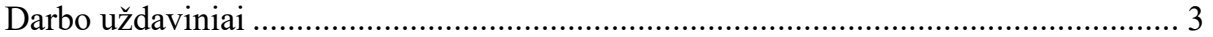

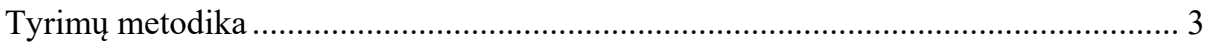

Darbo mokslinis naujumas ....................................................................................... 4

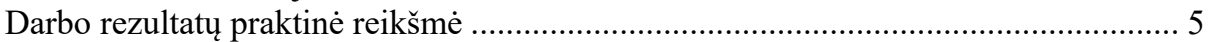

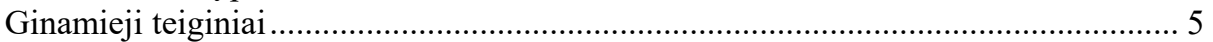

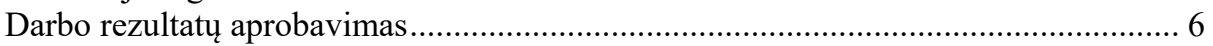

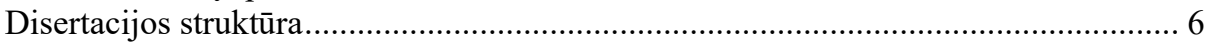

1. KOMPOZITŲ SU DAUGIASIENIAIS ANGLIES NANO VAMZDELIAIS, CHEMINĖMIS BETONO İMAIŠOMIS IR POLISTIRENINIO PUTPLASČIO ATLIEKOMIS TYRIMŲ APŽVALGA............................................................... 7

1.1. Anglies nanovamzdelių tipai ir charakteristikos.................................................. 8

1.2. Naudojamos plastifikuojančios betono įmaišos, jų klasifikacija

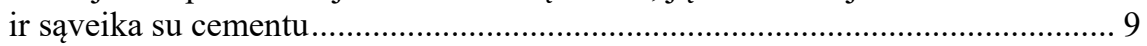

1.2.1. Plastifikuojančių betono įmaišų poveikis cemento hidratacijai ................. 13

1.2.2. Daugiasienių anglies nano vamzdelių dispergavimas................................... 16

1.2.3. Daugiasienių anglies nano vamzdelių sąveika su plastifikuojančiomis betono įmaišomis cemento tešlose ............................ 19 
1.2.4. Daugiasienių anglies nano vamzdelių poveikis cemento tešlos hidratacijai....

1.2.5. Daugiasienių anglies nano vamzdelių sąveika su orą įtraukiančiomis imaišomis cemento tešlose

1.3. Daugiasienių anglies nano vamzdelių poveikis cementinių medžiagų savybėms 24

1.3.1. Daugiasienių anglies nano vamzdelių poveikis cemento akmens stiprumo savybèms

1.3.2. Daugiasienių anglies nano vamzdelių poveikis cemento akmens mikrostruktūrai 27

1.3.3. Daugiasienių anglies nano vamzdelių poveikis cemento akmens džiūstamajam traukumui, ilgaamžiškumui ir šilumos laidumui ................ 28

1.4. Lengvieji cementiniai kompozitai su polistireninio putplasčio atliekomis.......... 30

1.5. Pirmojo skyriaus išvados ir disertacijos uždavinių formulavimas....................... 32

2. KOMPOZITUI SUKURTI NAUDOTOS MEDŽIAGOS IR TYRIMO METODAI . 35

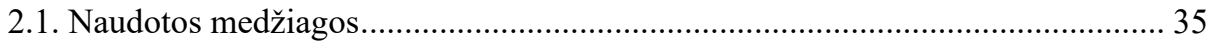

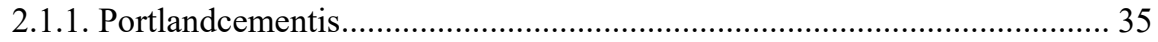

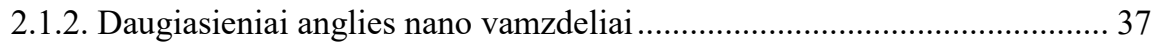

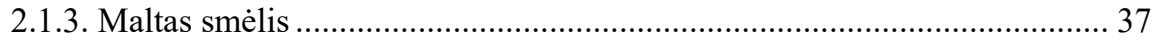

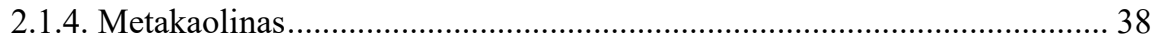

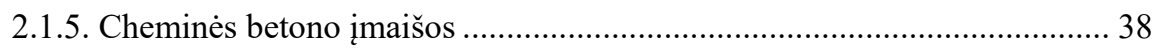

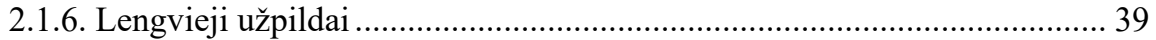

2.2. Daugiasienių anglies nano vamzdelių tirpalo, cemento tešlos ir lengvojo kompozito formavimo mišinių paruošimas bei bandinių formavimas................... 41

2.2.1. Daugiasienių anglies nano vamzdelių tirpalo paruošimas ........................... 41

2.2.2. Bandinių su cementu, daugiasieniais anglies nano vamzdeliais ir plastifikuojančiomis betono įmaišomis formavimas ............................... 42

2.2.3. Lengvojo kompozito formavimas ............................................................ 45

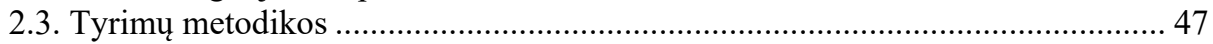

2.3.1. Kompozito komponentų tyrimo metodai ................................................... 47

2.3.2. Tirpalų ir cemento tešlos tyrimo metodai .................................................... 47

2.3.3. Sukietejusio cemento akmens tyrimai ........................................................ 48

2.3.4. Lengvojo kompozito bandinių tyrimo metodai......................................... 50

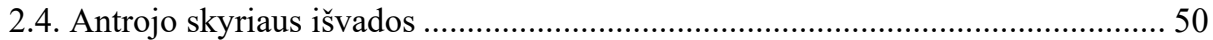

3. MODIFIKUOTŲ DAUGIASIENIAIS ANGLIES NANO VAMZDELIAIS IR CHEMINĖMIS BETONO İMAIŠOMIS CEMENTO TEŠLŲ, AKMENS IR LENGVOJO KOMPOZITO SU POLISTIRENINIO PUTPLASČIO ATLIEKOMIS

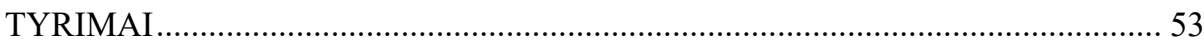

3.1. Daugiasienių anglies nano vamzdelių poveikio cemento tešlai

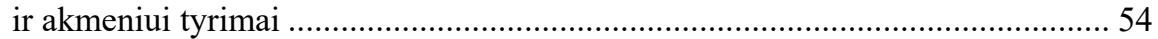

3.1.1. Daugiasienių anglies nano vamzdelių tirpalų tyrimai ................................5 54

3.1.2. Skenuojančiosios elektroninès mikroskopijos tyrimai................................. 55

3.1.3. Cemento tešlos dinamine klampa .......................................................... 56

3.1.4. Cemento tešlos elektrinis laidumas ir $\mathrm{pH}$................................................... 57 


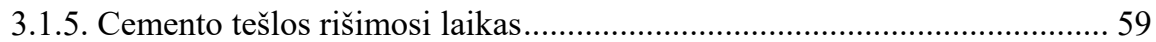

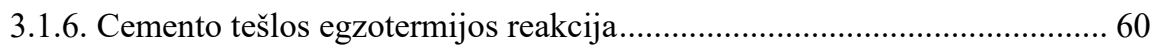

3.1.7. Cemento tešlos struktūros formavimasis .................................................... 61

3.1.8. Daugiasienių anglies nano vamzdelių poveikis cemento akmens

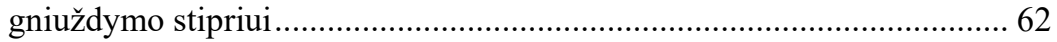

3.1.9. Daugiasienių anglies nano vamzdelių poveikis cemento akmens lenkimo stipriui

3.1.10. Daugiasienių anglies nano vamzdelių poveikis cemento akmens vandens sugerčiai.

3.2. Skirtingo tipo cheminių įmaišų poveikis cemento hidratacijai ir savybèms........ 66

3.2.1. Cheminių i̇maišų tirpalų pH ir elektrinis laidumas ...................................... 66

3.2.2. Cheminių įmaišų poveikis cemento tešlos sklidumui ................................. 68

3.2.3. Cheminiu įmaišų poveikis cemento tešlos dinaminei klampai ir temperatūrai

3.3. Cheminių įmaišų ir daugiasienių anglies nano vamzdelių poveikis cemento akmeniui .72

3.3.1. Cemento tešlų konduktometrijos tyrimai .................................................... 73

3.3.2. Cemento tešlų reologinių savybių tyrimai ................................................... 75

3.3.3. Cemento tešlų struktūros vystymasis......................................................... 77

3.3.4. Cemento tešlų hidratacijos procesų tyrimai ................................................ 78

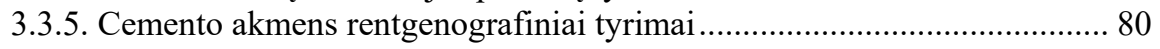

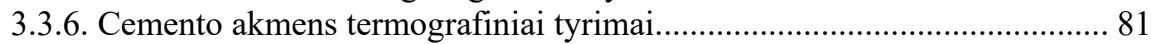

3.3.7. Cemento akmens mechaninių savybių tyrimai ........................................... 84

3.4. Daugiasienių anglies nano vamzdelių, plastifikuojančių betono įmaišų mišinio ir orą ịtraukiančios įmaišos poveikio cementinei matricai tyrimai ....................... 86

3.4.1. Cementinès matricos reologinès savybès.................................................. 86

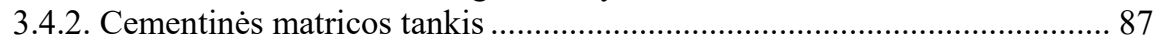

3.4.3. Cementinès matricos vandens sugertis ir poringumas .............................. 88

3.4.4. Cementinès matricos makro- ir mikrostruktūrai tyrimai.............................. 90

3.4.5. Cementinès matricos gniuždymo stiprio tyrimai ...................................... 92

3.4.6. Cementinès matricos struktūrinio efektyvumo rodiklis ............................... 94

3.4.7. Cementinès matricos struktūros formavimosi tyrimai ................................... 95

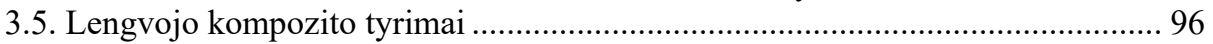

3.5.1. Kompozito makrostruktūros ir mikrostruktūros tyrimai ............................. 96

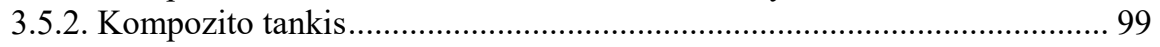

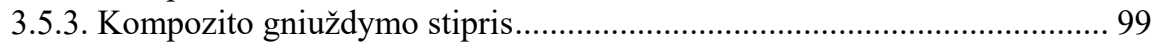

3.5.4. Kompozito struktūrinio efektyvumo rodiklis........................................... 101

3.5.5. Kompozito ultragarso impulso sklidimo greičio tyrimai ........................... 102

3.5.6. Kompozito šilumos laidumo koeficientas................................................... 104

3.5.7. Kompozito kapiliarinès sugerties koeficientas ......................................... 105

3.5.8. Kompozito vandens garų pralaidumas................................................... 106

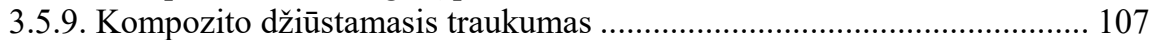

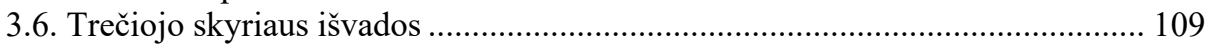

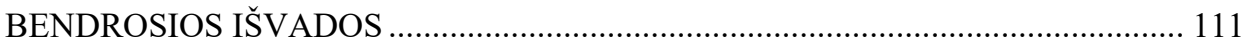


LITERATŪRA IR ŠALTINIAI

AUTORIAUS MOKSLINIŲ PUBLIKACIJŲ DISERTACIJOS TEMA SĄRAŠAS . 133

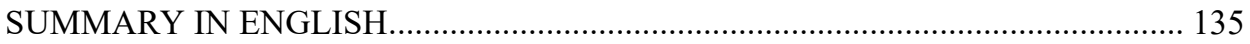

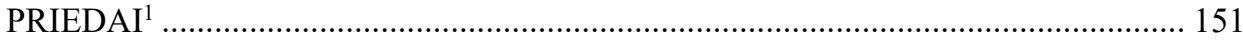

A priedas. Autoriaus sąžiningumo deklaracija ........................................................ 153

B priedas. Bendraautorių sutikimai teikti publikacijose skelbtą medžiagą daktaro

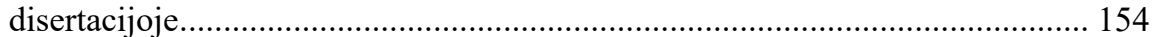

C priedas. Autoriaus mokslinių publikacijų disertacijos tema kopijos...................... 161

${ }^{1}$ Priedai pateikiami pridètoje kompaktinejje plokštelèje. 


\section{Contents}

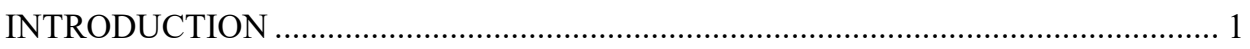

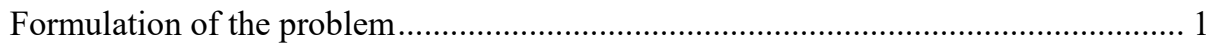

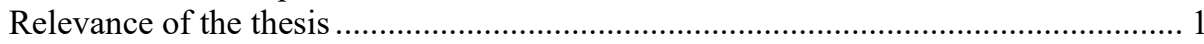

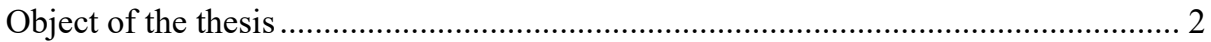

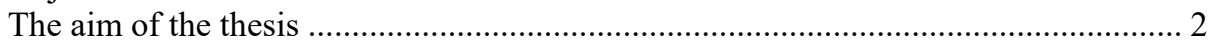

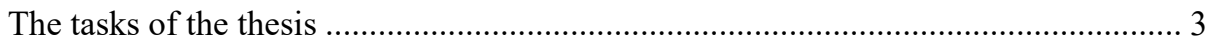

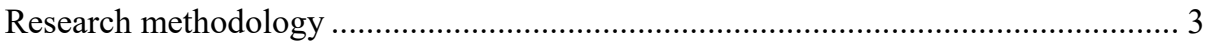

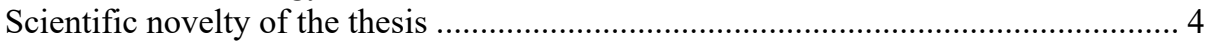

Practical value of the research findings ................................................................. 5

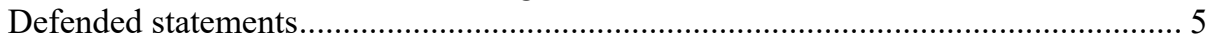

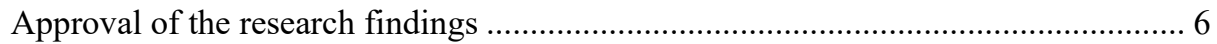

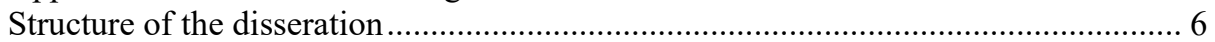

1. RESEARCH ANALYSIS OF COMPOSITE MATERIALS WITH MULTIWALLED CARBON NANOTUBES, CHEMICAL ADDITVES AND

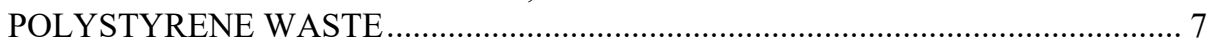

1.1. Types and characteristics of carbon nanotubes................................................... 8

1.2. Used superplasticizers, their classification and interaction with cement............... 9

1.2.1. Effects of plasticizers on cement hydration ............................................... 13

1.2.2. Dispersion of multi-walled carbon nanotubes .......................................... 16

1.2.3. Interaction of multi-walled carbon nanotubes with superplasticizers in

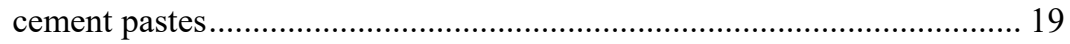


1.2.4. Effects of multi-walled carbon nanotubes on cement paste hydration....... 21

1.2.5. Interaction of multi-walled carbon nanotubes with air-entrainer admixtures in cement pastes

1.3. Effect of multi- walled carbon nanotubes on the properties of cementitious materials

1.3.1. Effects of multi-walled carbon nanotubes on the strength properties of cement stone

1.3.2. Effects of multi-walled carbon nanotubes on cement microstructure of cement stone

1.3.3. Effects of multi-walled carbon nanotubes on drying shrinkage, durability and thermal conductivity of cement stone.

1.4. Lightweight cement composites with polystyrene foam waste ......................... 30

1.5. Conclusions of the first chapter and formulation of the dissertation tasks ......... 32

2. MATERIALS USED FOR THE COMPOSITE AND RESEARCH METHODS ...... 35

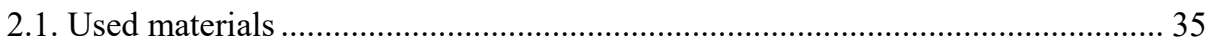

2.1.1. Portland cement ................................................................................ 35

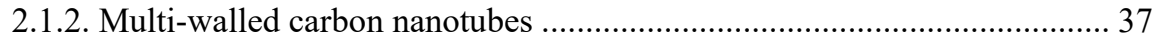

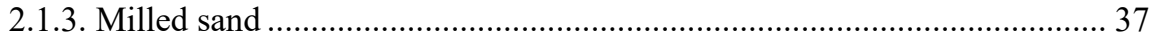

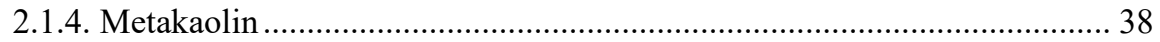

2.1.5. Superplasticizers and air-entrainer.................................................... 38

2.1.6. Lightweight aggregates................................................................... 39

2.2. Moulding of multi-walled carbon nanotubes solution, cement paste, and

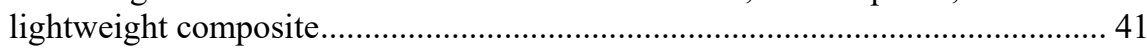

2.2.1. Preparation of multi-walled carbon nanotubes solution.......................... 41

2.2.2. Moulding of samples with cement, multi- walled carbon nanotubes and

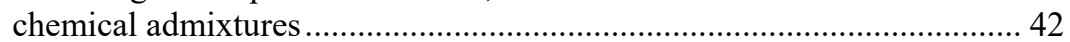

2.2.3. Moulding of composite ....................................................................... 45

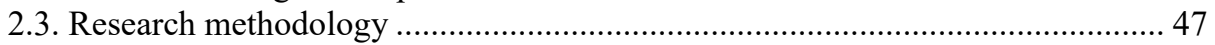

2.3.1. Research methods of composite materials ............................................. 47

2.3.2. Research methods of solutions and cement pastes................................ 47

2.3.3. Research methods of hardened cement stone .......................................... 48

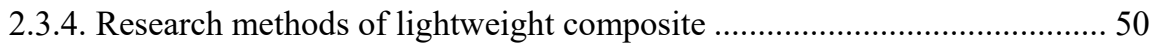

2.4. Conclusions of the second chapter ...................................................................... 50

3. RESEARCH OF CEMENT PASTES, STONE AND LIGHTWEIGHT COMPOSITE WITH POLYSTYRENE FOAM WASTE, MODIFIED BY MULTI-WALLED CARBON NANOTUBES AND CHEMICAL ADMIXTURES ............................... 53

3.1. Effects of multi-walled carbon nanotubes on cement pastes and hardened cement stone.

3.1.1. Multi-walled carbon nanotubes solution................................................ 54

3.1.2. Scanning electron microscopy of multi-walled carbon nanotubes solution

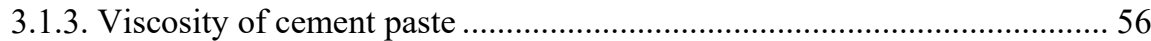

3.1.4. Electrical conductivity and $\mathrm{pH}$ of cement paste..................................... 57 


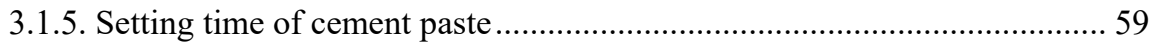

3.1.6. Exothermic reaction temperatures of cement paste .................................... 60

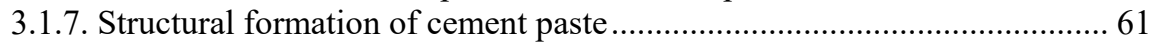

3.1.8. Effects of multi-walled carbon nanotubes on cement stone compressive strenght

3.1.9. Effects of multi-walled carbon nanotubes on cement stone flexular strenght

3.1.10. Effects of multi-walled carbon nanotubes on cement stone water absorption 64

3.2. Influence of plasticizers on cement stone hydration and properties ..................... 66

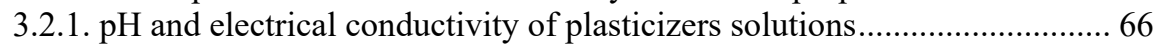

3.2.2. Influence of plasticizers on cement paste spread area ................................ 68

3.2.3. Influence of plasticizers on cement paste viscosity and temperature......... 69

3.3. Influence of plasticizers and multi-walled carbon nanotubes on

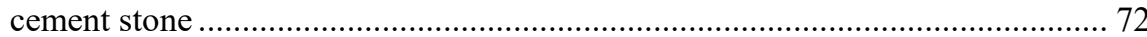

3.3.1. Electrical conductivity of cement paste ………........................................ 73

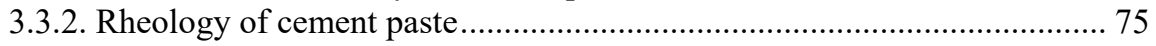

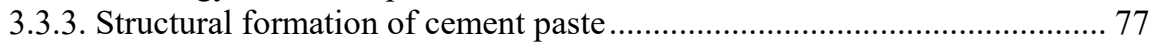

3.3.4. Exothermic reaction temperatures of cement paste ……………................ 78

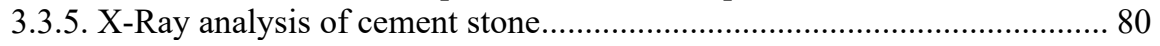

3.3.6. Differential thermal analysis analysis of cement stone............................... 81

3.3.7. Mechanical properties of cement stone....................................................... 84

3.4. Influence of multi-walled carbon nanotubes, plasticizers and

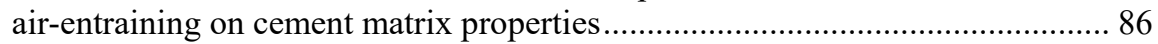

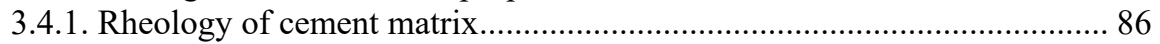

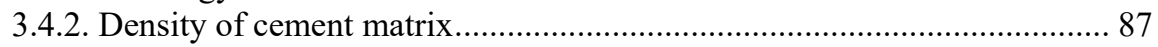

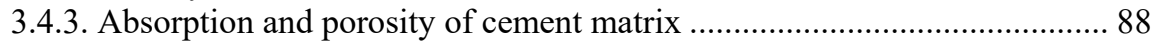

3.4.4. Macro- and microstructure of cement matrix ........................................... 90

3.4.5. Compressive strenght of cement matrix ................................................... 92

3.4.6. Structural efficiency of cement matrix ....................................................... 94

3.4.7. Structural formation of cement matrix........................................................ 95

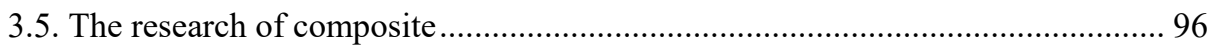

3.5.1. The macrostructure and microstructure of composite................................ 96

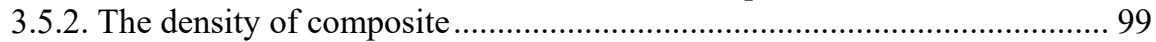

3.5.3. The compressive strenght of composite..................................................... 99

3.5.4. The structural efficiency of composite ...................................................... 101

3.5.5. The ultrasound pulse velocity of composite ............................................ 102

3.5.6. The thermal conductivity of composite ................................................... 104

3.5.7. The water absorbtion by capillarity of composite.................................... 105

3.5.8. The water vapour diffusion resistance factor of composite ....................... 106

3.5.9. The drying shrinkage of composite...................................................... 107

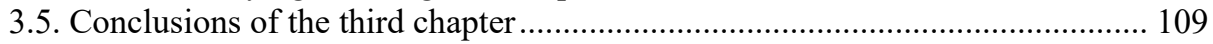

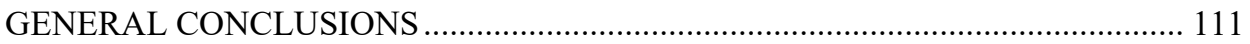




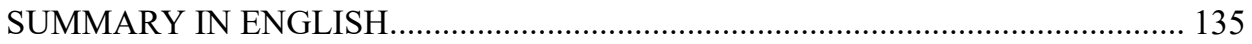

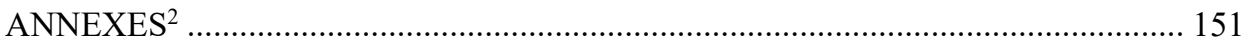

Annex A. Authors' declaration of academic integrity ........................................... 153

Annex B. The co-authors' agreements for providing the material of the joint publications in the thesis......

Annex C. Copies of the scientific publications by the author on the topic of the dissertation.

${ }^{2}$ The annexes are supplied in the enclosed compact disc. 


\section{Ivadas}

\section{Problemos formulavimas}

Polistireninio putplasčio atliekos yra hidrofobinès ir lengvos (jų tankis - 12$\left.20 \mathrm{~kg} / \mathrm{m}^{3}\right)$, jų pagrindu pagaminti kompozitai pasižymi nevienalytiškumu, atliekos netolygiai pasiskirsto cementinès matricos tūryje, blogai sukimba su cementine matrica ir todèl kompozitu gniuždymo stiprio vertès žemos. Polistireninio putplasčio atliekų tolygaus pasiskirstymo cemento tešlos tūryje problemai spręsti gali būti naudojamos orą įtraukiančios įmaišos, kurios sumažina šių atliekų hidrofobiškumą ir pagerina pasiskirstymą cemento tešloje. Polistireninio putplasčio atliekų sukibčiai su cemento akmeniu gerinti ir paties cemento akmens mechaninèms savybèms stiprinti gali būti panaudoti nanopriedai ir efektyvios plastifikuojančios betono įmaišos, tačiau neaišku, kaip tokių priedų derinys gali paveikti lengvojo kompozito struktūrą ir eksploatacines savybes.

\section{Darbo aktualumas}

Visame pasaulyje polistireninio putplasčio produktai labai gausiai naudojami kaip pakuotès, indai ir panašiai, tačiau vieną kartą panaudoti visi šie gaminiai išmetami 
ir tampa atliekomis. $95 \%$ polistireninio putplasčio sudaro oras, todèl sąvartynuose nuolat augantys polistireninio putplasčio taros atliekų kiekiai užima didelius plotus ir tūrius ir praktiškai nesuyra. Mechaniškai frezuojant polistireninio putplasčio plokštes, susidaro kita polistireninio putplasčio atliekų rūšis - frezavimo nuopjovų atliekos, kurios surenkamos ị filtrus. Polistireninio putplasčio taros ir frezavimo nuopjovu (PPN) atliekų perdirbimo ar pakartotinio naudojimo galimybės yra perspektyvios, tačiau iki šiol nèra pakankamai ištirtos. Viena iš tokių galimybių - sutrupinti polistireninio putplasčio taros atliekas (PPT) ir gautas granules kartu su frezavimo nupjovų atliekomis (PPN) panaudoti cementiniams kompozitams kurti.

Dauguma iki šiol atliktų polistireninio putplasčio atliekų naudojimo statybinèse medžiagose tyrimų buvo skirti polistireninio putplasčio atliekų utilizavimo problemoms spręsti. Ištirtų kompozicinių medžiagų stipris buvo mažas, todèl jų naudojimo sritis yra labai siaura. Tokių kompozicinių medžiagų naudojimo sritis reikia išplèsti, o tam būtina gerinti paties kompozito eksploatacines savybes.

Šiame darbe abiejų atliekų naudojimas lengviesiems cementiniams kompozitams kurti siejamas ne tik su atliekų gyvavimo ciklo užbaigimu, bet ir su kompozito savybiu gerinimu, t. y. keičiant užpildų tarpusavio santyki gauti skirtingų savybių kompozitus, taip praplečiant jų naudojimo galimybes (pvz., mažaaukščių pastatų išorinèse ir vidinèse atitvarose, pakeičiant energijai imlias lengvąsias medžiagas). Sukurto kompozito eksploatacinès savybės yra analogiškos arba geresnès, nei akytojo betono gaminių savybès. Šiam tikslui planuojama panaudoti, kompozito struktūrą modifikuojančius priedus, taip pat ir nano dydžio.

\section{Tyrimu objektas}

Darbo tyrimų objektas - cementinis kompozitas, susidedantis iš mišrių atliekų užpildo, cemento akmens, modifikuoto daugiasieniais anglies nano amzdeliais (MWCNTs), plastifikuojančių betono įmaišų, orą įtraukiančios įmaišos (OIP) ir metakaolino priedo.

\section{Darbo tikslas}

Disertacijos tikslas - sukurti cementinị kompozitą su polistireninio putplasčio technologinèmis atliekomis, naudojant chemines betono ịmaišas bei daugiasienius anglies nano vamzdelius. 


\section{Darbo uždaviniai}

Darbo tikslui pasiekti darbe reikia spręsti šiuos uždavinius:

1. Nustatyti daugiasieniu anglies nano vamzdeliu priedo kiekio poveiki cemento akmens struktūrai bei mechaninėms savybėms ir, remiantis gautais rezultatais, parinkti geriausias mechanines savybes ir struktūrą užtikrinantị daugiasienių anglies nano vamzdelių kiekį.

2. Ištirti daugiasienių anglies nano vamzdelių ir skirtingų cheminių betono įmaišų poveikį, cemento tešlų reologinėms savybėms, cemento hidratacijai, sukietejusio cemento akmens fizikinėms ir mechaninėms savybėms bei struktūrai ir parinkti geriausias mechanines savybes ir struktūrą užtikrinančias chemines betono įmaišas.

3. Ištirti orą įtraukiančios įmaišos ir daugiasienių anglies nano vamzdelių poveiki cemento akmens fizikinėms ir mechaninèms savybėms bei struktūrai. Išsiaiškinti cementinę matricą modifikuojančių priedų veikimo cemento tešloje ypatumus.

4. Sukurti cementinị kompozitą iš modifikuotos daugiasieniais anglies nano vamzdeliais ir cheminèmis betono įmaišomis cementinès matricos su lengvaisiais trupinto ir frezuoto polistireninio putplasčio atliekų užpildais, ir patikrinti sukurto kompozito atitikimą eksploatacinių savybių reikalavimams.

\section{Tyrimų metodika}

Daugiasienių anglies nano vamzdelių, cheminių betono įmaišų tirpalų ir cemento tešlų tyrimams buvo taikyti konduktometrijos, $\mathrm{pH}$, dinaminès klampos, rišimosi trukmès bei ultragarsinès analizès metodai. Cemento tešlos egzoterminio efekto temperatūros matavimai atlikti pagal „Alcoa“ firmos sukurtą metodiką. Cemento akmens struktūros tyrimams buvo taikyti skenuojančiosios elektroninès mikroskopijos (SEM), rentgenografinès, terminès analizès, porometrijos ir ultragarsinès analizès metodai. Cemento akmens bei lengvojo kompozito fizikinès ir mechaninès savybès buvo tiriamos standartiniais tyrimų metodais, taikomais tankiui, lenkimo stipriui, gniuždymo stipriui, šilumos laidumo koeficientui, kapiliarinei vandens sugerčiai, ilgalaikei vandens sugerčiai, pralaidumui vandens garams ir džiūstamajam traukumui nustatyti. Vertinant eksperimentų duomenis, buvo taikomi loginès analizès ir sintezès metodai. Gautų eksperimentinių tyrimų duomenų analizè atlikta taikant matematinius statistinius metodus, kurių metu ịvertinti gautų verčių nuokrypiai. 


\section{Darbo mokslinis naujumas}

Rengiant disertaciją buvo gauti šie medžiagų inžinerijos mokslui nauji rezultatai:

1. Nustatytas cemento akmens gniuždymo stiprị labiausiai didinantis $(0,005 \%$ nuo cemento masès) daugiasienių anglies nano vamzdelių priedo kiekis. Nustatytas daugiasienių anglies nano vamzdelių ir plastifikuojančių betono įmaišų mišinio (poliakrilato ir polikarboksilato) poveikis cemento hidratacijai, naujadarų susidarymo procesui ir cemento akmens struktūros formavimuisi. Gautos naujos žinios leidžia sukurti $25 \%$ didesnio gniuždymo stiprio cemento akmenį, lyginant su cemento akmens be priedo gniuždymo stipriu.

2. Nustatyta, kad dèl daugiasienių anglies nano vamzdelių, plastifikuojančių betono ịmaišų (poliakrilato ir polikarboksilato) mišinio ir orą įtraukiančios įmaišos sąveikos cemento tešloje pasikeičia cemento akmens poringoji struktūra, didèja gniuždymo stipris ir mažèja tankis. Gautos naujos žinios leidžia sukurti mažesnio tankio lengvaji kompozitą neprarandant jo stiprumo savybių.

3. Nustatyta, kad dèl daugiasienių anglies nano vamzdelių sąveikos su plastifikuojančių betono įmaišų (poliakrilato ir polikarboksilato) mišiniu, ir orą ịtraukiančia ịmaiša kompozito su polistireninio putplasčio atliekų užpildų tankis mažeja, o gniuždymo stipris didèja. Kompozituose su daugiasienių anglies nano vamzdelių priedu $(0,005 \%$ nuo cemento kiekio), gautos tankio reikšmès yra nuo 7 iki $21 \%$ mažesnès, o stiprio reikšmės nuo 3 iki 33 \% aukštesnès nei analogiškuose kompozituose be daugiasienių anglies nano vamzdelių priedo.

4. Trupinto ir frezuoto polistireninio putplasčio santykis $2 / 2$ kompozito sudètyje su daugiasienių anglies nano vamzdelių priedu leidžia pasiekti analogiškas arba geresnes nei akytojo betono fizikines ir mechanines savybes, kai kompozito tankis siekia $420 \mathrm{~kg} / \mathrm{m}^{3}$, o gniuždymo stipris 3,2 MPa.

5. Gautos naujos žinios apie teigiamą daugiasieniu anglies nano vamzdelių poveikį kompozitų su plastifikuojančių betono įmaišų mišiniu ir orą įtraukiančia ịmaiša fizikinèms ir mechaninèms savybėms leidžia projektuoti ne tik lengvuosius, bet ir labai lengvus cementinius kompozitus su pagerintomis eksploatacinèmis savybėmis. 


\section{Darbo rezultatų praktinè reikšmè}

Lengvojo kompozito gamyboje naudojant trupinto polistireninio putplasčio ir frezuoto polistireninio putplasčio atliekas, sprendžiama didžiulio šiu atliekų kiekio pakartotinio naudojimo problema pagal žiedinès ekonomikos principus.

Abiejų atliekų naudojimas lengviesiems cementiniams kompozitams kurti siejamas ne tik su atliekų gyvavimo ciklo užbaigimu, bet ir su naujų mažiau energijai imlių statybinių kompozitų kūrimu, jų savybių gerinimu bei sukurtų kompozitų naudojimo galimybių praplètimo statybų procesuose, keičiant tradicines energijai imlias lengvąsias (pvz., keramzito pagrindu arba autoklavinio akytojo betono) statybines medžiagas. Sukurto kompozito eksploatacinès savybės yra analogiškos arba geresnès, nei akytojo betono gaminių, todèl sukurtas kompozitas gali būti naudojamas kaip alternatyva autoklaviniam akytajam betonui.

Lengvasis kompozitas gali būti naudojamas mažaaukščiu pastatų išorinėse ir vidinėse atitvarose kaip laikančio karkaso elementas, suteikiantis papildomą apšildymą.

Šio lengvojo kompozito savybes galima lengvai reguliuoti gamybos metu. Taip sudaroma unikali galimybė lauko atitvaras projektuoti iš vientisos medžiagos, kai didesni gniuždymo stiprị turintys dirbiniai naudojami kartu su žemesnių stiprumo verčiu, bet geresnes šilumos izoliacijos savybes turinčiais elementais.

\section{Ginamieji teiginiai}

1. Kartu su poliakrilato ir polikarboksilato plastifikuojančiu betono įmaišų mišiniu daugiasienių anglies nano vamzdelių priedo kiekis $(0,005 \%$ nuo cemento masès) didina hidratacijos produktų kiekị ir leidžia pasiekti $25 \%$ didesnị cemento akmens gniuždymo stiprị.

2. Daugiasienių anglies nano vamzdelių priedas kartu su poliakrilatų ir polikarboksilatų plastifikuojančių betono įmaišų mišiniu bei orą įtraukiančia ịmaiša, keičia cemento akmens struktūrą, pasižymi armuojančiu poveikiu cemento akmeniui, taip didindamas cemento akmens mechanines savybes, padidèjus atviram medžiagos poringumui.

3. Daugiasienių anglies nano vamzdelių priedas leidžia pasiekti aukštesnes gniuždymo stiprio ir mažesnes tankio vertes kompozituose su trupinto ir frezuoto polistireninio putplasčio atliekų užpildais, lyginant su analogiškais kompozitais be daugiasienių anglies nano vamzdelių priedo. Sukurto kompozito eksploatacinès savybès yra analogiškos arba geresnès negu autoklavinio akytojo betono. 


\section{Darbo rezultatų aprobavimas}

Disertacijos tema paskelbti septyni straipsniai: trys Clarivate Analytics Web of Science duomenų bazès leidiniuose, turinčiuose citavimo rodiklị (Leonavičius et al., 2018, 2019c, 2020), vienas Clarivate Analytics Web of Science duomenu bazès „Conference Proceedings“ leidiniuose (Leonavičius et al., 2017), du kitų tarptautinių duomenų bazių leidiniuose (Leonavičius et al., 2019a, 2019d), vienas kituose recenzuojamuose mokslo leidiniuose (Leonavicius et al., 2019b).

Disertacijoje atliktų tyrimų rezultatai buvo pristatyti paskelbti penkiose mokslinėse konferencijose Lietuvoje ir užsienyje:

- Tarptautinejje konferencijoje "Modern Materials and Manufacturing 2019” (MMM 2019) 2019 m., Taline;

- Tarptautineje konferencijoje "Innovative Materials, Structures and Technologies 2019” (IMST 2019) 2019 m. Rygoje;

- Tarptautineje konferencijoje "13rd International Conference "Modern Building Materials, Structures and Techniques" (MBMST 2019) 2019 m. Vilniuje;

- Tarptautineje konferencijoje "Innovative Materials, Structures and Technologies 2017" (IMST 2017) 2017 m. Rygoje;

- 23-joje jaunujų mokslininkų konferencijoje „Mokslas - Lietuvos ateitis“ $2016 \mathrm{~m}$. Vilniuje.

\section{Disertacijos struktūra}

Disertaciją sudaro įvadas, trys skyriai ir bendrosios išvados. Taip pat yra trys priedai.

Darbo apimtis - 151 puslapis, neskaitant priedų, tekste panaudotos 3 numeruotos formulès, 67 paveikslai ir 14 lentelių. Rašant disertaciją buvo panaudoti 196 literatūros šaltiniai. 


\section{1}

\section{Kompozitų su daugiasieniais anglies nano vamzdeliais, cheminèmis betono įmaišomis ir polistireninio putplasčio atliekomis tyrimų apžvalga}

Šiame skyriuje aptariama bendra informacija apie MWCNTs dispergavimą, MWCNTs įtaką cemento tešlos ir sukietejjusio akmens fizikinèms ir mechaninėms savybėms, plastifikuojančių betono įmaišų klasifikaciją ir poveikị cemento hidratacijai, MWCNTs sąveiką su plastifikuojančiomis betono įmaišomis ir OIP cemento tešlose. Taip pat išnagrinèti jau atlikti kompozicinių medžiagų su polistireninio putplasčio (PP) atliekomis tyrimai.

Skyriaus tematika paskelbti septyni autoriaus straipsniai (Leonavičius et al., 2017, 2018, 2019a, 2019b, 2019c, 2019d, 2020). 


\subsection{Anglies nanovamzdelių tipai ir charakteristikos}

Anglies nanovamzdeliai yra tam tikra anglies forma. Anglies nanovamzdeliai pirmą kartą buvo atrasti $1952 \mathrm{~m}$. Rusijoje, tačiau pramonejje jie nebuvo naudojami iki 1991 m., kol Japonijos Fundamentinių tyrimų laboratorijoje NEC buvo iš naujo atrasti kaip šalutinis fulereno (vien iš anglies atomų susidedanti molekulè) sintezès produktas (Iijima, 1991). Sukurta daugybè būdų, kaip susukti grafito plokštelę vamzdeliui gauti. Oagal gavimo būdus jie skirstomi ị formas: zigzago, chiralinès (asimetrinès) ir krèslo (Esawi \& Farag, 2007). Anglies nanovamzdeliai sudaryti iš vieno vienasienio (angl. single-walled) anglies atomų sluoksnio (1.1 pav. a) arba iš kelių vienas kitame esančių vienasienių sluoksnių, jau vadinamų daugiasieniais anglies nanovamzdeliais (1.1 pav. b). MWCNTs skersmuo gali būti iki $100 \mathrm{~nm}$.

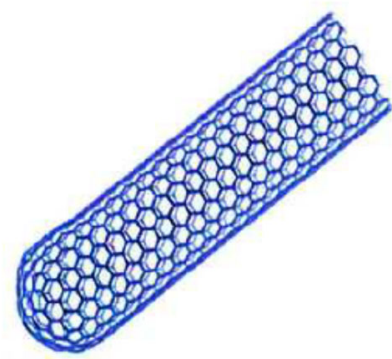

a)

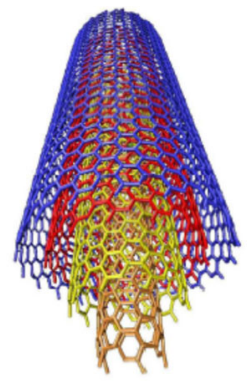

b)

1.1 pav. Anglies nanovamzdelio vaizdas: a) vienasienio; b) daugiasienio (Bordere et al., 2011)

Fig. 1.1. Carbon nanotube: a) single walled; b) multi-wall (Bordere et al., 2011)

Vienasienių nanovamzdelių skersmuo yra $1-10 \mathrm{~nm}$, daugiasienių (MWCNTs) - 5-100 nm, nes jų struktūrą sudaro daugybė koncentrinių cilindrų, sukibusių dèl van der Waalso jègų (He et al., 2005). MWCNTs paviršiaus plotas dažniausiai yra nuo $100000 \mathrm{iki} 700000 \mathrm{~m}^{2} / \mathrm{kg}$ (Peigney et al., 2001). MWCNTs paprastai išlaiko tarpus tarp apvalkalų, artimus grafito tarpsluoksnių $0,335 \mathrm{~nm}$ atstumams (Lavin, et al., 2002).

Vienasieniai nanovamzdeliai yra mažiau veiksmingi nei MWCNTs. Daugiasluoksnė MWCNTs struktūra yra tvirtesnè nei vienasienių, ypač gniuždant. Kitas MWCNTs pranašumas, palyginti su vienasieniais, yra tas, kad didelio masto sintezę galima lengvai pasiekti atlikus kelis cheminio garų nusodinimo metodo patobulinimus (Bandow et al., 2002). Verta paminèti, kad MWCNTs yra pigesni ir lengviau prieinami nei vienasieniai. MWCNTs yra laikoma viena iš perspektyviausių XXI a. medžiagų, kurias naudojant kuriamos naujos, cemento pagrindu 
pagamintos, struktūriškai vientisos medžiagos (Harrison \& Atala, 2007; Liu et al., 2005; Mollah et al., 2000).

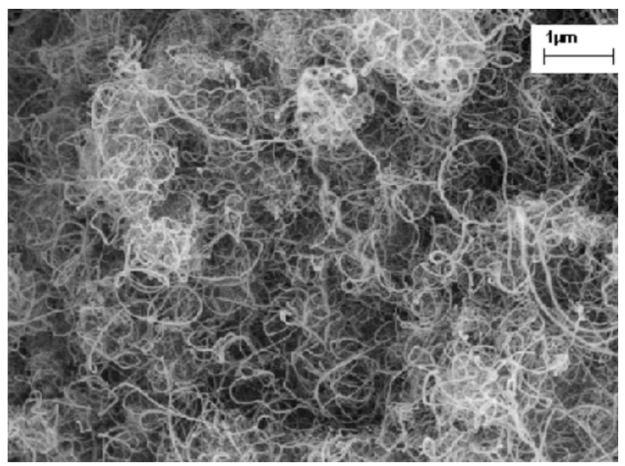

1.2 pav. Disperguotų anglies nanovamzdelių skenuojančiosios elektroninès mikroskopijos vaizdas (didinimas $-\times 30000$ ) (Bordere et al., 2011)

Fig. 1.2. Scanning electron microscopy view of dispersed carbon nanotubes (magnification $-\times 30000)$ (Bordere et al., 2011)

Tyrëjus sudomino aukštos MWCNTs gniuždymo ir tempimo stiprio, šiluminès bei unikalios elektrinès ir cheminès savybès (Ajayan, 1999; Cwirzen et al., 2009; Li et al., 2005; Liu et al., 2005; Srivastava et al., 2003; Yakovlev et al., 2006). Cementinių medžiagų savybèms įtakos taip pat turi MWCNTs gamybos metodai ir formos (granulès (1.2 pav.), tirpalai ar milteliai).

Norint MWCNTs naudoti cementinèse medžiagose, labai svarbu, kad MWCNTs tolygiai pasiskirstytų vandeniniame tirpale ir cemento tešloje. Tačiau MWCNTs yra hidrofobiniai ir jų pasiskirstymui turi būti naudojamos plastifikuojančios betono įmaišos, kurios paprastai naudojamos cementinèse medžiagose, bei kitos paviršiaus aktyviosios medžiagos (PAM) (Collins et al., 2012; Parveen et al., 2015; Yu et al., 2007; Zou et al., 2015).

\subsection{Naudojamos plastifikuojančios betono įmaišos, jų klasifikacija ir sąveika su cementu}

Šiandieninių cementinių kompozicinių medžiagų kūrimas neįsivaizduojamas be įvairių cheminių įmaišų, tokių kaip plastifikuojančios betono įmaišos (SP), kurios, nekeičiant mišinio konsistencijos, leidžia gerokai sumažinti vandens kiekị betone, arba, nemažindamos vandens, ženkliai padidina betono slankumą arba paveikia abu rezultatus vienu metu. SP apibendrintai vadinamos reologijos modifikatoriais, dažniausiai vandenyje turi neigiamaji krūvị, anijoninių ryšių ir dèl šių savo cha- 
rakteristikų gerina betono sklidumą. Kai kurios SP taip pat turi didelę ịtaką cemento hidratacijai, betono tankiui ir poringumui bei stiprumo charakteristikoms. Cementinèse medžiagose SP ima veikti rišimosi metu arba kietejant (Houst et al., 2008; Kashcheev et al., 2011; Mangane et al., 2018a; Simon et al., 2011; Yang et al., 2018; Ушеров-Маршак, 2005).

Dabartiniu metu naudojamos SP yra organinès medžiagos, kurios pagal cheminę sudètį gali būti skirstomos ị šias grupes:

- modifikuoti lignosulfonatai (LS), turintys ribotą vandens kiekio mažinimo gebą - apie 8-10 \%, naudojami mišinių klojumui pagerinti;

- sulfoninti naftalenformaldehidai (PNS), turintys gebą sumažinti vandens kiekị iki $30 \%$;

- polimelamino sulfonatai (PMS), gebantys sumažinti vandens kiekį iki 20-30\%;

- sintetiniai polimerai, tokie kaip polikarboksilatai (PCE) ir akrilo kopolimerai (PCE-PA), turi universalią cheminę struktūrą ir gali sumažinti vandens kiekị iki 40 \% (Björnström \& Chandra, 2003; Kovler \& Roussel, 2011; Wang et al., 2018a; Ушеров-Маршак, 2005).

PCE turi i šukas panašią struktūrą. Paprastai pagrindinị molekulès kamieną sudaro poli(akrilo rūgšties--akrilo esteriu) grandis, o šonines grandines sudaro polietileno oksidas (PEO) (Tian et al., 2019). Pagrindiniai veiksniai, lemiantys PCE eksploatacines savybes, pateikti 1.3 paveiksle (Marchon et al., 2016; Wang et al., 2018b):

- pagrindinès molekulès kamieno ilgis;

- pagrindinès molekulès (kamieno) cheminè prigimtis (akrilo, metakrilo, maleino ir kt.);

- šoninių grandinių ilgis;

- šoninių grandinių cheminè prigimtis (PEG, polipropileno oksidas, ir kt.);

- šoninių grandinių pasiskirstymas išilgai kamieno (atsitiktinis, laipsniškas);

- anijoninis krūvio tankis;

- ryšys tarp kamieno funkcinių grupių ir šoninès grandies funkcinių grupių (esteris, eteris, amidas ir t. t.).

SP veikimas grindžiamas vandens ir disperguotų cemento dalelių sistemos tarpusavio traukos bei atstūmimo jègų tarp dalelių pakeitimu. Šis mechanizmas iki galo nèra išaiškintas. Skirtingai nuo naudojamų SP, minimi elektrostatiniai, steriniai (erdviniai), entropiniai ir kapiliariniai efektai arba jų deriniai (Plank et al., 2009; Wang et al., 2018a). Iprastos SP, tokios kaip PNS, PMS arba LS pagrindu yra anijoninès paviršiaus aktyviosios medžiagos, tačiau jų molekulinė masė (atitinkamai 6028, 2851 ir $1269 \mathrm{~g} / \mathrm{mol})$ yra gerokai mažesnè nei PCE (12 000$8000 \mathrm{~g} / \mathrm{mol}$ ) (Marchon et al., 2016)) ir jos neturi ilgų šoninių grandinių. 
SP veikimo principas - užkirsti kelią smulkių cemento dalelių aglomeravimuisi, t. y. flokuliacijai. Cemento malimas suteikia dalelėms paviršiaus krūvius. Šie krūviai lokalizuojami skirtinguose taškuose, todèl dalelè kartu gali turèti teigiamuosius ir neigiamuosius krūvius. Skirtingose dalelèse esantys priešingi ženklų krūviai sukelia dalelių agregaciją (dèl didelių Van der Waalso traukos jègu), atstumas tarp dalelių siekia 5-7 nm, (Cheung et al., 2011) ir sudaro flokuliato masę. SP, tokie kaip PMS ir PNS, susideda iš ilgų grandinių organinių molekulių, turinčių keletą anijoninių polinių grupių [sulfoninès $\left(-\mathrm{SO}_{3} \mathrm{H}\right)$ ir hidroksilo $(-\mathrm{OH})]$ angliavandenilių grandinèje. Kai jie pridedami prie cemento-vandens sistemos, poliarinè grandinè adsorbuojama cemento dalelių paviršiuje, sukuriant neigiamajji krūvị, kuris lemia elektrostatinị atstūmimą tarp dalelių ir stabilizuoja jų dispersiją. Be to, neigiamasis krūvis sudaro orientuotų vandens molekulių apvalkalą aplink kiekvieną dalelę. Taip atskiriant daleles, išlaisvinamas vanduo, dèl to mažèja klampa ir dideja dalelių judrumas.

PCE ir PCE-PA pagrindu sukurtos plastifikuojančios betono įmaišos naudojamos dẻl polimerų adsorbcijos ant cemento dalelès paviršiaus. PCE ir PCE-PA dèl elektrostatinio krūvio bei erdvinès (sterinès) stūmos jègos disperguoja krūvị turinčias cemento daleles ir sudaro kliūtis dalelèms sąveikauti (Burgos-Montes et al., 2012; Huynh et al., 2006; Ouattara et al., 2017). Daugumos tyrëjų nuomone (Kim et al., 2018; Wang et al., 2018a; Winnefeld et al., 2007), sterinès (erdvinès) stūmos jègos atlieka pagrindinị vaidmenị disperguojant cemento daleles ir išlaisvinant sulaikytą aglomeratuose vandenị.

SP poveikis šių cementinių medžiagų reologinėms savybèms yra susijęs su polimero kiekiu, adsorbuotu ant cemento dalelių paviršiaus (Wang et al., 2018a). Kai PCE įmaišomi ị cemento tešlą, šarminèje terpèje vyksta vandenilio atskèlimas nuo karboksilo grupių, dèl to šoninès PCE molekulių grandys virsta neigiamai ikrautos ir šios karboksilo grupès adsorbuojamos cemento dalelių paviršiuje. Šoninès grandinès neleidžia dalelèms priartèti viena prie kitos, neigiamai įkrautos cemento dalelès atstumia viena kitą. Skirtingų tipų šoninių grandinių schemos pateiktos 1.3 paveiksle (Wang et al., 2018b). Šoninių grandinių ilgis, tankis ir išsidèstymas ant kamieno gali skirtis. Dispersinis efektas priklauso nuo karboksilo (karboksirūgšties grupès) grupių skaičiaus; didesnis karboksilo grupių skaičius pagrindinejje grandinejje palengvina greitą adsorbciją (Aiad et al., 2018; Chen, 2013). PCE sintezès metu šoninèms grandinèms paprastai naudojamas PEG arba PEO (polietileno oksidas), kurio molinè mase gali kisti nuo 750 iki $5000 \mathrm{~g} / \mathrm{mol}$. Skirtingos molinès masès ir ilgio šoninès PEG grandys gali būti ịterpiamos ị tą pati polimerą sintezès metu, taip reguliuojant ir balansuojant krūvio tankị. PEG šoninès grandinès suteikia PCE aukštą hidrofiliškumą. Sintezuotų PCE hidrofilinị pobūdi galima sumažinti naudojant vietoj PEG polipropileno oksido (PPO) šonines grandines, kurias polimerizuojant sukuriamos mišrios šoninès grandinès, jų tirpumas vandenyje skirtingas. PCE struktūroje PPO šoninès grandinès sumažina 
itraukto oro kiekị. Praktiškai tai reiškia, kad, esant labai mažam V/C santykiui, PCE polimerai su ilgomis šoninėmis grandinėmis ir dideliu karboksilinių grupių / esterio $(\mathrm{C} / \mathrm{E})$ santykiu gali efektyviau neutralizuoti traukos jègas tarp dalelių nei polimerai, kurių C/E santykis yra mažas ir polimero struktūroje vyrauja trumpos šoninès grandinès (Björnström \& Chandra, 2003; Wang et al., 2018a). Taip pat nustatyta, kad PCE krūvio charakteristikos daugiausia lemia jų adsorbcijos elgseną ir lètinantị poveikị cemento tešlos rišimuisi tokia tvarka: $-\mathrm{COO}^{-}>-\mathrm{SO}^{-3}$ $>\equiv \mathrm{N}^{+}$. Taigi kuo trumpesnè pagrindinè grandinè ir kuo ilgesnès ir gausesnès šoninès grandinès, tuo didesnis ir ilgalaikiškesnis yra tešlos tinkamumo laikas.

Dispersinis poveikis priklauso nuo karboksilo grupių skaičiaus; aukštesnès karboksilo grupès pagrindinèje jungčiu grandinejje palengvina greitą adsorbciją (Mangane et al., 2018b).

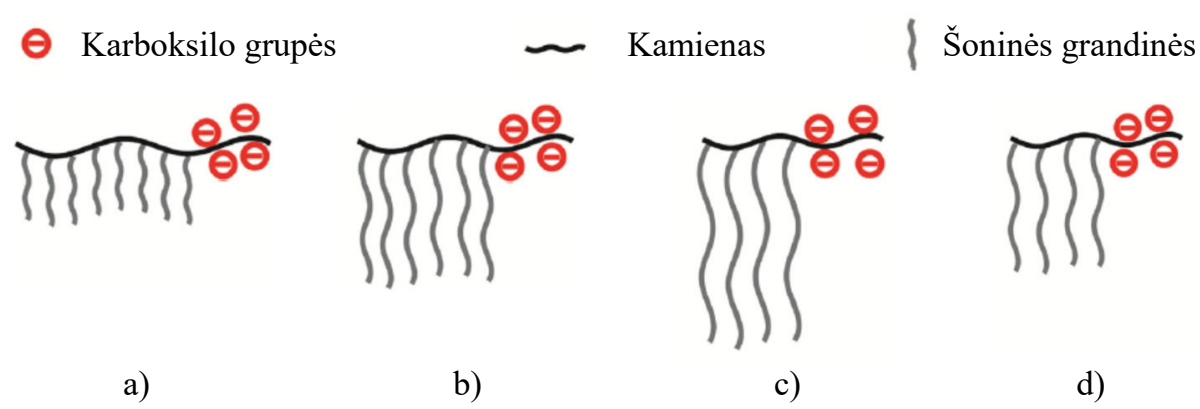

1.3 pav. Plastifikuojančių betono įmaišų skirtingų tipų šoninių grandinių schemos: a) didelio tankio trumpos grandinès; b) didelio tankio vidutinio ilgio grandinès; c) mažo tankio ilgos grandinès; d) mažo tankio vidutinio ilgio grandinès (Wang et al., 2018b) Fig. 1.3. Schematic drawing of plasticizers different side chains: a) high density short chains; b) high density medium-length chains; c) low density long chains; d) low density medium-length chains (Wang et al., 2018b)

Modifikuojant PCE ir keičiant didelị kiekị karboksilo grupių kitomis (pvz., PEG arba PPO) galima pasiekti dar mažesnę cemento tešlos klampą, nes polimeras geriau adsorbuojasi cemento dalelių paviršiuje, kartu minimaliai pailgindamas rišimosi trukmę (Hamada et al., 2009). Apibendrinant daroma išvada, kad kuo trumpesnis pagrindinès grandinès funkcinių grupių ilgis, tuo geresnis poveikis cemento tešlos sklidumui. Betono, pagaminto naudojant tokị modifikuotą PCE, pradinis mechaninis stipris dideja labai lètai. To priežastis yra gausus cemento paviršiuje adsorbuotų PCE molekulių skaičius, lètinantis cemento hidrataciją. Tačiau po keliu parų mechaninis stipris pasiekia ịprastinę tokiam betonui vertę.

Daugelis faktorių (cemento tipas, smulkumas, priemaišų kiekis) gali paveikti SP absorbciją cemento dalelių paviršiuje. PCE yra jautrūs ir mažai efektyvūs sudètyse su molio mineralais. Jeigu betono sudètyje yra molio mineralų, PCE su 
ilgomis šoninėmis grandimis absorbuojasi ant molio mineralų paviršiaus, todèl labai išauga PC dozavimas betono sudètyje, o rišimasis vyksta lěčiau $(\mathrm{Ng} \&$ Justnes, 2015). LS ir kiti tradiciniai SP nèra jautrūs molio mineralams. Pavyzdžiui, tyrime (Burgos-Montes et al., 2012) tradiciniai SP buvo palyginti su PCE plastifikuojančiomis betono įmaišomis ir nustatyta, kad LS, PNS ir PMS adsorbcija CEM I tipo cemento dalelių paviršiuje buvo didesnè nei PCE. Adsorbcija buvo susijusi su krūvio tankiu ir adsorbuotų molekulių konfigūracija. Tradicinès SP, tokios kaip LS, PNS ir PMS, turèjo 16-20 kartų didesnes adsorbcijos vertes nei PCE plastifikuojanti betono įmaiša CEM I tipo cementams. Intensyviausiai ant cemento paviršiaus adsorbavosi LS, pasižymintis didžiausiu $\mathrm{R}-\mathrm{SO}^{-3}$ grupių skaičiumi, kurios paprastai yra LS sudètyje. Palyginti greitas cemento tešlos tinkamumo praradimas, esant LS, gali būti susijęs su jonų kiekio padidejimu (joninio stiprio padidèjimu) vandens terpèje, dèl kurio didèja adsorbuotų polioelektrolitų sluoksnių suspaudimas ir silpnèja elektrostatinès stūmos jẻgos. Dèl šios priežasties Van der Waalso traukos jègos vèl sukelia cemento dalelių flokuliaciją (Robert et al., 2018). Be to (Mangane et al., 2018b), SP pridejjimas uždelsia cemento hidrataciją priklausomai nuo jų tipo. Labiausiai tai pasireiškia LS ir PNS atveju, PMS ir PCE atveju šis uždelsimas buvo mažiau išreikštas.

Akrilo pagrindo (PCE-PA) kopolimeruose kamieno monomeru vienetas yra akrilo rūgštis, o jungtis tarp šių vienetų ir šoninių grandinių yra esterinė arba amidinè (Chen, 2015; Marchon et al., 2016). Poliakrilatu veikimo principas - elektrostatinis dispergavimas (stiprus cemento dalelių $\xi$ potencialo perstūmimas ị neigiamą sriti). PCE-PA molekulès absorbuojasi aplink cemento daleles metaakrilato molekulès susiformuoja linijinèse molekulèse $(\sim 8-9 \mathrm{~nm})$, todèl tarp cemento dalelių išnyksta flokuliacijos efektas. Teigiama, kad PCE-PA pasižymi didesniu krūvio tankiu ir geresne geba adsorbuotis ant cemento dalelių paviršiaus nei PCE. Jeigu PCE-PA šoninès grandinèlès yra labai ilgos, krūvio tankis mažèja. Jiao et al. (2017) nustatè, kad PCE-PA efektyviausiai gerina cemento tešlos reologines savybes, lyginant su LS, PMS ir modifikuotais PNS.

\subsubsection{Plastifikuojančių betono ịmaišų poveikis cemento hidratacijai}

Skirtingi SP pasižymi skirtingais adsorbcijos ir lètinimo efektais, o tai glaudžiai koreliuoja su jų specifine molekuline struktūra (Bishop \& Barron, 2006; Feng et al., 2018; Kong et al., 2016; Li et al., 2017; Meier et al., 2017; Plank \& Hirsch, 2007; Ridi et al., 2012; Zhang et al., 2015).

Visi SP pailgina cemento hidratacijos indukcini periodą ir slopina hidratacijos reakciją. Tai susiję su didesniais polimeru adsorbcijos greičiais aliuminato fazèje nei alito fazèje (Liu et al., 2013; Zingg et al., 2008, 2009). Tradicinès SP cemento tešloje gali uždelsti ir modifikuoti hidratų, ypač portlandito užuomazgų 
atsiradimą ir augimą, adsorbuojantis ant hidratų paviršiaus. Todèl ịprastinès kristalų augimo kryptys gali būti blokuojamos (Bishop \& Barron, 2006). Jei slopinamas portlandito susidarymas, $\mathrm{C}_{3} \mathrm{~S}$ toliau nebetirpsta, nes tirpalo prisotinimo laipsnis nesikeičia, o tai neleidžia toliau susidaryti CSH, dèl ko indukcijos laikotarpis pailgeja (Marchon et al., 2016).

Visų SP poveikis pagrịstas jų adsorbcija ant teigiamai ịkrautų cemento dalelių, daugiausia ant etringito (AFt fazè ) ir monosulfato per SP jonines grupes (pvz., sulfonatą arba karboksilatą) (Ferrari et al., 2012; Ng \& Plank, 2012; Plank et al., 2009, 2010). Kaip žinoma, sulfato jonai (kaip specifinis cemento priedas) pirmiausia reaguoja su aliuminatine faze ant cemento dalelių paviršiaus. Daugelio SP veikimo efektyvumas cemento tešloje priklauso nuo tirpių cemento sulfatų ir aktyvių aliuminatinių fazių pusiausvyros, nes, susidarant mineralinėms fazėms, organinių junginių adsorbcija riboja vandens patekimą prie cemento dalelių paviršiaus.

Taip pat nustatyta, kad LS arba kitos sulfonintos SP (pvz., PNS, PMS) nuo pat hidratacijos proceso pradžios labiau sąveikauja su aliuminatinemis fazèmis. Be to, labai svarbu pabrèžti, kad LS arba kitos sulfonintos SP nestabdo etringito susidarymo. Pavyzdžiui, tyrime (Burgos-Montes et al., 2012), lyginant tradicinių SP (LS, PMS ir PNS) ir PCE poveiki CEMI tipo cemento hidratacijos produktams, buvo nustatyta, kad etringitas pastebimai daugiau adsorbuoja ant savo paviršiaus LS, PMS ir PNS, nei PCE. Adsorbuotas jų kiekis etringite buvo apytiksliai $20 \%$ didesnis nei PCE. Sulfatų perteklius gali sumažinti PCE veiksmingumą, nes susidaranti AFt fazè adsorbuojasi ant cemento paviršiaus ir trukdo PCE patekti prie cemento dalelès. LS ir kitos SP taip pat yra veikiamos sulfato jonų kiekio, tačiau ši įtaka gerokai mažesnè. Tyrejjai (Bishop \& Barron, 2006) atkreipè dėmesi ị tai, kad cemento tešlos tinkamumo praradimas naudojant LS įvyksta dèl spartejjančio etringito susidarymo. LS pasižymi didžiausiu R-SO-3 grupių kiekiu, tiesiogiai dalyvaujančiu adsorbcijoje. Palyginti greitas cemento tešlos su LS tinkamumo praradimas gali būti susijęs su joninio stiprio padidèjimu. Dèl šio efekto adsorbuoti polielektrolito sluoksniai suspaudžiami, elektrostatinis atstūmimo efektas silpnèja ir vèl vyksta cemento dalelių flokuliacija.

PCE aktyviai dalyvauja hidratacijos procese, yra aktyvūs hidratacijos proceso modifikatoriai, veikiantys ne tik hidratacijos trukmę, bet ir hidratacijos produktų susidarymą, t. y. turintys ịtakos stiprumo savybèms, struktūrai ir ilgaamžiškumui (Bishop \& Barron, 2006; Meier et al., 2017; Plank \& Hirsch, 2007; Ridi et al., 2012; Zhang et al., 2015). Tyrejjai pastebejjo, kad ankstyvosios cemento hidratacijos metu indukcinis laikotarpis bus tuo ilgesnis, kuo mažesnio ilgio šoninès grandinès ir didesnis karboksilato ir PEO grupių santykis yra pagrindineje (kamieninejje) PCE grandinejje (Cheung et al., 2011; Marchon et al., 2018). Galimi tokie hidratacijos mechanizmai: 1) dèl polimerų adsorbcijos cemento paviršiuje sumažeja vandens ir $\mathrm{Ca}^{2+}$ jonų difuzija; 2) darinių susidarymas porų tirpale tarp $\mathrm{Ca}^{2+}$ 
jonų ir PCE; 3) hidratuotų fazių augimo kinetikos ir morfologijos pokyčiai, kuriuos sukelia PCE adsorbcija cemento dalelių paviršiuje.

Irodyta, kad anijoniniai polimerai, tokie kaip PCE, tirpina silikatus, aliuminatus, sudaro kompleksus, jungiasi su cemento hidroksidais ị sluoksniuotus dvigubus hidroksidus, kurie paskui sudaro mineralines fazes (Chen et al., 2019; Ng \& Justnes, 2016; Ng et al., 2013; Plank et al., 2010). Šios mineralinès fazès kiekis yra proporcingas PCE krūvio tankiui ir atvirkščiai proporcingas PCE molekulinei masei.

Buvo nustatyta, kad visų tipų PCE yra labiau adsorbuoti aliuminato fazèje nei alito fazejje. Hidratacijos metu etringitas sugeba adsorbuoti 2-4 kartus daugiau neigiamai ịkrauto PCE nei monosulfatas arba CSH (Meier et al., 2017; Plank \& Hirsch, 2007). Svarbu pažymèti, kad PCE daugiausia sulètina alito tirpimą (Plank et al., 2009).

Polimerai, turintys didesnę molekulinę masę, mažesnį šoninių grandinių tankị ir trumpesnes šonines grandines, ant cemento dalelių adsorbuojasi stipriau nei polimerai su mažesniu krūvio tankiu (Zhang et al., 2015). Šis atradimas koreliuoja su reologiniais parametrais. Tyrëjai įrodè, kad sumažèjęs šoninių grandinių tankis padidina cemento skiedinio tinkamumą (padidèja skiedinio sklidumo skersmuo, sumažèja cemento tešlos klampa, sumažèja ribiniai šlyties ịtempiai) (Guo et al., 2017).

Sanchez, Zhang \& Ince (2009) tyrime elektrinio laidumo matavimais buvo nustatyta, kad PCE stabdo $\mathrm{C}_{3} \mathrm{~S}$ tirpimą cemento tešloje ir elektrinio laidumo didèjimą, bei manoma, kad skatina $\mathrm{CSH}$ ir kitų hidratų susidarymą. Hidratuojant $\mathrm{C}_{3} \mathrm{~S}$ ir susidarant $\mathrm{CSH}$ užuomazgoms, tarp $\mathrm{Ca}^{2+}$ jonų ir didelio krūvio tankio karboksilato polimerų susidaro kompleksai (Ridi et al., 2012). İvairūs tyrimai rodo, kad PCE gerina $\mathrm{C}_{3} \mathrm{~A}$ tirpimą, todèl greičiau susinaudoja sulfatai ir susidaro etringitas (Bishop \& Barron, 2006; Meier et al., 2017; Plank \& Hirsch, 2007; Ridi et al., 2012). Tačiau yra ir priešinga nuomonè, kad SP adsorbuojasi sulfatų paviršiuje ir lètina jų tirpimą, tuomet sulfatai netrukdo $\mathrm{C}_{3} \mathrm{~A}$ tirpimui (Burgos-Montes et al., 2012; Marchon et al., 2016; Meier et al., 2017).

Ibragimov \& Fediuk (2019) darbe buvo palygintas skirtingo tipo SP poveikis cemento hidratacijai. Nustatyta, kad naudojant PNS po 1 paros kietinimo cemento bandiniuose etringito kiekis padidejo $12 \%$, portlandito - $10 \%$, alito sumažèjo $16 \%$, lyginant su kontrolinių bandinių be SP, o naudojant PCE po 1 paros kietinimo etringito kiekis padidèjo $10 \%$, portlandito - $77 \%$, o belito sumažèjo $25 \%$. SP lètinantị efektą ir dispersinị poveikị, kuris keičia augimo kinetiką ir hidratavimosi fazių morfologiją, autoriai aiškina skirtingu adsorbuoto polimero kiekiu ir cementinių dalelių paviršiaus padengimu SP.

Tačiau mokslininkai (Gelardi \& Flatt, 2016; Marchon \& Flatt, 2016; Plank et al., 2008) nustatè, kad PCE- PA pagrindinè (kamieninè) grandis, sudaryta tik iš poliakrilato rūgšties monomerų, nedaro įtakos $\mathrm{C}_{3} \mathrm{~S}$ hidratacijai. Tai bandoma paaiškinti tuo, kad susidaro mažai tirpios poliakrilo rūgšties kalcio druskos, kurios 
netrukdo tolesnei cemento hidratacijai. Pagrindinè šio polimero grandis yra mažiau aktyvi nei jo šoninè grandis (Gelardi \& Flatt, 2016; Plank et al., 2008). Studijuojant akrilato pagrindu ir metakrilato pagrindu sudarytų PCE poveiki portlandcemenčių su skirtingais šarmų ir trikalcio aliuminato kiekiais hidratacijai, buvo nustatyta, kad metakrilato pagrindu pagamintų PCE sukeltas hidratacijos uždelsimas priklauso nuo adsorbuotų polimeru kiekio, o akrilato pagrindu pagamintų PCE sukeltas hidratacijos uždelsimas priklauso nuo polimero, likusio porų tirpale, kiekio. Padaryta išvada, kad metakrilato pagrindu sudaryti PCE skatina pradinį $\mathrm{C}_{3} \mathrm{~S}$ tirpimą, o neadsorbuoti akrilato pagrindu pagaminti PCE daugiausia skatina CSH susidarymą.

Be to, literatūroje dažnai minima, kad cemento ir parinkto SP sudètis (dèl pH ar SP koncentracijos) gali nesiderinti. Tuomet cemento tešla greitai praranda tinkamumą arba sumažèja hidratacijos greitis (Burgos-Montes et al., 2012; Marchon \& Flatt, 2016; Pourchet et al., 2007; Wang et al., 2018a).

\subsubsection{Daugiasienių anglies nano vamzdeliụ dispergavimas}

Norint MWCNTs naudoti cementinèse medžiagose labai svarbu, kad MWCNTs tolygiai pasiskirstytų vandeniniame tirpale. Dažniausiai tai pasiekiama fizikiniais ir cheminiais metodais. Nepoliarinès anglies pagrindu pagamintas nanostruktūras sunku disperguoti labai poliariškose terpèse, tokiose kaip vanduo, todėl ultragarsinis dispergavimo metodas taikomas dažniausiai. Daugiausia bandymų MWCNTs dispergavimo laipsniui nustatyti buvo atlikta tiriant ultragarso energijos ar ultragarso trukmès įtaką (Konsta-Gdoutos et al., 2010b; Li et al., 2020; Yu et al., 2007).

Tyrëjai atskleidè, kad MWCNTs dispergavimo laipsnis pagerejo didinant ultragarso dispergavimo galią (Zou et al., 2015), taip pat ir iki tam tikros ribos ilginant laiką (Li \& Lin, 2019). Tačiau ultragarso efektyvumas sklaidai yra ribotas, per didelè ultragarso galia ir trukmè skatina MWCNTs reaglomeraciją. Todėl tyrejjai ultragarso metodą derino su cheminiu metodu, tokiu būdu optimizuodami MWCNTs dispergavimą. Norint hidrofobinius MWCNTs efektyviau disperguoti vandenyje, naudojamos komerciškai prieinamos PAM, tokios kaip PCE, PA, natrio dodecilbenzeno sulfonatas, „Pluronic F127“, ir „Triton X-100“ (TX10) (Collins et al., 2012; Konsta-Gdoutos et al., 2010b; Parveen et al., 2015; Yu et al., 2007; Zou et al., 2015). „Pluronic F127“ pirmą kartą sékmingai buvo panaudotas MWCNTs dispergavimui 2015 m. (Parveen et al., 2015). „Pluronic F-127“ cheminę struktūrą sudaro hidrofobinès grandinès (PPO) ir polietileno oksido šoninès grandinès (PEO). PEO grandinès veikia panašiai kaip naudojami PCE cementiniuose kompozituose, o PPO grandinès gali būti absorbuojamos MWCNTs paviršiuje, taip užtikrinant „Pluronic F127“ veiksmingumą. Optimalus „Pluronic F127“ 
kiekis, užtikrinantis tirpalo dispersiją be aglomeratų buvo $3 \%$ nuo MWCNTs suspensijos kiekio.

Taip pat buvo tirta galimybe formuoti giminingas jungtis tarp MWCNTs ir PAM (cikloheksanolis, fenolis, naftalenas) (Liew et al., 2016). Nustatyta, kad adsorbcija ir jungčių susidarymas priklauso nuo PAM struktūros.

Dėl Van der Waalso traukos jègų MWCNTs adsorbuoja PAM hidrofobinę dalị ant sienelių šonų arba vamzdelių galuose, kai tirpumą vandenyje ir elektrostatinị atstūmimą užtikrina hidrofilinè PAM dalis (Collins et al., 2012; Szleifer \& Yerushalmi-Rozen, 2005). Dèl to padidèjo MWCNTs hidrofiliškumas ir pagerèjo MWCNTs dispergavimo efektyvumas. Elektrostatinio atstūmimo diapazoną ir stiprumą lemia MWCNTs paviršiuje adsorbuotų polimerų tankumas ir polimerų grandinių ilgis (Szleifer \& Yerushalmi-Rozen, 2005). Schemiškai PAM veikimo mechanizmas ant MWCNTs paviršiaus pavaizduotas 1.4 ir 1.5 paveiksluose (Liew et al., 2016).

Siūlomi trys galimi PAM sąveikos su MWCNTs paviršiumi variantai: PAM inkapsuliavimas cilindrinejje micelèje (Matarredona et al., 2003; O'Connell et al., 2001), hemi-micelinè adsorbcija (Richard et al., 2003) ir atsitiktiné adsorbcija (Yurekli et al., 2004). Tačiau kartais cheminès jungtys tarp MWCNTs ir PCE tipo PAM gali būti suformuotos per cheminę ịterpimo reakciją po ilgo ultragarsinio dispergavimo (Cui et al., 2017). Taigi PCE tipo PAM, absorbuotos MWCNTs, išlaiko laisvas polines grupes ir teoriškai gali reaguoti su teigiamai įkrautomis cemento dalelèmis. Tačiau Makar \& Chan (2009) tyrime konstatuota, kad PCE yra neveiksmingas disperguojant ultragarsu MWCNTs ir neužkerta kelio MWCNTs pakartotiniai aglomeracijai pasibaigus dispergavimui. Tačiau Yu et al. (2007) tyrimas parode, kad kai MWCNTs koncentracija vandenyje viršija 1,5 \%, naudojant ultragarsą ir natrio dodecilbenzeno sulfonatą (SDBS) disperguoti MWCNTs netgi nepavyksta. Bet kiti tyrimai tam prieštarauja.

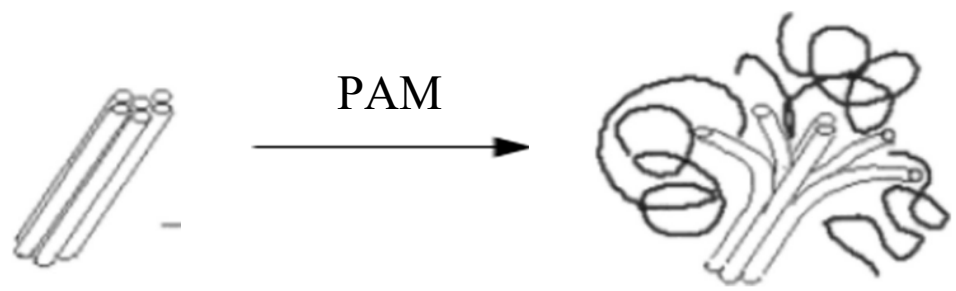

1.4 pav. Anglies nanovamzdelių pasiskirstymas veikiant paviršiaus aktyvių medžiagu PAM (Liew et al., 2016)

Fig. 1.4. Carbon nanotube bundles distribution after PAM impact (Liew et al., 2016) 
a)
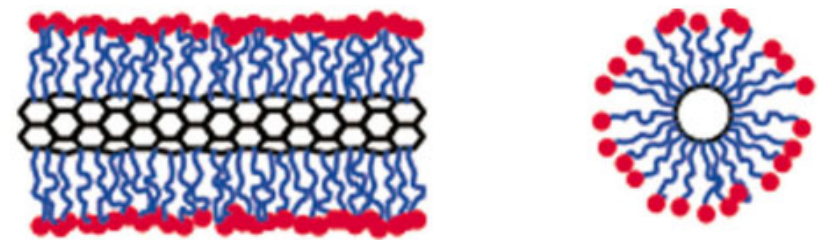

b)

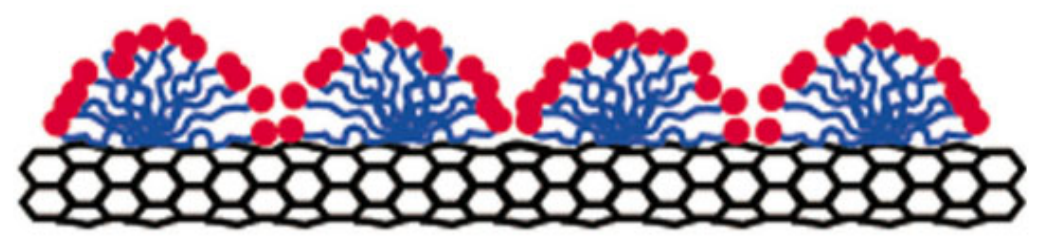

c)

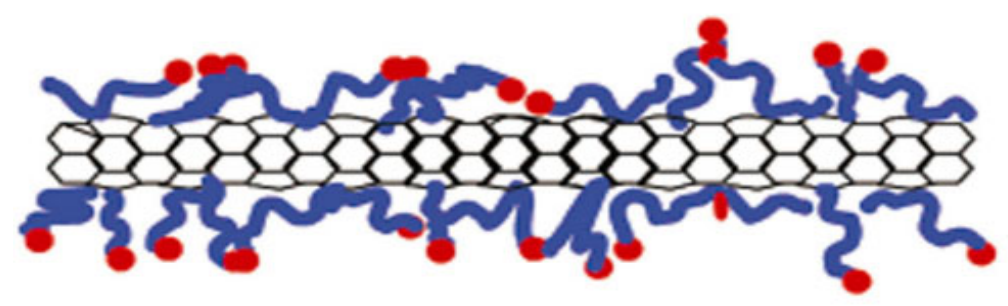

1.5 pav. Schema mechanizmų, kuriais paviršiaus aktyvios medžiagos padeda disperguoti daugiasienius anglies nano vamzdelius, vaizdas:

a) daugiasienis anglies nano vamzdelis inkapsuliuotas paviršiaus aktyvios medžiagos micelèje; b) hemi-micelinè adsorbcija; c) atsitiktinė adsorbcija (Liew et al., 2016)

Fig. 1.5. Representations of the mechanisms by which surfactants help to disperse multi- walled carbon nanotubes: a) encapsulated in a cylindrical PAM micelle;

b) hemimicellar adsorption; c) random adsorption (Liew et al., 2016)

Skirtingų tipų SP (LS, PNS ir PCE) poveikį MWCNTs dispergavimui tyrę mokslininkai (Kim et al., 2018) nustate, kad labiausiai vandens tirpale MWCNTs dispergavo PCE. PCE dozavimo poveikis cemento tešlos sklidumui (matuotas pasklidimo skersmuo) parodè, kad optimalus PCE/MWCNTs masės santykis yra 8 (Zou et al., 2015). Tačiau ši nuomonè gali būti nepagrịsta atsižvelgiant ị tai, kad pagal kitus tyrimus (Konsta-Gdoutos et al., 2010b) MWCNTs gerokai padidina cemento tešlos klampą.

Cheminis MWCNTs apdorojimas modifikuojant MWCNTs paviršių hidrofilinėmis funkcinèmis grupèmis gali pagerinti MWCNTs dispersijos laipsnį vandeniniame tirpale (Eitan et al., 2003; Li \& Lin, 2019). Apdorojant stipria rūgštimi vyksta cheminè reakcija ir MWCNTs paviršiuje prijungiamos karboksilato ir hidroksilo grupès. Kaip rodo tyrimas (Mendoza et al., 2013), MWCNTs paviršių modifikacija koncentruotu sieros ir azoto rūgšties mišiniu, kurių masès santykis buvo 
3:1, paskatino karboksilato grupių prijungimą ir, lyginant su neapdorotais MWCNTs, labai pagerino MWCNTs dispergavimo efektyvumą (Mendoza et al., 2013).

Apibendrinant galima teigti, kad ịvairios PAM skiriasi savo savybèmis, todèl optimalus PAM/MWCNTs santykis kiekvienu atskiru atveju turi būti nustatytas tyrimais. Turint omenyje, kad PAM (išskyrus SP) yra nenaudingos cemento hidratacijos procese ir nèra rekomenduojamos, jų vaidmenị gali atlikti ịvairios kitos SP, tokios kaip PCE ir PCE-PA, kurių taikymas turi būti kruopščiai ištirtas.

\subsubsection{Daugiasienių anglies nano vamzdeliụ sąveika su plastifikuojančiomis betono įmaišomis cemento tešlose}

Paskutiniais metais PCE pradèti naudoti cementinèse medžiagose su MWCNTs (Collins et al., 2012). Cemento tešloje pagrindinè PCE molekulès grandis orientuota ị vandens molekulę, o šoninè grandis yra orientuota link MWCNTs suspensijos aglomeratų. Tokiu būdu MWCNTs aglomeratai yra tarsi sugauti micelès viduje, o nuolatinis tešlos maišymas lemia papildomą MWCNTs dispergavimą (Liebscher, Lange et al., 2017). Esmini vaidmenị čia atlieka PCE molekulès architektūra, taip pat aplinkos parametrai, tokie kaip pH ir temperatūra (Liebscher, Fuge, et al., 2017). Buvo nustatyta, kad PCE su ilgesnèmis pagrindinemis grandimis disperguoja MWCNTs efektyviau nei PCE su trumpesnèmis pagrindinèmis grandimis. Taip pat nurodoma, kad dispergavimui palankesnè yra šarminè aplinka (Liebscher, Fuge, et al., 2017; Liebscher, Lange, et al., 2017).

MWCNTs dispergavimas su skirtingais SP (LS, PNS ir PCE) (Kim et al., 2018) parodè, kad ant cemento paviršiaus PNS ir LS adsorbuoto sluoksnio storis yra mažesnis kaip $50 \AA$, tuomet PCE adsorbuoto sluoksnio storis yra maždaug $100 \AA ̊$, todèl traukos jëgos tarp MWCNTs silpnejja. Beje, Van der Waalso jègos tarp MWCNTs labai sumažèja, kai atstumas tarp MWCNTs dalelių yra maždaug 2,0-12,0 $\AA$ (Arash et al., 2015). Kitame tyrime (Cwirzen \& Habermehl-Cwirzen, 2013) PCE-PA buvo panaudotas MWCNTs dispergavimui cemento tešloje. PCE-PA kiekis sudare $2,1 \%$ masès nuo vandens, reikalingo skirtingiems MWCNTs kiekiams $(0,023-0,14 \%)$ disperguoti. Didžiausias cementinių bandinių mechaninių savybių patobulinimas gautas tuomet, kai PCE-PA ir MWCNTs masès santykis neviršija 15.

Liebscher et al. (2020) tyrime buvo ištirtas dviejų skirtingų PCE (šukų tipo kopolimerų, kurie skiriasi savo pagrindinès (kamieninès) grandies ilgiu) poveikis MWCNTs dispergavimui. PCE, pasižymintis ilgesne pagrindine grandine, buvo 3,5 kartus ilgesnis nei PCE su trumpa pagrindine grandine. Buvo nustatyta, kad PCE su ilgesne pagrindine grandine kur kas geriau disperguoja MWCNTs nei PCE su trumpesne pagrindine grandine. Tačiau didžiausias ankstyvasis gniuž- 
dymo ir lenkimo stipris buvo nustatytas cementinès matricos bandiniuose, pagamintuose su PCE, kuris prasčiau dispergavo MWCNTs. PCE su trumpesne pagrindine grandine labiau sutankino cementinę matricą, o bandiniai su PCE, pasižyminčia ilgesne pagrindine grandine, turèjo porètą mikrostruktūrą, rodančią cemento hidratacijos lètinimą.

Kaip nurodo daugelis tyrèjų, MWCNTs priedas mažina cemento mišinių sklidumą ir tinkamumą (Alatawna et al., 2020; Kostrzanowska-Siedlarz, 2020; Wang et al., 2017). Atlikti tyrimai (Collins et al., 2012; Konsta-Gdoutos, Batis et al., 2017; Konsta-Gdoutos, Danoglidis et al., 2017) rodo, kad cemento tešlų sklidumas priklauso nuo MWCNTs kiekio ir V/C santykio. Didinant MWCNTs kieki cemento tešloje nuo 0,5 iki $2,0 \%$ (nuo cemento kiekio) ir palaikant cemento teš$\operatorname{los} \mathrm{V} / \mathrm{C} 0,4,0,5$ ir 0,6, sklidumo rezultatai buvo tokie: didinant V/C sklidumas didèjo, tačiau didinant MWCNTs kiekị cemento tešloje sklidumas smarkiai mažèjo. Esant V/C 0,4, sklidumas mažèjo nuo 60 iki $40 \mathrm{~mm}$, esant V/C 0,5, sklidumas mažèjo nuo 80 iki $40 \mathrm{~mm}$, esant V/C 0,6, sklidumas mažèjo nuo 100 iki $60 \mathrm{~mm}$.

Paskutiniu metu cementinių kompozitu su MWCNTs klampai mažinti pradèti naudoti ịvairūs PCE tipo SP (Jalal et al., 2019; Nadiv et al., 2016). Cementinių skiedinių su skirtingais $\mathrm{V} / \mathrm{C}$ santykiais $(0,4-0,5)$, MWCNTs kiekiais $(0-0,16 \%$ nuo cemento kiekio) ir PCE (nuo 0,55 iki 1,1\% nuo cemento kiekio) reologiniai tyrimai (Kostrzanowska-Siedlarz, 2020) parodè, kad didžiausią ịtaką skiedinio klampai ir paviršiaus įtempiui pirmiausia daro V/C santykis, paskui PCE kiekis, po to $\mathrm{V} / \mathrm{C}$ ir PCE santykis, o mažiausia ịtaką daro MWCNTs kiekis. Didžiausią itaką plastinei klampai turi $\mathrm{V} / \mathrm{C}$ santykis.

Cementinių kompozitų su MWCNTs suspensija, PCE ir oro ịtraukimą mažinančia įmaiša konsistencijos tyrimai (Parveen et al., 2015) parodè, kad abu priedai smarkiai sumažino MWCNTs neigiamą poveikị cemento tešlos sklidumui.

Skirtingo MWCNTs kiekio ( $0,1 \mathrm{iki} 0,5 \%$ nuo cemento masès) ir PCE poveikis cemento tešlos sklidumui ir sukietejusių bandinių savybèms buvo ištirtas Vesmawala et al. (2020) darbe. Buvo nustatyta, kad bandinių su PCE priedu sklidumas buvo didesnis nei analogiškų bandinių be PCE priedo. Didèjant MWCNTs kiekiui sudètyje, gniuždymo stipris taip pat didejo - po 7 parų stipris augo nuo 36 iki $38 \mathrm{MPa}$, o po 28 parų kietejjimo - nuo 49,2 iki 62,6 MPa. Bandinių su PCE gniuždymo stipris taip pat didejjo, didèjant MWCNTs kiekiui, po 7 parų kietejjimo stiprio vertès buvo $17 \%$ didesnès (nuo 43,8 iki 45,7 MPa), o po 28 parų kietèjimo - $23 \%$ didesnès (nuo 67,8 iki 80,6 MPa) nei bandinių be PCE. Tyrëjai mano, kad tinkamiausias MWCNTs kiekis sudettyje yra $0,1 \%$ nuo cemento masès. 


\subsubsection{Daugiasieniu anglies nano vamzdeliụ poveikis cemento tešlos hidratacijai}

MWCNTs priedas veikia cemento tešlos hidrataciją. MWCNTs kiekio (nuo 0,1 iki $0,5 \%$ nuo cemento masès) poveikio cemento hidratacijai 24 valandų laikotarpiu (Li et al., 2020), tyrimas atskleidè, kad MWCNTs kiekiai $(0,2-0,5 \%$ ) skatina cemento hidrataciją ir greitina šilumos išsiskyrimą. Tačiau $0,1 \%$ MWCNTs akivaizdžiai sumažino bendrą cementinių kompozitų hidratacijos šilumą. Autoriai mano, kad MWCNTs, turintys didelę paviršiaus energiją, gali padidinti CSH polimerizaciją. Remiantis XRD tyrimais, MWCNTs nedaro poveikio cemento hidratacijos produktų mineralinei suděčiai, tačiau gali sumažinti kalcio hidroksido kristalų orientacijos indeksą. Mikrostruktūros stebejimai parodè, kad MWCNTs taip pat gali pakeisti hidratacijos produktų morfologiją ir modifikuoti cementinių kompozitu mikrostruktūrą.

Makar and Chan (2009) tyrime nustatyta, kad MWCNTs cemento tešloje gali pa-greitinti $\mathrm{C}_{3} \mathrm{~S}$ hidratacijos reakciją. Kiti autoriai (Amin et al., 2015; Tafesse \& Kim, 2019; Torabian Isfahani et al., 2016) teigia, kad MWCNTs gali pailginti cemento tešlos rišimosi pradžios ir pabaigos laiką, tačiau didesnis $(1 \%)$ MWCNTs kiekis neturèjo ịtakos rišimosi trukmei (Alatawna et al., 2020; Cui et al., 2017; Guan et al., 2020; Li \& Lin, 2019; Nadiv et al., 2016). Pirmiau minèti duomenys patvirtina, kad mažesni MWCNTs kiekiai (iki 0,2 \%) neabejotinai pagerina cementinių medžiagų hidrataciją ir fizikines savybes, tačiau didesnis MWCNTs kiekio poveikis nepakankamai išaiškintas.

Kai kurie tyrejai mano, kad MWCNTs skatina cemento hidrataciją ir veikia kaip kristalų užuomazgos (Laukaitis et al., 2012), kiti tyrejjai (Amin et al., 2015) mano, kad MWCNTs neturi didelio poveikio hidratacijos procesui. $1 \%$ (nuo cemento masès) MWCNTs poveikio cemento hidratacijai tyrimai (Cui et al., 2015) parodè, kad per pirmąsias 3 valandas MWCNTs akivaizdžiai nekeičia cemento tešlos hidratacijos proceso eigos. Praejus trims valandoms prasideda pirmasis pastebimas šilumos išsiskyrimas, siejamas su $\mathrm{C}_{3} \mathrm{~S}$ hidratacija ir $\mathrm{CSH}$ bei etringito susidarymu. Sukietejjusio cemento akmens mikrostruktūros tyrimai parodè, kad cemento hidratacijos produktai tvirtai prisitvirtina prie MWCNTs paviršiaus, todèl manoma, kad MWCNTs yra tarsi užuomazgos taškai cemento hidratacijos produktams susidaryti. Kitas tyrimas (Xu et al., 2015) taip pat patvirtino, kad MWCNTs kiekio didinimas skatina cemento hidratacijos procesą, CSH susidarymą ir mažina $\mathrm{CH}$ kristališkumą. Atlikti tyrimai (Makar \& Chan, 2009) parodė, kad MWCNTs gali skatinti $\mathrm{C}_{3} \mathrm{~S}$ hidratacijos procesą ir veikia kaip užuomazgos jo hidratacijos produktų kristalizacijai. MWCNTs paviršius greitai pasidengia plonu CSH sluoksniu ir taip suformuoja tvirtas sąsajas struktūroje. Taip pat pastebèta, kad MWCNTs turi poveiki $\mathrm{C}_{3} \mathrm{~A}$ ir $\mathrm{C}_{3} \mathrm{~S}$ hidratacijos produktų morfologijai. Huang et al. (2018), Yang et al. (2019) tyrimuose buvo nustatyta, kad MWCNTs pavir- 
šius adsorbuoja papildomus $\mathrm{Ca}^{2+}$ jonus, todèl sparteja $\mathrm{CSH}$ gelio ir $\mathrm{CH}$ susidarymas. Tyrimais (Cwirzen et al. 2009; Cwirzen \& Habermehl-Cwirzen 2013) buvo nustatyta, kad ị ruošiamą cemento tešlą pridejus 0,045-0,15 \% MWCNTs (pagal cemento masę), cemento akmens bandinių gniuždymo stipris padidejo apie $50 \%$.

\subsubsection{Daugiasienių anglies nano vamzdeliụ sąveika su orą itraukiančiomis įmaišomis cemento tešlose}

Putbetonis pastaraisiais metais labai dažnai naudojamas visame pasaulyje. Putbetonis yra akytujų betonų rūšis, sudarytas iš cemento, priedų ir OIP. OIP paskirtis porizuoti cementinę matricą ir užtikrinti smulkių porų susidarymą joje (Chen \& Liu, 2010; Nambiar \& Ramamurthy, 2006; Nowak-Michta, 2019; Zhang \& Liu, 2019). OIP kilmè (pvz., proteinu arba sintetiniu pagrindu) dèl savo itakos putų stabilumui gali smarkiai paveikti bandinių gniuždymo stiprio rezultatus (Chandni \& Anand, 2018; Falliano et al., 2018; Gökçe et al., 2019). Oro burbuliukai cemento tešloje iš prigimties yra nepatvarūs. Priklausomai nuo maišymo intensyvumo bei trukmès ir naudojamos ịmaišos rūšies, galima sukurti putbetonị su skirtingais poretumo parametrais. Putbetonio oro tarpu struktūra yra esminè charakteristika, lemianti jo savybes, tokias kaip stipris ir ilgalaikiškumas (Hilal, Thom \& Dawson, 2015; Yu et al., 2010).

Statybose naudojamas ypač lengvas (tankis $100-300 \mathrm{~kg} / \mathrm{m}^{3}$ ) putbetonis. Pagrindinis jo trūkumas - labai mažas gniuždymo stipris, dèl kurio jis naudojamas neplačiai, todèl būtina pagerinti tokio lengvo putbetonio gniuždymo stiprị (Zhang \& Liu, 2019). Tačiau tai nėra paprastas uždavinys, nes vidutiniškai gniuždymo stiprio kritimas yra 5,5\%, kai mišinyje yra įtraukiama $1 \%$ oro (Nowak-Michta, 2019). Siekiant pagerinti tokio betono gniuždymo stiprį, naudojami ịvairūs pluoštai (polipropileno pluoštas, stiklo pluoštai, keramikos pluoštai, MWCNTs) (Chen \& Liu, 2010; Nambiar \& Ramamurthy, 2006). Tačiau polipropileno ir stiklo pluoštu poveikis putbetoniui yra nedidelis. Autorių (Zhang \& Liu, 2019) tyrimai rodo, kad naudojant MWCNTs putbetonyje galima padidinti betono gniuždymo stipri, nes putbetonio tešloje aktyviau vyksta $\mathrm{C}_{3} \mathrm{~S}$ hidratacija, o MWCNTs labai glaudžiai sukimba su CSH ir užtikrina jų augimą. Tinkamas MWCNTs dispergavimas užtikrina geresnę oro tuštumų struktūrą putbetonyje. Pavyzdžiui, Zhang and Liu (2019) darbe, kuriant didesnio stiprumo, ypač lengvą putbetonį, buvo naudojamos labai trumpos MWCNTs (skersmuo - 10-30 nm, ilgis - 5-15 $\mu \mathrm{m}$ ), kurių kiekis svyravo nuo $(0,05$ iki $0,35 \%$ nuo cemento masès), o dispergavimui buvo parinktas $\mathrm{Ce}\left(\mathrm{SO}_{4}\right)_{2}$. Šių autorių atlikti tyrimai parodè, kad MWCNTs labai prisideda prie putbetonio ankstyvojo gniuždymo stiprio augimo. Didejant putbetonio (be MWCNTs priedo) tankiui nuo $200 \mathrm{iki} 250 \mathrm{~kg} / \mathrm{m}^{3}$, po 7 parų kietejjimo bandinių gniuždymo stipris didejo nuo 0,24 iki $0,4 \mathrm{MPa}$, o pridejus ị analogiškos sudèties MWCNTs priedą ( 0,05 iki $0,2 \%$ nuo cemento masès), gniuždymo stipris didejjo 
nuo 0,32 iki 0,6 MPa. Po 28 paru kietejjimo betono, kurio sudètyje nebuvo MWCNTs priedo, gniuždymo stipris augo nuo 0,3 iki $0,48 \mathrm{MPa}$, o betono su MWCNTs priedu - nuo 0,4 iki 0,75 MPa. Didesnis nei 0,2\% MWCNTs kiekis bandiniu gniuždymo stiprio nedidina, o dar didesni MWCNTs kiekiai $(0,3$ ir $0,35 \%$ nuo cemento masès) bandinių gniuždymo stiprị smarkiai sumažina. Tačiau MWCNTs yra linkusios ị aglomeraciją, todèl būtina parinkti tinkamas chemines betono įmaišas. I cementini putbetoni pridèjus $0,05 \%$ MWCNTs (pagal cemento masę) bandinių gniuždymo stipris padidejo apie $70 \%$ (nuo 1,8 iki 3,06 MPa) (Metaxa et al., 2012).

Be to, buvo nustatyta, kad MWCNTs gali smarkiai pagerinti putbetonio porų ir oro tuštumų sienelių kokybę ir jų stiprị, sumažinti mikroporų ir oro tuštumų skaičių, jų dydị (skersmenį) ir užtikrinti tolygų tuštumų pasiskirstymą. Nustatyta (Zhang \& Liu, 2019), kad bandinių gniuždymo stipris tiesiogiai priklauso nuo oro tuštumų kiekio, tačiau oro tuštumų dydžio įtaka gniuždymo stipriui yra daug mažesnè nei bandinio poringumui. MWCNTs priedas labai nežymiai mažina bandinių poringumą.

Kiti autoriai ištyrè putbetonio su MWCNTs mechanines savybes. Buvo tirtas MWCNTs priedo poveikis autoklaviniam betonui (Keriene et al., 2013; Laukaitis et al., 2012). Nustatyta, kad MWCNTs efektyviai pagerina bandinių lenkimo ir gniuždymo stiprị, nes veikia kaip kristalizacijos užuomazgos ir skatina kristalų augimą, kartu stebimas džiūstamojo traukumo sumažèjimas. Be to, bandiniuose su MWCNTs pastebètas porų vidutinio skersmens sumažèjimas.

Baloch et al. (2018) darbe išanalizuotas MWCNTs poveikis putbetonio atsparumui ugniai. Nustatyta, kad MWCNTs pagerina atsparumą ugniai ir bandinių tamprumo moduli.

Yakovlev et al. (2006) darbe buvo nustatyta, kad MWCNTs gali padidinti putbetonio mechanines savybes ir sumažinti šilumos laidumą dẻl modifikuotos porų sienelių struktūros ir tolygesnio porų dydžio pasiskirstymo. Be to, MWCNTs gali veikti kaip tilteliai tarp nanodydžio ịtrūkių ar tuštumų, kad būtų sumažintas ịtrūkių skaičius ir padidintas lenkimo stipris (Petrunin et al., 2015; Shi et al., 2019b).

Wang et al. (2020a) darbe buvo tirti lengvieji putbetoniai, be ir su MWCNTs priedu, kurių tankis buvo $1500 \mathrm{~kg} / \mathrm{m}^{3}$. Buvo konstatuota, kad MWCNTs padidina gniuždymo stiprị po 1,7 ir 28 parų atitinkamai $18,5 \%, 16,5 \%$ ir 12,7\%, lyginant su putbetoniu be MWCNTs priedo, o lenkimo stipris padidèjo 37,1 \%. Remiantis autorių tyrimais matyti, kad MWCNTs pasižymi užpildo funkcija, tankinant porų sienelių struktūrą ir tuo pat metu sumažinant kapiliarinių porų ir mikrotuštumų dydị bei tūrį. Toks reiškinys labiausiai pasireiškia fazių sąlyčio zonoje, nes MWCNTs gali veikti kaip kristalų užuomazgų susidarymo vietos dėl MWCNTs didelès paviršiaus energijos, o hidratacijos produktai aktyviau nusèda ant jų paviršiaus, todèl fazių sąlyčio zonoje ankstyvajame hidratacijos etape galètų būti 
pagamintas didesnis (CSH) kiekis. MWCNTs jungiamają gebą gali padidinti funkcionalizuotas MWCNTs paviršius, kuris dẻl kovalentinių ryšių tarp funkcinių grupių ir hidratacijos produktų gali sukurti tvirtus sąsajų ryšius su cementine matrica. Pridejus MWCNTs, putbetonio tamprumo modulis padidejo nuo 12,6 GPa iki 14,5 GPa, t. y. 15,1\%. Sukietejusio cemento akmens elastinis modulis priklauso (didèjimo tvarka) nuo porètos fazès, mažo standumo CSH, didelio standumo $\mathrm{CSH}$, kalcio hidroksido ir nehidratuotos fazès. Bet, naudojant nanoindentifikavimo technologiją, buvo pastebèta, kad MWCNTs įdejjimas gali padidinti didelio standumo CSH kiekị.

Nustatyta (Blandine et al., 2016; Hogancamp \& Grasley, 2017), kad MWCNTs gali efektyviai sumažinti chemini ir džiūstamaji susitraukimą vienu metu. Smulkesnès kapiliarų poros (ypač 10-50 nm dydžio), kurios vyrauja susitraukiant betonui, užpildomos MWCNTs, kurių skersmuo yra panašus. Dèl to ir kapiliarinis poringumas sumažeja. Palyginus su putbetoniu be MWCNTs priedo, bendras cheminis ir džiūstamasis traukumas bandiniuose su MWCNTs priedu yra tris kartus mažesnis. Be to, MWCNTs geba užpildyti smulkiausias poras, labai sumažina vandens prasiskverbimo ir pralaidumo lygius atitinkamai 45,8 \% ir 70,6 \%. Šis atradimas rodo, kad MWCNTs tankina matricą, mažina kapiliarų poras, kuriose yra nesurištojo vandens, sudarančio šiose porose MWCNTs ir nanodydžio kristalitų jungtis. Kita vertus, putbetonio be MWCNTs priedo mikrostruktūra sudaryta iš stambesnių porų, kuriose kristalizuojasi didesni kalcio hidroksido plokštelių kristalai.

\subsection{Daugiasienių anglies nano vamzdelių poveikis cementinių medžiagų savybėms}

Nanotechnologijų naudojimas cementinių sistemų savybėms pagerinti yra sparčiai besivystanti sritis. Iki šiol buvo siūlyta ịvairių būdų, kaip sutvirtinti cementines medžiagas skirtingos rūšies pluoštais, tokiais kaip polipropilenas ir nailonas, natūrali celiuliozė (pvz., kietmedžio ir spygliuočių medienos plaušas), ir neorganiniais pluoštais, tokiais kaip plienas, stiklas ar anglis (Musso et al., 2009). Tačiau mokslininkai pripažįsta, kad už tradicines armavimo medžiagas, tokias kaip anglies pluoštas ir stiklo pluoštas, MWCNTs yra veiksmingesnès (Liew et al., 2016). Yra žinoma, kad MWCNTs yra labai efektyvi medžiaga, kurią galima naudoti kaip priedą ịtrūkiu plitimams betone mažinti (Li et al., 2005). MWCNTs armavimo mechanizmas cementinèse medžiagose gali būti paaiškintas keliais veiksniais (Shi et al., 2019a): 
1. Užpildymo efektas. Paprastai cementinès medžiagos yra porètos, o MWCNTs, būdamos labai mažo dydžio, atlieka užpildo vaidmenį sukietejusiame cemento akmenyje. Poringumo tyrimai rodo, kad MWCNTs sumažina poringumą, poros pasiskirsto tolygiau, taigi padidejja tankis ir pagerëja cemento akmens mechaninès savybès.

2. Jungiamasis efektas. MWCNTs cementinèje medžiagoje atlieka tam tikrą jungiamajị efektą, sudarydamos tiltelius tarp mikroịtrūkių. Tokie tilteliai gali apriboti vidinių mikroịtrūkių vystymąsi cementinèje medžiagoje, taip prisidedami prie mechaninių savybių pagerinimo.

3. Kristalų užuomazgų efektas. Cemento hidratacijos metu MWCNTs gali suteikti tam tikrą hidratacijos centrų - kristalų užuomazgų efektą. Tokios užuomazgos veikia hidratacijos procesą, padidina CSH gelio kiekị sukietejusiame cemento akmenyje (Konsta-Gdoutos et al., 2010b), keičia hidratacijos produktų mikrostruktūrą, didina hidratacijos produktų kristališkumą ir galiausiai pagerina cemento akmens mechanines savybes (Cui et al., 2015).

Pastaraisiais metais daugybė eksperimentų ir tyrimų parodè, kad labai mažas MWCNTs kiekis gali smarkiai pagerinti cemento pagrindu pagamintų kompozitų mechanines savybes (Li et al., 2005; Manzur et al., 2014; Wang et al., 2013). Hidratacijos proceso ir mikrostruktūros tyrimai padeda paaiškinti MWCNTs poveiki cemento akmens savybèms.

\subsubsection{Daugiasienių anglies nano vamzdelių poveikis cemento akmens stiprumo savybèms}

Wang et al. (2013) darbe nustatyta, kad kompozito sudetyje panaudojus MWCNTs $(0,2 \%$ cemento masès $)$ ịprastinio portlandcemenčio akmens lenkimo stipris padidèjo $\sim 58 \%$, o poringumas sumažèjo $\sim 21 \%$. Panašius rezultatus, panaudojus MWCNTs, aprašė ir kiti autoriai (Siddique \& Mehta 2014; Li et al., 2005; Parveen et al., 2015; Sobolkina et al., 2012; Wang et al., 2013; Xu et al., 2015). Šiuose darbuose nustatyta, kad pridëjus $0,08-0,1 \%$ MWCNTs (nuo cemento kiekio) gniuždymo stipris dideja nuo 10 iki $40 \%$, lenkimo stipris - nuo 9,3 iki $43 \%$. Kai MWCNTs kiekis siekia 0,5\% (nuo cemento kiekio), gniuždymo stipris dideja nuo 10 iki $19 \%$, lenkimo stipris - nuo 7 iki $25 \%$.

Maži MWCNTs kiekiai (pvz., 0,048-0,30 \% cemento masės) ne tik padidina cementinių medžiagų gniuždymo ir lenkimo stiprius, bet ir tankị bei kietumą ( $\mathrm{Abu}$ Al-Rub et al., 2012; Manzur et al., 2014; Nasibulina et al., 2012; Parveen et al., 2015; Peyvandi et al., 2013; Tyson et al., 2011; Yazdanbakhsh et al., 2012). Didesni MWCNTs kiekiai (0,5\% cemento masès ar daugiau) mechanines savybes 
pagerina tik šiek tiek arba net jas ir pablogina (Musso et al., 2009; Sanchez et al., 2009).

Konsta-Gdoutos, Batis et al. (2017) turime buvo tirtas MWCNTs priedo, kurio kiekis sudetyje kito nuo 0,05 iki $0,8 \%$, poveikis cementinių skiedinių lenkimo ir gniuždymo stipriui po 3 ir 28 parų kietejjimo. Labiausiai bandinių lenkimo ir gniuždymo stipris po 3 ir 28 parų kietėjimo didèjo sudètyse, kuriose MWCNTs sudare $0,05-0,1 \%$ nuo visos skiedinio masès. Kai MWCNTs kiekis buvo didinamas iki 0,8\%, skirtumas tarp 3 ir 28 paras kietintų bandinių lenkimo ir gniuždymo stiprių buvo nedidelis. Tačiau autoriai daro išvadą, kad, didejjant MWCNTs kiekiui, gniuždymo ir lenkimo stiprio padidejjimas tapo stabilesnis.

Atlikti cementinių kompozitų su MWCNTs gniuždymo stiprio bei ilgaamžiškumo tyrimai rodo (Galao et al., 2012), kad, didejjant MWCNTs kiekiui nuo 0 iki $2 \%$, gniuždymo stipris palaipsniui didèja. Bandinių gniuždymo stipris po 7 parų kietejimo padidèja apytiksliai $9 \%$, po 28 parų - apie $7 \%$, po 120 parų - apie $14 \%$. Autorių nuomone, MWCNTs padidinimas cemento skiedinyje $1 \%$ atitinka $5,3 \%$ skiedinio gniuždymo stiprio padidejjimą.

Daugelis tyrējų pabrèžia, kad i cementinių kompozitų sudètị ịdèjus MWCNTs arba anglies nanopluošto, sukurtų medžiagų tamprumo modulis gali būti gerokai padidintas (Konsta-Gdoutos, Batis et al., 2017; Shi et al., 2019a). Tyrimai rodo, kad cemento skiedinio sudetyje naudojant $0,1 \%$ MWCNTs ir $0,1 \%$ anglies nano-pluošto, bandinių tamprumo moduliai yra atitinkamai 2 ir 2,1 karto didesni nei kontrolinio bandinio be priedų.

Trumpų MWCNTs ir ilgo anglies nanopluošto kiekio poveikio cementinio kompozito savybių įvertinimui tyrèjai (Konsta-Gdoutos et al., 2010b) atliko seriją eksperimentu. Cemento kompozite naudojant 0,048, 0,08 ir 0,10\% (nuo cemento masès) MWCNTs ir 0,048, 0,08 ir 0,10\% anglies nanopluoštą, buvo nustatyta, kad maksimalias gniuždymo stiprio vertes po 28 parų kietejjimo pasiekẻ kompozitai su 0,08 \% MWCNTs. Padaryta išvada, kad kompozitai, kurių sudètyje buvo panaudoti ilgi anglies nanopluoštai, pasižymi žemesnèmis gniuždymo stiprio vertėmis nei kompozitas su trumpais (iki $15 \mu \mathrm{m}$ ) MWCNTs. Kitas panašus tyrimas (Wang et al. 2013) buvo atliktas su MWCNTs, disperguotais anijonitineje dervoje. MWCNTs kiekis cementiniame kompozite buvo $0,05,0,08,0,10,0,12$ ir $0,15 \%$ (nuo cemento masès). Nustatyta kad po 28 parų kietejjimo gniuždymo stipris proporcingai didejo, didejjant MWCNTs kiekiui nuo 0 iki $0,10 \%$, o tolesnis MWCNTs didinimas iki $0,15 \%$ veikia priešingai ir bandinių gniuždymo stipris mažèjo. Šie rezultatai rodo, kad per didelis MWCNTs kiekis gali mažinti gniuždymo stiprị, todèl, norint užtikrinti geriausią jo poveikị cemento pagrindu pagamintoms medžiagoms, naudojamas MWCNTs kiekis turètų būti parenkamas labai kruopščiai. 


\subsubsection{Daugiasienių anglies nano vamzdeliụ poveikis cemento akmens mikrostruktūrai}

Daugybė atliktų mikrostruktūros tyrimų parodè (Konsta-Gdoutos et al., 2010a; Liu et al., 2014; Nochaiya \& Chaipanich, 2011), kad cemento akmens porose ir tuštumose MWCNTs sudaro tiltelių tinklo struktūras (1.6 pav.). Šios struktūros užpildo įtrūkius ir poras (1.7 pav.), taip sumažindamos cemento akmens poringumą ir didindamos tankį. Be to, MWCNTs kaip užuomazgų centrai gali inicijuoti daugybės hidratacijos produktų susidarymą ant jų paviršiaus (1.8 pav.), taip sutvirtindami MWCNTs ir cemento akmens ryšius bei sulètindami plyšių susidarymą ir vystymąsi.

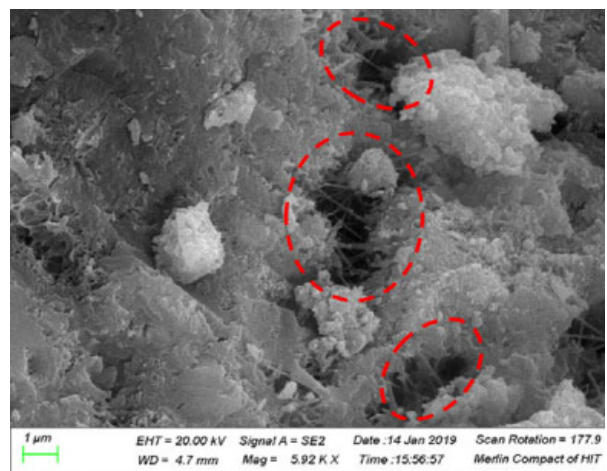

1.6 pav. Daugiasienių anglies nano vamzdelių tinklelio struktūros susidarymas 35 paras kietejusiame cemento akmenyje (didinimas $-\times 5900$ ) (Guan et al., 2020)

Fig. 1.6. Cementitious stone with multi-walled carbon nano tubes bridges, after 35 days of curing (magnification $-\times 5900$ ) (Guan et al., 2020)

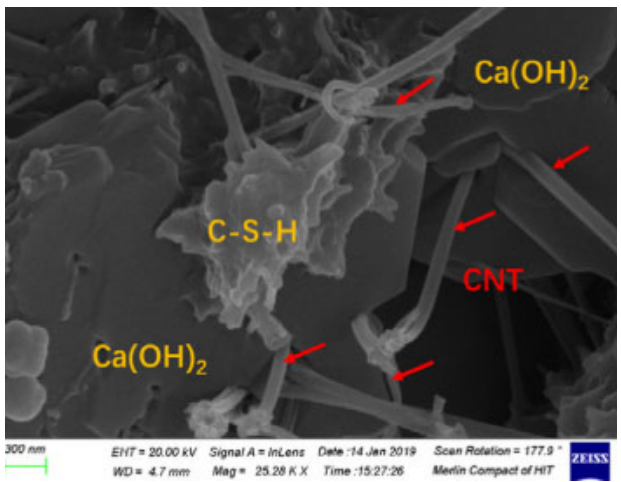

1.7 pav. Hidratacijos produktai 35 paras kietejjusiame cemento akmenyje su daugiasieniais anglies nano vamzdeliais (didinimas $-\times 25000)$ (Guan et al., 2020)

Fig. 1.7. Hydration products in cementitious stone with multi-walled carbon nano tubes MWCNTs, after 35 days of curing (magnification $-\times 25000$ ) (Guan et al., 2020) 


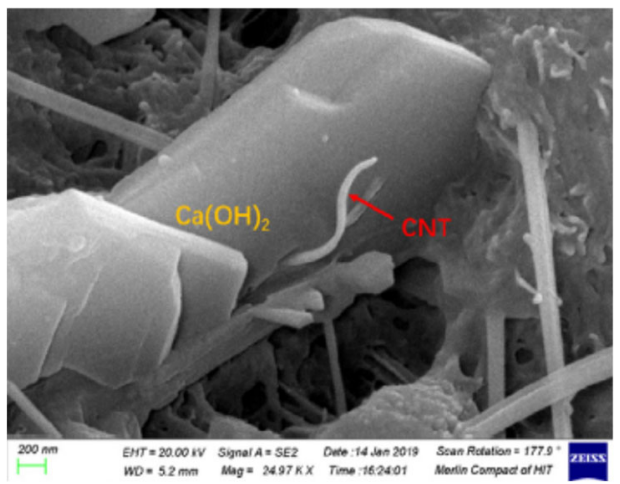

1.8 pav. Daugiasienių anglies nano vamzdelių sąveika su $\mathrm{CH}$ kristalais cemento akmenyje didinimas (didinimas $-\times 25000) 25000$ (Guan et al., 2020)

Fig. 1.8 Multi-walled carbon nano tubes penetrating $\mathrm{CH}$ crystals (magnification $-\times 25000)$ (Guan et al., 2020)

Per didelis MWCNTs kiekis cemento akmenyje gali susilpninti armavimo poveikį, nes MWCNTs aglomeracija sukelia didelių ertmių atsiradimą cemento akmenyje (Liu et al., 2014). Kaip nurodo tyrejai (Li et al., 2015) cementinio kompozito su $0,5 \%$ MWCNTs poringumas yra $64 \%$ mažesnis nei kompozito be MWCNTs priedo ir siekia 10,8\%. Tyrinejant cemento ir lakiųu pelenų kompozito su 0,5 ir $1 \%$ MWCNTs mikrostruktūrą, buvo konstatuota (Chaipanich et al., 2010; Wang et al., 2014), kad MWCNTs tilteliai užpilde poras tarp CSH ir etringito, taip padidindami kompozito tankị.

\subsubsection{Daugiasienių anglies nano vamzdelių poveikis cemento akmens džiūstamajam traukumui, ilgaamžiškumui ir šilumos laidumui}

Ankstyvajame cemento kietejjimo periode dèl drègmès išsikyrimo bandiniai susitraukia ir susitraukimo įtempiai veikia susidariusių cemento hidratacijos produktų tūrị. Šis tūrio pokytis yra tiesiogiai proporcingas mikroporų skaičiui cemento akmenyje ankstyvuoju kietejimo periodu (Radlinska et al., 2008). MWCNTs dèl savo tiltelių sudarymo ir mikroporų užpildymo mažina džiūstamajji traukumą. Panaudojus cemento tešlos sudètyje 0,025 ir $0,048 \%$ (nuo cemento masès) MWCNTs, bandinių susitraukimas sumažèjo 19 ir $30 \%$. Kadangi MWCNTs užpildo įtrūkius ir poras, silpnèja kapiliariniai ir susitraukimo įtempiai, taip neleisdami cemento akmeniui daugiau susitraukti (Konsta-Gdoutos et al., 2010b). Tyrejjai (Blandine et al., 2016) taip pat padare išvadą, kad MWCNTs gali apriboti 
cemento akmens džiūstamajị traukumą. Tačiau didesnis nei 0,5 \% MWCNTs kiekis turejo mažesni poveikị džiūstamajam traukumui dèl padidejjusio cemento akmens poringumo.

Hogancamp and Grasley (2017) tyrimais ịvertinta galimybè naudoti didesnius (iki $3 \%$ nuo cemento masès) anglies nanopluošto kiekius cemento skiedinyje su mikroužpildu ir I/II tipo portlandcemenčiu. Džiūstamojo traukumo tyrimai parodè, kad didesnis - $3 \%$ - anglies nanopluošto kiekis didina bandinių, pagamintų su I/II tipo portlandcemenčiu, džiūstamajị traukumą ir skatina greitesnị ịtrūkių atsiradimą. Bandiniuose su mikroužpildu cemento akmenyje įtrūkių atsiradimo laikas pailgèja 4 kartus.

Cemento pagrindu pagamintų medžiagų ilgaamžiškumas, daugiausia apimantis atsparumą temperatūrų svyravimams (cikliškam užšaldymui-atšildymui) ir atsparumą ịvairių rūšių korozijai, yra labai aktualus, turint omenyje, kad šios medžiagos plačiai naudojamos ịvairiuose pastatuose bei konstrukcijose. Cemento pagrindu pagamintų medžiagų patvarumui įtakos turi ịvairūs veiksniai, tarp kurių svarbiausi yra cementinès matricos poringumas ir porų savybès. Kadangi MWCNTs turi cemento akmens mikroporų užpildymo poveiki ir gerina porų struktūrą (Li et al., 2015), tokių medžiagų ilgaamžiškumas pagerèja. Tyrimas buvo atliktas su cementiniais kompozitais, kurių sudètyje buvo MWCNTs (nuo 0,10 iki $1,0 \%$ nuo cemento masès). Dalis bandiniu buvo laikoma sausomis sąlygomis, o kita dalis buvo testuojami cikliškai užšaldant ir atšildant. Nustatyta, kad MWCNTs pagerina bandinių mechanines savybes tiek laikant sausai, tiek ir po užšaldymo-atšildymo. Sausomis sąlygoms laikytų bandinių cementinio kompozito džiūstamasis traukumas sumažèjo $31,9 \%$, o mechaninès savybės padidèjo iki $30 \%$. Palyginus su kontroliniais bandiniais be MWCNTs po užšaldymo-atšildymo ciklų, cementiniai kompozitai parodè nedidelį mechaninių savybių suprastèjimą.

Cwirzen and Habermehl-Cwirzen (2013) darbe buvo tiriamas 0-2,9\% MWCNTs kiekio poveikis cemento akmens mechaninėms savybėms po užšaldymo-atšildymo ciklų. MWCNTs kartu su SP buvo disperguotas ultragarsiniu dispergatoriumi. Tyrejjai nustatè, kad po užšaldymo-atšildymo ciklų struktūros pažeidimai bandiniuose su MWCNTs buvo nedideli, tačiau, didejjant MWCNTs ir vandens kiekiui skiediniuose, tiltelių efektas silpnejja, o pažeidimai didèja. Be to, tyrime (Guan et al., 2020; Han et al., 2013; Konsta-Gdoutos, Batis et al., 2017) buvo išsiaiškinta, kad MWCNTs cemento akmenyje gali sumažinti vandens absorbciją, vandens ir oro pralaidumą, mažinti koroziją, sukeltą chloridų jonų. Tačiau kiti tyrëjai pateikè skirtingas išvadas (Camacho et al., 2014) ir pabrèžè, kad didesni MWCNTs kiekiai didina cemento akmens poringumą, o tai paskatina chlorido jonų ịsiskverbimą. Galima pabrèžti, kad kompozitų su MWCNTs ilgalaikiškumo tyrimų atlikta nedaug, o tyrimų rezultatai nèra nuoseklūs. 
Kadangi darbo tikslas - sukurti lengvaji kompozitą, MWCNTs poveikis šilumos laidumo koeficientui yra labai svarbus. MWCNTs struktūra leidžia pagerinti kompozitų šilumos laidumo savybes. Mokslininkai (Han et al., 2013; Li et al., 2013) nustatè, kad cementiniai kompozitai su MWCNTs priedu (3\% nuo cemento masès) gali pasiekti $2,83 \mathrm{~W} /(\mathrm{m} \cdot \mathrm{K})$ šilumos laidumo koeficientą, ir tai yra $15-$ 20 \% mažiau nei kompozituose be MWCNTs. Kitas tyrimas (Han et al., 2013; Xu $\&$ Li, 2014) atskleide, kad MWCNTs priedas cementiniame kompozite su fazių kaitos medžiagomis, apsaugotomis specialiose kapsulèse, taip pat mažina šilumos laidumą ir suteikia geresnes šilumos izoliacijos savybes.

\subsection{Lengvieji cementiniai kompozitai su polistireninio putplasčio atliekomis}

Polistireninio putplasčio (PP) atliekos pagal statistikos klasifikatorių priskiriamos plastikų atliekų kategorijai. Lietuvos statistikos departamento duomenimis, 2019 m. Lietuvoje iš viso susidare 103000 t šių atliekų, kurios buvo išvežtos, sudegintos, apdorotos, pašalintos sąvartyne ir tik 0,245 t panaudota (estatistika, 2019).

Yra siūloma ịvairių būdų, kaip galima panaudoti PP atliekas, tačiau kai kurie iš jų yra labai imlūs energinèms sąnaudoms, o kitais būdais gauti produktai vis tiek patenka ị sąvartynus. Todèl galimybė utilizuoti gamyboje susikaupusias technologines atliekas arba panaudotas medžiagas, pritaikant jas naujiems, efektyviems, energiją taupantiems statybiniams kompozitams kurti, skirtiems pastatu atitvarų konstrukcijoms, yra nuolat tyrèjų dėmesio centre. Lengvasvorès atliekos ir kiti šalutiniai produktai, tinkamai apdoroti, gali būti veiksmingai panaudoti kaip statybinès žaliavos (Merino et al., 2019; Gregorova et al., 2017). Mažo tankio cemento kompozitai gaminami naudojant lengvus poringuosius užpildus ir/arba porodarius, kurie užtikrina porų susidarymą cementineje matricoje. Šie priedai gali būti naudojami kartu. Wang et al. (2020b) išskiria tris lengvujų betonų tipus: lengvujų užpildų betonas (didžiausia dalis oro tuštumų yra užpilduose), akytasis betonas ir putbetonis (oro tuštumos yra cementinèje matricoje), betonas be smulkių dalelių (smèlis nèra naudojamas, todèl oro tuštumos susidaro tarp stambaus užpildo dalelių).

PP atliekos gali būti tradicinių lengvųų užpildų pakaitalais ir naudojamos kaip antrinės, kompozitui suteikiančios geresnių savybių bei aplinkai nekenksmingos žaliavos. Tačiau PP kompozito kūrimas susijęs su dviem pagrindinemis problemomis: 1) dèl mažo stiprumo kompozitas su PP yra netinkamas laikančiosioms konstrukcijoms; 2) maišant kompozito tešlą dèl PP lengvumo (PP yra maždaug 100 kartų lengvesnis už betoną) susiduriama su kompozito tešlos segregacija. Nors PP turi gerų izoliacinių savybių (šilumos laidumo koeficientas 
$\approx 0,04 \mathrm{~W} / \mathrm{m} \cdot \mathrm{K}$ ), šios dvi minètos problemos riboja jo naudojimą kompozituose (Dixit et al., 2019). Problemai spręsti buvo atlikti tyrimai, kuriuose mokslininkai (Dixit et al., 2019) panaudojo 3-5 mm skersmens PP granules, jas įmaišydami penkiomis smèlio tūrio dalimis $(0,16,25,36,45 \%)$ ir formuodami 1463$2301 \mathrm{~kg} / \mathrm{m}^{3}$ tankio kompozitus. Sukurtu kompozitu gniuždymo stipris kito nuo 27,2 iki $149 \mathrm{MPa}$, šilumos laidumo koeficientas - nuo 0,49 iki 2,14 W/m·K. Autorių nuomone, smulkūs kompozito mišinio komponentai atlieka gyvybiškai svarbų vaidmenį tolygiai pasiskirstant PP granulèms. Kai mišinio smulkiagrūdžiai komponentai yra smulkesni nei $1 \mathrm{~mm}$, o $60 \%$ jų yra smulkesni nei $100 \mu \mathrm{m}$, švieŽio mišinio konsistencija panaši ị tirštą tešlą, gana klampią, kad būtų galima išvengti PP segregacijos. Tai aiškinama tuo, kad PP sukuria ypatingą oro tuštumų struktūrą - kuo daugiau sudetyje PP, tuo daugiau kompozite susidaro smulkesnių nei $10^{-4}-10^{-6} \mu \mathrm{m}^{3}$ tūrio oro tuštumų ir porų. Taip pat teigiama, kad tokia struktūra prisideda prie kompozitų ilgalaikiškumo bei šaldymo ir atšildymo ciklų skaičiaus padidinimo (Ferrándiz-Mas \& García-Alcocel, 2013). Kitame tyrime (Cadere et al., 2018) buvo tirtas betonas su lakiaisiais pelenais, dalị užpildo pagal tūrị, iki $20 \%$, pakeičiant PP atliekomis. Betono tankis sumažèjo nuo $2131 \mathrm{~kg} / \mathrm{m}^{3}$ iki $1880 \mathrm{~kg} / \mathrm{m}^{3}$, o gniuždymo stipris - nuo $33 \mathrm{MPa}$ iki $8 \mathrm{MPa}$. Koksal et al. (2020) nustatè, kad keičiant vermikulito + PP / cemento tūrio santyki nuo 3 iki 7, skiedinio tankis dèl didelio poringumo sumažèjo nuo $946 \mathrm{~kg} / \mathrm{m}^{3}$ iki $393 \mathrm{~kg} / \mathrm{m}^{3}$, gniuždymo stipris - nuo 5,89 MPa iki 0,57 MPa, šilumos laidumo koeficientas - nuo $0,445 \mathrm{iki} 0,09 \mathrm{~W} / \mathrm{m} \cdot \mathrm{K}$. Norint sukurti ypač lengvus termoizoliacinius kompozitus, didinama PP dalis kompozito sudètyje (Kligys, 2009). Tokių kompozitų tankis $150-170 \mathrm{~kg} / \mathrm{m}^{3}$, šilumos laidumo koeficientas $-0,06-0,064 \mathrm{~W} /(\mathrm{m} \cdot \mathrm{K})$, gniuždymo stipris - 0,25-0,28 MPa. Panašių kompozitų, naudojant PP granules, šilumos laidumą tyré Sinica (2001). Kai kompozito tankis kito nuo $150 \mathrm{iki} 350 \mathrm{~kg} / \mathrm{m}^{3}$, gniuždymo stipris kito 0,09-0,42 MPa, lenkimo stipris - 0,09-0,39 MPa, šilumos laidumo koeficientas proporcingai PP kiekiui kito nuo 0,048 iki $0,095 \mathrm{~W} /(\mathrm{m} \cdot \mathrm{K})$. Naudojant putstiklio granules kartu su PP atlieka (Šeputytè-Jucikè, 2016), buvo sukurtas termoizoliacinis kompozitas iš modifikuotos cementinès matricos, kurio tankis kito nuo 227 iki $309 \mathrm{~kg} / \mathrm{m}^{3}$, gniuždymo stipris - nuo 0,35 iki $0,73 \mathrm{MPa}$, šilumos laidumo koeficientas - nuo 0,0721 iki $0,0865 \mathrm{~W} /(\mathrm{m} \cdot \mathrm{K})$, vandens garų varžos faktorius $\mu$ - nuo 8 iki 12 ir kurio degumo klasė A2-s1, d0. Mažo tankio kompozitai taip pat buvo sukurti vienodomis dalimis naudojant PP atliekas kartu su polietileno atliekomis (Gregorova et al., 2017). Gautų kompozitų tankis svyravo nuo $250 \mathrm{iki} 375 \mathrm{~kg} / \mathrm{m}^{3}$, gniuždymo stipris - nuo 0,1 iki $0,15 \mathrm{MPa}$, o šilumos laidumo koeficientas kito nuo 0,059 iki $0,085 \mathrm{~W} / \mathrm{m} \cdot \mathrm{K}$.

Šiuo metu, norint gauti didesnio stiprio kompozitus su PP atliekomis, cementinei matricai modifikuoti naudojami nanopriedai, tokie kaip nano- $\mathrm{SiO}_{2}$. Darbe (Fathi et al., 2017) buvo ištirtos lengvojo betono (tankis $1565-1780 \mathrm{~kg} / \mathrm{m}^{3}$ ) su PP 
atliekomis, modifikuoto $\mathrm{SiO}_{2}$ mikrodulkèmis ir nano-SiO tūra. Nustatyta, kad gniuždymo stipris padidejo maždaug 15-25\%, vandens absorbcija sumažejo maždaug 15-20\%, kai sudètyje buvo panaudota $10 \% \mathrm{SiO}_{2}$ mikrodulkių ir $2 \%$ nano- $\mathrm{SiO}_{2}$. Mikrostruktūros tyrimai parodé, kad kompozituose be $\mathrm{SiO}_{2}$ mikrodulkių ir nano- $\mathrm{SiO}_{2}$ priedo $\mathrm{PP}$ granulès nèra pakankamai sukibusios su cemento akmeniu. Sąlyčio zonoje matyti daug tuštumų dèl sferinès PP formos ir lygaus hidrofobinio paviršiaus. Kompozito bandiniuose, turinčiuose $10 \% \mathrm{SiO}_{2}$ mikrodulkių ir $2 \%$ nano- $\mathrm{SiO}_{2}$, sąlyčio zonoje tuštumos beveik išnyksta, o sukibimas tarp PP ir cemento tešlos ženkliai geresnis. Spejjama, kad nano-SiO $\mathrm{S}_{2}$ smarkiai sumažina PP paviršiaus hidrofobiškumą. Kiti tyrimai (Madandoust et al., 2011) rodo, kad nano- $\mathrm{SiO}_{2}$ (kiekis $3 \%$ ) ir $\mathrm{SiO}_{2}$ mikrodulkès (11\%) labai pagerina kompozito fizikines savybes, kai PP kompozite didinamas nuo $10 \%$ iki $30 \%$ pagal tūrị. Svarbu pažymèti, kad abu priedai nepablogina tešlu reologinių savybių, o nano- $\mathrm{SiO}_{2}$ mažina mišinio segregaciją. Didinant PP kieki kompozite, tankis kito nuo $2500 \mathrm{~kg} / \mathrm{m}^{3}$ iki $1600 \mathrm{~kg} / \mathrm{m}^{3}$, gniuždymo stipris - nuo $56 \mathrm{MPa}$ iki $20 \mathrm{MPa}$. Tačiau darbų, kuriuose kompozitams su PP atliekomis kurti cementinei matricai modifikuoti būtų naudojamas MWCNTs priedas, deja, rasti nepavyko.

\subsection{Pirmojo skyriaus išvados ir disertacijos uždavinių formulavimas}

1. Atlikus literatūros analizę matyti, kad daugiasienių anglies nano vamzdelių priedas keičia cementinių kompozitų reologines, taip pat ir sukietejusio kompozito savybes.

2. Cheminių betono ịmaišų ir daugiasienių anglies nano vamzdelių sąveika cemento tešloje, nepaisant atliktų pavienių tyrimų, reikalauja papildomų išsamių bandymų ir analizès. Aišku tai, kad cheminès betono įmaišos turi skirtingą molekulinę struktūrą, krūvio tankị, kamienines grandines ir šoninių grandžių ilgius. Jų adsorbcija, ant cemento dalelių paviršiaus daro skirtingą poveikị cemento mineralų hidratacijai ir sukietejusių bandinių savybèms.

3. Literatūros apžvalga rodo, kad optimalus daugiasieniu anglies nano vamzdelių kiekis kompozito sudètyje priklauso nuo daugybès veiksnių (daugiasienių anglies nano vamzdelių dispergavimo intensyvumo ir trukmès, naudojamų cheminių betono ịmaišų, rišamosios medžiagos mineralinès sudėties, smulkumo, užpildų savybių ir t. t.). Todèl kiekvienu atveju nustatyti optimalų daugiasienių anglies nano vamzdelių kiekị yra būtina norint pasiekti užsibrèžtų tikslų. 
4. Literatūroje rašoma, kad lengvojo kompozito cementinès matricos sukibimui su lengvaisiais užpildais ir kartu tankio mažinimui naudojamos orą įtraukiančios įmaišos. Tačiau literatūroje nèra išsamios informacijos apie bendrą daugiasienių anglies nano vamzdelių, cheminių betono įmaišų ir orą ịtraukiančių įmaišų sąveiką cemento tešloje.

5. Atlikus literatūros analizę nustatyta, kad polistireninio putplasčio atlieku pritaikymas bei jų poveikis lengvuju kompozitų (1000$1500 \mathrm{~kg} / \mathrm{m}^{3}$ ) struktūrai ir eksploatacinėms savybėms yra tirtas daugelio autorių. Pateiktos kompozitu gniuždymo stiprio ir šilumos laidumų vertės svyruoja 9-27 MPa ir 0,33-0,5 W/(m·K) ribose.

6. Labai lengvi kompozitai su polistireninio putplasčio atliekomis (300$500 \mathrm{~kg} / \mathrm{m}^{3}$ ) pasižymi mažu gniuždymo stipriu $0,1-0,5 \mathrm{MPa}$. Tyrimų, aprašančių šių kompozitų su didesnėmis stiprio vertėmis kūrimą yra mažai, nors turint omenyje polistireninio putplasčio atliekų vis didèjančius kiekius, naudojimo potencialas yra didžiulis. Kuriant lengvaji kompozitą ir siekiant mažesnio tankio bei šilumos laidumo, kartu neprarandant stiprumo savybių, svarbu mažinti V/C santykị, naudoti nanopriedus ir chemines įmaišas, parinkti stambaus bei smulkaus lengvasvorių užpildụ santykị taip, kad užsipildytų oro tarpai, tuo užtikrinant panašias arba geresnes nei akytojo betono, kompozito eksploatacines savybes.

Šiam tikslui pasiekti, darbe reikia spręsti tokius uždavinius:

1. Nustatyti daugiasienių anglies nano vamzdelių priedo kiekio poveiki cemento akmens struktūrai bei mechaninèms savybèms ir, remiantis gautais rezultatais, parinkti geriausias mechanines savybes ir struktūrą užtikrinantị daugiasienių anglies nano vamzdelių kiekį.

2. Ištirti daugiasienių anglies nano vamzdelių ir skirtingų cheminių betono įmaišų poveikị, cemento tešlų reologinèms savybèms, cemento hidratacijai, sukietejjusio cemento akmens fizikinėms ir mechaninėms savybėms bei struktūrai ir parinkti geriausias mechanines savybes ir struktūrą užtikrinančias chemines betono įmaišas.

3. Ištirti orą įtraukiančios įmaišos ir daugiasienių anglies nano vamzdelių poveiki cemento akmens fizikinėms ir mechaninèms savybėms bei struktūrai. Išsiaiškinti cementinę matricą modifikuojančių priedų veikimo cemento tešloje ypatumus.

4. Sukurti cementinị kompozitą iš modifikuotos daugiasieniais anglies nano vamzdeliais ir cheminèmis betono įmaišomis cementinès matricos su lengvaisiais trupinto ir frezuoto polistireninio putplasčio atliekų užpildais, ir patikrinti sukurto kompozito atitikimą eksploatacinių savybių reikalavimams. 



\section{2}

\section{Kompozitui sukurti naudotos medžiagos ir tyrimo metodai}

Šiame skyriuje aprašomos moksliniame tiriamajame darbe naudotos medžiagos ir jų savybės, tyrimams naudota ịranga, MWCNTs tirpalo savybių tyrimo metodai, cementinès matricos su MWCNTs ir SP įmaišomis reologijos ir hidratacijos proceso tyrimo metodai bei ịranga. Taip pat pateiktos lengvojo kompozito su PP, MWCNTs ir SP ir OIP įmaišomis tankio, makro- ir mikrostruktūros tyrimų, gniuždymo ir lenkimo stiprio, šilumos laidumo, pralaidumo vandens garams, džiūstamojo traukumo ir vandens sugerties nustatymo metodikos.

Skyriaus tematika paskelbti septyni autoriaus straipsniai (Leonavičius et al., 2017, 2018, 2019a, 2019b, 2019c, 2019d 2020).

\subsection{Naudotos medžiagos}

\subsubsection{Portlandcementis}

Darbe buvo naudotas AB „Akmenès cementas“ CEM I 42,5R portlandcementis (PC). Jis atitinka EN 197-1 reikalavimus. Gamintojo deklaruojama cheminè sudètis bei fizikinès ir mechaninès savybès pateikiamos 2.1 ir 2.2 lentelèse. PC mineralinè sudètis \%: $\mathrm{C}_{3} \mathrm{~S}-56,64, \mathrm{C}_{2} \mathrm{~S}-16,72, \mathrm{C}_{3} \mathrm{~A}-8,96$ ir $\mathrm{C}_{4} \mathrm{AF}-10,59$. 
2.1 lentelè. Portlandcemenčio cheminè sudètis, \%

Table 2.1. Chemical composition of Portland cement, \%

\begin{tabular}{|l|l|l|l|l|l|l|l|l|}
\hline $\mathrm{SiO}_{2}$ & $\mathrm{Al}_{2} \mathrm{O}_{3}$ & $\mathrm{Fe}_{2} \mathrm{O}_{3}$ & $\mathrm{CaO}$ & $\mathrm{MgO}$ & $\mathrm{K}_{2} \mathrm{O}$ & $\mathrm{Na}_{2} \mathrm{O}$ & $\mathrm{SO}_{3}$ & Kitos \\
\hline 19,23 & 4,91 & 3,50 & 62,46 & 3,19 & 0,94 & 0,12 & 3,10 & 2,55 \\
\hline
\end{tabular}

2.2 lentelė. Portlandcemenčio fizikinès ir mechaninès savybès

Table 2.2. Physical-mechanical characteristics of Portland cement

\begin{tabular}{|l|c|}
\hline Savybės & Reikšmé \\
\hline Savitasis paviršius, $\mathrm{cm}^{2} / \mathrm{g}$ & 3700 \\
\hline Dalelių tankis, $\mathrm{kg} / \mathrm{m}^{3}$ & 3200 \\
\hline Piltinis tankis, $\mathrm{kg} / \mathrm{m}^{3}$ & 1200 \\
\hline Normalaus tirštumo tešla, \% & 25,4 \\
\hline Rišimosi pradžia, min. & 140 \\
\hline Rišimosi pabaiga, min. & 190 \\
\hline Gniuždymo stipris po 7 parų kietėjimo, $\mathrm{MPa}$ & 28,9 \\
\hline Gniuždymo stipris po 28 parų kietėjimo, $\mathrm{MPa}$ & 54,6 \\
\hline
\end{tabular}

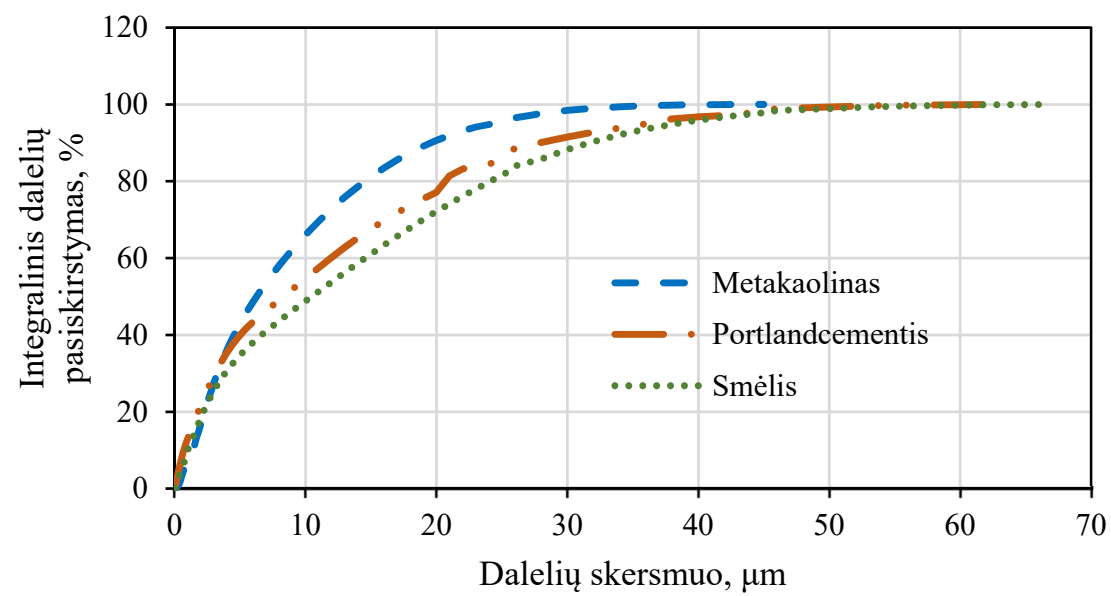

2.1 pav. Portlandcemenčio, smèlio ir metakaolino dalelių pasiskirstymas pagal dydį

Fig. 2.1. The distribution of portland cement, sand and metakaolin particles by size

PC dalelių paskirstymas pagal dydị, kuris pateiktas 2.1 paveiksle, buvo atliktas „CILAS 1090“ prietaisu. Nustatyta, kad mažesnès nei 8,31 $\mu$ m dydžio dalelès sudare $50 \%$ PC. 


\subsubsection{Daugiasieniai anglies nano vamzdeliai}

Darbe naudoti MWCNTs - tai juodos spalvos granulès, kurias sudaro daugiasluoksnių anglies nanovamzdelių ir rišiklio (karboksilmetilceliuliozès) mišinys. Jų vaizdas pateiktas 2.2 paveiksle. Anglies nanovamzdeliai sudaro $45 \%$, o karboksilmetilceliuliozè - $55 \%$ granulių sudèties. Gamintojai nurodo, kad dèl didelès granulëje esančios nanovamzdelių koncentracijos MWCNTs plačiai naudojamos sudètyse su hidrauliniais rišikliais.

Gamintojo deklaruojamas vidutinis MWCNTs dalelių skersmuo yra 10-15 nm, ilgis - 1000-10 $000 \mathrm{~nm}$. MWCNTs vamzdeliai aglomeruoti ị granules, kurių dydis svyruoja 50-900 $\mu \mathrm{m}$, o vidutinis dydis yra apie $400 \mu \mathrm{m}$. (Handling \& Guide, 2012).

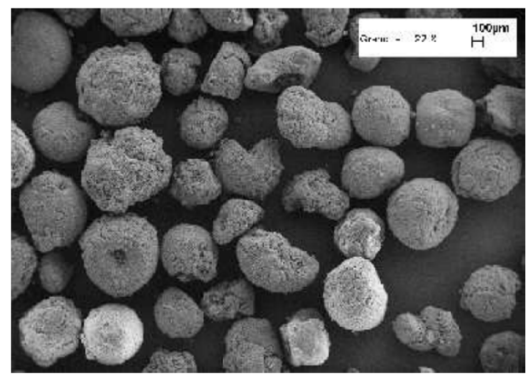

2.2 pav. Padidintas daugiasienių anglies nano vamzdelių granulių vaizdas (magnification $-\times 1000$ ) (Bordere et al., 2011)

Fig. 2.2. Enlarged image of multi-walled carbon nano tubes bundles (magnification $-\times 1000)$ (Bordere et al., 2011)

Darbe buvo naudojamas 0,00005-0,5\% MWCNTs (pagal MWCNTs kiekị granulèje) nuo PC kiekio. Prieš naudojant granulès turi būti paruoštos pagal gamintojo nurodytą metodiką, kuri aprašyta toliau.

\subsubsection{Maltas smèlis}

Kaip smulkusis užpildas buvo naudojamas UAB „Matuizų dujų silikatas“ pramoniniu šlapiuoju būdu, rutuliniame malūne, maltas smèlis (SM). Gautas šlapias smèlio šlamas išdžiovintas laboratorinèje džiovykloje $+(105 \pm 3){ }^{\circ} \mathrm{C}$ temperatūroje. SM piltinis tankis $-1065,4 \mathrm{~kg} / \mathrm{m}^{3}$, savitasis paviršius $-3150 \mathrm{~cm}^{2} / \mathrm{g}$. Gamintojo pateikta smèlio cheminè sudètis pateikta 2.3 lentelèje.

2.3 lentelè. Smèlio cheminè sudètis, \%

Table 2.3. Chemical characteristics of sand, $\%$

\begin{tabular}{|c|c|c|c|}
\hline $\mathrm{SiO}_{2}$ & $\mathrm{Al}_{2} \mathrm{O}_{3}+\mathrm{TiO}_{2}$ & $\mathrm{Fe}_{2} \mathrm{O}_{3}$ & $\mathrm{CaO}$ \\
\hline 90,44 & 4,00 & 0,65 & 4,91 \\
\hline
\end{tabular}


SM dalelių pasiskirstymas pagal dydi pateiktas 2.1 paveiksle. Nustatyta, kad mažesnès nei $10,45 \mu \mathrm{m}$ dydžio dalelès sudarè $50 \%$ SM.

\subsubsection{Metakaolinas}

Metakaolinas (MK) (cheminè formulè $\mathrm{Al}_{2} \mathrm{O}_{3} 2 \mathrm{SiO}_{3}$ ) yra dirbtinè pucolaninè medžiaga, kuri gaminama trimis etapais kaitinant kaolinitą. Pirmuoju etapu $+(60-$ $160)^{\circ} \mathrm{C}$ temperatūroje išgaruoja fiziškai absorbuotas vanduo, antruoju 450 $650{ }^{\circ} \mathrm{C}$ vyksta chemiškai sujungto vandens dehidratacija, trečiuoju etapu vyksta struktūriniai pasikeitimai ir susiformuoja metakaolinas. Jeigu žaliava kaitinama toliau, susidaro mulitas, kurio savybès yra visiškai priešingos.

Darbe naudoto MK cheminè sudètis, \%: $\mathrm{SiO}_{2}-54,7 ; \mathrm{Al}_{2} \mathrm{O}_{3}-44,3 ; \mathrm{Fe}_{2} \mathrm{O}_{3}-$ 0,$4 ; \mathrm{CaO}-0,1 ; \mathrm{MgO}-0,1 ; \mathrm{K}_{2} \mathrm{O}-0,3 ; \mathrm{TiO}_{2}-0,1$. MK dalelių pasiskirstymas pagal dydị pateiktas 2.1 paveiksle. Nustatyta, kad mažesnès nei $6,25 \mu \mathrm{m}$ dydžio dalelès sudarè $50 \% \mathrm{MK}$.

\subsubsection{Cheminès betono įmaišos}

Darbe buvo naudojami trijų tipų SP tirpalai: (SP (A) lignosulfonatų pagrindu, SP (B) poliakrilatu pagrindu, SP (C) polikarboksilatu pagrindu) ir viena orą įtraukianti (OIP) įmaiša Ufapore TCO (2.4 lentelè).

2.4 lentelè. Cheminių betono ịmaišų charakteristikos

Table 2.4 Technical information on chemical admixtures

\begin{tabular}{|l|l|l|l|l|}
\hline Imaišos žymuo & $\mathrm{SP}(\mathrm{A})$ & $\mathrm{SP}(\mathrm{B})$ & $\mathrm{SP}(\mathrm{C})$ & OIP \\
\hline $\mathrm{pH}\left(20^{\circ} \mathrm{C}\right)$ & $7,0 \pm 1,0$ & $7,5 \pm 1,0$ & $4,0-6,0$ & $7,0-9,0$ \\
\hline Tankis, g/cm ${ }^{3}$ & $1,14 \pm 0,03$ & $1,06 \pm 0,02$ & $1,06 \pm 0,01$ & $1,30 \pm 0,05$ \\
\hline Spalva & Tamsi & Geltonai ruda & Ruda & Balta \\
\hline Maks. chloridų kiekis, \% & $\leq 0,05$ & $<0,05$ & $\leq 0,1$ & - \\
\hline Maks. šarmų kiekis, \% & $\leq 6,0$ & $<2,5$ & $\leq 0,1$ & $\leq 1,0$ \\
\hline Sausujų medžiagų kiekis, \% & $31,0 \pm 2,0$ & $27,0 \pm 1,0$ & $27,0 \pm 1,0$ & $92 \pm 2$ \\
\hline Molekulinė masė, g/mol & 35,0 & 39,4 & 51,0 & - \\
\hline Maks. sulfatų kiekis, \% & $\leq 6,0$ & $<0,4$ & $<0,3$ & $\leq 2,0$ \\
\hline $\begin{array}{l}\text { Rekomenduojamas kiekis } \\
\text { nuo cemento masės, \% }\end{array}$ & $0,5-1,0$ & $0,3-2,0$ & $0,3-1,50$ & $0,005-0,05$ \\
\hline
\end{tabular}


Naudojamo OIP komercinis pavadiniams yra „Ufapore TCO“. Tai natrio jonų pagrindu pagaminta aktyvioji paviršiaus medžiaga. Ji veikia kaip orą įtraukianti ir plastifikuojanti įmaiša statybinių medžiagų sudetyse su gipso, cemento ar kalkių rišikliais. „Ufapore TCO“ labai tinka tose vietose, kuriose reikia sumažinti paviršiaus įtempimus ir pagerinti statybinių tešlų savybes.

\subsubsection{Lengvieji užpildai}

Lengvojo kompozito bandiniams formuoti kaip užpildas naudotos dviejų skirtingų frakcijų $(0,5-5 \mathrm{~mm}$, ir $0,18-3 \mathrm{~mm})$ ir skirtingo piltinio tankio $\left(8 \mathrm{~kg} / \mathrm{m}^{3}\right.$ ir $14 \mathrm{~kg} / \mathrm{m}^{3}$ ) PP atliekos (trupintos - PPT, nuopjovos - PPN (2.3 pav.)).

PPT granules pateikè įmonė UAB ,Virginijus ir Co“. Šis užpildas gaminamas smulkintuvu „BIO-50“ trupinant $16-18 \mathrm{~kg} / \mathrm{m}^{3}$ tankio PP atliekų nuolaužas. BIO50 trupintuvą sudaro ant rèmo sumontuoti priešpeiliai ir ant veleno šachmatine tvarka sumontuoti peiliai. Rotorių suka $2,2 \mathrm{~kW}$ elektrinis variklis. PP atliekos specialiu lataku paduodamos ị rotoriaus veikimo zoną ir sutrupinamos. İrenginio našumas - apie $2,0 \mathrm{~m}^{3} / \mathrm{val}$.

PPN susidaro PP gamybos proceso metu, frezuojant PP plokštes ir surenkant smulkiąsias daleles ị tam skirtus filtrus.

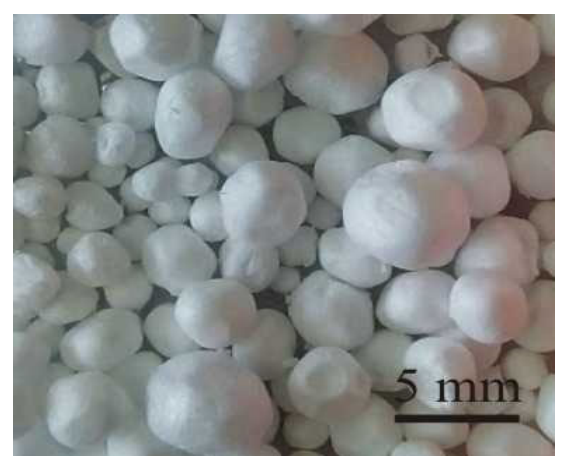

a)

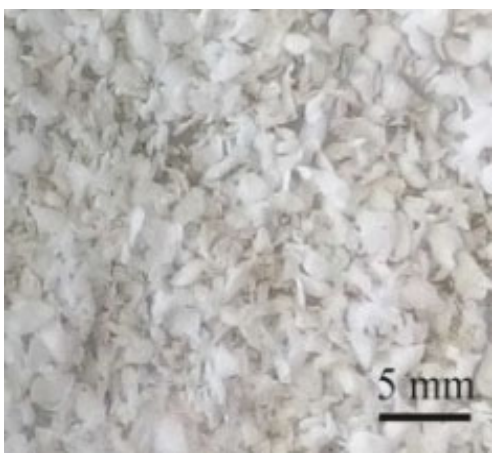

b)

2.3 pav. Polistireninio putplasčio atliekos (didinimas $-\times 5$ ): a) trupintos; b) frezuotos Fig. 2.3. Polystyrene foam waste (magnification $-\times 5$ ): a) crushed; b) milled

PPT ir PPN šilumos laidumo koeficientas nustatytas naudojant prietaisą , $\lambda-$ meter EP500“, jis yra lygus $0,042 \mathrm{~W} / \mathrm{m} \cdot \mathrm{K}$. Granuliometrine sudetis pateikta 2.5 lenteleje. PPT piltinis tankis $-8,00 \mathrm{~kg} / \mathrm{m}^{3}$, PPN piltinis tankis $-14,0 \mathrm{~kg} / \mathrm{m}^{3}$. 
2.5 lentelè. Trupintų ir frezuotų polistireninio putplasčio atliekų granuliometrinè sudètis, masès \%

Table 2.5. The particle size distribution of crushed and milled expanded polystyrene waste, mass $\%$

\begin{tabular}{|c|c|c|c|c|c|c|c|c|c|c|c|}
\hline \multirow{2}{*}{$\begin{array}{l}\text { Pava- } \\
\text { dini- } \\
\text { mas }\end{array}$} & \multicolumn{10}{|c|}{ Likutis ant sieto $(\mathrm{mm}), \%$} \\
\cline { 2 - 12 } & 5,0 & 4,0 & 2,8 & 2,0 & 1,4 & 1,0 & 0,5 & 0,355 & 0,25 & 0,18 & $<0,18$ \\
\hline PPT & 30,0 & 38,0 & 21,0 & 8,0 & 2,0 & 0,5 & 0,5 & - & - & - & - \\
\hline PPN & - & 0,26 & 3,59 & 10,51 & 25,38 & 20,13 & 28,46 & 5,77 & 2,56 & 1,15 & 2,18 \\
\hline
\end{tabular}

2.6 lentelè. Trupintų ir frezuotų polistireninio putplasčio atliekų lengvųjų užpildų vandens sugertis \% po 10, 60 minučių, 7 ir 28 parų, masès $\%$

Table 2.6. Water absorption $\%$ in crushed, and milled expanded polystyrene aggregates after 10, 60 minutes, 7 and 28 days, mass \%

\begin{tabular}{|c|c|c|c|c|}
\hline & 10 min. & 60 min. & 7 paros & 28 paros \\
\hline PPT & 39 & 75 & 90 & 96 \\
\hline PPN & 200 & 320 & 375 & 382 \\
\hline
\end{tabular}

Buvo atlikti PPN PPT sugerties kinetikos tyrimai (2.6 lentelè). Rezultatai parodè, kad PPT struktūra yra mažiau pažeista, o vandens sugertis šiuose agregatuose padidejo nuo $39 \%$ iki $96 \%$ per visą (iki 28 parų) bandymo laikotarpi. PPN atliekų dalelių struktūra yra stipriai pažeista, todèl vanduo užpildo visas jų ertmes ir vandens sugertis bandymo laikotarpiu padidèja nuo $200 \%$ iki $382 \%$.

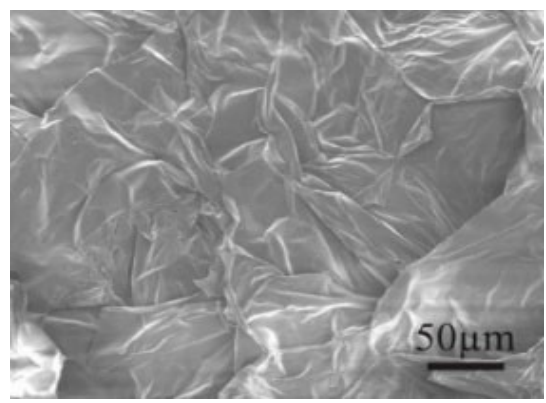

a)

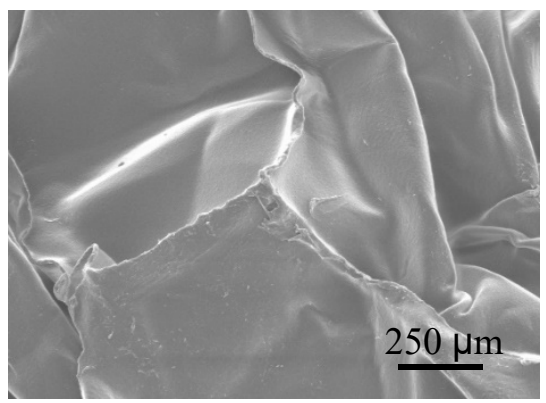

b)

2.4 pav. Frezuotų polistireninio putplasčio dalelių vidinės struktūros vaizdas

a) didinimas 10000 kartu; b) didinimas 50000 kartu

Fig. 2.4. View of milled expanded polystyrene particles structure

a) magnification 10000 times; b) magnification 50000 times 
Tyrime naudotų lengvujų užpildų cheminè sudètis yra vienoda, tačiau jie labai skiriasi vizualiai savo dydžiu ir forma (2.4 pav.), paviršiaus struktūra, nes skiriasi jų paruošimo būdas ir apdorojimas.

Skenuojančiuoju elektroniniu mikroskopu „FEI Helios NanoLab 650“ nustatytas PPN dalelių vidinès struktūros vaizdas pateiktas 2.4 paveiksle, a ir b, kuriame matyti, kad PPN dalelių vidinè struktūra pasižymi dideliu kiekiu skirtingo dydžio oro tuštumų ir ertmių. Šios pastebètos ertmès (kišenès) atsakingos už didelę PPN dalelių vandens sugertį.

\subsection{Daugiasienių anglies nano vamzdelių tirpalo, cemento tešlos ir lengvojo kompozito formavimo mišinių paruošimas bei bandinių formavimas}

\subsubsection{Daugiasienių anglies nano vamzdelių tirpalo paruošimas}

Norint paruošti MWCNTs tirpalą, reikia atitinkamai paruošti „Graphistrength CW2-45" granules. Granulès 15 min. brinkinamos $90-100{ }^{\circ} \mathrm{C}$ temperatūros distiliuotame vandenyje. Išbrinkusios granulès $5 \mathrm{~min}$. disperguojamos dispergatoriumi UZDN-2T, dažnis $22 \mathrm{kHz}, 480 \mathrm{~W}$. Gautas tirpalas maišomas su pagal V/C santykị apskaičiuotu vandens kiekiu (mūsų atveju su $1100 \mathrm{~g}$ vandens) ir naudojamas tyrimams. Pagal PC masę apskaičiuotų Graphistrength CW2-45 granulių kiekis pateiktas 2.7 lentelèje.

2.7 lentelė. Pagal cemento masę apskaičiuotos Graphistrength CW2-45 granulių kiekis Table 2.7. Compositions of samples with Graphistrength CW $2-45$ bundles, mass $\%$

\begin{tabular}{|l|l|l|l|l|}
\hline $\begin{array}{l}\text { Sudèties } \\
\text { žymuo }\end{array}$ & $\begin{array}{l}\text { Granulių kiekis } \\
\text { vandens tirpale, } \\
\mathrm{g}\end{array}$ & $\begin{array}{l}\text { Grynasis } \\
\text { MWCNTs kie- } \\
\text { kis tirpale, g }\end{array}$ & $\begin{array}{l}\text { MWCNTs } \\
\text { koncentracija } \\
\text { tirpaluose, \% }\end{array}$ & $\begin{array}{l}\text { MWCNTs } \\
\text { pagal PC } \\
\text { kiekị, \% }\end{array}$ \\
\hline MWCNTs-1 & 0,0044 & 0,002 & 0,00017 & 0,00005 \\
\hline MWCNTs-2 & 0,0444 & 0,020 & 0,00170 & 0,00050 \\
\hline MWCNTs-3 & 0,4444 & 0,200 & 0,01700 & 0,00500 \\
\hline MWCNTs-4 & 4,4444 & 2,000 & 0,17000 & 0,05000 \\
\hline MWCNTs-5 & 44,444 & 20,00 & 1,70000 & 0,50000 \\
\hline
\end{tabular}




\subsubsection{Bandinių su cementu, daugiasieniais anglies nano vamzdeliais ir plastifikuojančiomis betono ịmaišomis formavimas}

Bandiniams ruošti buvo naudoti PC, MWCNTs tirpalas, SP ir OIP įmaišos bei kambario temperatūros $(20 \pm 2){ }^{\circ} \mathrm{C}$ vanduo. Sudéčių komponentų kiekiai parinkti vadovaujantis gamintojų rekomendacijomis ir literatūros šaltiniais. Suděčių sudarymo schema pateikta 2.5 paveiksle.

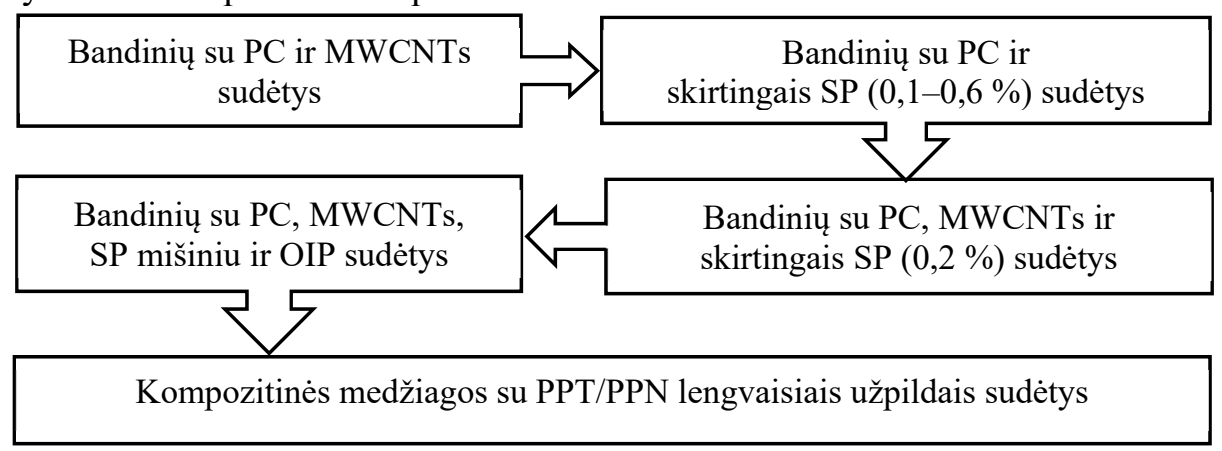

2.5 pav. Sudęčių sudarymo schema

Fig. 2.5. Compositions creation scheme

Norint ịvertinti naudojamos MWCNTs įmaišos kiekio poveikị PC tešlai ir sukietėjusio akmens savybėms, buvo parinktos šešios sudètys (2.8 lentelè). Bandinių maišymo ir formavimo eiga aprašyta toliau.

2.8 lentelè. Bandinių su daugiasieniais anglies nano vamzdeliais sudètys, masės \% Table 2.8. Compositions of samples with multi-walled carbon nano tubes, mass $\%$

\begin{tabular}{|l|l|l|l|l|}
\hline \multirow{2}{*}{ Sudèties žymuo } & \multicolumn{3}{|c|}{ Komponentų kiekis, masės \% } & \multirow{2}{*}{ V/C } \\
\cline { 2 - 4 } & \multirow{2}{*}{ PC } & \multicolumn{2}{|l}{ „Graphistrength CW2-45“ } & \\
\cline { 2 - 4 } & granulès & iš jų MWCNTs & \\
\hline T-0 & 100 & 0 & 0 & 0,3 \\
\hline T-0,00005 & 99,99994 & 0,000061 & 0,00005 & 0,3 \\
\hline T-0,0005 & 99,99939 & 0,000611 & 0,0005 & 0,3 \\
\hline T-0,005 & 99,99389 & 0,006111 & 0,005 & 0,3 \\
\hline T-0,05 & 99,93889 & 0,061111 & 0,05 & 0,3 \\
\hline T-0,5 & 99,38889 & 0,611111 & 0,5 & 0,3 \\
\hline
\end{tabular}


SP įmaišų poveikio PC bandinių savybių tyrimams buvo parinkta 20 sudēčiu (po 6 sudètis su kiekviena SP įmaiša, SP mišiniu ir kontrolinè sudètis) (2.9 lentelè).

2.9 lentelè. Cemento bandinių su plastifikuojančiomis betono įmaišomis sudètys

Table 2.9. Composition of cement samples with plasticizers

\begin{tabular}{|l|l|l|l|l|l|}
\hline $\begin{array}{l}\text { Sudeties } \\
\text { žymuo }\end{array}$ & PC & SP(A)* & SP(B)* & SP(C)* & V/C \\
\hline K-0 & 100 & & & & 0,3 \\
\hline A-0,1 & 100 & 0,1 & & & 0,3 \\
\hline A-0,2 & 100 & 0,2 & & & 0,3 \\
\hline A-0,3 & 100 & 0,3 & & & 0,3 \\
\hline A-0,4 & 100 & 0,4 & & & 0,3 \\
\hline A-0,5 & 100 & 0,5 & & & 0,3 \\
\hline A-0,6 & 100 & 0,6 & & & 0,3 \\
\hline B-0,1 & 100 & & 0,1 & & 0,3 \\
\hline B-0,2 & 100 & & 0,2 & & 0,3 \\
\hline B-0,3 & 100 & & 0,3 & & 0,3 \\
\hline B-0,4 & 100 & & 0,4 & & 0,3 \\
\hline B-0,5 & 100 & & 0,5 & & 0,3 \\
\hline B-0,6 & 100 & & 0,6 & & 0,3 \\
\hline C-0,1 & 100 & & & 0,1 & 0,3 \\
\hline C-0,2 & 100 & & & 0,2 & 0,3 \\
\hline C-0,3 & 100 & & & 0,3 & 0,3 \\
\hline C-0,4 & 100 & & & 0,4 & 0,3 \\
\hline C-0,5 & 100 & & & 0,5 & 0,3 \\
\hline C-0,6 & 100 & & & 0,6 & 0,3 \\
\hline B+C & 100 & & 0,1 & 0,1 & 0,3 \\
\hline
\end{tabular}

*Daugiau nei $100 \%$ sausujų medžiagų kiekio

Sudètinio, SP įmaišų ir MWCNTs poveikio PC bandinių savybių tyrimams buvo parinktos 10 sudèčiu (2.10 lentelè). Pusei sudèčių pasirinktas vienodas MWCNTs ir SP įmaišų kiekis su pastoviu V/C santykiu, kitai pusei, siekiant užtikrinti vienodą sklidumą, V/C buvo mažinamas. 
Norint ịvertinti MWCNTs kiekio ir OIP poveikị PC bandinių su pasirinktu SP mišiniu $(0,1 \% \mathrm{SP}(\mathrm{B})+0,1 \% \mathrm{SP}(\mathrm{C}))$ savybių tyrimams buvo parinktos 5 sudètys (2.11 lentelè).

2.10 lentelè. Cemento bandinių su plastifikuojančiomis betono įmaišomis ir daugiasieniais nano vamzdeliais sudètys, masès \%

Table 2.10. Composition of cement samples with plasticizers and multi-walled carbon nano tubes, mass $\%$

\begin{tabular}{|l|l|l|l|l|l|l|}
\hline $\begin{array}{l}\text { Sudeties } \\
\text { żymuo }\end{array}$ & PC & SP(A)* & SP(B)* & SP(C)* & MWCNTs* & V/C \\
\hline NK & 100 & & & & 0,005 & 0,3 \\
\hline NA & 100 & 0,2 & & & 0,005 & 0,3 \\
\hline NB & 100 & & 0,2 & & 0,005 & 0,3 \\
\hline NC & 100 & & & 0,2 & 0,005 & 0,3 \\
\hline N(B+C) & 100 & & 0,1 & 0,1 & 0,005 & 0,3 \\
\hline WN & 100 & & & & 0,005 & 0,29 \\
\hline WNA & 100 & 0,2 & & & 0,005 & 0,28 \\
\hline WNB & 100 & & 0,2 & & 0,005 & 0,25 \\
\hline WNC & 100 & & & 0,2 & 0,005 & 0,25 \\
\hline WN(B+C) & 100 & & 0,1 & 0,1 & 0,005 & 0,23 \\
\hline
\end{tabular}

*Daugiau nei $100 \%$ sausujų medžiagų kiekio

2.11 lentelè. Cemento bandinių su plastifikuojančių betono įmaišų mišiniu, orą itraukiančia įmaiša ir daugiasieniais nano vamzdeliais sudètys, masès \%

Table 2.11. Composition of cement samples with plasticizers mix, air-entraining, and multi-walled carbon nano tubes, mass \%

\begin{tabular}{|l|l|l|l|l|l|}
\hline Sudeties žymuo & PC & MWCNTs* & SP $(\mathrm{B}+\mathrm{C})^{*}$ & OIP* & V/C \\
\hline M-0SA & 100 & 0 & 0,2 & 0,03 & 0,26 \\
\hline M-1SA & 100 & 0,00005 & 0,2 & 0,03 & 0,26 \\
\hline M-2SA & 100 & 0000,5 & 0,2 & 0,03 & 0,26 \\
\hline M-3SA & 100 & 0,005 & 0,2 & 0,03 & 0,26 \\
\hline M-4SA & 100 & 0,05 & 0,2 & 0,03 & 0,26 \\
\hline M-5SA & 100 & 0,5 & 0,2 & 0,03 & 0,26 \\
\hline
\end{tabular}

* Daugiau nei $100 \%$ sausujų medžiagų kiekio 
PC, MWCNTs tirpalas, SP ir OIP įmaišos buvo maišomos laboratorinëje „Varimixer bear“ maišykleje. Siekiant geresnès homogenizacijos, visas bandymui numatytas vanduo iš pradžių buvo sumaišomas su paruoštu MWCNTs tirpalu. Maišant PC ir MWCNTs tirpalą, pirmas 2 min. buvo maišoma mažesniu (45 aps./min.) greičiu, o likusias 3 min. didesniu (60 aps./min.) greičiu. I PC bandinius su SP sudedami visi komponentai ir maišoma kaip anksčiau aprašyta. Bandiniai su OIP buvo maišomi vertikalia elektrine rankine maišykle, ant kurios uždètas antgalis sparnuotè. I bandinius su OIP iš pradžių buvo dedami MWCNTs tirpalas ir OIP, maišoma 5 min. Po to, įdejjus PC ir SP, dar maišoma 5 min. Maišymo greitis buvo pastovus - 125 aps./min.

PC bandinių hidratacijos procesui stebėti buvo atlikti tyrimai pagal Alcoa metodiką. PC akmens savybèms nustatyti buvo suformuotos $160 \times 40 \times 40 \mathrm{~mm}$ dydžio prizmès. Supilta ị formą tešla $30 \mathrm{~s}$ buvo tankinama naudojant vibracinị stalą, paskui bandiniai dvi paras buvo laikomi uždengti plèvele. Po išformavimo bandiniai dar 26 paras buvo laikomi $(20 \pm 5)^{\circ} \mathrm{C}$ temperatūros vandenyje.

\subsubsection{Lengvojo kompozito formavimas}

Kompozito sudètims buvo pasirinkta modifikuota cementinè matrica ir PPT, PPN lengvieji užpildai. PC matricai modifikuoti kaip sunkusis užpildas, mažinantis džiūstamajị traukumą ir gerinantis granuliometrinę sudètị, buvo panaudotas maltas smèlis. Sudètyje panaudotas MK padidina betono gniuždymo ir tempimo stiprius, ilgaamžiškumą, dilumą, atsparumą cheminèms medžiagoms, taip pat stabilizuoja dideli poretumą turinčių betonų struktūrą (Mlinárik \& Kopecskó, 2013). MK aplinkos temperatūroje reaguoja su $\mathrm{Ca}(\mathrm{OH})_{2}$ ir suformuoja naujus darinius CASH geli, taip pat aliuminio oksido turinčias fazes, tokias kaip $\mathrm{C}_{4} \mathrm{AH}_{13}, \mathrm{C}_{2} \mathrm{ASH}_{8}$ ir $\mathrm{C}_{3} \mathrm{AH}_{6}$. MK dalelès yra mažesnès už cemento, todèl pilnai užpildo smulkias ertmes cemento tešloje. PPT/PPN santykiai buvo parinkti siekiant kuo detaliau ištirti kompozito savybes ir atrasti platesnių pritaikymo galimybių.

Iš viso buvo parinkta 10 suděčiu (2.12 lentelè). PPT ir PPN santykis kito nuo 0 iki 4. Pirmos penkios sudetys yra be MWCNTs, kitos - su vienodu 0,005 \% (nuo PC) MWCNTs kiekiu.

2.12 lentelè. Kompozitu sudètys

Table 2.12. Composite material compositions

\begin{tabular}{|l|l|l|l|l|l|l|l|l|l|l|}
\hline $\begin{array}{l}\text { Kom- } \\
\text { pozito } \\
\text { žymuo }\end{array}$ & MC & MK & $\begin{array}{l}\text { Maltas } \\
\text { smèlis }\end{array}$ & PPT & PPN & $\begin{array}{l}\text { PPT/ } \\
\text { PPN }\end{array}$ & $\begin{array}{l}\text { SP } \\
(\mathrm{B}+\mathrm{C}) \\
*\end{array}$ & OIP* & $\begin{array}{l}\text { MWC } \\
\text { NTs* }\end{array}$ & V/C \\
\hline K1 & 49 & 16,5 & 29,5 & - & 5,0 & $0 / 4$ & 0,2 & 0,025 & - & 0,714 \\
\hline
\end{tabular}


2.12 lentelès pabaiga

\begin{tabular}{|c|c|c|c|c|c|c|c|c|c|c|}
\hline \multirow{2}{*}{$\begin{array}{l}\text { Kom- } \\
\text { pozito } \\
\text { žymuo }\end{array}$} & \multicolumn{5}{|c|}{ Masès \% } & \multirow{2}{*}{$\begin{array}{l}\mathrm{PPT} / \\
\mathrm{PPN}\end{array}$} & \multirow{2}{*}{$\begin{array}{l}\mathrm{SP} \\
(\mathrm{B}+\mathrm{C}) \\
*\end{array}$} & \multirow[b]{2}{*}{ OIP* } & \multirow{2}{*}{$\begin{array}{l}\text { MWC } \\
\text { NTs* }\end{array}$} & \multirow[b]{2}{*}{$\mathrm{V} / \mathrm{C}$} \\
\hline & PC & MK & $\begin{array}{l}\text { Maltas } \\
\text { smélis }\end{array}$ & PPT & PPN & & & & & \\
\hline $\mathrm{K} 2$ & 49 & 16,5 & 29,5 & 1,25 & 3,75 & $1 / 3$ & 0,2 & 0,025 & - & 0,714 \\
\hline K3 & 49 & 16,5 & 29,5 & 2,5 & 2,5 & $2 / 2$ & 0,2 & 0,025 & - & 0,714 \\
\hline K4 & 49 & 16,5 & 29,5 & 3,75 & 1,25 & $3 / 1$ & 0,2 & 0,025 & - & 0,714 \\
\hline K5 & 49 & 16,5 & 29,5 & 5,0 & - & $4 / 0$ & 0,2 & 0,025 & - & 0,714 \\
\hline $\mathrm{K} 1 \mathrm{C}$ & 49 & 16,5 & 29,5 & - & 5 & $0 / 4$ & 0,2 & 0,025 & 0,005 & 0,714 \\
\hline $\mathrm{K} 2 \mathrm{C}$ & 49 & 16,5 & 29,5 & 1,25 & 3,75 & $1 / 3$ & 0,2 & 0,025 & 0,005 & 0,714 \\
\hline $\mathrm{K} 3 \mathrm{C}$ & 49 & 16,5 & 29,5 & 2,5 & 2,5 & $2 / 2$ & 0,2 & 0,025 & 0,005 & 0,714 \\
\hline $\mathrm{K} 4 \mathrm{C}$ & 49 & 16,5 & 29,5 & 3,75 & 1,25 & $3 / 1$ & 0,2 & 0,025 & 0,005 & 0,714 \\
\hline K5C & 49 & 16,5 & 29,5 & 5,0 & - & $4 / 0$ & 0,2 & 0,025 & 0,005 & 0,714 \\
\hline
\end{tabular}

* Daugiau kaip 100 \% sausųjų medžiagų kiekio

Ruošiant kompozito formavimo mišinius, visi komponentai buvo maišomi apvaliame, 401 talpos plastikiniame inde su vertikalia elektrine rankine maišykle, ant kurios uždètas antgalis sparnuote. Maišyklès greitis visų maišymų metu buvo 125 aps./min. Maišymas vyko tokia tvarka: pirmiausia 5 min. buvo maišomi MWCNTs tirpalas ir OIP, paskui maišant sudedama SM, PC ir MK bei SP ir maišoma dar 5 min. Tada ị paruoštą masę supilamas atitinkamas PPN kiekis ir maišoma toliau. Galiausiai dedamos PPT ir maišoma, kol gaunama vienalytė masé. Mišinio homogeniškumas užtikrinamas palaipsniui įdedant medžiagas ir tuo pačiu metu judinant sparnuotę visomis kryptimis, t. y. aukštyn, žemyn, ratu ir i č šonus. Šis maišymo būdas parinktas remiantis kitų tyrejju pateikta informacija ir ypač geras kai naudojami itin maži MWCNTs kiekiai. Šia kompozito mase pildomos formos ir 10 kartu tankinamos mediniu strypu, taip siekiant sutankinti masę, bet kartu nesuardyti poringos struktūros.

Suformuoti bandiniai uždengiami polietileno plèvele ir dvi paras laikomi $(20 \pm 5){ }^{\circ} \mathrm{C}$ temperatūros aplinkoje. Po dviejų parų išformuojami, uždengiami polietileno plèvele ir laikomi 26 paras $(20 \pm 5)^{\circ} \mathrm{C}$ temperatūroje. 


\subsection{Tyrimų metodikos}

\subsubsection{Kompozito komponentu tyrimo metodai}

PPN ir PPT granuliometrinè sudètis buvo nustatyta vadovaujantis standartu LST EN 993-1, panaudojus sietų kratytuvą „Haver \& Boecker“. Sietai atitiko ISO 3310-1 reikalavimus. Piltinis tankis nustatytas pagal standartą LST EN 1097-6.

PPT ir PPN dalelių vandens absorbcija - tai pradinio ir per tam tikrą laikotarpi įmirkusio bandinio masès procentinè išraiška. Atsvertas $50 \mathrm{~g}$ bandinio kiekis, sudètas ị tinklinị narvelị su svareliu, panardinamas vandens vonelëje. Narvelio dydis $-100 \times 100 \times 100 \mathrm{~mm}$, tinklo akutès dydis $-1 \times 1 \mathrm{~mm}$ PPT atveju ir $0,5 \times 0,5 \mathrm{~mm}$ PPN atveju. Vandens lygis virš panardinto narvelio apie $50 \mathrm{~mm}$, vandens temperatūra - apie $23 \pm 5{ }^{\circ} \mathrm{C}$. Praejjus atitinkamam mirkymo laikui narvelis ištraukiamas ir, palaukus apie $10 \mathrm{~min}$, kol nuvarvès vanduo, sveriamas. Absorbcijos tyrimai atlikti po $10,60 \mathrm{~min} ., 7$ ir 28 parų.

MWCNTs tirpalo ir lengvojo kompozito bandinių mikrostruktūros tyrimai atlikti skenuojančiuoju elektroniniu mikroskopu „FEI Helios NanoLab 650“, skiriamoji mikroskopo geba $-0,5 \mathrm{~nm}$.

Smulkiụjų medžiagų PC, SM, MK granuliometrinè sudètis nustatyta lazeriniu granuliometru „Cilas 1090 LD“. Dalelių dydis išmatuotas 0,01-500 $\mu \mathrm{m}$ intervale.

Medžiagų savitasis paviršius nustatomas taikant oro pralaidumo metodą (Bleino metodas) pagal LST EN 196-6:2019 (Cemento bandymo metodai. 6 dalis. Smulkumo nustatymas).

\subsubsection{Tirpalụ ir cemento tešlos tyrimo metodai}

Skirtingu koncentracijų MWCNTs ir SP tirpalų bei PC tešlų su MWCNTs, SP ir OIP klampa ir temperatūra buvo matuojama vibroviskozimetru SV-10, kurio klampos matavimo riba - iki $12000 \mathrm{mPa} \cdot \mathrm{s}$, tikslumas - 0,01 $\mathrm{mPa} \cdot \mathrm{s}$. I specialų tam skirtą indą buvo supilama $45 \mathrm{ml}$ megginio ir įmerkiamos vienodu dažniu judančios plokštelès, fiksuojančios klampos vertes. Klampos ir temperatūros pokyčių matavimų rezultatai buvo fiksuojami iš karto po sumaišymo, praejus $5,10,15,20,25$ ir 30 min.

MWCNTs ir SP tirpalams bei PC tešloms su SP ir MWCNTs buvo atlikti pH ir elektrinio laidumo (EC) matavimai. Šiam tikslui buvo naudojamas prietaisas „Mettler Toledo MPC 227“ ( $\mathrm{pH}$ elektrodas - INLAB 410, matavimo tikslumas 0,01 ; elektrinio laidumo elektrodas - INLAB 730 , matavimo ribos - nuo $0 \mathrm{mS} / \mathrm{cm}$ iki $1000 \mathrm{mS} / \mathrm{cm}$ ). MWCNTs ir SP tirpalų bei PC tešlų klampos, EC ir pH matavimai buvo atliekami kambario $(20 \pm 5)^{\circ} \mathrm{C}$ temperatūroje. Bandymai buvo atlikti iš karto po sumaišymo, praejjus $5,10,15,20,25$ ir $30 \mathrm{~min}$.

MWCNTs bei SP įmaišų kiekio ir tipo poveikis PC tešlos reologinėms savybėms buvo nustatomas atliekant sklidumo bandymą. Sklidumas buvo nustatytas 
naudojant Viko kūgi (aukštis - $40 \mathrm{~mm}$, viršutinis skersmuo - $70 \mathrm{~mm}$, apatinis skersmuo $-80 \mathrm{~mm}$ ). Maišyklèje sumaišyta PC tešla dviem sluoksniais, kiekvieną jų 10 kartų sutankinant metaliniu $2 \mathrm{~mm}$ skersmens strypeliu, buvo sukrèsta $\mathfrak{i}$ formą, padètą kratymo stalelio stiklinio disko centre. Vèliau forma buvo nuimta ir ant stiklo paviršiaus pasilikusi tešla 15 kartų sukratoma pastoviu dažniu 1 aps./s. Tešla pasklinda ant stiklinès plokštès, liniuote matuojamas pasklidimo skersmuo.

Skirtingo MWCNTs kiekio poveikis PC tešlos rišimosi trukmei buvo nustatytas Viko prietaisu.

PC tešlos EXO proceso tyrimai atlikti pagal firmos „Alcoa“ sukurtą metodiką. PC tešlos atveju buvo naudojamas $1,5 \mathrm{~kg}$ sveriantis bandinys. Masė suklojama 100×100×100 mm dydžio tekstolito formoje. Formuojant ị bandinị ịstatoma stikliniame vamzdelyje esanti $\mathrm{T}$ tipo termopora, sujungta su duomenų kaupimo sistema. Temperatūros pokyčiai registruojami kaip laiko funkcija. Kol vyksta šilumos išsiskyrimas bandinyje, temperatūros kitimo eiga vieną kartą per $1 \mathrm{~min}$. nepertraukiamai užrašinèjama kompiuteryje. Tyrimas vyko pastovioje $(20 \pm 1){ }^{\circ} \mathrm{C}$ temperatūros aplinkoje.

PC tešlos struktūros formavimosi tyrimas atliktas prietaisu „Pundit 7“ (keitiklių dažnis - $54 \mathrm{kHz}$ ). Ultragarso impulsų greičio (UIG) vertès buvo matuojamos PC tešloje iškarto po sumaišymo, taip pat ir sukietejjusiuose PC akmens ir kompozito bandiniuose. UIG bandymai parodo bandinių struktūros formavimąsi rišimosi metu (Trtnik et al., 2008) ir iš esmès koreliuoja su gniuždymo stiprio rezultatais. Iš karto po sumaišymo PC tešla buvo supilta į specialų tekstolitinị žiedą, jis padedamas tarp dviejų ultragarso daviklių, sujungtų su duomenų kaupimo sistema. Struktūros pokyčiai (signalo sklidimo laikas) registruojami kaip laiko funkcija 1 parą (24 val.). Tyrimas buvo vykdomas $(20 \pm 1){ }^{\circ} \mathrm{C}$ temperatūros aplinkoje. Sukietejusio PC akmens ir kompozito bandinių struktūros susidarymo pokyčiai buvo tirti po 2, 7 ir 28 bandinių kietejjimo parų. UIG apskaičiuotas pagal 2.1 formulę:

$$
V=\frac{l}{\tau} 10^{6},
$$

čia $V$ - ultragarso impulsu greitis, $\mathrm{m} / \mathrm{s} ; \tau$ - signalo sklidimo laikas, $\mathrm{s} ; l$ - testuojamo bandinio ilgis (tarpas tarp cilindro galvučių), $\mathrm{m}$.

\subsubsection{Sukietèjusio cemento akmens tyrimai}

Buvo atlikti sukietejusio PC akmens bandinių su MWCNTs ir SP XRD tyrimai. Tyrimui panaudotas rentgeno spinduliu difraktometras DRON-7, kurio antikatodas - varinis, filtras - nikelinis, anodo ịtampa $-30 \mathrm{kV}$, anodo srove - $12 \mathrm{~mA}$, goniometro plyšeliai - $0,5 \mathrm{~mm}, 1,0 \mathrm{~mm}$ ir $1,5 \mathrm{~mm}$. Smailèms iššifruoti buvo naudojama ICDD duomenų bazè. 
Sukietejusiems PC akmens bandiniams su MWCNTs ir SP buvo atliktas terminès analizès DTA/TG tyrimas, naudojant derivatografą „Linseis STA PT$1600^{“}$. Temperatūra buvo keliama iki $1000{ }^{\circ} \mathrm{C}$, temperatūros kilimo greitis $10^{\circ} \mathrm{C} / \mathrm{min}$., šildymo aplinka - oras, mèginių masè $-50 \pm 5 \mathrm{mg}$.

Sukietejusių PC akmens bandinių su MWCNTs, SP ir OIP bei kompozito bandinių vandens sugertis nustatyta po 28 parų kietejjimo, vadovaujantis LST EN 12087:2013 standarto A metodu. Bandyta po penkis $100 \times 100 \times 100 \mathrm{~mm}$ dydžio kiekvienos sudèties bandinius. Bandiniai išimami po $5,10,15,30,60,90 \mathrm{~min}$. ir $24 \mathrm{~h}$ dedami ant specialaus tam skirto tinklelio $45^{\circ} \mathrm{kampu}$, sausinami apie $(10 \pm 0,5)$ min. ir sveriami. Vandens sugertis apskaičiuota pagal 2.2 formulę:

$$
W_{i}=\frac{m_{i}-m_{0}}{V} \times \frac{100}{\rho_{w}}, \%,
$$

čia $W_{i}$ - vandens sugertis; $m_{i}$ - per laiko tarpą įmirkyto vandenyje bandinio masè, $\mathrm{kg} ; m_{0}$ - pradinè bandinio masè, $\mathrm{kg} ; V$ - bandinio tūris, $\mathrm{m}^{3} ; \rho_{w}$ - vandens tankis $1000 \mathrm{~kg} / \mathrm{m}^{3}$.

Sukietejusio PC akmens atvirasis (kapiliarinis) poringumas apskaičiuojamas pagal 2.3 formulę:

$$
P_{a}=W_{v} \times \frac{\rho_{c}}{1000}
$$

čia $P_{a}$ - atvirasis PC akmens poringumas, $\% ; W_{v}$ - visiškoji PC akmens vandens sugertis, $\% ; \rho_{\mathrm{c}}-\mathrm{PC}$ matricos tankis, $\mathrm{kg} / \mathrm{m}^{3}$.

PC akmens bandinių su MWCNTs, SP ir OIP mikrostruktūros tyrimai buvo atlikti naudojant lauko emisijos skenuojantijji elektroninį mikroskopą su rentgeno spindulių energijos dispersijos spektrometru SEM JEOL JSM-7600F, kurio skiriamoji geba yra 1,5 nm, didinimas - nuo 25 iki 1000000 kartu, o bandymo metu naudota $10 \mathrm{kV}$ ịtampa. Bandiniai prieš eksperimentą nebuvo dengiami.

MWCNTs tirpalo ir lengvojo kompozito bandinių mikrostruktūros tyrimai atlikti skenuojančiuoju elektroniniu mikroskopu „FEI Helios NanoLab 650“, skiriamoji mikroskopo geba $-0,5 \mathrm{~nm}$. Prieš tyrimą lengvojo kompozito bandiniai buvo rankomis laužiami ir padengiami anglies sluoksniu. Tyrimo metu buvo fotografuojami matricos sąlyčio zonų tarp matricos ir intarpų paviršiai.

Sukietejusių PC akmens bandinių gniuždymo ir lenkimo stipriai po 2, 7 ir 28 parų kietejjimo nustatyti hidrauliniu presu „Tinus Olsen 20KU“. Lenkimui bandyta po tris $160 \times 40 \times 40 \mathrm{~mm}$ dydžio kiekvienos sudėties bandinius. Gniuždymo stipriui nustatyti bandyta po šešias perlaužtas kiekvienos sudèties prizmių puseles. Bandymai atlikti vadovaujantis standartu LST EN 196-1:2016 (Cemento bandymų metodai. 1 dalis. Stiprio nustatymas). 


\subsubsection{Lengvojo kompozito bandinių tyrimo metodai}

Lengvojo kompozito bandinių tankis buvo nustatytas pagal LST EN 1602. Bandyta po penkis $100 \times 100 \times 100 \mathrm{~mm}$ dydžio bandinius.

Kompozito bandinių gniuždymo stipris nustatytas hidrauliniu presu „Tinus Olsen $20 \mathrm{KU}$ “. İrenginio pastūmos mechanizmo greitis bandymo metu $-10 \mathrm{~mm} / \mathrm{min}$.

Lengvojo kompozito bandinių šilumos laidumo koeficientas $\left(\lambda_{10}\right)$ nustatytas naudojant prietaisą „LaserComp FOX 304“. Prietaiso matavimo ribos - 0,01$0,50 \mathrm{~W} /(\mathrm{m} \cdot \mathrm{K})$, matavimu tikslumas - apie $1 \%$. Bandinio matmenys $300 \times 300 \times 50 \mathrm{~mm}$, plokštumos nušlifuotos abrazyviniu disku. Bandinio paviršių temperatūrų skirtumas $-10^{\circ} \mathrm{C}$. Prieš testuojant bandiniai džiovinti $(70 \pm 2){ }^{\circ} \mathrm{C}$ temperatūroje iki pastovios masès. Bandyta po vieną kiekvienos sudèties termoizoliacinio kompozito bandinị.

Kapiliarinès sugerties koeficientas $\left(c_{w, s}\right)$ nustatytas vadovaujantis LST EN 772-11:2011 standartu. Tirta po tris $100 \times 100 \times 100 \mathrm{~mm}$ dydžio bandinius. Prieš bandymą bandiniai buvo džiovinami iki pastovios masès ventiliuojamoje džiovykloje SNOL, $(70 \pm 5)^{\circ} \mathrm{C}$ temperatūros aplinkoje. Kapiliarinès sugerties koeficientui nustatyti bandiniai buvo sudèti ant atraminès $10 \mathrm{~mm}$ pakylos, panardinti ị

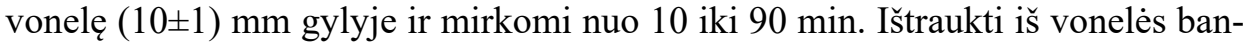
diniai buvo nuvalomi medžiagine servetèle ir sveriami kas $10 \mathrm{~min}$.

Bandinių pralaidumas vandens garams nustatytas pagal LST EN 12086:2013. Bandyta po tris $100 \times 100 \times 50 \mathrm{~mm}$ dydžio kiekvienos sudèties bandinius. Vidutinis oro slègis bandymo metu $-1013 \mathrm{hPa}$, santykinè drègmè $50 \pm 2 \%$, oro temperatūra $23 \pm 1{ }^{\circ} \mathrm{C}$. Vandens garų srauto tekejjimo kryptis buvo statmena bandinių formavimo paviršiui.

Lengvojo kompozito bandinių džiūstamojo traukumo dydžiai nustatyti pagal LST EN 772-14:2003. Bandyta po šešis $160 \times 40 \times 40$ mm dydžio kiekvienos sudèties bandinius. Kompozito bandinių ilgio pokytis matuotas skaitmeniniu prietaisu „Matest“, kurio skalès tikslumas - 0,001 mm.

\subsection{Antrojo skyriaus išvados}

1. Nustatyta, kad naudojamų trupintų ir frezuotų polistireninio putplasčio atliekų granuliometrinè sudėtis yra skirtinga. Trupintoje polistireninio putplasčio atliekoje vyrauja stambesnès dalelès, o frezuotoje - smulkesnès. Bendras jų naudojimas kompozite gali užtikrinti kompaktišką kuriamo kompozito struktūrą.

2. Darbe naudojamos cheminès įmaišos pasižymi skirtingomis $\mathrm{pH}$ ir elektrinio laidumo vertèmis vandens tirpale, o tai gali leisti reguliuoti cemento hidratacijos procesą. 
3. Siekiant ištirti cemento tešlos, modifikuotos daugiasieniais anglies nano vamzdeliais ir cheminėmis įmaišomis hidratacijos procesus, buvo parinkti konduktometrijos, $\mathrm{pH}$, klampos, egzoterminès reakcijos, ultragarso impulso sklidimo tešloje kietejjimo metu, tyrimo metodai.

4. Elektroninè mikroskopija, rentgeno spindulių difrakcijos ir termogravimetrinè analizè leidžia ištirti cemento akmens, modifikuoto daugiasieniais anglies nano vamzdeliais ir cheminèmis įmaišomis, hidratacijos produktus pagal jų morfologiją ir mineralinès sudèties pokyčius.

5. Parinktos tyrimų metodikos (šilumos laidumo koeficiento, pralaidumo vandens garams, džiūstamojo traukumo) leidžia ịvertinti cemento akmens, modifikuoto daugiasieniais anglies nano vamzdeliais ir cheminèmis įmaišomis poveikị lengvojo kompozito eksploatavimo savybèms. 



\section{Modifikuotų daugiasieniais anglies nano vamzdeliais ir cheminèmis betono ịmaišomis cemento tešlų, akmens ir lengvojo kompozito su polistireninio putplasčio atliekomis tyrimai}

Šiu tyrimų tikslas - nustatyti MWCNTs tirpalo savybes, įvertinti MWCNTs bei cheminių betono ịmaišu poveikị modifikuotos PC tešlos reologinèms savybėms, hidratacijos procesui, $\mathrm{PC}$ akmens fizikinèms ir mechaninèms savybèms bei struktūrai. Parinkti optimalią modifikuoto PC akmens sudètí, užtikrinančią geriausias sukietejusio PC akmens mechanines savybes. Sukurti lengvaji kompozitą iš optimizuotos PC matricos bei dviejų atliekinių užpildų (PPT ir PPN), naudojamų skirtingu santykiu, ir ištirti jo struktūrą, fizikines ir mechanines savybes. Tyrimų eigos schema pateikta 3.1 paveiksle. 
MWCNTs tirpalų tyrimai

SP tirpalų tyrimai

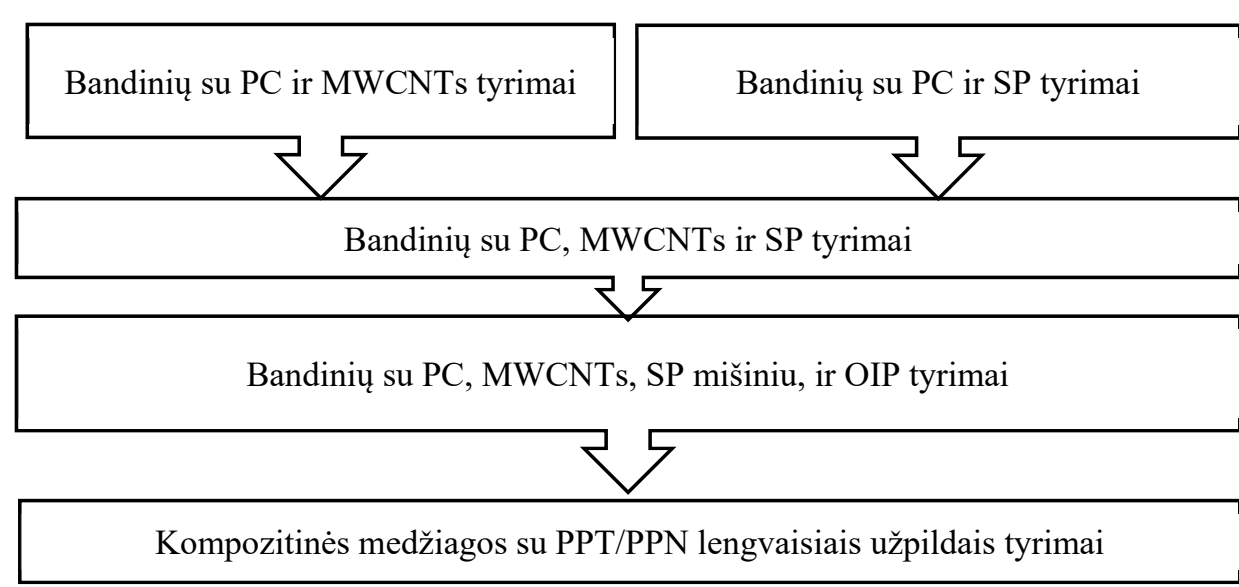

3.1 pav. Tyrimų eigos schema

Fig. 3.1. Research process flow chart

Skyriaus tematika paskelbti 7 autoriaus straipsniai (Leonavičius et al., 2017, 2018, 2019a, 2019b, 2019c, 2019d, 2020).

\subsection{Daugiasienių anglies nano vamzdelių poveikio cemento tešlai ir akmeniui tyrimai}

\subsubsection{Daugiasienių anglies nano vamzdelių tirpalų tyrimai}

Norint ịvertinti MWCNTs kiekio poveikị MWCNTs tirpalų dinaminei klampai, $\mathrm{EC}$ ir $\mathrm{pH}$, buvo atlikti MWCNTs tirpalų tyrimai. Dinaminiai MWCNTs tirpalų klampos matavimai rodo (3.1 lentelè), kad nedideli (0,00017-0,017\%) MWCNTs kiekiai sumažina klampą iki $15 \%$, didesnis kiekis $(0,17 \%)$ padidina klampą iki $30 \%$, o maksimalus kiekis (1,7 g), palyginus su gryno distiliuoto vandens, padidina klampą 4,7 karto. Šiems pokyčiams taip pat ịtakos gali turèti karboksilmetilceliuliozè (vandens tirpaluose ji veikia kaip tirštiklis), kuri naudojama „Graphistrength CW2-45“ granulių gamybos technologijoje. Tačiau vandens tirpaluose, kuriuose yra nedidelis MWCNTs kiekis, vyksta priešingi procesai, dinaminė klampa mažèja. Yra žinoma, kad EC priklauso nuo jonų kiekio vandens tirpale. 
Tyrimų rezultatai rodo, kad didejjantis MWCNTs kiekis vandens tirpaluose padidina EC nuo $15 \times 10^{-4}$ iki $245 \times 10^{-4} \mu \mathrm{S} / \mathrm{cm}$, atitinkamai $\mathrm{pH}$ kinta nuo 6,89 iki 5,7, kai gryno distiliuoto vandens $\mathrm{pH}$ yra 5,8 .

3.1 lentelè. Tirpalų su skirtingais daugiasienių anglies nano vamzdelių kiekiais dinaminė klampa, $\mathrm{pH}$ ir elektrinis laidumas

Table 3.1. Dynamic viscosity, $\mathrm{pH}$, and electrical conductivity in water solutions with different amounts of multi-walled carbon nano tubes

\begin{tabular}{|l|l|l|l|l|}
\hline Sudèties žymuo & $\begin{array}{l}\text { MWCNTs kiekis } \\
\text { vandens tirpale, } \%\end{array}$ & Klampa, MPa·s & $\mathrm{pH}$ & $\mathrm{EC}, \mu \mathrm{S} / \mathrm{cm}$ \\
\hline MWCNTs-0 & - & 0,74 & 6,89 & $15 \times 10^{-4}$ \\
\hline MWCNTs-1 & 0,00017 & 0,68 & 6,75 & $83 \times 10^{-4}$ \\
\hline MWCNTs-2 & 0,00170 & 0,65 & 6,60 & $98 \times 10^{-4}$ \\
\hline MWCNTs-3 & 0,01700 & 0,63 & 6,42 & $125 \times 10^{-4}$ \\
\hline MWCNTs-4 & 0,17000 & 0,96 & 6,07 & $159 \times 10^{-4}$ \\
\hline MWCNTs-5 & 1,70000 & 3,5 & 5,78 & $245 \times 10^{-4}$ \\
\hline
\end{tabular}

Galima teigti, kad MWCNTs granulès nèra visiškai inertiška medžiaga. Granulèse esantis rišiklis karboksilmetilceliuliozė po ultragarsinio apdorojimo karštame vandenyje tirpsta ir daro įtaką tirpalo EC ir pH. Yra žinoma, kad karboksimetilceliuliozè yra silpna rūgštis, dèl kurios gali sumažèti pH. Kaip nurodo Karpova (2020) savo tyrime, karboksimetilceliuliozė stabdo cemento hidrataciją.

\subsubsection{Skenuojančiosios elektroninès mikroskopijos tyrimai}

Norint ịvertinti, kaip MWCNTs priklausomai jo nuo kiekio tirpale pasiskirsto po ultragarsinio apdorojimo, buvo atlikti SEM tyrimai (3.2 pav.). Tyrimams buvo atrinkti trys bandiniai, kurių tirpaluose MWCNTs koncentracija sudarè $0,00017 \%, 0,017 \%$ ir 1,7\%. Matome, kad kai tirpale yra minimalus MWCNTs kiekis, didelè dalis MWCNTs plaušelių neatsiskiria nuo rišiklio (karboksilmetilceliuliozès). Kai MWCNTs koncentracija tirpale siekia 0,017\%, pastebima, kad MWCNTs plaušeliai daug geriau atsiskiria nuo rišiklio, nedisperguotų rišiklio fragmentų pastebima mažiau. 


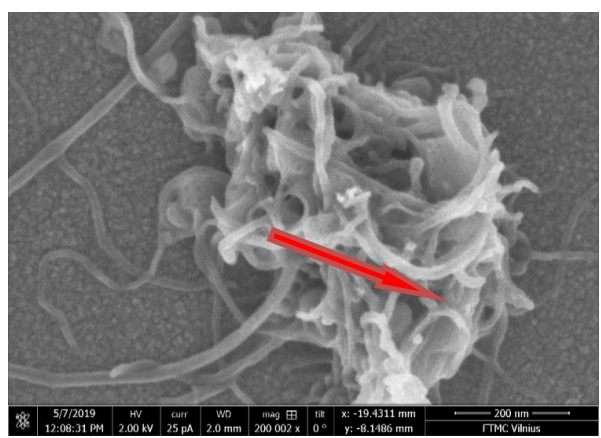

a)

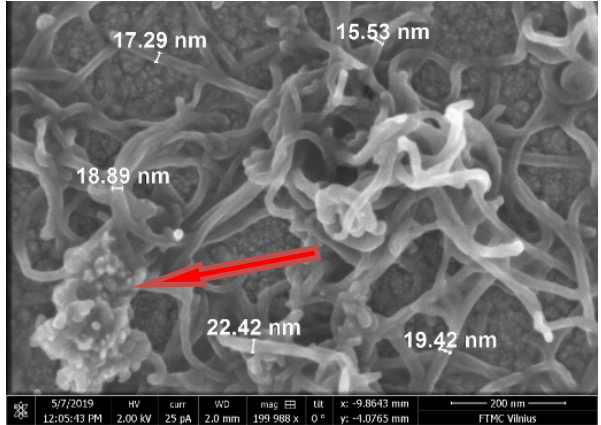

b)

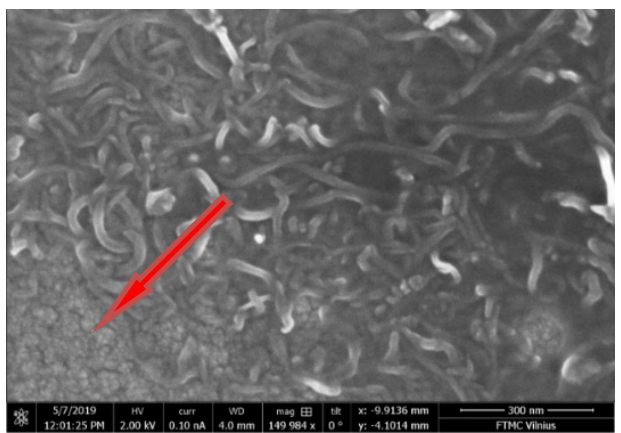

c)

3.2 pav. Skirtingos koncentracijos daugiasienių anglies nano vamzdelių tirpalo skenuojančios elektroninès mikroskopijos vaizdai: a) $0,00017 \%$ didinimas $\times 200000$;

b) $0,017 \%$ didinimas $\times 200000$; c) $1,7 \%$ didinimas $\times 150000$

Fig. 3.2. Scanning electron microscopy pictures of different concentrations multi-walled carbon nano tubes solutions: a) $0,00017 \%$ magnification $-\times 200000$; b) $0,017 \%$ magnification $-\times 200000$; c) $1,7 \%$ magnification $-\times 150000$

Kai tirpale yra maksimali, t. y. 1,7\%, MWCNTs koncentracija, matomas didžiulis tarpusavyje neatskirtų MWCNTs plaušelių kiekis, taip pat pastebimi ir dideli nedisperguoto rišiklio fragmentai. SEM tyrimai leidžia įvertinti MWCNTs plaušelių storị, kuris svyruoja 15-22 nm.

\subsubsection{Cemento tešlos dinaminè klampa}

Skirtingo MWCNTs kiekio PC tešloje (3.3 pav.) poveikio tyrimai parodè, kad didžiausią dinaminę klampą (2100 MPa·s, po $30 \mathrm{~min}$.) turi kontrolinis bandinys (T-0). Naudojant minimalius MWCNTs kiekius (0,00005 ir 0,0005\%), pradinè šviežių PC tešlų dinaminè klampa sumažèjo apytiksliai iki $31 \%$, lyginant su kont- 
roline T-0 tešla, ir siekė $400 \mathrm{MPa} \cdot \mathrm{s}$ vertę. Tarp šių dviejų PC tešlų suděčių dinaminès klampos po 20 min. praktiškai nèra jokio skirtumo. T-0,00005 bandinio klampa po $30 \mathrm{~min}$. siekia $1605 \mathrm{MPa} \cdot \mathrm{s}$, o bandinio T-0,0005 - $1850 \mathrm{MPa} \cdot \mathrm{s}$.

Mažiausia dinaminè klampa nustatyta bandinio T-0,005 - per 30 min. pakito nuo 430 iki $690 \mathrm{MPa} \cdot \mathrm{s}$. Bandinio T-0,05 klampa didejjo panašiai kaip ir T-0,005 bandinio klampa ir po $30 \mathrm{~min}$. pasiekè $730 \mathrm{MPa} \cdot \mathrm{s}$ vertę. Esant maksimaliam $(0,5 \%)$ MWCNTs kiekiui bandinyje, dinaminè klampa sparčiai didejjo, iš karto po sumaišymo pasiekė $660 \mathrm{MPa} \cdot \mathrm{s}$, o po $30 \mathrm{~min}$. - ir $920 \mathrm{MPa} \cdot \mathrm{s}$.

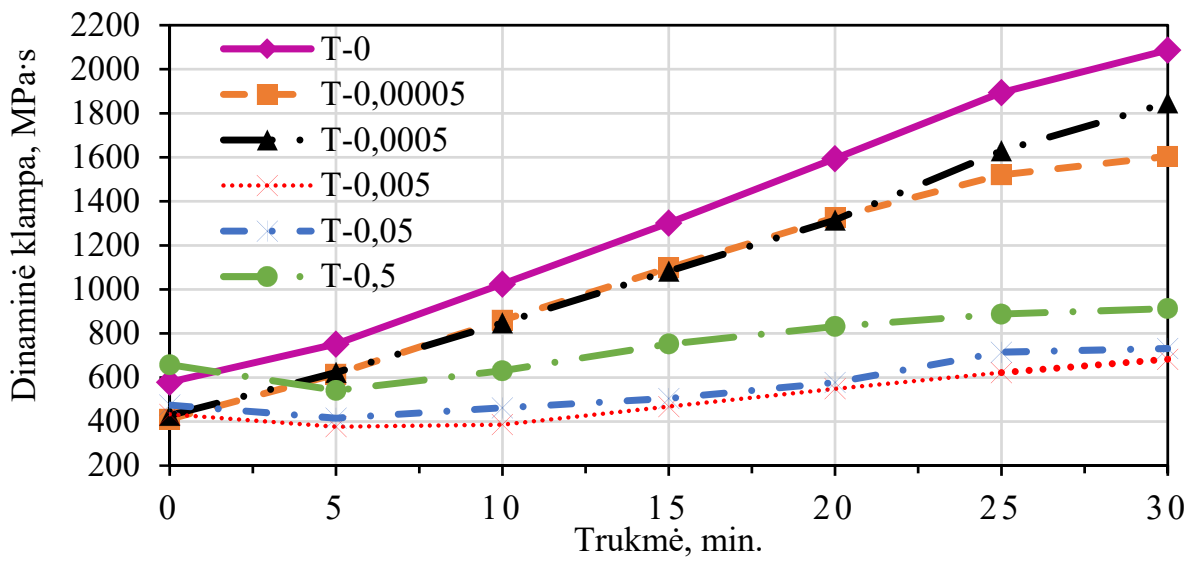

3.3 pav. Daugiasienių anglies nano vamzdelių kiekio poveikis cemento tešlos dinaminei klampai

Fig. 3.3. Dynamic viscosity of the fresh cement pastes, depending on the amount of multi-walled carbon nano tubes

Galima daryti išvadą, kad PC tešloje labiausiai dinaminę klampą mažina 0,005 ir $0,05 \%$ MWCNTs kiekiai.

\subsubsection{Cemento tešlos elektrinis laidumas ir pH}

EC ir pH matavimai šviežiose PC tešlose padeda apibūdinti MWCNTs ịtaką hidratacijos eigai, tirpstant cemento mineralams. Per 15 min. sparčiai padidèjęs EC parodè PC mineralų tirpimo procesą ir jonų perèjimą ị tirpalą. MWCNTs daro didžiausią poveikị būtent šiame etape, nes toliau EC stabilizuojasi dèl pusiausvyros.

Kontrolinio T-0 bandinio EC 30 min. laikotarpiu padideja nuo 15,5 iki $18,4 \mathrm{mS} / \mathrm{cm}$ (3.4 pav.). Matavimo pradžioje visų bandinių su MWCNTs EC, palyginus su kontroliniu bandiniu be MWCNTs, yra šiek tiek mažesnis (nuo 15,3 iki 
$14,6 \mathrm{mS} / \mathrm{cm})$. Tačiau mažesni MWCNTs kiekiai $(0,00005$ ir $0,0005 \%)$ turi mažesnę ịtaką pradiniam PC tešlos EC (atitinkamai 15,3 ir 15,25 mS/cm).

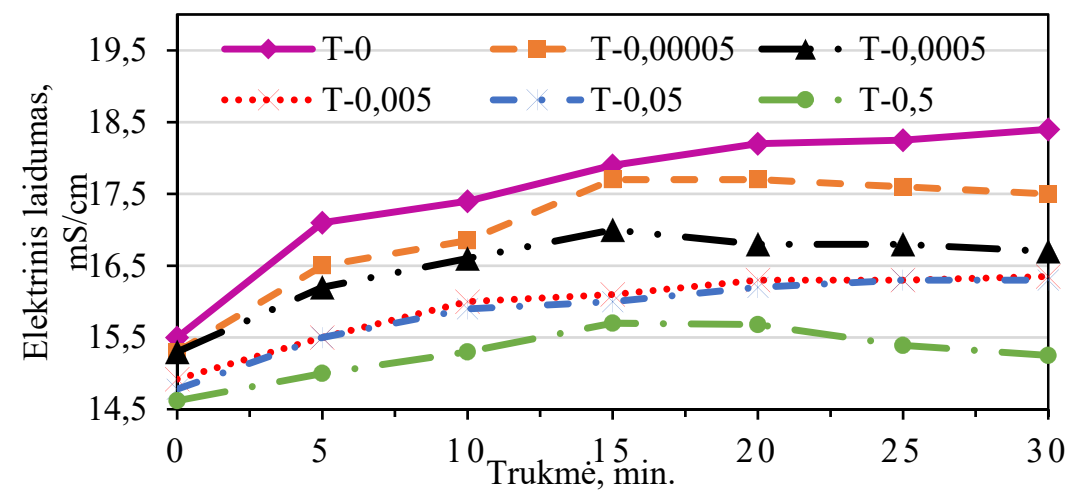

3.4 pav. Daugiasienių anglies nano vamzdeliụ kiekio poveikis cemento tešlos elektriniam laidumui

Fig. 3.4. Electrical conductivity of the fresh cement pastes, depending on the amount of multi-walled carbon nano tubes

Didesnis MWCNTs kiekis PC tešloje sumažina EC apie 5\%-iki $14,6 \mathrm{mS} / \mathrm{cm}$. EC skirtumas tarp kontrolinio ir bandinio su didžiausiu MWCNTs kiekiu yra 3,2 mS/cm (apytiksliai $17 \%$ ). Šie rezultatai parodo, kad MWCNTs mažina PC tešlų EC ir sulètina cemento mineralų hidrataciją.

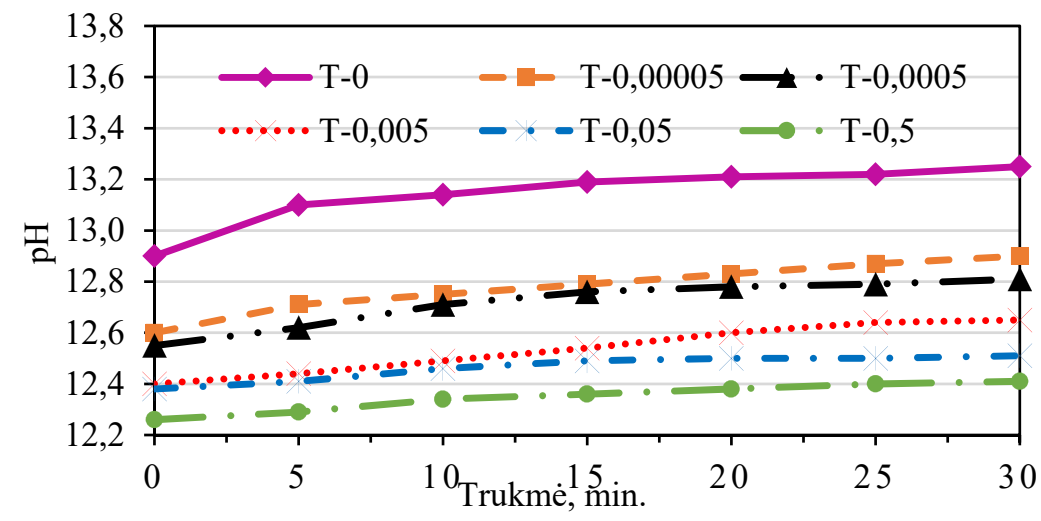

3.5 pav. Daugiasienių anglies nano vamzdelių kiekio poveikis cemento tešlos $\mathrm{pH}$

Fig. 3.5. $\mathrm{pH}$ of the fresh cement pastes, depending on the amount of multi-walled carbon nano tubes 
PC tešlų pH matavimai (3.5 pav.) rodo, kad kontroliniame T-0 bandinyje 30 min. laikotarpiu pH vertès padidèja nuo 12,9 iki 13,3. Kai MWCNTs kiekis didinamas (nuo 0,00005 iki $0,5 \%$ ), stebima, kad iš karto po sumaišymo tešlų pH mažeja nuo 12,6 iki 12,26. Panašiai, kaip ir atliekant EC tyrimus, pastebèta, kad mažesni MWCNTs kiekiai $(0,00005$ ir 0,0005 \%) turi mažesnę įtaką pradinèms PC tešlų $\mathrm{pH}$ vertėms, o didesni MWCNTs kiekiai pastebimai mažina PC tešlų $\mathrm{pH}$. Matoma panaši tendencija kaip ir EC bandymuose - kuo mažesnis MWCNTs kiekis PC tešlose, tuo didesnès $\mathrm{pH}$ vertès yra po $30 \mathrm{~min}$. Kontrolinio ir didžiausio MWCNTs kiekio bandinių $\mathrm{pH}$ skirtumas yra 0,9 , t. y. didesnis MWCNTs kiekis gali sumažinti PC tešlos pH iki 6,8 \%, o skirtumas tarp bandinių su minimaliais ir maksimaliais MWCNTs kiekiais sudarè 0,5.

Mažesnis PC tešlų EC ir pH parodè, kad MWCNTs lètina pradinę cemento mineralų hidrataciją. PC tešlų dinaminès klampos, $\mathrm{pH}$ ir EC matavimų rezultatai koreliavo. Didèjant MWCNTs kiekiui, mažèja PC tešlų EC, pH ir dinaminè klampa. Tačiau dinaminè klampa mažèja tik iki tam tikrų ribų (tokia pati tendencija buvo vandens tirpaluose su MWCNTs).

\subsubsection{Cemento tešlos rišimosi laikas}

PC tešlų su MWCNTs rišimosi laiko pradžios ir pabaigos tyrimų rezultatai parodė, kad nuo 0,00005 \% iki 0,0005 \% padidèjęs MWCNTs kiekis rišimosi pradžios laikui praktiškai neturi ịtakos (3.6 pav.). Padidèjęs iki 0,005 \% MWCNTs kiekis pailgina PC tešlos rišimosi pradžios laiką nuo 150 iki 194 min., o didesni MWCNTs kiekiai $(0,05 \%$ ir 0,5\%) - iki 228 ir $357 \mathrm{~min}$.

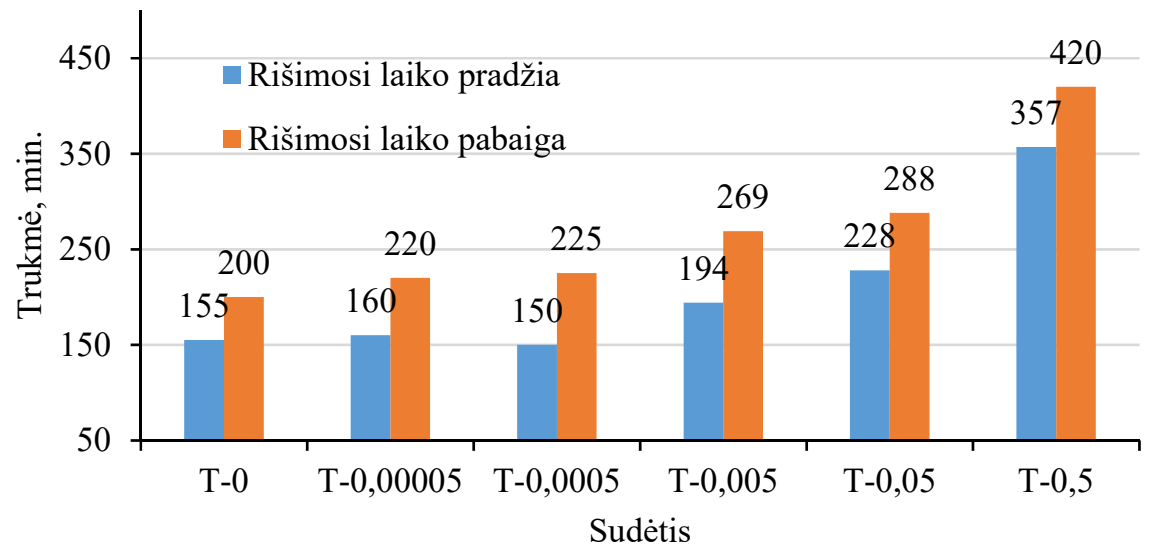

3.6 pav. Daugiasienių anglies nano vamzdelių kiekio poveikis cemento tešlų rišimosi pradžios ir pabaigos laikui

Fig. 3.6. Initial setting time of the cement pastes depending on the amount of multi-walled carbon nano tubes 
Rišimosi pabaigos laiko tyrimų rezultatai parodè, kad PC tešlose didèjantis MWCNTs kiekis ilgina rišimosi pabaigos laiką (nuo 200 iki 420 min). Ženklus rišimosi pabaigos laiko padidejjimas pastebètas sudetyje su maksimaliu $0,5 \%$ MWCNTs kiekiu - iki 420 min. Tai taip pat liudija, kad, didinant MWCNTs kieki PC tešlose, labai lèteja cemento hidratacija.

\subsubsection{Cemento tešlos egzotermijos reakcija}

EXO reakcijos temperatūros pokyčiai laiko atžvilgiu atspindi PC tešlų hidratacijos eigą. Siekiant ịvertinti, kaip PC tešlose esantys MWCNTs kiekiai veikia išsiskiriančios šilumos dydị, buvo atlikti EXO tyrimai (3.7 pav.). Kontrolinio T-0 bandinio tyrimai parodè, kad maksimali EXO temperatūra siekè $+87^{\circ} \mathrm{C}$. Minimalus ir maksimalus MWCNTs kiekis $(0,00005 \%$ ir $0,5 \%)$ sumažino EXO temperatūrą $4{ }^{\circ} \mathrm{C}$ ir $16{ }^{\circ} \mathrm{C}(20 \%)$, t. y. didinant MWCNTs kiekị maksimali EXO temperatūra mažèja nuo $82^{\circ} \mathrm{C}$ iki $71^{\circ} \mathrm{C}$. Didžiausi temperatūros pokyčiai pastebèti tų bandinių, kurių MWCNTs kiekiai yra 0,05 \% iki 0,5\%. Šie rezultatai koreliuoja su EC ir pH matavimų rezultatais (3.7 pav.) ir rodo, kad MWCNTs PC tešloje sumažina EC trukdo jonams prasiskverbti ị tirpalą ir sumažina $\mathrm{pH}$. Dèl žemesnio $\mathrm{pH}$ cemento mineralų tirpimo procesas vyksta léčiau, o tai rodo EXO reakcijos temperatūros pokyčiai.

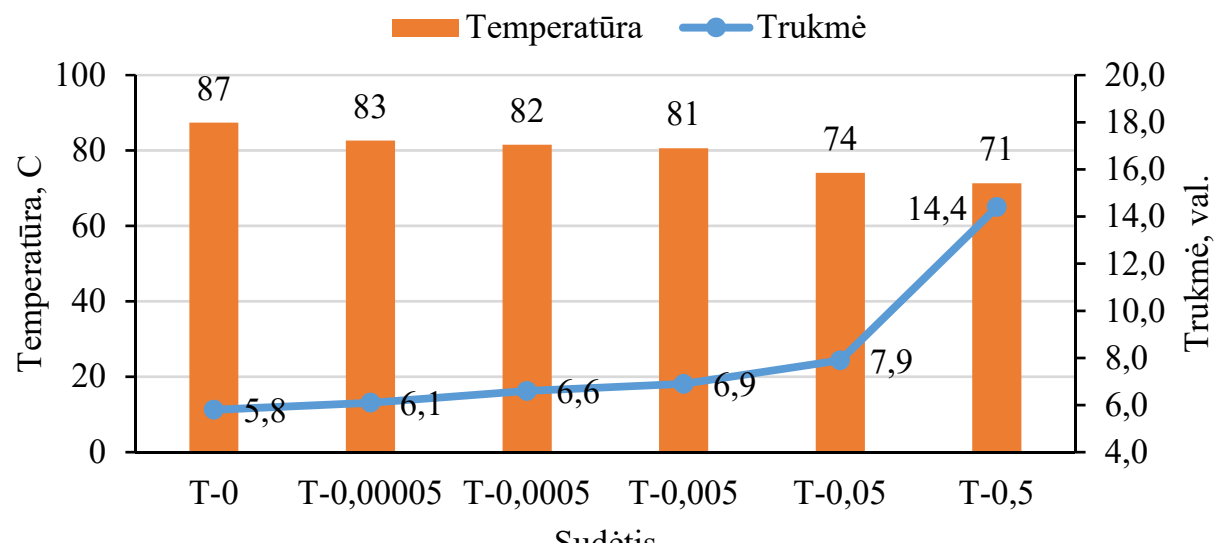

3.7 pav. Daugiasienių anglies nano vamzdelių kiekio poveikis egzotermijos temperatūros kitimui

Fig. 3.7. Exothermic reaction temperatures depending on the amount of multi-walled carbon nano tubes 
Taip pat nustatyta, kad padidejęs MWCNTs kiekis PC tešloje prailgina maksimalios EXO temperatūros pasiekimo laiką nuo 6,1 iki 14,4 val. Maksimali EXO temperatūra T-0 bandinyje buvo pasiekta po 5,8 val., o bandiniuose su $0,00005-$ $0,05 \%$ MWCNTs kiekiais tai ivyko 6,1-7,9 val. intervale.

Didžiausias MWCNTs kiekis $(0,5 \%)$ prailgino maksimalios EXO temperatūros pasiekimo laiką daugiau nei 500 min. (beveik du kartus), palyginus su kontroliniu bandiniu. Taip pat galimas karboksimetilceliuliozès cemento hidratacijos lètinimas, kaip nurodè Karpova (2020).

MWCNTs lètino pradinę cemento hidrataciją 24 val. laikotarpiu. Tyrimų rezultatai parodè, kad MWCNTs šviežiose cemento tešlose labai sumažino jų elektrinị laidumą (iki 17 \%), pH (iki 6,8 \%), dinaminę klampą (iki 3 kartų) ir prailgino rišimosi laiką (iki 2,2 karto), o tai kartu pailgino maksimalios EXO temperatūros pasiekimo laiką (iki 2,2 karto) ir sumažino hidratacijos temperatūrą.

\subsubsection{Cemento tešlos struktūros formavimasis}

UIG pokyčiai parodo ịtaką struktūros formavimuisi bandiniuose kietejjimo metu (3.8 pav.). Po 2 paru kietejjimo kontrolinio bandinio T-0 UIG reikšmė pasiekė $3820 \mathrm{~m} / \mathrm{s}$ vertę. MWCNTs kiekio padidèjimas sudètyje iki 0,005\% palaipsniui didino bandinių UIG iki $3860 \mathrm{~m} / \mathrm{s}$. Bandinių su didesniu MWCNTs kiekiu $(0,05 \%$ ir $0,5 \%)$ UIG pasiekè mažesnes $3835-3840 \mathrm{~m} / \mathrm{s}$ vertes.

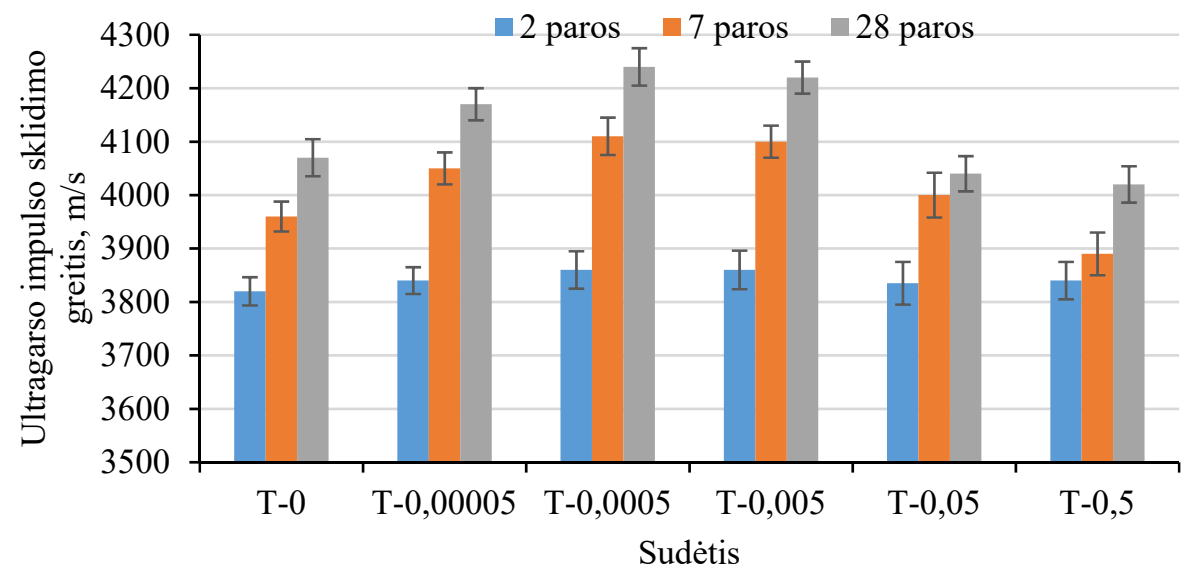

3.8 pav. Daugiasienių anglies nano vamzdelių kiekio poveikis cemento akmens bandinių ultragarso impulso sklidimo greičio vertems

Fig. 3.8. Ultrasound pulse velocity of cement stone samples depending on the amount of multi-walled carbon nano tubes 
Bandiniuose su mažesniais MWCNTs kiekiais $(0,00005 \%, 0,0005 \%$, $0,005 \%$ ) po 7 parų kietejjimo pastebètas ženklus UIG padidejjimas (UIG vertè padidejo $4050-4110 \mathrm{~m} / \mathrm{s}$ ). Šiuos rezultatus galima paaiškinti tuo, kad MWCNTs užpildè poras tarp PC hidratacijos produktų (Siddique \& Mehta, 2014). Bandiniuose su didesniais MWCNTs kiekiais UIG vertès pasiekè 4000 ir $3890 \mathrm{~m} / \mathrm{s}$.

Ilgesnis kietejjimo laikas (28 paros) toliau skatina bandinių struktūros pokyčius. Bandinių su mažiausiu MWCNTs kiekiu UIG vertès siekė $4170 \mathrm{~m} / \mathrm{s}$, $4240 \mathrm{~m} / \mathrm{s}$ ir $4220 \mathrm{~m} / \mathrm{s}$, o tai yra 2,5\%, 4,2\% ir 3,7\% daugiau, palyginti su kontroliniu bandiniu. Bandinių su didesniais $(0,05 \%, 0,5 \%)$ MWCNTs kiekiais UIG vertès kito nedaug ir buvo mažesnès nei kontrolinio bandinio.

\subsubsection{Daugiasienių anglies nano vamzdelių poveikis cemento akmens gniuždymo stipriui}

Kontrolinio T-0 bandinio gniuždymo stipris po 2 paru kietejjimo pasiekè $61 \mathrm{MPa}$ vertę. Padidinus MWCNTs kiekį PC akmenyje iki 0,005 \%, bandinių stipris padidejo 7,3 \% (3.9 pav.). Tą pačią tendenciją savo tyrimuose nurodè kiti mokslininkai (Abu Al-Rub et al., 2012; Laukaitis et al., 2012; Makar \& Chan, 2009; Wang et al., 2013; Xu et al., 2015; Yakovlev et al., 2006).

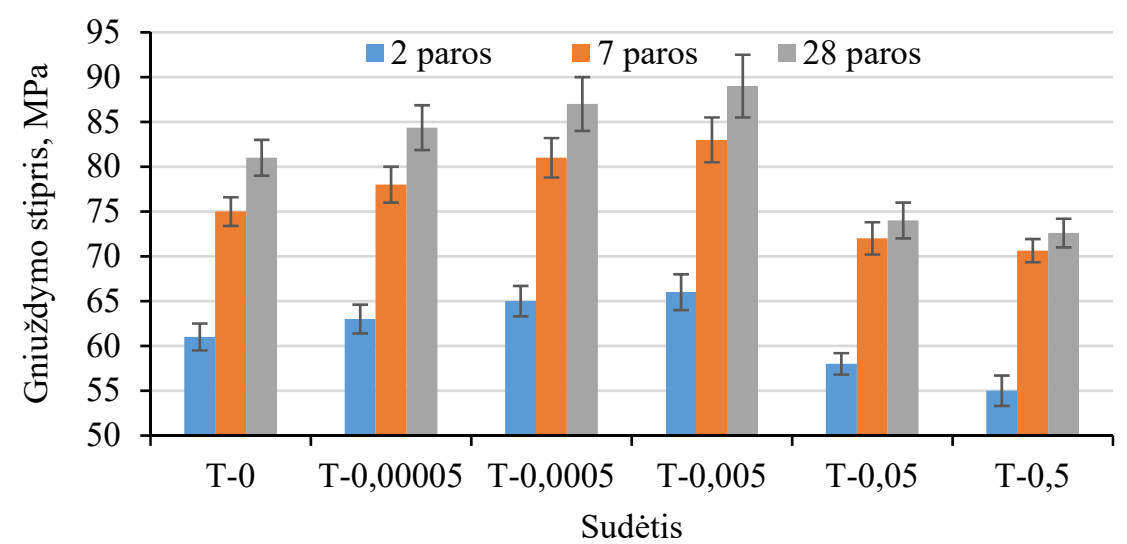

3.9 pav. Daugiasienių anglies nano vamzdelių kiekio poveikis sukietejjusių cemento akmens bandiniu gniuždymo stipriui

Fig. 3.9. Compressive strength of cement stone samples, depending on the amount of multiwalled carbon nano tubes 
Bandinių su $0,05 \%$ ir $0,5 \%$ MWCNTs gniuždymo stipris sumažėja $5 \%$ ir $10 \%$ lyginant su kontroliniu. Tos pačios tendencijos buvo stebimos ir po 7 parų kietejimo. 0,00005-0,005\% MWCNTs kiekis bandiniuose, palyginus su kontrolinio bandinio stipriu (75 $\mathrm{MPa})$, padidina gniuždymo stiprị iki 9,3\%, tačiau dar didesnis MWCNTs kiekis $(0,05 \%$ ir $0,5 \%)$ sumažina gniuždymo stiprị $4 \%$ ir $6,7 \%$. Po 28 parų kietejjimo kontrolinio bandinio gniuždymo stipris padidejja 6,5\%, o bandinių su 0,00005-0,005\% MWCNTs kiekiais iki 7,4\%. Didesni MWCNTs kiekiai (0,05\% ir 0,5\%) sumažina gniuždymo stiprị 8,7 \% ir 9,8\%. Šie rezultatai rodo, kad 2-28 parų kietẻjimo laikotarpiu mažesni MWCNTs kiekiai (iki $0,005 \%$ ) gniuždymo stiprị padidina 7-9 \%, o didesni MWCNTs kiekiai stiprị sumažina 7-10\%. Tos pačios tendencijos PC akmeniui su mažesniais MWCNTs kiekiais $(0,025,0,05$ ir $0,1 \%$ nuo PC kiekio) buvo stebimos kituose tyrimuose (Xu et al., 2015). I bandinius pridèjus $0,025 \%, 0,05 \%$ ir $0,1 \%$ MWCNTs, gniuždymo stipris po 7 parų atitinkamai padidejo $9,4 \%, 18,32 \%$ ir $21,78 \%$, o po 28 paru $-6,25 \%, 12,73 \%$ ir $14,62 \%$. Kiti autoriai (Hu et al., 2014; Musso et al., 2009) nustate, kad dar didesnis MWCNTs kiekis $(0,3-1 \%$ nuo PC kiekio) sumažino gniuždymo stipri po 28 parų kietẻjimo nuo $7 \%$ iki $13,18 \%$.

Didesnius MWCNTs kiekius (iki $1 \%$ nuo PC kiekio) tyrinèję mokslininkai (Konsta-Gdoutos, 2010; Wang et al., 2013; Siddique \& Mehta, 2014) nurode, kad, tiriant bandinių su didesniu MWCNTs kiekiu SEM nuotraukas, jų struktūroje buvo rasti mikroịtrūkiai ir dèl to mažèja bandinių gniuždymo stipris. Taip pat pastebèta, kad aplink PC grūdelius aglomeravosi MWCNTs. Šie aglomeratai lèmé tik dalinę PC grūdelių hidrataciją ir silpnus hidratacijos metu susidariusių junginiu ryšius. Mūsų tyrimais nustatyta, kad bandinyje MWCNTs kiekiui viršijus 0,005 \%, gniuždymo stiprio vertè mažèja. Matyti, kad mūsų tyrimai taip pat patvirtina minètų tyrèjų nuomonę.

\subsubsection{Daugiasienių anglies nano vamzdelių poveikis cemento akmens lenkimo stipriui}

Panašias tendencijas dèl gautu gniuždymo stiprio verčių rodo ir PC akmens lenkimo stiprio bandymų rezultatai. Po 2 parų kietejjimo bandinių, turinčių mažesnị MWCNTs kiekị (iki 0,005 \%), lenkimo stipris padidejo iki 33,3 \%, o bandinių su didesniu MWCNTs kiekiu (iki 0,5\%), palyginus su kontroliniu bandiniu, sumažejo 3,4 \% ir 13,3 \% (3.10 pav.). Po 7 paru kietejjimo kontrolinio bandinio ir bandinių, turinčių mažesnị MWCNTs kiekị, lenkimo stiprio skirtumas siekè 19,5\%, o bandinių, turinčių didesnị MWCNTs kiekị, lenkimo stipris buvo $1,5 \%$ ir $9 \%$ mažesnis už kontrolinio bandinio. Po 28 paru kietėjimo bandinių, turinčių mažesnị MWCNTs kiekị, skirtumas sudarè 17,8 \%, bandinių, 
kurių MWCNTs kiekis buvo didesnis, lenkimo stipris buvo 2,8 \% ir 8,3 \% mažesnis nei kontrolinio bandinio.

Kituose tyrimuose su mažesniais MWCNTs kiekiais $(0,025-0,1 \%)$ (KonstaGdoutos et al., 2010a, 2010b; Zou et al., 2015) ir didesniais MWCNTs kiekiais ( $1 \%$ ) lenkimo stiprio rezultatų tendencijos buvo tokios pačios (Hu et al., 2014). Kitų tyrejjų nustatytas optimalus MWCNTs kiekis bandinyje yra 0,08 \% (Wang et al., 2013).

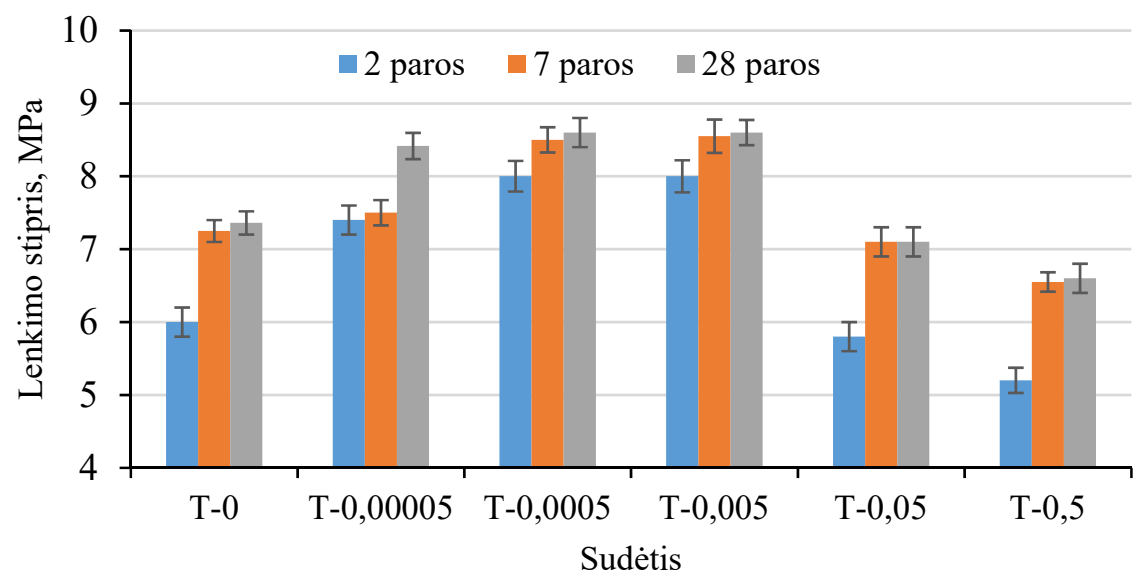

3.10 pav. Daugiasienių anglies nano vamzdelių kiekio poveikis cemento akmens bandinių lenkimo stipriui

Fig. 3.10. Flexural strength of cement stone samples, depending on the amount of multi-walled carbon nano tubes

Mūsų tyrimo rezultatai rodo, kad lenkimo stiprio pokyčių tendencijos atitinka gniuždymo stiprio pokyčius, tačiau lenkimo stiprio padidèjimas / sumažèjimas procentine išraiška buvo didesnis nei gniuždymo.

\subsubsection{Daugiasienių anglies nano vamzdelių poveikis cemento akmens vandens sugerčiai}

Bandinių vandens sugerties kinetikos analizė (3.11 pav.) parodè, kad 2 paras kietèjusiuose bandiniuose su MWCNTs kiekiais iki 0,005\%, palyginus su kontroliniu, vandens sugerties vertès po 30, 60, 90 min. ir 24 h sumažèjo taip: 1,2-10,9\%, $0,6-7,4 \%, 0,6-7,5 \%$ ir $1,1-9,1 \%$. Bandiniuose su $0,5 \%$ MWCNTs vandens sugerties vertes padidejo $0,6 \%, 6,0 \%, 7,7 \%$ ir $8,7 \%$. 


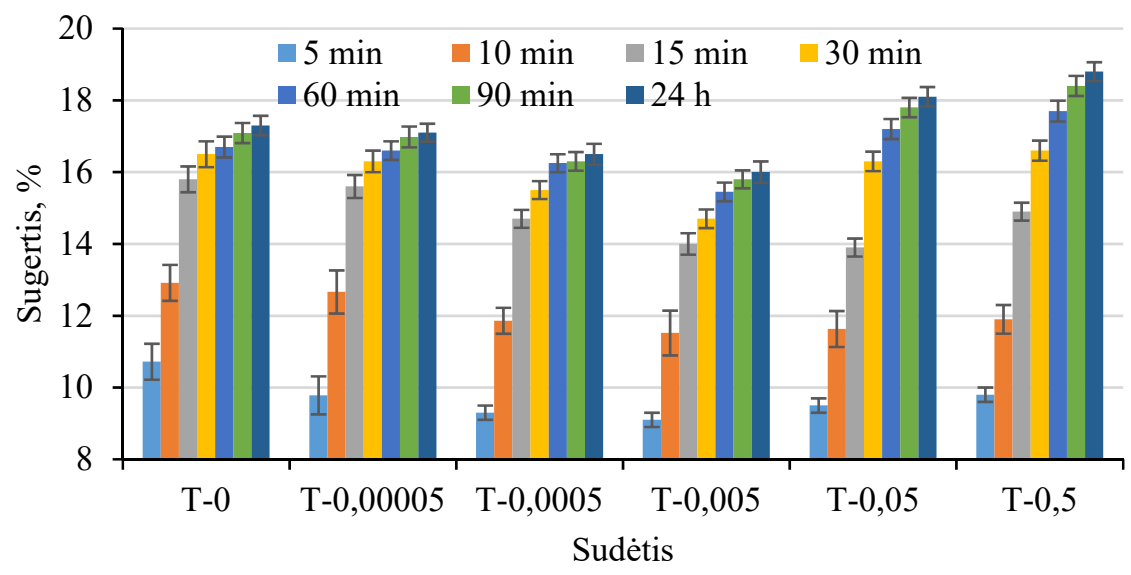

3.11 pav. Daugiasienių anglies nano vamzdelių kiekio poveikis 2 paras kietejjusių bandinių vandens sugerties vertems

Fig. 3.11. Water absorption of 2 days hardened samples, depending on the amount of multi-walled carbon nano tubes

28 paras kietejusiuose bandiniuose vandens sugerties kitimo tendencija buvo panaši (3.12 pav.). MWCNTs kiekis $0,00005-0,005 \%$ po 30, 60, 90 min. ir $24 \mathrm{~h}$ mažina vandens sugerties vertes taip: $1,35-6,8 \%, 3,2-9,7 \%, 2,5-9,6 \%$ ir $2,5-$ $10 \%$, lyginant su kontroliniu bandiniu. 0,5\% MWCNTs kiekis bandiniuose, lyginant su kontroliniu bandiniu, didina vandens sugerti $2,7 \%, 10,9 \%, 11,5 \%$ ir $10,6 \%$.

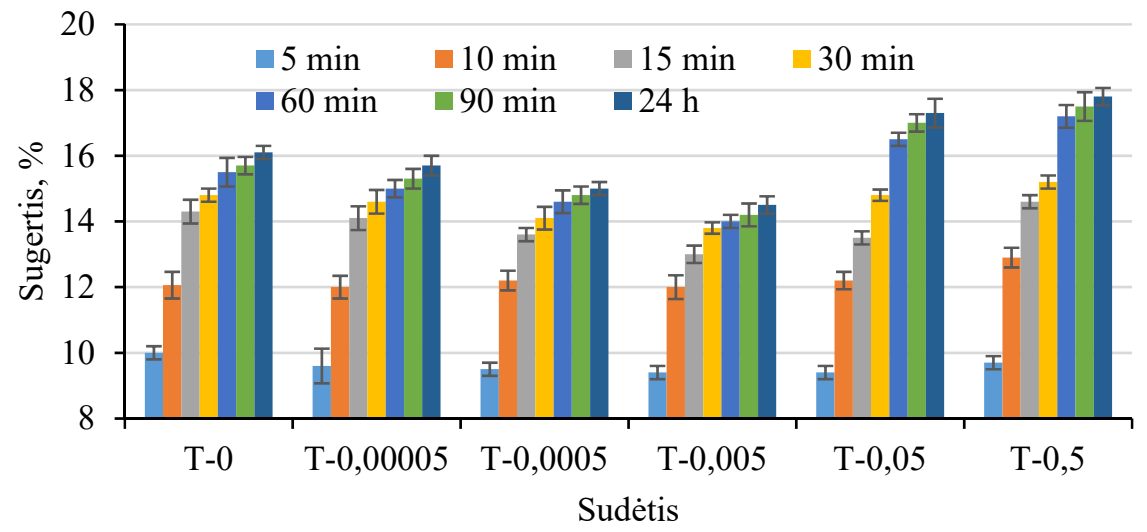

3.12 pav. Daugiasienių anglies nano vamzdelių kiekio poveikis 28 paras kietejusių bandinių vandens sugerties vertèms

Fig. 3.12. Water absorption of 28 days hardened samples, depending on the amount of multi-walled carbon nano tubes 
Vandens sugerties tyrimų su mažesniais MWCNTs kiekiais (iki 0,005 \%) bandiniuose rezultatus patvirtina kiti tyrejjai (Siddique \& Mehta, 2014), teigę, kad MWCNTs sumažino bendrą porų tūị ir veikè kaip tuštumų užpildas, todèl, pridèjus $0,015-0,045 \%$ MWCNTs, vandens sugertis sumažèja. Kiti tyrèjai yra atlikę bandymus su dar didesniais MWCNTs kiekiais $(0,5 \%, 1 \%$ ir 1,5\%) (Kordkheili et al., 2012). Bandymai parodè, kad vandens sugertis mažèjo. Tačiau mūsų atveju didesnis MWCNTs kiekis $(0,05 \%$ ir $0,5 \%)$ sukuria labiau poretas struktūras ir tai patvirtina UIG tyrimų rezultatai (3.8 pav.).

\subsection{Skirtingo tipo cheminiụ ịmaišų poveikis cemento hidratacijai ir savybèms}

\subsubsection{Cheminiụ įmaišų tirpalụ pH ir elektrinis laidumas}

Siekiant geriau įvertinti SP (A), SP (B) ir SP (C) tirpalų savybes, buvo atlikti EC ir $\mathrm{pH}$ matavimai. Išmatuoti $\mathrm{SP} \mathrm{pH}$ ir EC tyrimų rezultatai pateikti 3.2 lenteleje. Išanalizavus lentelès duomenis nustatyta, kad SP (B) turi šarminį, SP (A) - silpnai rūgštinị, o SP $(C)$ - rūgštinị $\mathrm{pH}$. Panašios $\mathrm{SP}$ pH vertès nustatytos ir kitame tyrime (Pundienė et al., 2016). Yra žinoma, kad EC priklauso nuo jonų kiekio tirpale. SP (A) turi labai didelę EC vertę, kuri buvo 3,9 karto didesnè už SP (C) ir 2,5 karto didesnè už SP (B). Panašios SP pH vertès nustatytos ir kitame tyrime (Pundienė et al., 2016).

3.2 lentelė. Laboratorijoje išmatuotų plastifikuojančių betono įmaišų pH ir elektrinio laidumo vertès

Table 3.2. Electrical conductivity and $\mathrm{pH}$ values of plasticizers obtained in the laboratory

\begin{tabular}{|l|c|c|c|}
\hline \multirow{2}{*}{} & \multicolumn{3}{|c|}{ Plastifikuojančios betono įmaišos žymèjimas } \\
\cline { 2 - 4 } & $\mathrm{SP}(\mathrm{A})$ & $\mathrm{SP}(\mathrm{B})$ & $\mathrm{SP}(\mathrm{C})$ \\
\hline $\mathrm{pH}$ & 6,87 & 8,10 & 4,75 \\
\hline $\mathrm{EC}, \mathrm{mS}$ & 10,10 & 3,86 & 2,51 \\
\hline
\end{tabular}

Paruošti skirtingų koncentracijų vandeniniai SP tirpalai (3.13 pav. a) rodo panašias tendencijas, kaip ir nustatytos SP savybès, pateiktos 3.2 lentelèje. 


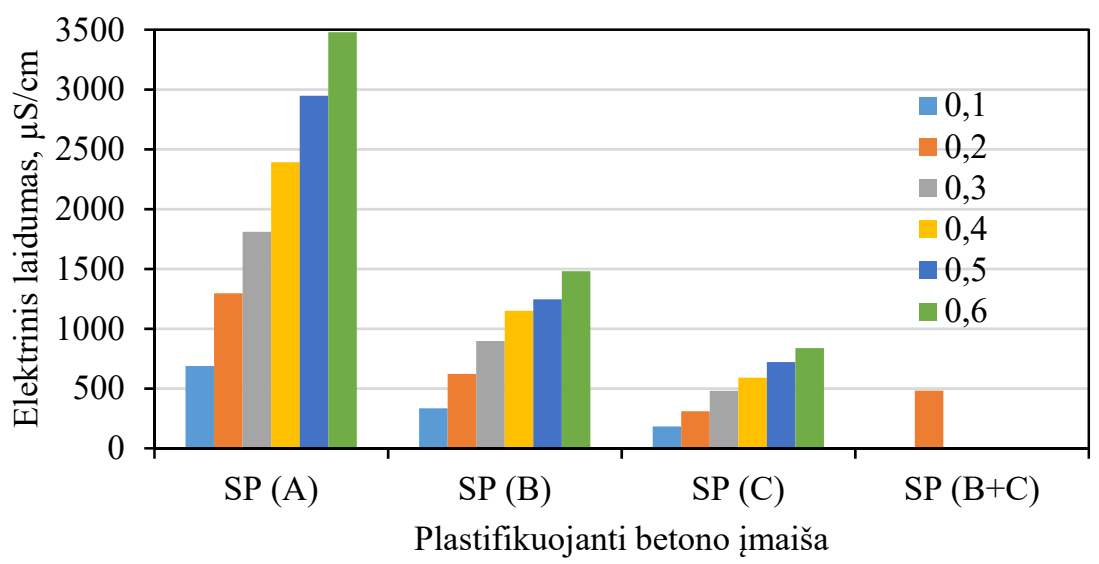

3.13 pav. Skirtingų koncentracijų plastifikuojančių betono įmaišų vandeninių tirpalų elektrinio laidumo vertès

Fig. 3.13. Electrical conductivity values of water solutions with different amounts of plasticizers

Tyrimams buvo paruošti skirtingų koncentracijų SP tirpalai ir vienas tirpalas su dviejų SP mišiniu, planuojamu naudoti tolesniuose tyrimuose. Nustatyta, kad didžiausios EC vertès buvo užfiksuotos SP (A), o žemiausios - SP (C) vandens tirpaluose.

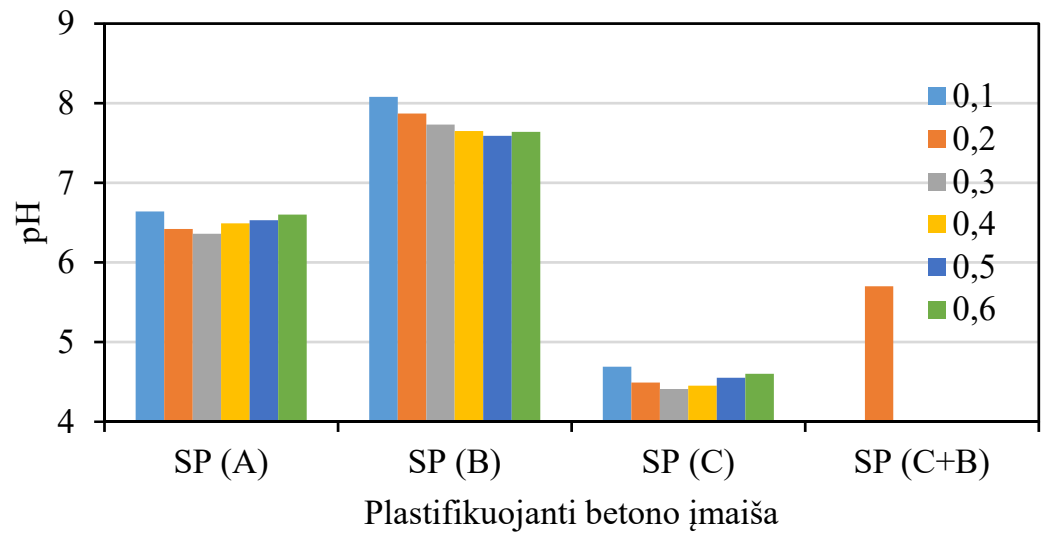

3.14 pav. Skirtingų koncentracijų plastifikuojančių betono įmaišų vandeninių tirpalų $\mathrm{pH}$ vertès

Fig. 3.14. $\mathrm{pH}$ values of water solutions with different amounts of plasticizers 
Manoma, kad SP (A) turi aukštą EC dèl didžiausio R-SO ${ }^{-3}$ grupių skaičiaus (Burgos-Montes et al., 2012). Remiantis tyrejų duomenimis, SP (B) ir SP (C) EC labiausiai priklauso nuo karboksilo grupiu $\mathrm{COO}^{-}$skaičiaus ir skirtingos SP (C) atveju polimero architektūros (Plank \& Hirsch, 2007), kuriai būdinga didesnè molekulinè masè, mažesnis šoninių grandinių tankis, trumpesnès šoninès grandinės ir mažesnès EC vertès. SP (B) būdinga mažesnè molekulinè masè, ilgesnès šoninès grandinès ir aukštesnès EC vertès. Dviejų SP mišinio (SP (B) $(0,1 \%)$ ir SP (C) $(0,1 \%)$ vandeninio tirpalo EC vertès praktiškai atspindi abiejų SP EC verčių sumą, o $\mathrm{pH}$ vertė siekia 5,70.

Visų trijų SP vandens tirpalų $\mathrm{pH}$ vertè išlieka gana stabili, nepriklausomai nuo SP koncentracijos (3.14 pav.).

\subsubsection{Cheminiụ ịmaišụ poveikis cemento tešlos sklidumui}

Siekiant PC matricai parinkti tinkamiausią SP tipą, buvo atlikti sklidumo tyrimai. Iš karto po PC tešlų sumaišymo atlikti tyrimai rodo, kad su mažiausiu $(0,1 \%) \mathrm{SP}$ kiekiu didžiausios sklidumo vertès pasiektos SP (A) ir SP (C) bandiniuose (3.15 pav.).

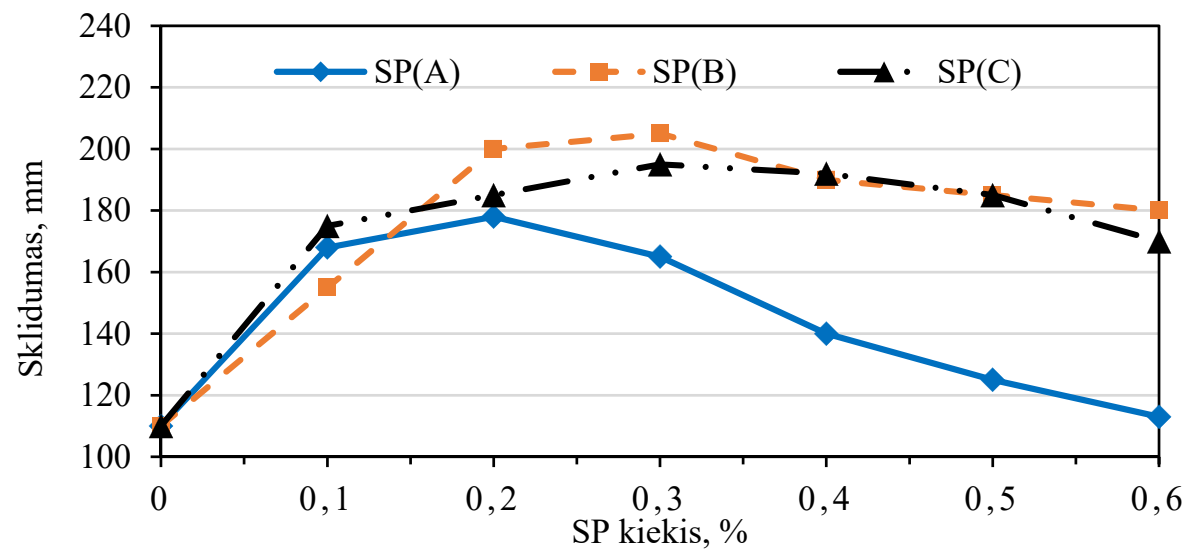

3.15 pav. Plastifikuojančių betono įmaišų kiekio ir tipo poveikis cemento tešlos sklidumui

Fig. 3.15. Cement paste spread area, depending on the amount and type of plasticizers

$0,2 \%$ ir $0,3 \%$ SP koncentracijos bandinių didžiausias sklidumo vertes pasiekè SP (B) ir SP (C), o SP (A) sklidumas mažeja. Toliau didinant SP koncentraciją iki $(0,4 \%$ ir $0,5 \%)$, pastebètos tendencijos išlieka. Maksimalaus SP kiekio (iki 0,6 \%) PC tešloje tyrimai parodè, kad bandinių su SP (B) ir SP (C) sklidumas šiek tiek sumažejo, o bandinio su SP (A) sklidumas - ženkliai. Šie rezultatai rodo, kad PC tešloje esant nedideliam SP kiekiui, sudètinga įvertinti, kuris SP tipas yra 
geriausias, nes sklidumo vertès skiriasi mažai. Žemos SP (A) sklidumo vertès gali būti paaiškintos tuo, kad tiek SP (A) sulfonatu grupès, tiek sulfatų jonai, esantys PC tešloje, kaip nurodo autoriai (Mikanovic \& Jolicoeur, 2008), gali reaguoti su $\left(\mathrm{C}_{3} \mathrm{~A}+\mathrm{C}_{4} \mathrm{AF}\right)$ fazėmis ir sudaryti etringitą arba analogiškus hidratacijos produktus. Šių reakcijų metu susidaro dideli adatų pavidalo etringito kristalai, kurie mažina PC tešlos sklidumą.

\subsubsection{Cheminių įmaišų poveikis cemento tešlos dinaminei klampai ir temperatūrai}

Siekiant papildyti sklidumo bandymus, buvo atlikti PC tešlų su tais pačiais SP kiekiais klampos ir temperatūros pokyčių matavimai 30 min. laikotarpiu (sudètys pateiktos 2.7 lenteleje). Palyginus kontrolinio bandinio K-0 klampą, pastebèta, kad bandinyje (3.16 pav.) su 0,2 \% SP(A) (vandens tirpalo EC verte $1295 \mu \mathrm{S} / \mathrm{cm}$ ) klampa mažejja tik trumpuoju laikotarpiu iki 5 min.

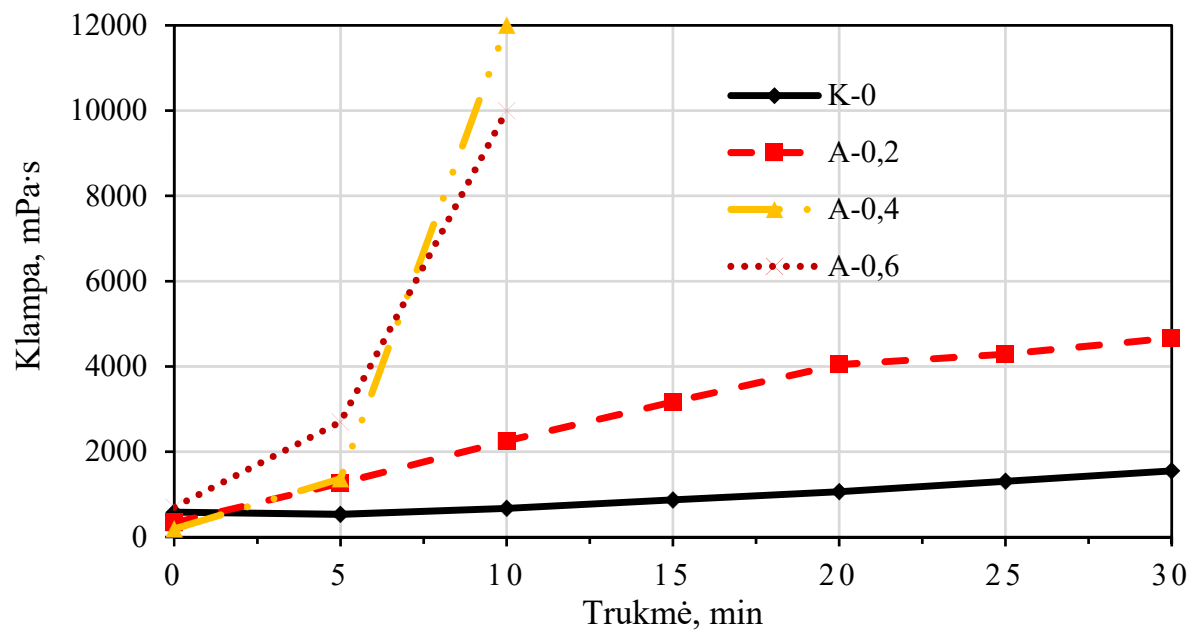

3.16 pav. Plastifikuojančios betono įmaišos (A) kiekio poveikis cemento tešlų klampai Fig. 3.16. Cement paste viscosity depending on plasticizer (A)

SP (A) kiekio didinimas PC tešloje nuo 0,4 \% iki 0,6 \% (vandens tirpalo EC padidejo nuo 2392 iki $3478 \mu \mathrm{S} / \mathrm{cm}$ ) iš karto padidino klampą, o maksimali klampos verte (12 $000 \mathrm{MPa} \cdot \mathrm{s})$ buvo pasiekta po 5-10 min. Matome, kad didesnis SP (A) kiekis blogina PC tešlos reologines savybes. Tai sutampa su kitų straipsnių apžvalgomis (Bishop \& Barron, 2006; Sakai et al., 2003), kuriuose rašoma, kad padidejus sulfato jonų koncentracijai, PC tešlos sklidumas mažèja. SP (A) paspartina etringito susidarymą, todèl ir sumažejja PC tešlos sklidumas. 
Užfiksuoti temperatūros pokyčiai PC tešlose (3.18 pav.) koreliuoja su klampos tyrimų rezultatais. Kuo didesnis SP (A) kiekis PC tešloje, tuo žemesnè tešlos temperatūra. Tačiau po 5 min. pastebètas reikšmingas $4-6{ }^{\circ} \mathrm{C}$ temperatūros pakilimas tešloje su didesniu SP (A) kiekiu. Šis temperatūros šuolis tiesiogiai susijęs su etringito susidarymu ir didejjančia klampa. Literatūroje pažymèta (Bishop \& Barron, 2006), kad SP (A) sukelia greitą temperatūros pakilimą PC tešloje iš karto po sumaišymo. Autoriai nurodo, kad tai susiję su greita PC aliuminatinès fazès reakcija, dèl kurios pagreitēja etringito adatų struktūros susidarymas.

PC tešlų su SP (C) (joms būdingos mažos EC vertès vandens tirpale (3.17 pav.) klampa yra perpus mažesnè, palyginti su PC tešlomis, kuriose buvo naudotas SP (A) (3.16 pav.). Matome, kad sudètyse pakanka 0,2 \% kiekio šio SP (kurio EC vertè $310 \mu \mathrm{S} / \mathrm{cm}$ ) žemai klampai užtikrinti, nes didesni SP (C) kiekiai reikšmingo poveikio klampai neturi. Literatūroje teigiama (Kim et al., 2014), kad polikarboksilato pagrindu pagamintas SP, kuris gali turèti iki trijų kartų didesnę molekulinę masę ir ilgesnę šoninę grandinę, palyginti su poliakrilato pagrindu pagamintais SP, ilgą laiką gali užtikrinti mažas klampos vertes. Svarbu pažymėti, kad polikarboksilatai daugiausia sulètina mineralo alito tirpimą (Plank et al., 2012, 2009; Tian et al., 2019). Ši poveiki gali paaiškinti rūgštinis šio SP pH.

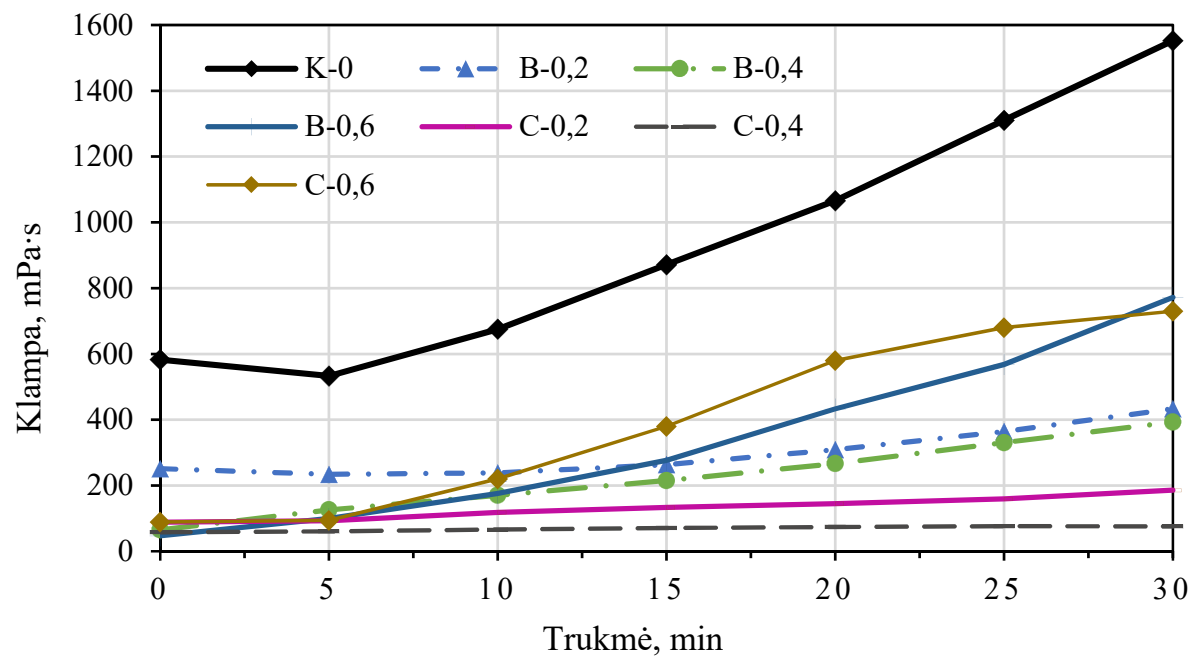

3.17 pav. Plastifikuojančių betono įmaišų (B) ir (C) kiekio poveikis cemento tešlu klampai

Fig. 3.17. Cement paste viscosity depending on plasticizers (B) and (C)

Visos tešlos su SP(C), palyginus su kontroline be SP, matavimo pradžioje turejo žemesnes temperatūras (3.18 pav.). Tačiau tešlų, turinčių $0,2 \%$ ir $0,4 \%$ SP (C), temperatūra buvo labai panaši, o žemiausia pastebèta tešloje su 0,6 \% 
SP (C). Pažymėtina, kad tik tešloje su 0,6\% SP (C) pastebètas temperatūros pakilimas per pirmąsias $5 \mathrm{~min}$. Šis temperatūros pakilimas atsispindi tešlų klampos kreivese, kuriose klampa staigiai padideja. Šie rezultatai patvirtina, kad didesnis SP (C) kiekis ir atitinkamai didesnis jonų kiekis (vandens tirpalo EC pasiekia 838 $\mu \mathrm{S} / \mathrm{cm}$ ) sukelia aktyvesnę reakciją su $\mathrm{C}_{3} \mathrm{~A}$, tada susidaro etringitas ir atitinkamai auga klampa.

PC tešlų su SP (B) (3.17 pav.) klampos vertès yra šiek tiek didesnès nei tešlose su SP (C), tačiau pokyčiai yra labai panašūs. Nepaisant to, tešlose su SP (B) temperatūros svyravimai (3.18 pav.) yra skirtingi ir panašesni ị rezultatus, gautus bandant tešlas su SP (A). SP (B) kiekis $(0,2 \%)$ pradinę tešlos temperatūrą mažina, o didesnis kiekis $(0,4-0,6 \%)$ jau pradeda didinti. Kuo didesnis SP (B) kiekis PC tešloje, tuo aukštesnè tešlos temperatūra. Galimai dèl didesnès SP (B) EC vertès iki $1480 \mu \mathrm{S} / \mathrm{cm}$, kai SP (B) kiekis vandens tirpale yra 0,6\% ir atitinkamai didesnès jonų koncentracijos, $\mathrm{PC}$ tešlos temperatūra yra aukštesnè nei $\mathrm{PC}$ tešloje su tokiu pat 0,6 \% SP (C) kiekiu. Šis ryšys matomas klampos kitimo kreivèje. SP (B) sandarą sudarančios (Plank et al., 2009) trumpesnè pagrindinè grandinė ir ilgesnès šoninès grandinès, kurios yra atsakingos už jonų koncentraciją tirpale, PC tešloje daro šiek tiek trumpesni plastifikuojanti poveikį. Remiantis kitu tyrimu (Tian et al., 2019), didesnè joninių funkcinių grupių koncentracija vandeninèje fazėje pristabdo PC tešlos kietejjimą.

Išsami temperatūros pokyčių $\mathrm{PC}$ tešlose su skirtingais $\mathrm{SP}$ kiekiais analizė pateikta 3.19 paveiksle.

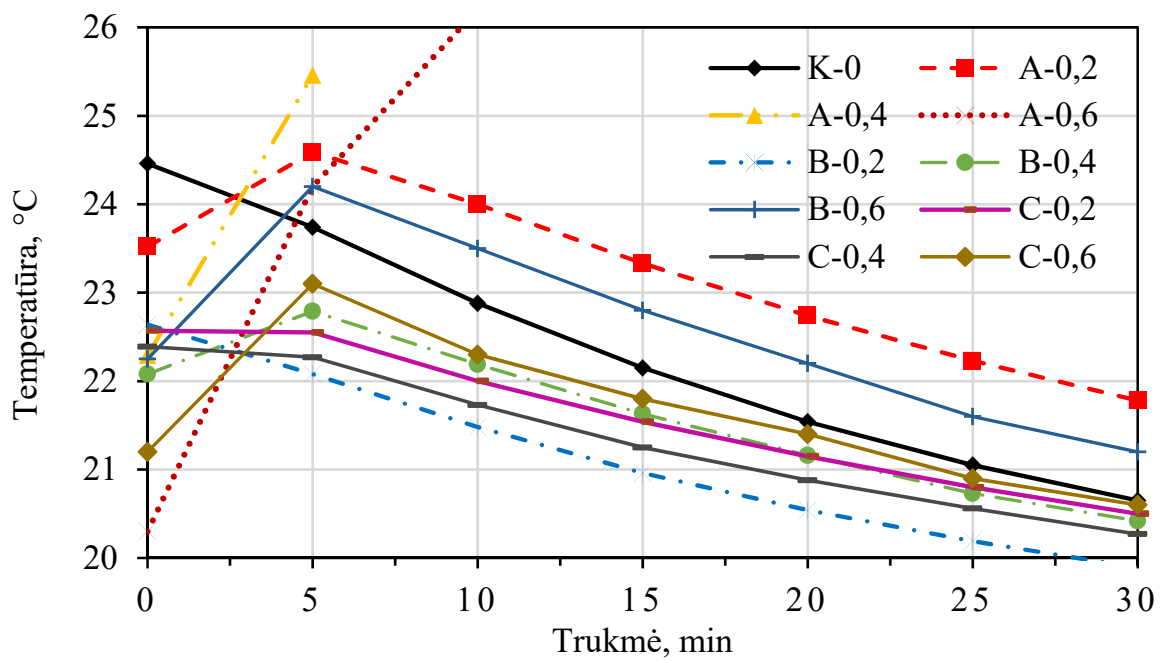

3.18 pav. Plastifikuojančių betono įmaišų kiekio ir tipo poveikis cemento tešlų temperatūrai

Fig. 3.18. Cement paste temperature depending on amount and type of plasticizers 


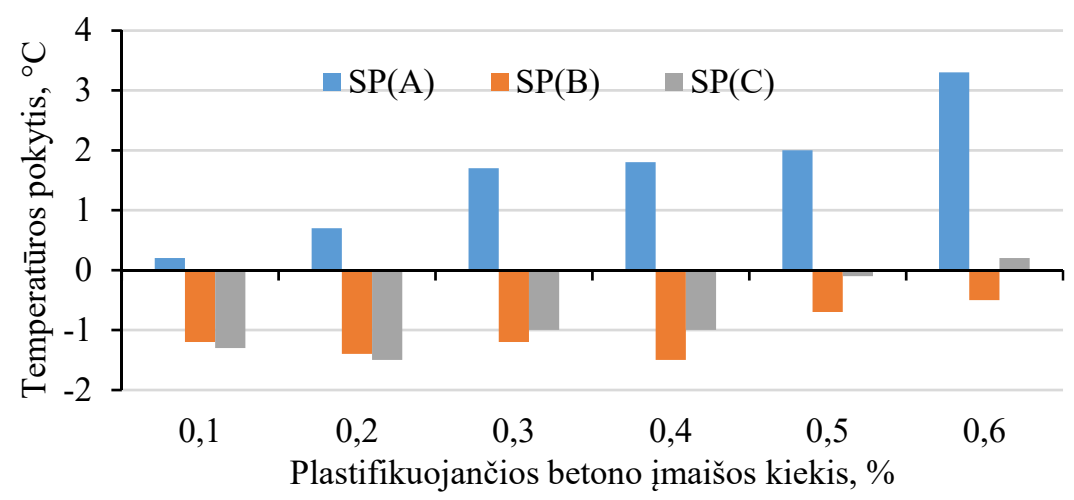

3.19 pav. Plastifikuojančių betono įmaišų kiekio ir tipo poveikis cemento tešlų temperatūros pokyčiams po 5 min.

Fig. 3.19. Cement paste temperature changes, depending on the amount and type of plasticizers after 5 minutes

Jame parodyti lyginamieji PC tešlos temperatūros pokyčiai po pirmujų 5 min., palyginti su kontroline PC tešla be SP. Aiškiai matyti, kad SP (A) labai skirtingai veikia PC tešlos temperatūrą, palyginus su SP (C) ir SP (B). Didinant SP (A) kiekị PC tešloje, jos temperatūra (taip pat jos klampa) nuosekliai didèja iki $3,3{ }^{\circ} \mathrm{C}$, palyginti su kontroline PC tešla, o SP (C) ir SP (B) veikia skirtingai, t. y. PC tešlos temperatūrą ir klampą abu SP mažina. Temperatūra PC tešlose su minètais SP maksimaliai sumažèja $1,5^{\circ} \mathrm{C}$.

Galima daryti išvadą, kad vien sklidumo tyrimų, atliktų iškart sumaišius PC tešlas, nepakanka objektyviam efektyviausio SP tipo įvertinimui. Atlikti PC tešlų klampos ir temperatūros pokyčių laike tyrimai ir duomenų analizè suteikia papildomų žinių apie skirtingų SP poveikị PC tešlų reologinėms savybėms.

\subsection{Cheminių ịmaišų ir daugiasienių anglies nano vamzdelių poveikis cemento akmeniui}

Norint pagerinti cemento akmens mechanines savybes, i cemento tešlą kartu su SP buvo idèta $0,005 \%$ (nuo cemento kiekio) MWCNTs (sudètys pateiktos 2.8 lenteleje). Šis kiekis pasirinktas remiantis 3.1 skyriaus tyrimais. MWCNTs tirpalo EC ir pH duomenys pateikti 3.1 lenteleje. Taip pat parinkta sudètis su SP mišiniu (S P(B) ir SP (C)). Šis SP mišinys buvo pasirinktas todèl, kad literatūroje (Plank et al., 2009) rasta duomenų apie efektyvų abiejų tipų SP mišinių su nanopriedais naudojimą. SP (B) ir SP (C) kiekis mišinyje buvo lygus, t. y. po $0,1 \%$. Bendras jų kiekis mišinyje sudaro $0,2 \%$. 
Cemento tešlų su MWCNTs ir SP charakteristikoms apibūdinti buvo atlikti EC, klampos, ultragarso impulsų greičio (UIG), EXO procesų tyrimai. Taip pat buvo atlikti jau sukietejusio cemento akmens DTA termografiniai ir mechaninių savybių tyrimai.

\subsubsection{Cemento tešlų konduktometrijos tyrimai}

Siekiant geriau įvertinti pasirinkto vienodo SP (A), SP (B) ir SP (C) kiekio $(0,2 \%)$, taip pat ir MWCNTs poveiki cemento tešlu EC pokyčiams, buvo atlikti cemento tešlų be MWCNTs ir su MWCNTs matavimai 40 min. laikotarpiu. Didelis ir greitas EC padidèjimas šiuo laikotarpiu apibūdina cemento mineralų tirpimo ir jonų perejimo ị tirpalą procesą.

Šiuo svarbiu laiko periodu SP ir nanopriedai daro didžiausią poveikị EC pokyčiams, nes vèlesniuose etapuose, susidarius kristalų hidratams, kai yra jonų pusiausvyra tirpale, EC vertès stabilizuojasi. Manoma, kad EC stabilizavimasis atspindi kristalų hidratų augimo pradžią (Burgos-Montes et al., 2012).

Kaip matyti 3.20 paveiksle, kontrolinès tešlos be SP EC vertès yra aukščiausios per visą matavimo laikotarpị. SP daro ịtaką cemento mineralų tirpimo procesui iškart po sumaišymo, fiksuojamas EC mažejimas. Vienodas SP kiekis skirtingai veikia cemento mineralų perèjimo ị tirpalą eigą. Aukščiausia PC tešlos EC vertè, t. y. 17,81 mS/cm, buvo nustatyta tešloje be SP. Cemento mineralų perèjimą i tirpalą mažiausiai stabdo SP (C), o labiausiai lètina SP (A). Tešloje su SP (A) EC vos siekia $15 \mathrm{mS} / \mathrm{cm}$. Tešlos su SP (B) EC verte pasiekia $16,6 \mathrm{mS} / \mathrm{cm}$, o tešloje su SP mišiniu - 16,3 mS/cm.

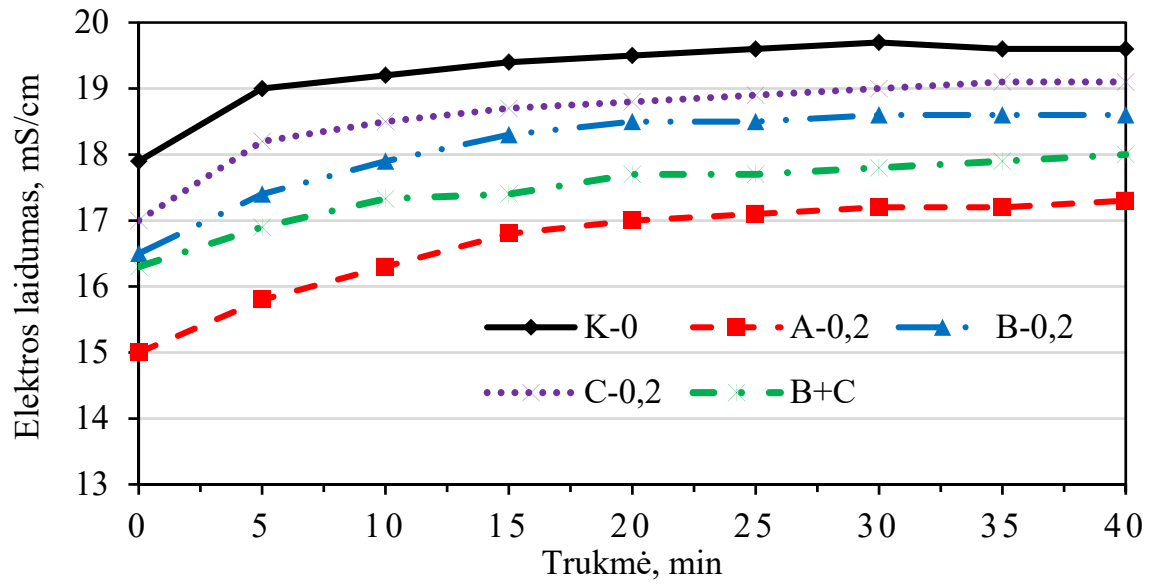

3.20 pav. Cemento tešlų su plastifikuojančiomis betono įmaišomis elektrinio laidumo pokyčiai

Fig. 3.20. Electrical conductivity changes of cement pastes with plasticizers and multi-walled carbon nano tubes 
Mažiausios EC vertès tešloje su SP (A) gali būti paaiškintos sulfonatų reakcija su $\mathrm{C}_{3} \mathrm{~A}$. Kai SP A) patenka ị cemento tešlą, sulfonatų jonai iškart reaguoja su aliuminatine faze taip prisijungdami prie etringito susidarymo, todèl EC vertès ir yra mažesnès. Taip pat yra žinoma, kad SP blokuoja cemento mineralų jonų perèjimą ị tirpalą.

EC tešlose labiausiai auga per pirmąsias 15-20 min., o vẻliau stabilizuojasi. Tešlose su SP (A) ir SP (B), kurių EC vertès vandens tirpaluose yra didesnès, būdingos panašios EC augimo kreivès.

Kaip matyti 3.21 paveiksle, MWCNTs, kuriems yra būdingos žemos EC vertès vandens tirpaluose, labai sulètina cemento mineralų jonų perèjimą ị tirpalą. Iš karto po sumaišymo visų tešlų su MWCNTs EC vertès yra kur kas mažesnès nei tešlose be MWCNTs. Palyginus su kontroline tešla K-0 (be SP), pasižyminčia aukščiausia EC verte, NK tešlos EC sumažeja 16,2 \% ir siekia $15 \mathrm{mS} / \mathrm{cm}$. Kitų tyrejuu rezultatai (Crachereau et al., 2001) rodo, kad karboksilmetilceliuliozé, kuri yra MWCNTs granulių rišiklis, yra silpna rūgštis, galinti sumažinti cemento mineralų jonų perèjimą i tirpalą. Karpovos (2020) atlikti cementinès tešlos su karboksilmetilceliuliozès priedu kalorimetriniai tyrimai patvirtina šią prielaidą. Tyrimais nustatyta, kad karboksilmetilceliuliozè smarkiai lètina cemento mineralu hidrataciją ir stabdo cemento mineralų jonų perējimą ị tirpalą. Taip pat tam gali turèti ịtakos MWCNTs sandara. MWCNTs vamzdeliai gali dengti cemento dalelių paviršių ir blokuoti cemento mineralų perejjimą ị tirpalą.

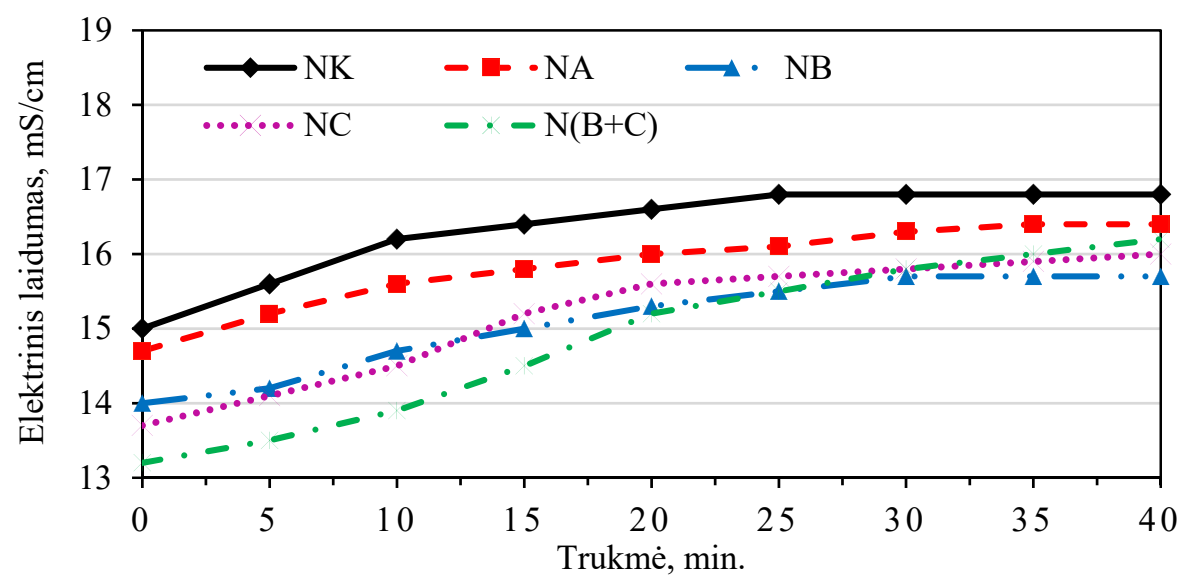

3.21 pav. Cemento tešlų su plastifikuojančiomis betono įmaišomis ir daugiasieniais anglies nano vamzdeliais elektrinio laidumo pokyčiai

Fig. 3.21. Electrical conductivity changes of cement pastes with plasticizers and multi-walled carbon nano tubes 
EC sumažèjimas tešlose NC ir NB (su SP (C) ir SP (B)), lyginant su tešlomis be MWCNTs, svyruoja $18-21,8 \%$ ir atitinkamai siekia $14,7 \mathrm{mS} / \mathrm{cm}$ bei $14 \mathrm{mS} / \mathrm{cm}$. Tešlos N (B+C) su SP mišiniu EC mažeja 23,5 \%, o jos EC pasiekia $13,7 \mathrm{mS} / \mathrm{cm}$. Tešlos NA EC mažeja $26,3 \%$ ir EC siekia 13,2 mS/cm. Matome, kad EC didejja šiek tiek vèliau, po 25-30 min., tačiau bendras EC pokyčiu pobūdis tešlose su MWCNTs išlieka panašus ị anksčiau aprašytą (3.20 pav.) SP poveikị PC tešlų EC vertèms.

\subsubsection{Cemento tešlų reologinių savybių tyrimai}

Buvo atlikti anksčiau minètų tešlų be ir su MWCNTs dinaminès klampos ir temperatūros pokyčio laikui einant matavimai. Ankstesniais tyrimais (Leonavičius et al.,2018) buvo nustatyta, kad, didinant MWCNTs kiekị tirpale (3.1 lentelè), tirpalo klampa didejja. Panašūs pastebejjimai pateikti Karpovos (2020) darbe, kuriame nustatyta, kad, didinant MWCNTs priedo kiekị cemento tešloje nuo 0 iki $0,24 \%$ (nuo cemento kiekio), tešlos plastinè klampa didèja.

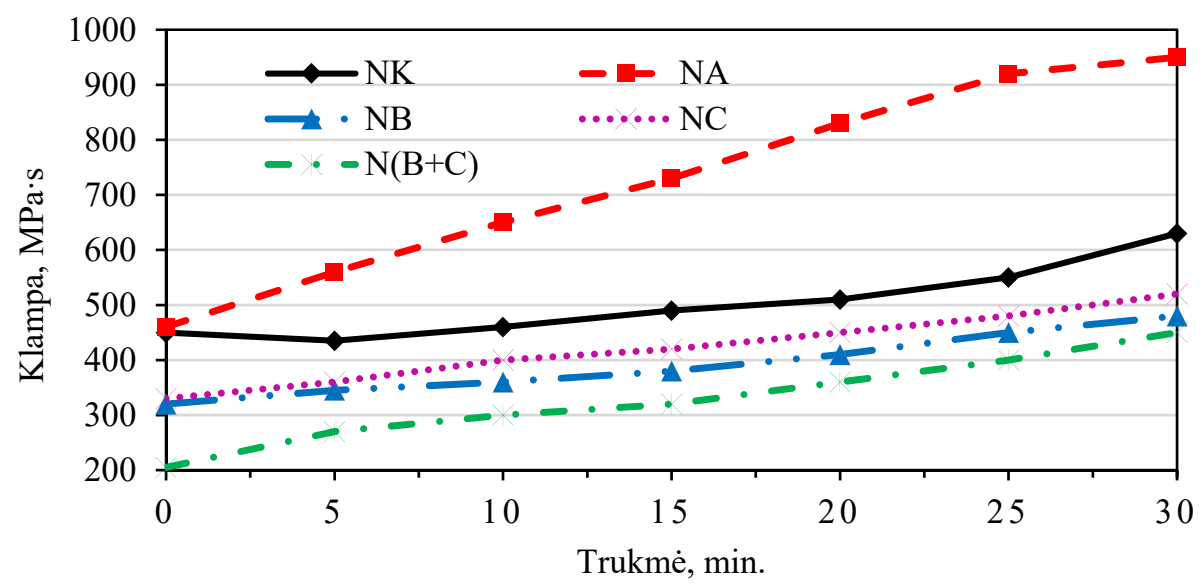

3.22 pav. Cemento tešlų su plastifikuojančiomis betono įmaišomis ir daugiasieniais anglies nano vamzdeliais klampos pokyčiai

Fig. 3.22. Cement pastes with plasticizers and multi-walled carbon nano tubes viscosity changes

Tačiau, palyginus gautus klampos tyrimų rezultatus (3.22 pav.) su tešlų be MWCNTs (3.16 ir 3.17 pav.) rezultatais, matyti, kad MWCNTs mažina pradinès klampos vertes tik kontrolinejje (NK) ir NA tešlose. Priešingai nei NK ir NA atveju, MWCNTs priedas didina NC ir NB tešlų pradinès klampos vertes iki 20$30 \%$. Tai gali būti dèl karboksimetilceliuliozès arba MWCNTs sandaros (nano- 
vamzdelių) poveikio. Tirpale esantys nanovamzdeliai, kurių gijų ilgis pagal duotus parametrus yra 100-10000 nm, pasklinda (Konsta-Gdoutos et al., 2010a) ant cemento dalelių paviršiaus. Apie ši reiškinị buvo aprašyta (Liebscher, Lange et al., 2017), kur nurodoma, kad nanovamzdeliu paviršiai gali prisitvirtinti prie cemento dalelių vandeniniame tirpale ir taip sumažinti vandens patekimą i cemento paviršių, kaip ir buvo pastebèta NK bandinio atveju.

Karboksimetilceliuliozès $0,29 \%$ (nuo cemento kiekio) poveikis cemento tešlai buvo tirtas Karpovos (2020) darbe. Tyrimai parodé, kad šios tešlos plastinè klampa buvo beveik perpus mažesnè nei cemento tešlos su 0,24 \% (nuo cemento kiekio) MWCNTs. Tai rodo, kad MWCNTs, palyginti su karboksimetilceliulioze, padidina cemento tešlos plastinę klampą.

Po 30 min. klampa reikšmingai padidejjo tik NA tešloje su SP (A) ir MWCNTs (3.22 pav.). Skirtumas tarp kontrolinio NK ir NA tešlu yra $320 \mathrm{MPa} \cdot s$. Naujai susidarę junginiai (etringitas ir kiti) sąveikauja su MWCNTs aglomeratais, kaip aprašyta Liebscher, Lange, et al. (2017), ir padidina klampą. Karpova (2020) tyrime taip pažymejjo, kad cemento tešlose su MWCNTs ir SP(A) plastinė klampa padideja, kai MWCNTs kiekis yra 0,24 \% (nuo cemento kiekio).

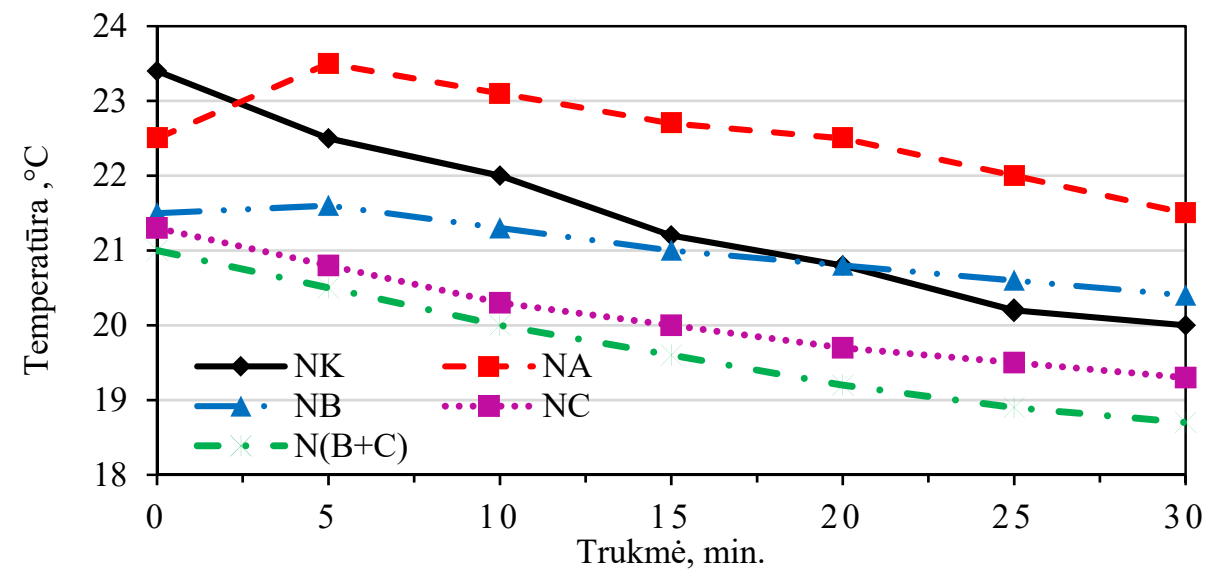

3.23 pav. Cemento tešlų su plastifikuojančiomis betono įmaišomis ir daugiasieniais anglies nano vamzdeliais temperatūros pokyčiai

Fig. 3.23. Cement pastes with plasticizers and multi-walled carbon nano tubes temperature changes

Palyginti su NK tešlos klampa, tešlose NC ir NB, kuriose SP (C) ir SP (B) sąveikauja su MWCNTs, tešlų klampa sumažeja apytiksliai $130 \mathrm{MPa} \cdot s$ ir tarp abiejų tešlu klampos verčių praktiškai nėra skirtumo. Palyginus su NK tešlos klampa, labiausiai dèl sąveikos su MWCNTs sumažejo N(B+C) tešlos klampa (maždaug perpus), kurioje buvo naudotas SP mišinys. Akivaizdu, kad abiejų SP 
derinys sąveikoje su MWCNTs užtikrina efektyvesnị sterinès stūmos efektą ir MWCNTs dispersiją. Tačiau Karpovos (2020) tyrimuose gauti priešingi rezultatai, rodantys, kad, didinant MWCNTs kieki cemento tešlose su SP(C) nuo 0 iki $0,12 \%$ (nuo cemento kiekio), tešlu plastinè klampa gerokai didejja.

Temperatūros matavimai paaiškina MWCNTs ir SP poveikị cemento hidratacijos procesams ir sklidumo rezultatus. Išbandytų tešlų temperatūros pokyčiai (3.23 pav.) rodo, kad iškart po sumaišymo visų bandinių tešlos temperatūra, palyginus su kontroliniu bandiniu NK, yra žemesnè. Tačiau po 5 min. NA tešlos su SP (A) temperatūra pakilo $2{ }^{\circ} \mathrm{C}$, NB tešlos su SP (B) nepakito, o likusių tešlų bandinių $(\mathrm{NC}, \mathrm{N}(\mathrm{B}+\mathrm{C}))$ temperatūra sumažèjo. Tolesni tyrimai parodè, kad temperatūra sumažèjo visose tešlose, tačiau NA tešlos su SP (A) temperatūra išliko $2{ }^{\circ} \mathrm{C}$ aukštesnè nei NK, o NB tešlos su SP(B) po 20-30 min. nuo sumaišymo pradžios buvo $0,3{ }^{\circ} \mathrm{C}$ aukštesnè nei $\mathrm{NK}$ tešlos bandinio.

\subsubsection{Cemento tešlų struktūros vystymasis}

Norint išsiaiškinti, kaip SP ir MWCNTs sąveika veikia cemento kietejjimo procesus ir struktūros susidarymą ankstyvuoju kietejimo laikotarpiu (per $24 \mathrm{~h}$ ), buvo atlikti PC tešlos su MWCNTs ir SP ultragarso impulso greičio (UIG) tyrimai (3.24 pav.). Daugelis mokslininkų (Cui et al., 2017; Reinhardt \& Grosse, 2004; Robeyst et al., 2008; Smith et al., 2002; Trtnik et al., 2008) nurode, kad ultragarsinio tyrimo metodas gali būti labai efektyvus stebint PC tešlos hidratacijos ir struktūros susidarymą. Hidratacijos eiga apibūdinama trimis etapais. 1-as - kai UIG tešlose nesikeičia (indukcijos laikotarpis paprastai yra 3-4 h); 2-as - kai UIG bandinyje smarkiai padidèja dèl spartaus hidratų nusodinimo ir perëjimo iš amorfinès ị kristalinę formą (Smith et al., 2002; Trtnik et al., 2008), kai tešla ima stingti (greitas struktūros susidarymo laikotarpis, iki 24 h); 3-ias - UIG bandinyje lètai didèja ir stabilizuojasi, bandinyje susidaro hidratacijos produktų karkasas ir bandinys yra visiškai sukietėjęs.

Rezultatai rodo, kad šviežios NA tešlos indukcijos periodas yra trumpiausias - apie 1,8 h, o kontrolinès tešlos NK indukcijos periodas yra šiek tiek ilgesnis $-2,7$ h. Šie rezultatai gerai koreliuoja su rezultatais, gautais tiriant šių tešlų klampą. İ PC tešlą įdejjus SP (C), SP (B) ir SP mišinị, sąveikaujant su MWCNTs cemento mineralų jonų ir hidratacijos produktai pereina ị tirpalą lèčiau, sulètëja struktūros išsivystymas ir indukcijos periodo trukmé pratęsiama atitinkamai iki $3,3 \mathrm{~h}, 3,9 \mathrm{~h}$ ir $4,9 \mathrm{~h}$. Staigiai UIG vertès padidèja po indukcinio periodo, o po 12 $14 \mathrm{~h}$ UIG vertès didèja lètai. 


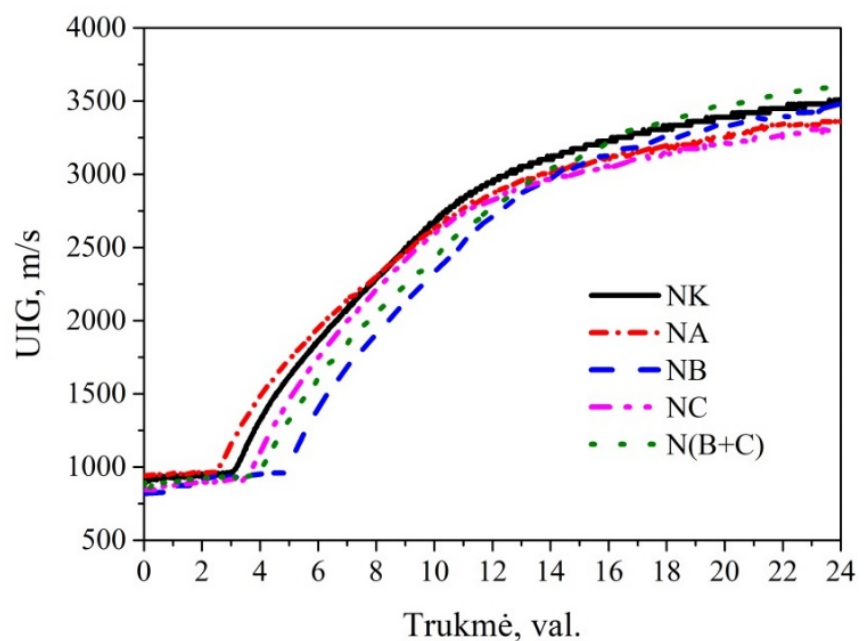

3.24 pav. Plastifikuojančių betono įmaišų ir daugiasienių anglies nano vamzdeliu sąveikos ịtaka cemento tešlų ultragarso impulso sklidimo greičiui priklausomai nuo laiko

Fig. 3.24. Plasticizers and multi-walled carbon nano tubes impact to ultrasound pulse velocity changes in the cement pastes depending on time

Kaip matyti, SP mišinys, palyginti su atskirai naudojamais SP (B) ir SP (C), greitina struktūros susidarymą sparčios naujadarų kristalizacijos metu, ir tai rodo UIG vertès po 15 h, kai jos šioje tešloje didejja greičiau nei kitose. Mažiausios UIG vertès yra NA ir NC sudeečių bandiniuose. Po $24 \mathrm{~h}$ kietejjimo didžiausios UIG vertès yra $\mathrm{N}(\mathrm{B}+\mathrm{C})(3605 \mathrm{~m} / \mathrm{s})$, o mažiausios $-\mathrm{NC}(3305 \mathrm{~m} / \mathrm{s})$ bandiniuose.

\subsubsection{Cemento tešlų hidratacijos procesų tyrimai}

Cemento hidratacijos procesų, atsispindinčių egzoterminès reakcijos (EXO) temperatūros pokyčiuose, tyrimai rodo, kad SP(A), nepaisant silpnai rūgštinio $\mathrm{pH}$, NA tešloje pagreitina hidratacijos procesą beveik 1,3 h (3.25 ir 3.26 pav.), palyginus su kontroline NK tešla.

Tai patvirtina ankstesnius samprotavimus ir tyrimų rezultatus, kad SP (A) sulfato grupès aktyviai reaguoja $\mathrm{su}_{3} \mathrm{~A}$ ir skatina greitesnę hidrataciją. Maksimali EXO temperatūra NA tešloje buvo pasiekta po 5,3 val., tačiau siekè tik $78{ }^{\circ} \mathrm{C}$, o tai yra 13,4 \% mažiau nei kontrolinèje NK tešloje. Maksimali EXO temperatūra $90{ }^{\circ} \mathrm{C}$ NK tešloje buvo pasiekta po 6,67 val. SP mišinys ir SP (B) sumažina $\mathrm{N}(\mathrm{B}+$ C) ir NB tešlų EXO temperatūrą iki $88^{\circ} \mathrm{C}$ ir prailgina $\mathrm{PC}$ hidratacijos procesą atitinkamai iki 7,5 ir 8 val. Maksimalų EXO laiką labiausiai prailgina SP (C), nes $\mathrm{NC}$ tešloje jis pasiekiamas po 8,83 val., o temperatūra atitinkamai siekia $90{ }^{\circ} \mathrm{C}$. 


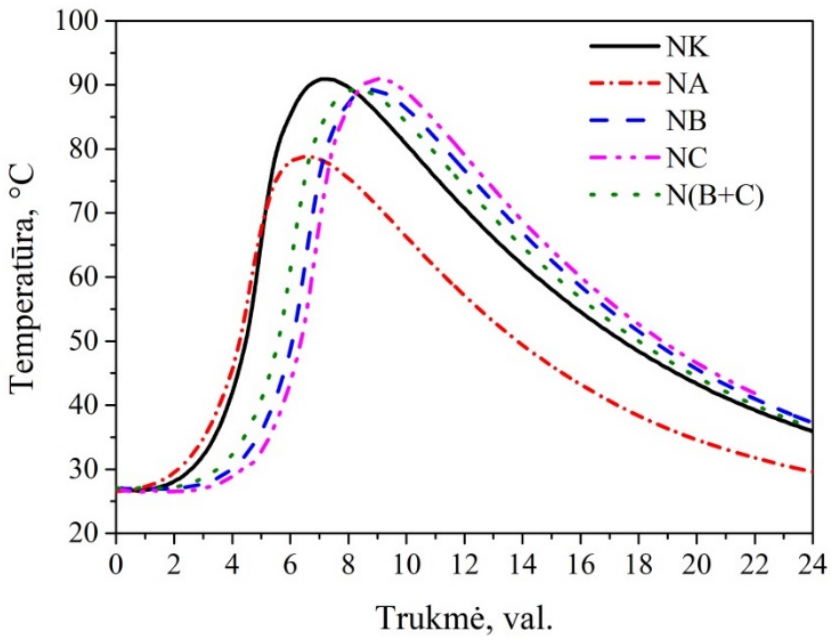

3.25 pav. Plastifikuojančių betono ịmaišų ir daugiasienių anglies nano vamzdelių poveikis cemento tešlų egzoterminès reakcijos temperatūros parametrams priklausomai nuo laiko

Fig. 3.25. Plasticizers and multi-walled carbon nano tubes impact to exothermic reaction temperature progress in the cement pastes depending on time

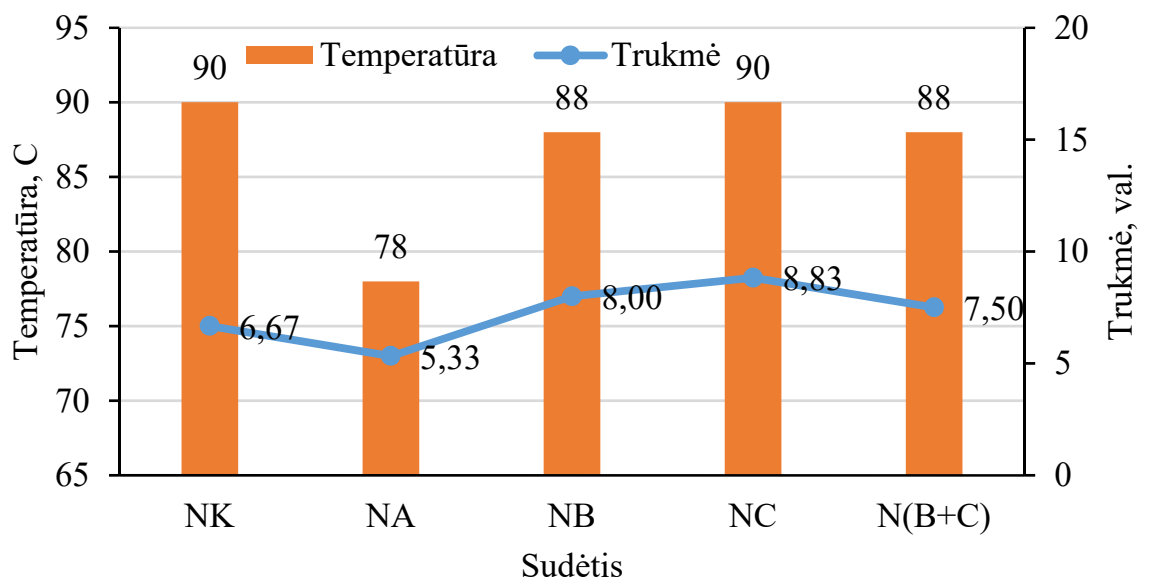

3.26 pav. Plastifikuojančių betono įmaišų ir daugiasienių anglies nano vamzdelių poveikis cemento tešlų egzoterminès reakcijos temperatūrai ir laikui

Fig. 3.26. Plasticizers and multi-walled carbon nano tubes impact to exothermic reaction temperature and time in the cement pastes 
Apibendrinant galima pasakyti, kad SP (A), sąveikaudamas su MWCNTs, žymiai pagreitina, o SP (C) ir SP (B) - sulètina PC tešlų hidratacijos procesą.

\subsubsection{Cemento akmens rentgenografiniai tyrimai}

Sukietejusių cemento akmens NK, NA, NB, NC ir N (B+C) bandinių mineralinė sudètis po 28 paru kietejjimo buvo ịvertinta XRD analizès metodu (3.27 pav.). Visuose tirtuose bandiniuose buvo nustatyti pagrindiniai PC hidratacijos produktai: etringitas, portlanditas, monokarboaliuminatas, kalcio silikato hidratas, kalcitas, belitas, alitas.

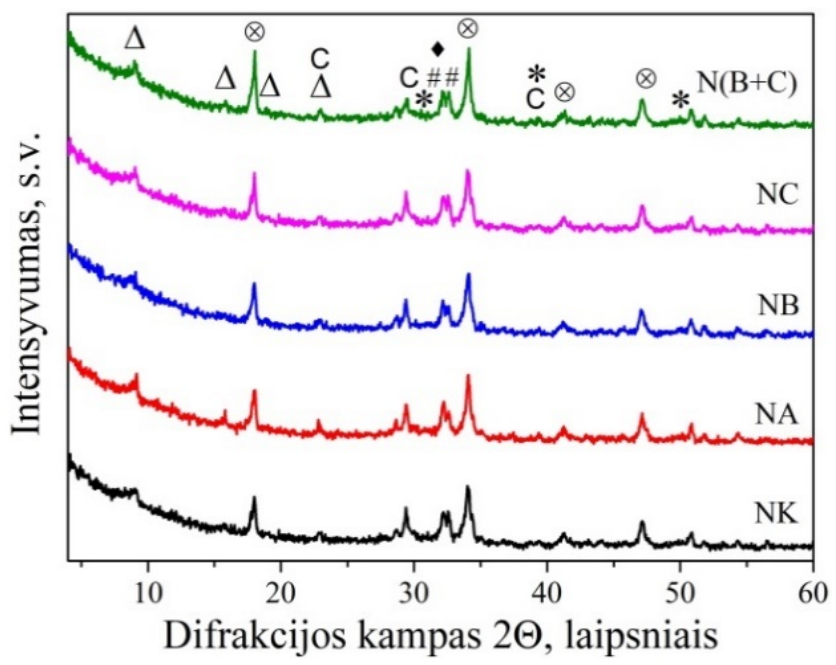

3.27 pav. Cemento akmens rentgenografinè analizè: $\Delta$ - etringitas, $\otimes$ - portlanditas, $\mathrm{C}-$ calcitas, $\#-\mathrm{C}_{2} \mathrm{~S}, \bullet-\mathrm{C}_{3} \mathrm{~S}, *-\mathrm{CSH}$

Fig. 3.27. X-Ray diffraction analysis of cement stone. Key: $\Delta$ - ettringite, $\otimes$ - portlandite, $\mathrm{C}-$ calcite, $\#-\mathrm{C}_{2} \mathrm{~S}, \bullet-\mathrm{C}_{3} \mathrm{~S}, *-\mathrm{CSH}$

Tačiau pastebėta, kad NA bandinyje, palyginti su likusiais, susidaro daug daugiau etringito, kurio smailių intensyvumas yra didesnis nei atitinkamų NK, $\mathrm{NB}, \mathrm{NC}$ ir $\mathrm{N}(\mathrm{B}+\mathrm{C})$ etringito smailių intensyvumas. NA bandinyje portlandito smailès intensyvumas yra šiek tiek mažesnis, palyginti su kitais minètais bandiniais. Yra žinoma, kad $\mathrm{PC}$ hidratacijos metu $\mathrm{C}_{3} \mathrm{~A}$ reaguoja su sulfato jonais (Zhang et al., 2008). I bandinius įdejus SP (A), jo sulfonatų grupès ir PC mineralų sulfato jonai reaguoja su aliuminatine faze ir susidaro didesnis etringito kiekis (Mikanovic \& Jolicoeur, 2008). 


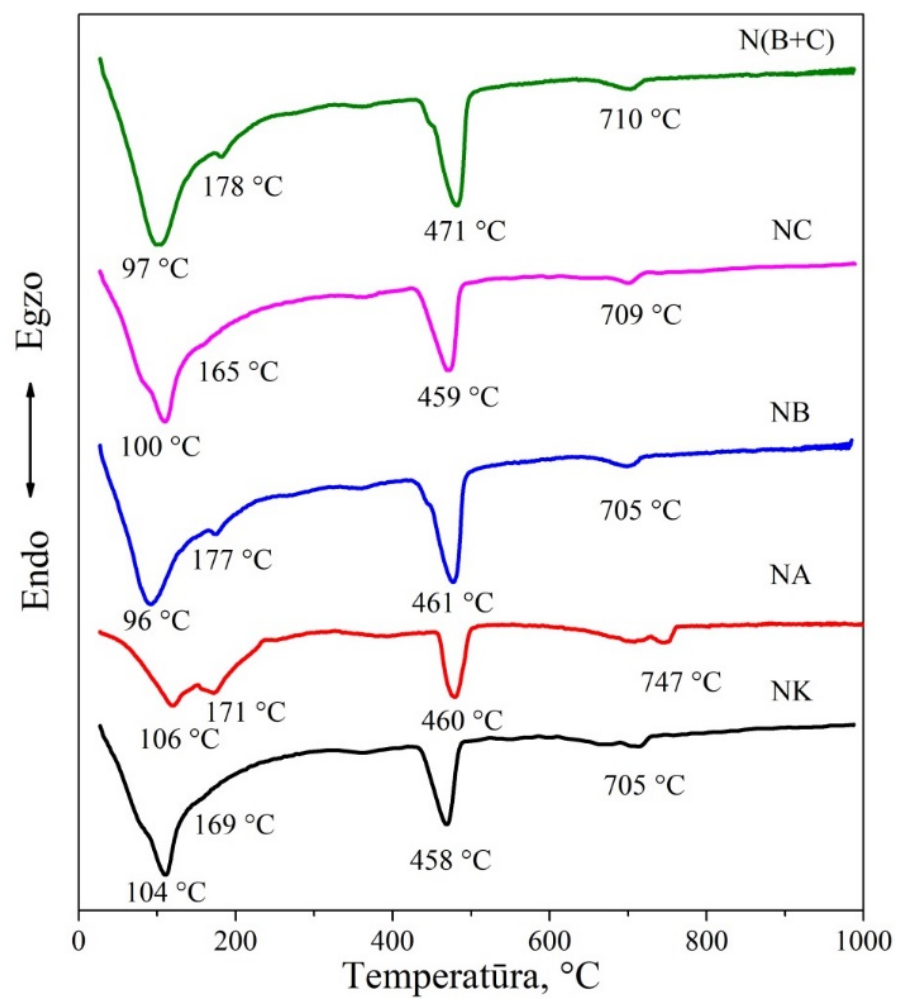

3.28 pav. 28 paras kietejusio cemento akmens su daugiasieniais anglies nano vamzdeliais ir plastifikuojančiomis betono įmaišomis termografinès kreivės

Fig. 3.28. DTA curves for cement stone with multi-walled carbon nano tubes and plasticizers after 28 days of curing

Apibendrinant NB, NC ir N $(B+C)$ bandinių XRD analizès duomenis, pastebèta, kad skirtumai tarp jų yra nedideli, išsiskiria tik N $(B+C)$ bandinio portlandito smailès pikas, kurio intensyvumas yra šiek tiek didesnis. Rentgenografinès analizès rezultatai buvo patvirtinti terminès analizès tyrimais ( 3.28 pav.).

\subsubsection{Cemento akmens termografiniai tyrimai}

Po 28 parų kietejimo buvo atlikta bandinių NK, NA, NB, NC ir N (B + C), DTA analizè. DTA kreivèse (3.28 pav.) matomi trys pagrindiniai endoterminiai efektai, kurių metu fiksuojami didesni masės nuostoliai (3.29 pav.). 


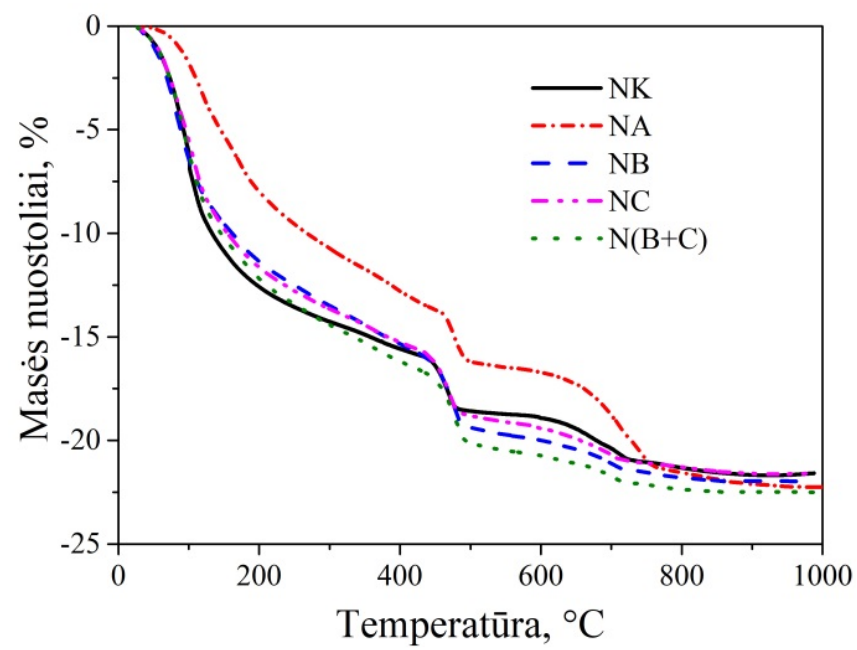

3.29 pav. 28 paras kietejusių bandinių su daugiasieniais anglies nano vamzdeliais ir plastifikuojančiomis betono įmaišomis masès nuostolių kreivès

Fig. 3.29. Mass loss curves for specimens with multi-walled carbon nano tubes and plasticizers after 28 days of curing

Masès nuostoliai iki $450{ }^{\circ} \mathrm{C}$ temperatūros atsiranda dèl laisvojo vandens pasišalinimo (Chen, 2015; Stepkowska, 2006) ir dèl hidratinio vandens praradimo, kai kalcio hidroaliuminatai, etringitas, monokarboaliuminatai bei kalcio silikato hidratas praranda hidratini vandenị (Gabrovšek et al., 2008; Hartman et al., 2006; Zhou \& Glasser, 2001). Pirmas dvigubas endoterminis efektas fiksuojamas 96$220{ }^{\circ} \mathrm{C}$ temperatūros diapazone, gali būti susietas su etringito $\left(160-180{ }^{\circ} \mathrm{C}\right)$, kalcio silikato hidrato, kalcio hidroaliuminatų skilimu (Ashraf et al., 2009; Payá et al., 2003; Sha et al., 1999). Kaip matyti 3.28 paveiksle, NA bandinyje dèl etringito skilimo ši smailè yra ryškesnè nei kituose bandiniuose. Temperatūros intervale nuo 450 iki $550{ }^{\circ} \mathrm{C}$ vyksta portlandito $\mathrm{Ca}(\mathrm{OH})_{2}$, o apie $730{ }^{\circ} \mathrm{C}-$ karbonatu skilimas.

Atlikti TG tyrimai rodo skirtingą hidratų kiekị bandiniuose (3.29 pav.). Masès nuostoliai, susiję su nesurištojo vandens išsiskyrimu ir etringito, monosulfoaliuminato bei CSH tipo fazių hidratų dehidratacija, buvo nustatyti iki $450{ }^{\circ} \mathrm{C}$ ribos (3.30 pav.). 


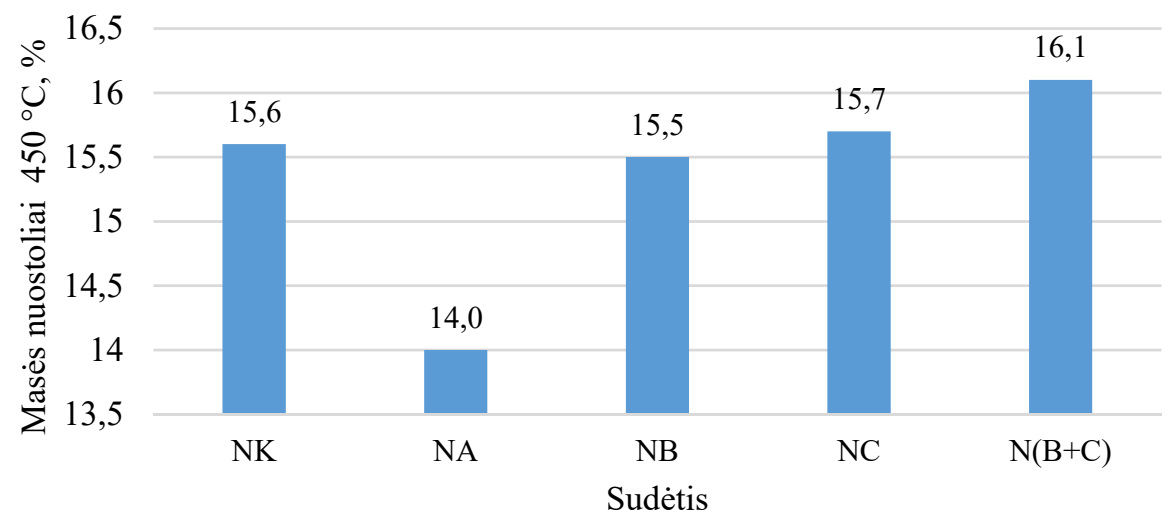

3.30 pav. 28 paras kietejusių bandinių su daugiasieniais anglies nano vamzdeliais ir skirtingomis plastifikuojančiomis betono įmaišomis masès nuostoliai iki $450{ }^{\circ} \mathrm{C}$

Fig. 3.30. Mass losses in 28 days hardened specimens with different plasticizers and multi-walled carbon nano tubes at temperature range up to $450{ }^{\circ} \mathrm{C}$

Palyginus su kontroliniu NK bandiniu, išskyrus NA bandinį, masès nuostoliai padidèja, ypač sudètyse $\mathrm{N}(\mathrm{B}+\mathrm{C})$ ir NB. Nustatyta, kad N $(\mathrm{B}+\mathrm{C})$ bandinio masès nuostoliai yra apytiksliai $4,6 \%$ didesni už NB masès nuostolius ir $8 \%-u z ̌ ~ N K$ bandinius. Masès nuostoliai NA sudètyje yra gerokai (apie 7,5\%) mažesni už kontrolinio NK bandinio. Šis rezultatas rodo, kad SP (A), sąveikaudamas su MWCNTs, smarkiai sumažina cemento hidratacijos laipsnị.

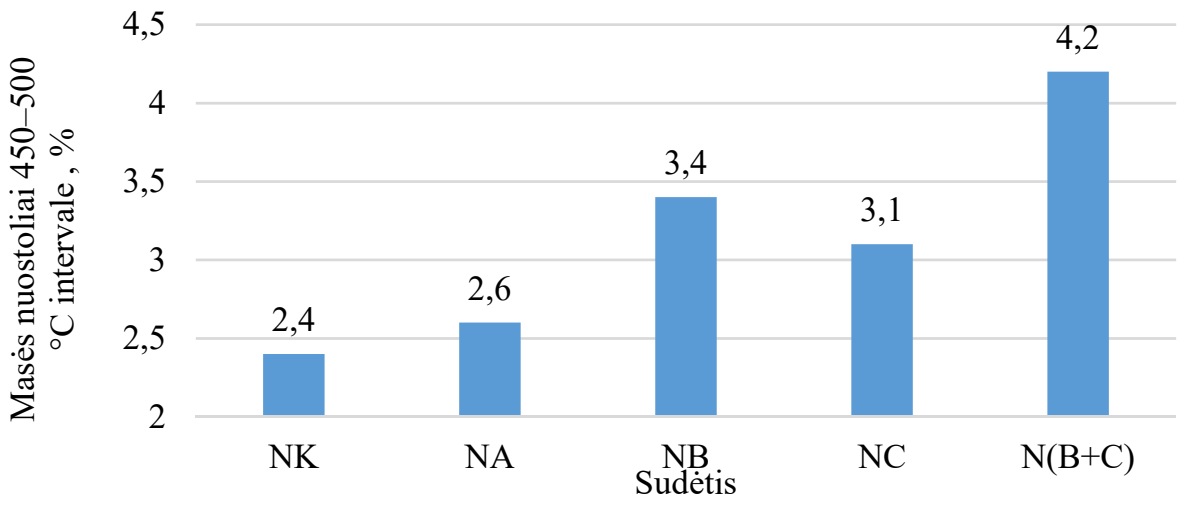

3.31 pav. 28 paras kietejusių bandinių su daugiasieniais anglies nano vamzdeliais ir skirtingomis plastifikuojančiomis betono įmaišomis masės nuostoliai

$$
450-500{ }^{\circ} \mathrm{C} \text { intervale }
$$

Fig. 3.31. Mass losses in 28 days hardened specimens with different plasticizers and multi-walled carbon nano tubes at temperature range $450-500{ }^{\circ} \mathrm{C}$ 
Palyginus su kontroliniu NK ir NA bandiniais, masès nuostoliai, fiksuojami $\mathrm{Ca}(\mathrm{OH})_{2}$ skilimo metu, taip pat yra daug didesni bandiniuose $\mathrm{NB}$ ir $\mathrm{NC}$ (3.31 pav.). Didžiausias masès nuostolis nustatytas $\mathrm{N}(\mathrm{B}+\mathrm{C})$ bandinyje.

Masès nuostolis yra $19 \%$ didesnis nei artimiausiame pagal masès nuostoliu vertes bandinyje NB. Šie rezultatai ịrodo, kad SP mišinys veikia PC hidratacijos procesus ir skatina susidaryti didesnį hidratų kiekị negu sudètyse su pavieniais SP. Apibendrinant duomenis, pastebèta, kad bandinys su SP mišiniu $(\mathrm{N}(\mathrm{B}+\mathrm{C}))$ turèjo didžiausias masės nuostolių vertes visuose temperatūros intervaluose, susijusiuose su dehidratacijos procesais. Šie DTA/TG ir masès kreivių sąryšiai buvo patvirtinti atlikus gniuždymo stiprio tyrimus.

\subsubsection{Cemento akmens mechaninių savybių tyrimai}

MWCNTs ir SP įmaišų įtakos bandinių gniuždymo stipriui nustatyti buvo suformuoti vienodo sklidumo, tačiau atitinkamai skirtingo V/C santykio bandiniai (sudètys pateiktos 2.8 lenteleje). Po 2 kietejjimo paru atlikti tyrimai parodè, kad kontrolinio bandinio (WN), sudètyje neturinčio $\mathrm{SP}$, gniuždymo stiprio verte buvo mažiausia - $66 \mathrm{MPa}$ (3.32 pav.).

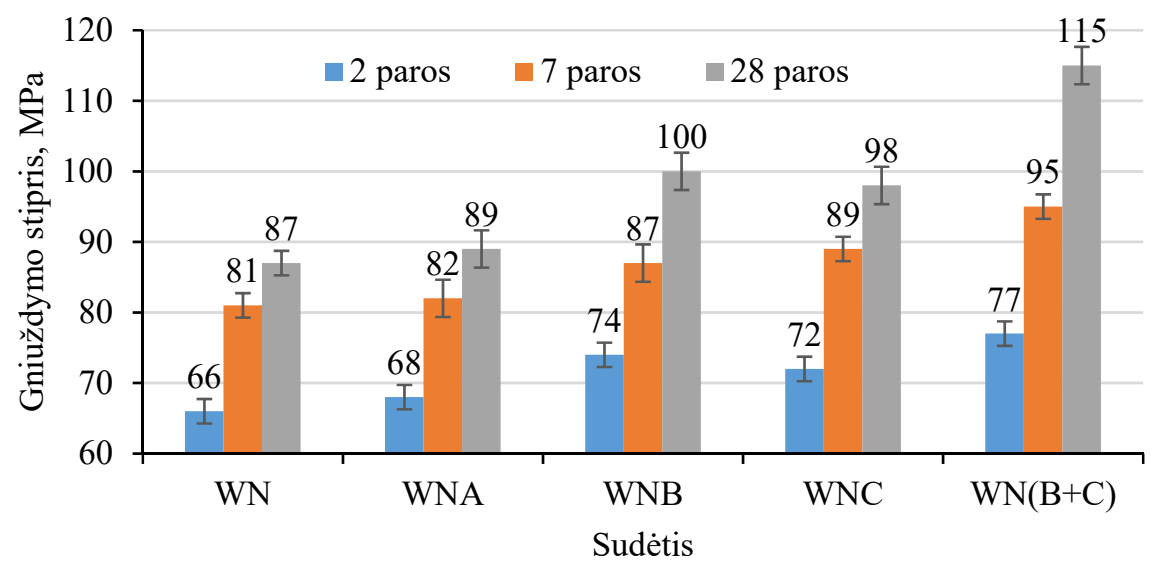

3.32 pav. Plastifikuojančių betono įmaišų ir daugiasienių anglies nano vamzdelių ịtaka cemento akmens gniuždymo stipriui

Fig. 3.32. Plasticizers and multi-walled carbon nano tubes impact to the compressive strength of specimens

Didžiausias gniuždymo stiprio didejimas (16\%), palyginti su kontroliniu bandiniu, nustatytas bandiniuose su SP mišiniu (WN $(B+C)$ ). Bandinių su SP (A), SP (B) ir SP (C) gniuždymo stipris, palyginus su kontroliniu bandiniu, padidejo $3 \%, 8 \%$ ir $9 \%$. Tos pačios tendencijos buvo stebimos ir po 7 parų kietejimo. 
Kontroliniame bandinyje WN gniuždymo stipris pasiekè $81 \mathrm{MPa}$ vertę, o bandiniuose su SP mišiniu gniuždymo stipris yra 17,3 \% didesnis. Bandinių su SP (A), SP (B) ir SP (C) gniuždymo stipris padidejo atitinkamai 1,2 \%, 7,4 \% ir 9,8 \%. Po 28 parų kietejjimo kontrolinių bandinių gniuždymo stipris siekė $87 \mathrm{MPa}$. Bandinių su SP (A), SP (B) ir SP(C) gniuždymo stipris padidejo atitinkamai 2,3\%, 12,6\% ir 14,9 \%, o bandinių su SP mišiniu - net 32,2 \%. Tos pačios tendencijos naudojant SP mišinị pastebètos ir kituose tyrimuose (Demidova-Buizinienè \& Pundienè, 2015; Johann Plank et al., 2009). Atlikti tyrimai parodè, kad po 28 parų kietejjimo tokių bandinių gniuždymo stipris apytiksliai padidejo $10-15 \%$, nes buvo sumažintas vandens kiekis sudètyje, taip pat susidare daugiau hidratacijos produktų.

Atliekant lenkimo stiprio bandymus buvo gauti skirtingi rezultatai. Geriausi rezultatai buvo gauti naudojant WNA sudetti su SP (A) (3.33 pav.). Palyginus su kontroliniu bandiniu WN, lenkimo stipris bandinyje WNA su SP (A) padideja po 2,7 ir 28 paru kietejjimo atitinkamai $8 \%, 3 \%$ ir $7 \%$. Bandiniuose WNB su SP (B), WN (B+C) su SP mišiniu ir bandinyje WNC su SP (C) stipris lenkiant padidejo $5,1-8,6$ intervale po 2 parų kietejjimo, $0,9-1,6 \%$ po 7 parų ir $2-6 \%$ po 28 parų kietèjimo.

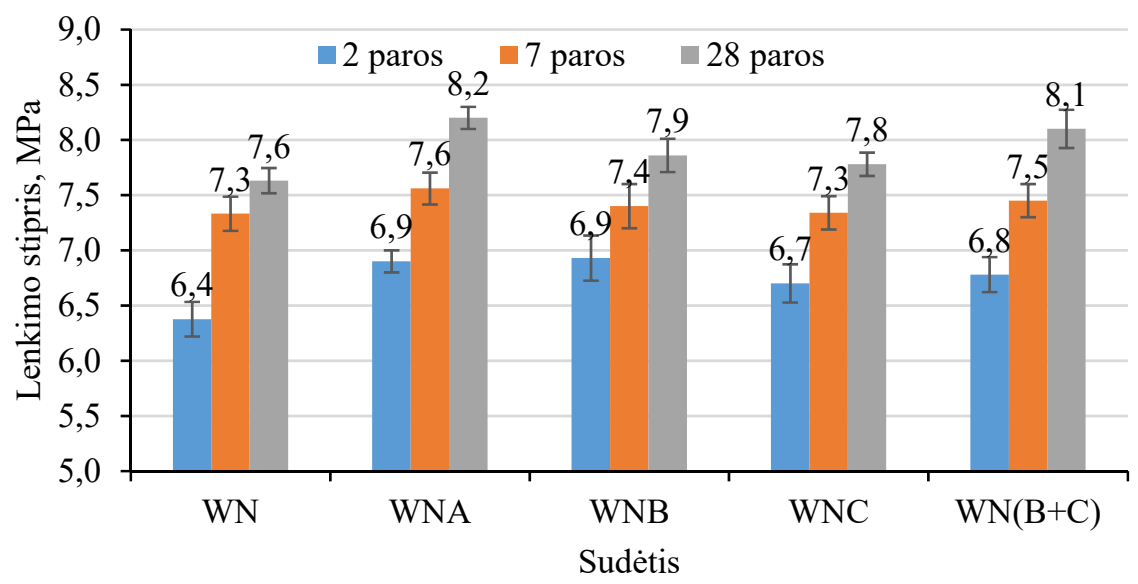

3.33 pav. Plastifikuojančių betono įmaišų ir daugiasienių anglies nano vamzdelių įtaka bandinių lenkimo stipriui

Fig. 3.33. Plasticizers and multi-walled carbon nano tubes impact to flexural strength of specimens

Šie rezultatai rodo, kad galimai dèl etringito ir nanovamzdelių mechaninès sąveikos, kai etringito adatėlèse susipina nanovamzdeliai, WNA atsiranda MWCNTs armavimo efektas. 


\subsection{Daugiasienių anglies nano vamzdelių, plastifikuojančių betono i̇maišų mišinio ir orą itraukiančios įmaišos poveikio cementinei matricai tyrimai}

Kitu etapu buvo tyrinėjamas OIP kiekio poveikis bandiniams su SP ir MWCNTs. Šiuo tikslu buvo suformuotos sudėtys su SP, skirtingais MWCNTs kiekiais ir, remiantis literatūros šaltiniais bei gamintojo nurodymais, parinktu OIP kiekiu.

\subsubsection{Cementinès matricos reologinès savybẻs}

Abiejų įmaišų (SP mišinio ir OIP) ir MWCNTs sąveikos cemento tešloje rezultatas pateiktas 3.34 paveiksle. Matome, kad OIP įmaiša M-0SA tešloje (be MWCNTs priedo) padidina pradinę klampą, lyginant su tešla tik su SP mišiniu. Matavimo pabaigoje klampa didèja iki $4750 \mathrm{MPa} \cdot \mathrm{s}$. Toki poveiki patvirtina ir kitų mokslininkų tyrimai (Šeputytè-Jucikè, 2016; Sinica, 2001). Priešingai nei tešlose vien su SP ir MWCNTs, dèl OIP sąveikos su šiais priedais klampa dideja.

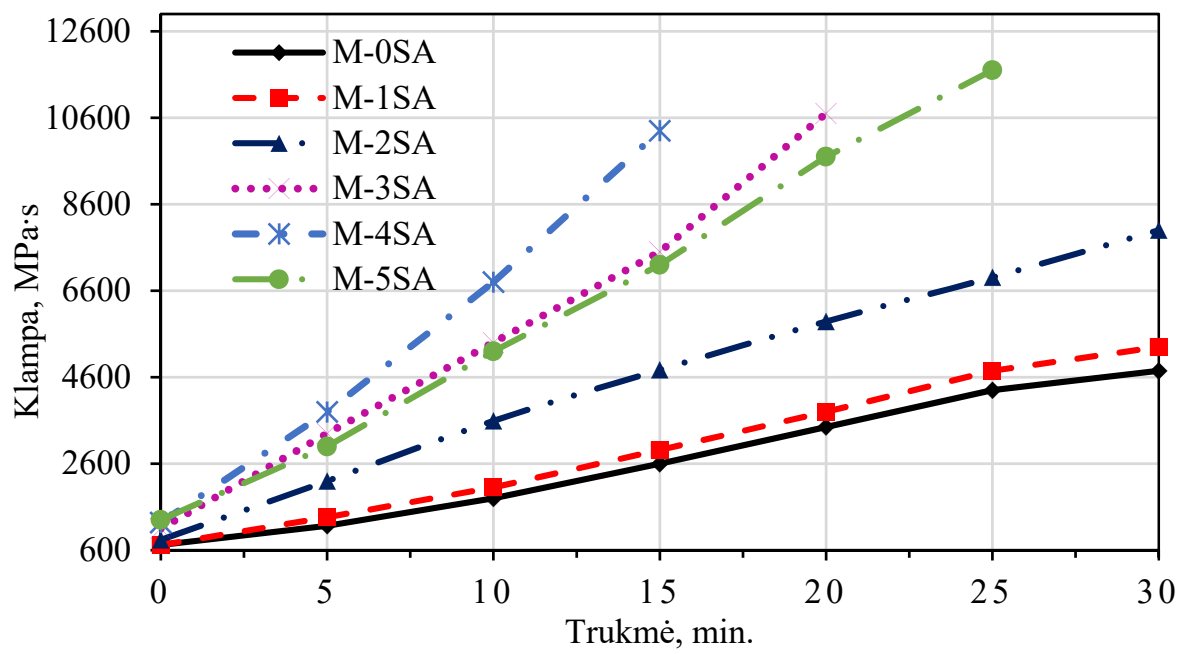

3.34 pav. Daugiasienių anglies nano vamzdelių kiekio poveikis cemento tešlų su plastifikuojančių betono įmaišų mišiniu ir orą ịtraukančia ịmaiša, klampai

Fig. 3.34. Cement pastes with plasticizers blend and air-entraining viscosity, depending on the amount of multi-walled carbon nano tubes

Lyginant suděčių M-1SA ir M-2SA tešlas, turinčias OIP, su tešlomis, turinčiomis mažiausius MWCNTs kiekius $(0,00005$ ir $0,0005 \%)$ ir SP mišinị 
(3.22 pav.), matyti, kad tešlų pradinè klampa didejja nuo 1,5 iki 2,3 karto, tačiau jau po 4-7 min. klampa sparčiai kyla ir po $30 \mathrm{~min}$. pasiekia 5300 ir $7980 \mathrm{MPa} \cdot \mathrm{s}$ vertę, o tai yra 2,3 ir 3,6 karto daugiau nei bandinių be OIP.

M-3SA, M-4SA, ir M- 5SA sudèčių tešloms buvo nustatytos aukščiausios 1200-1280 MPa·s pradinès klampos vertès, kurios po 4-6 min. jau buvo išaugusios dvigubai. Tačiau MWCNTs kiekio poveikis klampos augimui yra skirtingas. M-3SA ir M-4SA tešlose didejjantis MWCNTs greitai didina klampą, ir maksimali prietaiso klampos matavimo riba (12000 MPa.s) pasiekiama po 22 ir $17 \mathrm{~min}$. M-5SA tešloje klampos didejimo tempai ne tokie greiti. Maksimali klampa šios sudèties tešloje pasiekiama po $26 \mathrm{~min}$. Šie rezultatai patvirtina, kad sąveikaujant su OIP yra tik tam tikras MWCNTs $(0,005-0,05 \%)$ kiekis, su kuriuo per trumpiausią laiką pasiekiama didžiausia klampos vertè. Didejjant MWCNTs kiekiui PC tešloje, OIP kartu su MWCNTs sudaro burbuliukų ir plaušelių struktūrą, didinančią klampą.

\subsubsection{Cementinès matricos tankis}

Sukietejusio kontrolinio M-OSA bandinio tankis siekia $1550 \mathrm{~kg} / \mathrm{m}^{3}$ (3.35 pav.). Didinant MWCNTs kieki (nuo 0,00005 iki 0,5\%) bandinių tankis, lyginant su M-0SA bandiniu, mažeja atitinkamai 3,3 \%, 7,1 \%, 10,1\%, 11,2 \% ir 10,1 \%. Didinant MWCNTs kieki iki $0,05 \%$, tankis mažèja labiausiai. Dar didinant MWCNTs iki 0,5 \%, bandinio tankis jau nemažèja.

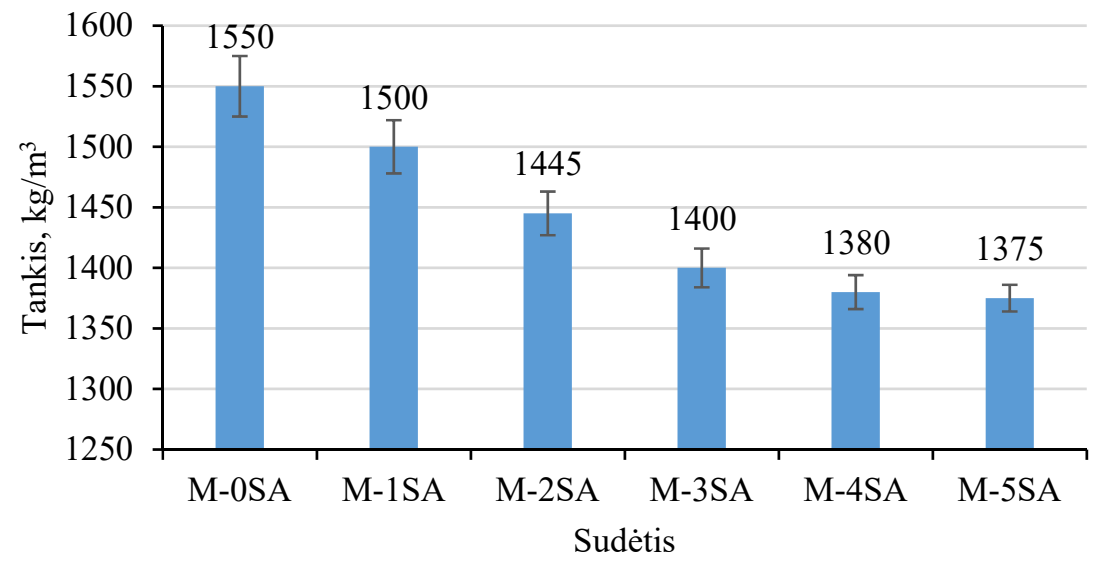

3.35 pav. Daugiasienių anglies nano vamzdelių kiekio poveikis 28 paras kietejusių bandinių su plastifikuojančių betono įmaišų mišiniu ir orą įtraukančia ịmaiša, tankiui Fig. 3.35. Density of 28 days hardened cement stone with plasticizers blend and airentraining, depending on the amount of multi-walled carbon nano tubes 
Šie tyrimai rodo, kad MWCNTs dèl sąveikos su OIP keičia bandinių struktūrą ir didina porų kiekị bandinio tūryje.

\subsubsection{Cementinès matricos vandens sugertis ir poringumas}

Buvo atlikti 28 paras kietejusių M-0SA-M-5SA sudèčų bandinių vandens sugerties kinetikos tyrimai (3.36 pav.). Pastebimas gana aiškus ryšys tarp bandinių tankio ir vandens iggeriamumo rezultatų. Nustatyta, kad bandinių su MWCNTs priedu vandens igeriamumas yra 1,81, 5,5, 11,5, 16, 17,8 \% didesnis, palyginti su kontroliniu bandiniu M-0SA. Bandymų rezultatai rodo, kad kuo didesnis MWCNTs kiekis bandinyje, tuo didesnès vandens sugerties vertès. Galimai taip yra dèl bandinių struktūrose MWCNTs ir dèl OIP sąveikos susidariusio didesnio porų kiekio.

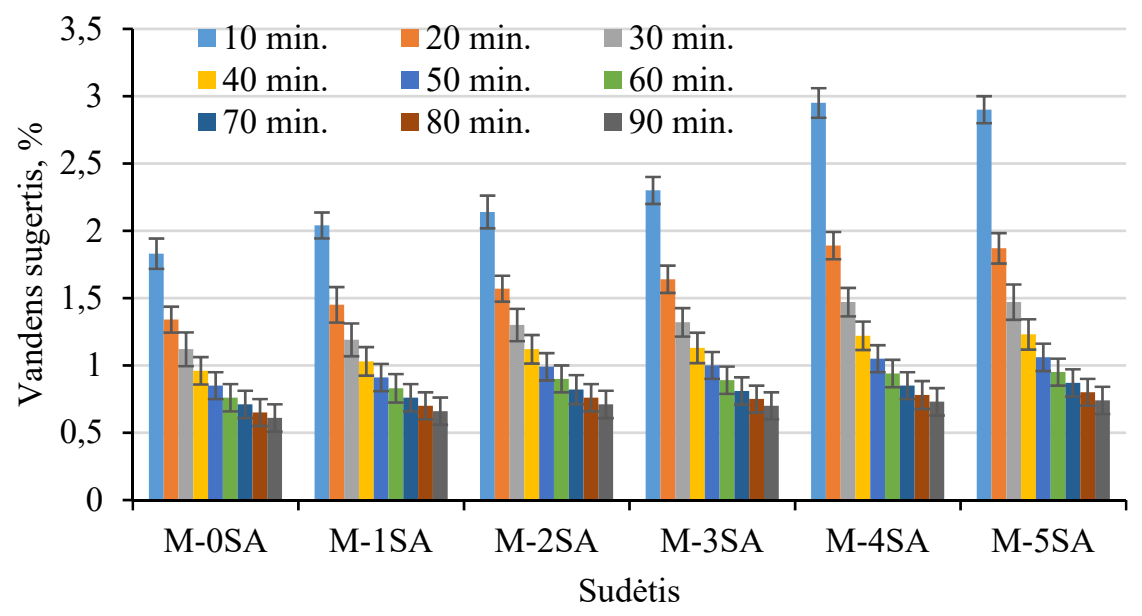

3.36 pav. Daugiasienių anglies nano vamzdelių kiekio poveikis 28 paras kietejusių bandinių su plastifikuojančiu betono įmaišų mišiniu ir orą įtraukančia įmaiša vandens sugerčiai

Fig. 3.36. Absorption of 28 days hardened cement stone with plasticizers blend and airentraining, depending on the amount of multi-walled carbon nano tubes

Bandinių ilgalaikès ( 3 paros) vandens sugerties (3.37 pav. ) tyrimai rodo, kad, didèjant MWCNTs kiekiui bandinio sudètyje, sugerties vertès didèja. Mažesni MWCNTs kiekiai $0,00005 \%$ ir $0,0005 \%$ neženkliai didina vandens sugertị iki $5,2 \%$. Didesni MWCNTs kiekiai $0,005-0,5 \%$ padidina vandens sugerti iki $15,2 \%$, lyginant su kontroliniu M-OSA bandiniu. Toks vandens sugerties padidèjimas bandiniuose siejamas su bandinių tankio mažejimu, nes aiškiai matoma tendencija - mažèjant bandinių tankiui, vandens sugertis didèja. 


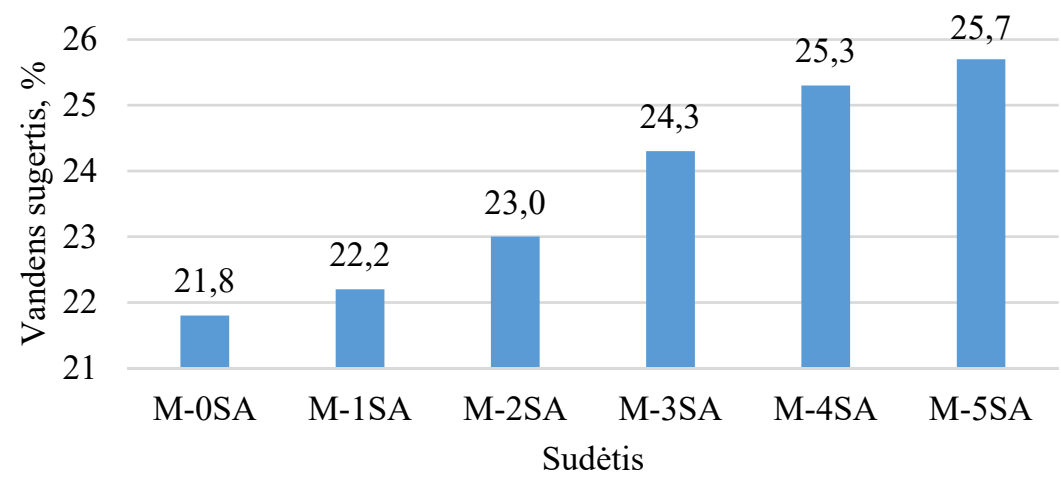

3.37 pav. Daugiasienių anglies nano vamzdelių kiekio poveikis 28 paras kietejusių bandinių su plastifikuojančių betono įmaišų mišiniu ir orą įtraukančia ịmaiša ilgalaikei (3 paros) vandens sugerčiai

Fig. 3.37. Long term ( 3 days) absorption of 28 days hardened cement stone with plasticizers blend and air-entraining, depending on the amount of multi-walled carbon nano tubes

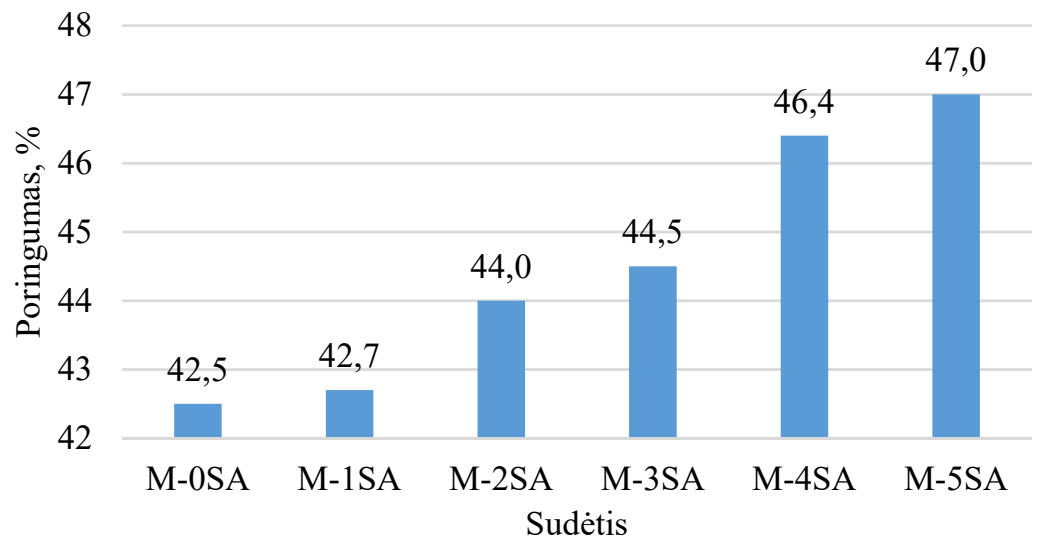

3.38 pav. Daugiasienių anglies nano vamzdelių kiekio poveikis 28 paras kietejusių bandinių su plastifikuojančių betono įmaišų mišiniu ir orą įtraukančia įmaiša atvirajam poringumui

Fig. 3.38. Porosity of 28 days hardened cement stone with plasticizers blend and airentraining, depending on the amount of multi-walled carbon nano tubes

Atvirojo poringumo, sukelto MWCNTs, susidarymo raidą galima pamatyti 3.38 paveiksle. SP, OIP ir MWCNTs sąveika cemento tešloje skatina atvirujų ir uždarųų porų susidarymą, lemiantị bandinių tankio mažejjimą. Sukietejjusių bandinių atvirasis poringumas padidèja nuo 42,5\% (kontroliniu M-0SA atveju) iki 
$47 \%$ M-5SA atveju. Manoma, kad atvirojo poringumo padidejimas yra labiausiai sukeltas dèl OIP ir MWCNTs sąveikos. Didinant MWCNTs kiekị, ị cemento tešlą su OIP yra ịtraukiama daugiau oro. Panašius tyrimus atliko ir kiti mokslininkai (Zhang \& Liu, 2019). Jų nuomon,e MWCNTs gali labai pagerinti putbetonio porų ir oro tuštumų sienelių kokybę.

\subsubsection{Cementinès matricos makro- ir mikrostruktūrai tyrimai}

Norint ịvertinti bandinių tankio, vandens igeriamumo ir atvirojo poringumo tyrimų rezultatus, buvo atlikti bandinių makrostruktūros tyrimai. Bandinių makrostruktūros vaizdai pateikti 3.39 paveiksle.

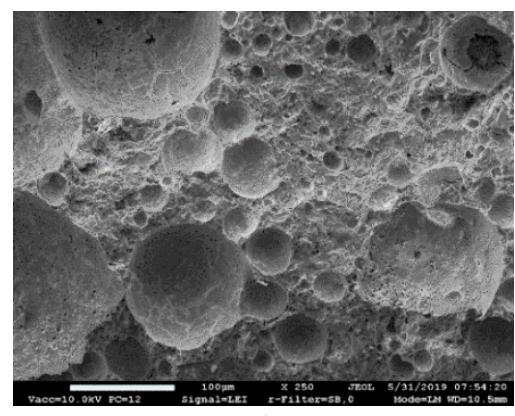

a)

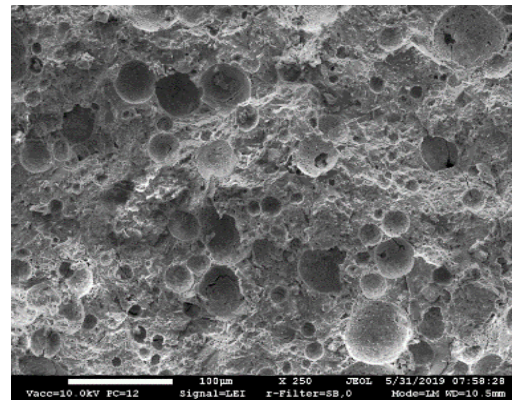

c)

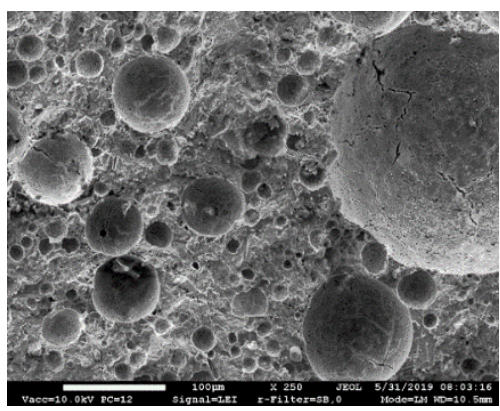

b)

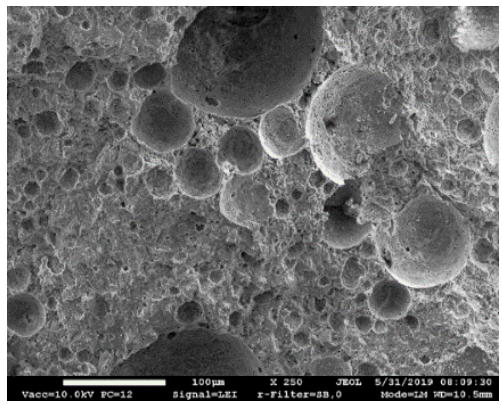

d)

3.39 pav. Sukietejusių bandinių su daugiasieniais anglies nano vamzdeliais, plastifikuojančių betono įmaišų mišiniu ir orą įtraukančia ịmaiša makrostruktūra (didinimas - ×250): a) M-0SA ; b) M-1SA; c) M-3SA, d) M-5SA

Fig. 3.39. Cement stone with plasticizers blend and air-entraining macrostructure, depending on the amount of multi-walled carbon nano tubes (magnification $-\times 250$ ):

a) M-0SA; b) M-1SA; c) M-3SA, d) M-5SA 


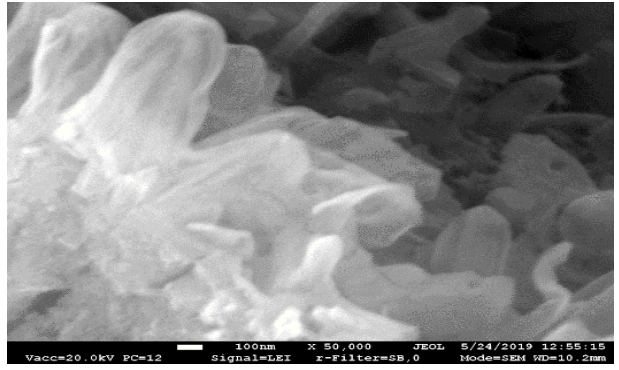

a)

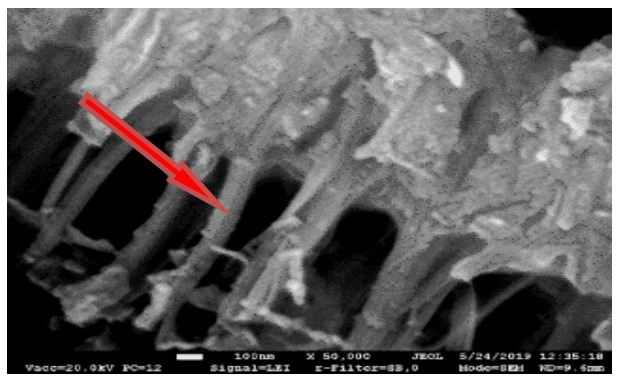

c)

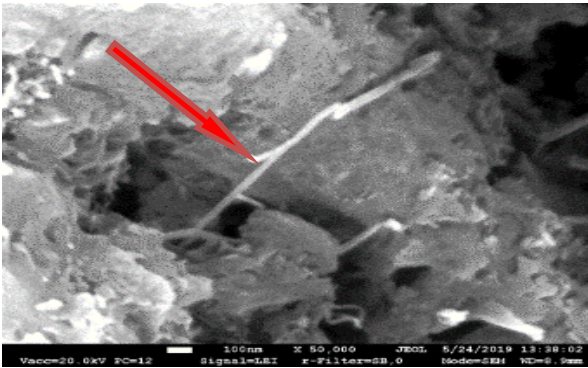

b)

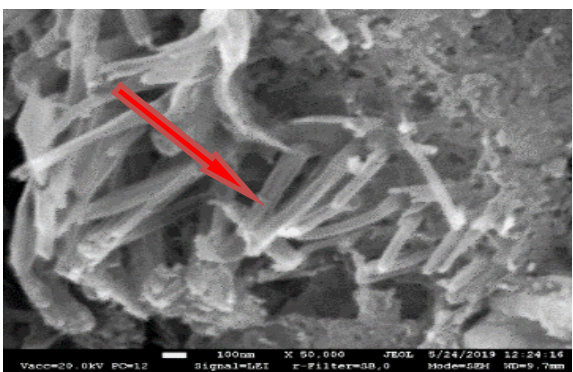

d)

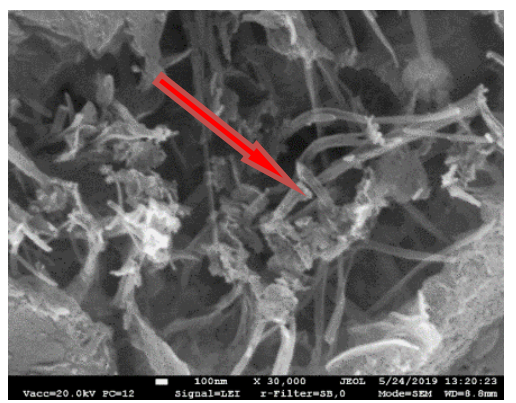

e)

3.40 pav. 28 paras kietejusių bandinių su daugiasieniais anglies nano vamzdeliais, plastifikuojančių betono įmaišų mišiniu ir orą ịtraukančia įmaiša mikrostruktūra:

a) M-0SA (didinimas $-\times 50000$ ); b) M-1SA (didinimas $-\times 50000$ ); c) M-3SA (didinimas $\times 50000$ ); d) M-5SA (didinimas $-\times 50000$ ); e) M-5SA

(didinimas $-\times 30000)$

Fig. 3.40. Cement stone with plasticizers blend and air-entraining microstructure, depending on the amount of multi-walled carbon nano tubes: a) M-0SA (magnification $\times 50000$ ); b) M-1SA (magnification $-\times 50000$ ); c) M-3SA (magnification $-\times 50000$ ); d) M5SA (magnification $-\times 50000$ ); e) M-5SA (magnification $-\times 30000$ ) 
Matome, kad kontroliniame M-0SA (be MWCNTs) ir M-1SA su $0,00005 \%$ MWCNTs bandiniuose vyrauja stambios poros (3.39 pav. a ir b). M-OSA (3.39 pav. a) bandinyje vyrauja stambios $120-300 \mu \mathrm{m}$ dydžio poros, šiek tiek mažiau pastebèta 40-60 $\mu \mathrm{m}$ dydžio porų. M-1SA bandinyje matoma šiek tiek mažiau stambių 150-250 $\mu \mathrm{m}$ dydžio porų ir daugiau 30-60 $\mu \mathrm{m}$ dydžio porų (3.39 pav. b). Bandinyje M-1SA smulkesnių porų yra daugiau nei M-0SA, tačiau abiem atvejais matyti, kad bandiniuose smulkesnių nei $10 \mu \mathrm{m}$ porų yra labai mažai.

Bandinio M-3SA (3.39 pav. c) su 0,005 \% MWCNTs struktūra keičiasi, nèra stambių porų. Visame bandinio tūryje vyrauja tolygiai pasiskirsčiusios 50 $20 \mu \mathrm{m}$ dydžio poros.

Matyti, kad bandinyje (M-5SA) su maksimaliu MWCNTs kiekiu (3.39 pav. d) šalia smulkesnių porų susidaro ir didesnių. Galima teigti, kad OIP ir MWCNTs sąveika skatina poras susidaryti bandiniuose. Tolygiausia porų struktūra gaunama bandinyje su 0,005 \% MWCNTs kiekiu (3.39 pav.c). Šiuos tyrimus patvirtina Zhang and Liu (2019) darbas, kuriame konstatuota, kad MWCNTs gali labai pagerinti putbetonio porų ir oro tuštumų sienelių kokybę bei jų stiprį, sumažinti mikroporų ir oro tuštumų skaičių, jų dydị, užtikrinti tolygų tuštumų pasiskirstymą.

Ištyrinejjus mikrostruktūros vaizdus (3.40 pav.) matyti, kad kontroliniame M-0SA bandinyje (3.40 pav. a pav.) matomi hidratacijos produktai, augantys vidineje poros zonoje. Juos galima priskirti etringitui arba CSH. M-1SA bandinyje (3.40 pav. b) su 0,00005\% MWCNTs vidineje poros dalyje matomi pavieniai MWCNTs plaušeliai. Tačiau kai MWCNTs kiekis bandinyje padidinamas iki su 0,005 \% (3.40 pav. c) matyti, kad poroje esantis MWCNTs kartu su cemento hidratacijos produktais supina gana taisyklingą armuojamaji tinklą, užimantị visą poros tūrị. Toks mikrostruktūros susidarymas gali paveikti ir bandiniu stiprio vertes. Kai MWCNTs kiekis bandinyje yra 0,5\% (3.40 pav. d ir e), MWCNTs plaušeliai išsidèsto gana chaotiškai.

\subsubsection{Cementinès matricos gniuždymo stiprio tyrimai}

Yra žinoma, kad OIP įmaiša smarkiai mažina bandinių tankị ir stiprị. M-OSA bandinių gniuždymo stipris po 2 parų kietejjimo siekia $34 \mathrm{MPa}$. Bandinių su 0,00005$0,005 \%$ MWCNTs gniuždymo stipris siekia $36 \mathrm{MPa}$, t. y. $6 \%$ didesnis, lyginant su M-OSA (3.41 pav.). Tokias pačias tendencijas nurodè ir kiti mokslininkai (Abu Al-Rub et al., 2012; Laukaitis et al., 2012; Makar \& Chan, 2009; Tamimi et al., 2016; Wang et al., 2013; Xu et al., 2015; Yakovlev et al., 2006, 2013), kuri ịrodé, kad maži MWCNTs kiekiai didina gniuždymo stiprị. 


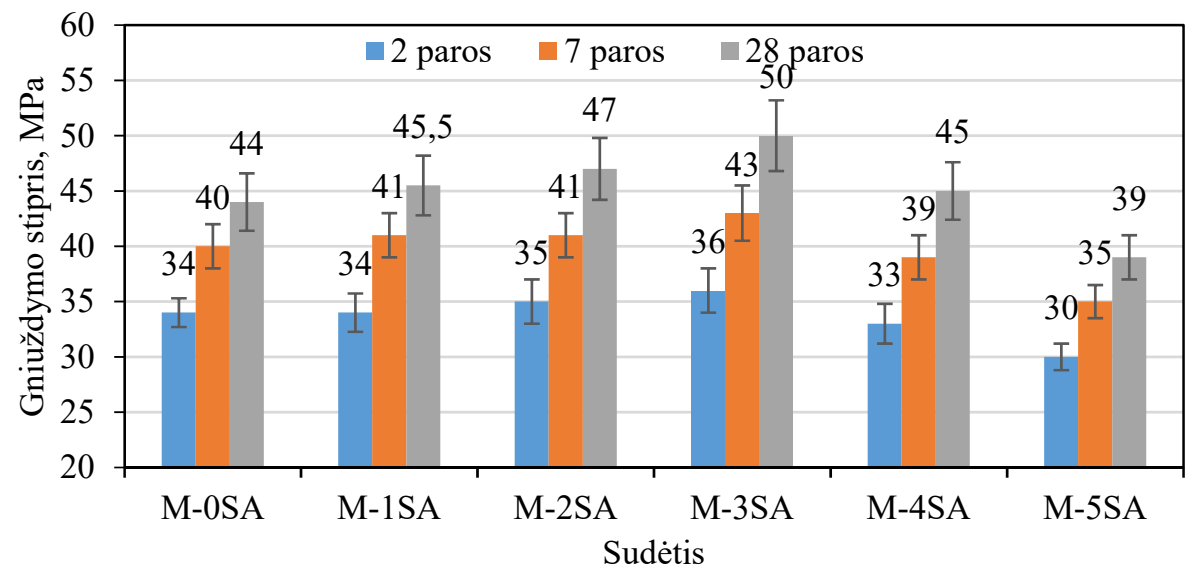

3.41 pav. Daugiasienių anglies nano vamzdelių kiekio poveikis bandinių su plastifikuojančių betono įmaišų mišiniu ir orą îtraukančia įmaiša gniuždymo stipriui

Fig. 3.41. Compressive strength of cement stone with plasticizers blend and airentraining, depending on the amount of multi-walled carbon nano tubes

Dar tiksliau nurodo Zou et al., (2015) - tik mažesni MWCNTs kiekiai (iki $0,1 \%$ sudèties) didina bandiniu gniuždymo stiprį. MWCNTs suděčiu su $0,05 \%$ ir 0,5\% MWCNTs kiekiu gniuždymo stipris sumažeja nuo 33 iki $30 \mathrm{MPa}$. Tai patvirtina ir kitų tyrèjų atlikti tyrimai, nurodantys, kad didesni MWCNTs kiekiai mažina gniuždymo stiprị. Tačiau gniuždymo stipris taip pat labai priklauso ir nuo OIP prigimties. Naudojant skirtingos prigimties OIP, bandinių gniuždymo stipris gali skirtis dvigubai, priklausomai nuo to, kokio dydžio burbuliukai susidaro maišant, todèl Shao et al. (2017) nurodo, kad OIP gerokai mažina kompozicinių cementinių medžiagų, armuotų MWCNTs, gniuždymo stiprị. Taip pat nurodoma, kad didelę ịtaką turi OIP $\mathrm{pH}$ vertès, reguliuojančios tarpusavio traukos jègas cemento tešloje.

Todèl, remiantis atliktais tyrimais, manyti, kad visų trijų OIP, SP ir MWCNTs sąveika formuoja porų struktūrą ir atitinkamai atsiliepia bandinių stiprumo savybèms.

Po 7 parų kietejimo matomas akivaizdus $15-19 \%$ visų bandinių gniuždymo stiprio padidejimas, lyginant su kietejusiais 2 paras bandiniais, tačiau anksčiau pastebètos MWCNTs kiekio poveikio gniuždymo stipriui tendencijos išlieka tokios pačios. Po 28 parų kietejjimo bandinių su 0,00005-0,005 \% MWCNTs gniuždymo stipris padidejo iki $9 \%$ ir siekia 45,5-50 MPa. Šie rezultatai koreliuoja su rezultatais, pateiktais Metaxa et al. (2012) tyrime. MWCNTs kiekị padidinus iki $0,05 \%$ ir $0,5 \%$, gniuždymo stipris siekia 45 ir $39 \mathrm{MPa}$, t. y. 0,5\% MWCNTs atveju gniuždymo stipris sumažejo iki $12,8 \%$, palyginus su kontroliniu M-0SA 
bandiniu. Tokios pačios tendencijos pastebètos Zhang and Liu (2019) tyrime, kuriame autoriai nurodo, kad didesnis nei $0,2 \%$ MWCNTs kiekis bandinių gniuždymo stiprio nedidina, o dar didesni MWCNTs kiekiai ( $0,35 \%$ nuo cemento masès) ženkliai mažina bandinių gniuždymo stiprį. Kiti tyrèjai nurodo, kad didesni (0,3-1 \%) MWCNTs kiekiai sumažina bandinių gniuždymo stiprị po 28 parų $(\mathrm{Hu}$ et al., 2014; Ke et al., 2009; Melo et al., 2011) dèl bandinio mikrostruktūroje atsiradusių mažų itrūkių ir nustatytos MWCNTs aglomeracijos aplink cemento grūdelius. Dèl šios aglomeracijos vyksta tik dalinè cemento hidratacija ir susidaręs hidratuotas produktas turi silpnus ryšius. Apibendrinus matyti, kad po 2, 7 ir 28 parų kietėjimo mažesni MWCNTs (iki 0,005 \%) kiekiai, sąveikaudami su OIP, padidina gniuždymo stiprị 6 ir $9 \%$, o didesni $(0,05$ ir $0,5 \%)$ MWCNTs kiekiai yra neefektyvūs, nes mažina gniuždymo stiprio vertes $3-12,8 \%$.

\subsubsection{Cementinès matricos struktūrinio efektyvumo rodiklis}

Kaip nurodyta literatūros šaltiniuose (Ke et al., 2009), putbetonių ar skiedinių gniuždymo stipris labai koreliuoja su sausuoju tankiu, ir šis ryšys dažniausiai apibūdinamas vadinamuoju struktūriniu efektyvumu (stiprio ir tankio santykiu). Šis rodiklis gerai apibūdina priedų ir ịmaišų poveikị bei padeda pasirinkti optimalius jų kiekius.

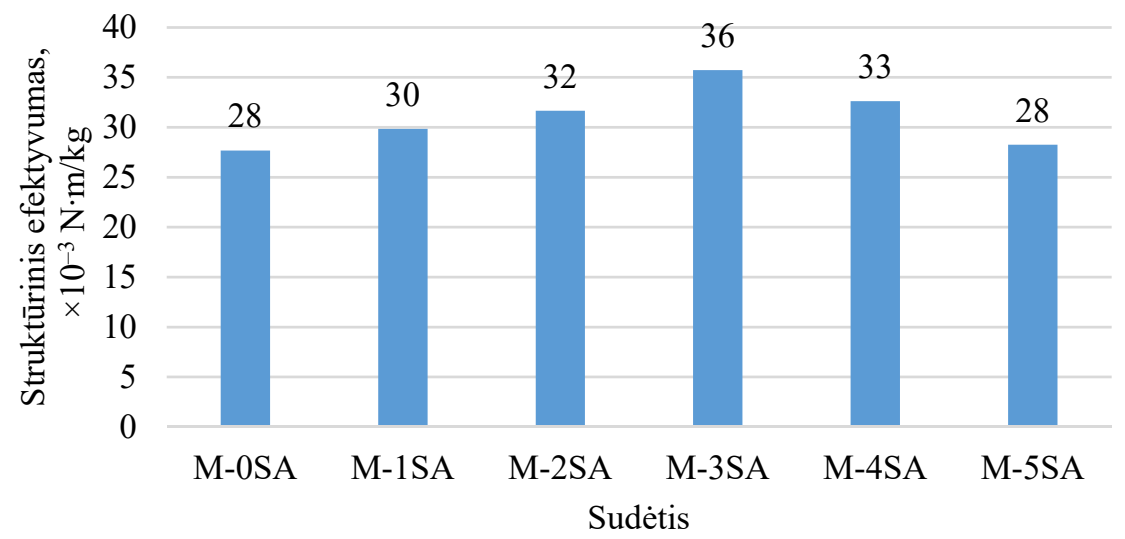

3.42 pav. Daugiasienių anglies nano vamzdelių kiekio poveikis bandinių su plastifikuojančių betono įmaišų mišiniu ir orą įtraukančia įmaiša struktūrinio efektyvumo rodikliui

Fig. 3.42. Structural efficiency of cement stone with plasticizers blend and airentraining, depending on the amount of multi-walled carbon nano tubes 
Matome, kad, didinant MWCNTs kiekį bandiniuose, jų struktūrinio efektyvumo rodiklis auga iki tam tikros ribos (3.42 pav.), tačiau, idejjus daugiau MWCNTs, struktūrinis efektyvumas pradeda mažèti ir pasiekia kontrolinio bandinio be MWCNTs vertes.

Idejjus MWCNTs nuo 0,00005 iki 0,005 proc., struktūrinis efektyvumas, palyginti su kontroliniu bandiniu, padideja 8,14 ir net $29 \%$ iki $36 \times 10^{-3} \mathrm{Nm} / \mathrm{kg}$ vertès. Toliau didinant MWCNTs kiekị, struktūrinis efektyvumas pradeda mažèti ir su maksimaliu, t. y. 0,5\%, kiekiu yra lygus kontrolinio bandinio struktūriniam efektyvumui. Šie skaičiavimai rodo, kad struktūrinis efektyvumas mažèja, kai MWCNTs priedas sudètyse viršija $0,05 \%$ kiekị. Šiuos duomenis patvirtina kitų autorių tyrimai (Luo et al., 2017).

\subsubsection{Cementinès matricos struktūros formavimosi tyrimai}

Atlikus UIG bandymus paaiškejjo, kad, priklausomai nuo įmaišų ir priedų, bandinių struktūros sutankèjimas ir struktūros susidarymas kietejjant vyksta skirtingai (3.43 pav.) (Chotard et al., 2001).

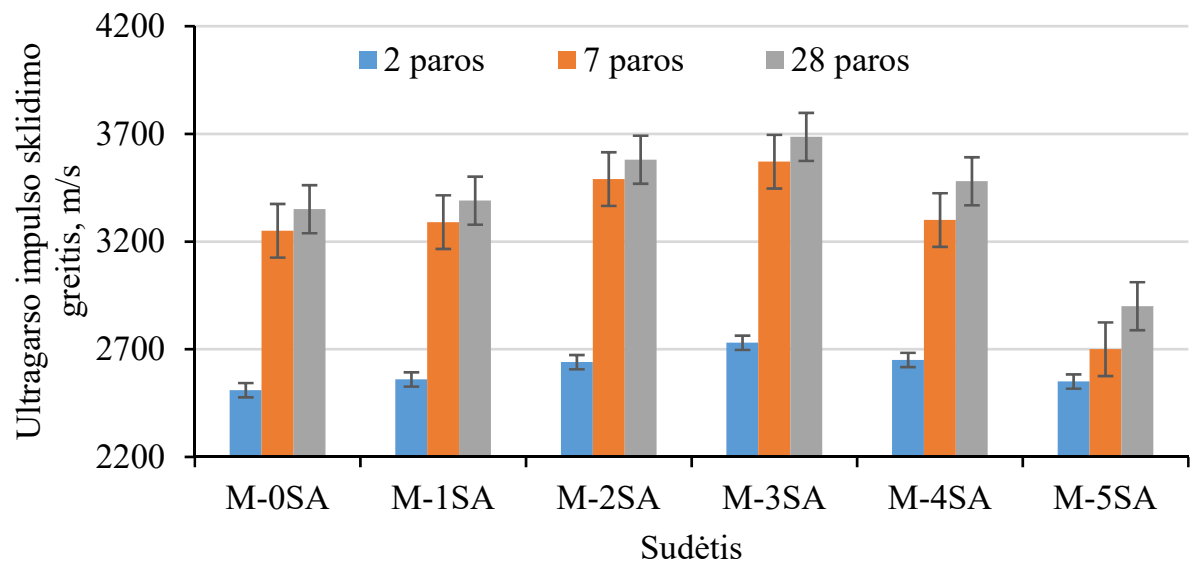

3.43 pav. Daugiasienių anglies nano vamzdelių kiekio poveikis bandinių su plastifikuojančių betono įmaišų mišiniu ir orą įtraukančia įmaiša ultragarso impulso sklidimo greičiui

Fig. 3.43. Ultrasound pulse velocity of cement stone with plasticizers blend and air entraining, depending on the amount of multi-walled carbon nano tubes

Po 2 paru kietejjimo UIG vertès bandiniuose kinta $2510-2730 \mathrm{~m} / \mathrm{s}$. Didžiausios UIG vertès fiksuojamos M-3SA bandinyje. Ženklus UIG verčių padidejjimas bandiniuose vyksta po 7 parų kietėjimo. Lyginant su rezultatais po 2 parų kietėjimo, UIG vertès bandiniuose padidèjo nuo 9,4 iki 35,1\%. Skirtingi MWCNTs 
kiekiai skirtingai veikia struktūros susidarymą. Didinant MWCNTs kiekị nuo $0,00005 \%$ iki $0,005 \%$ (M-1SA-M-3SA), bandinių UIG vertès didejja nuo 1,2 iki $9,8 \%$, lyginant su kontroliniu M-0SA bandiniu. Toks bandinių su mažesniais MWCNTs kiekiais UIG didejjimas gali būti dèl to, kad MWCNTs galimai užpildo poras tarp portlandcemenčio hidratacijos produktų (Siddique \& Mehta, 2014). Bandinių su didesniu MWCNTs kiekiu (0,05\% ir 0,5\%) UIG vertè pasieké 3480 ir $2900 \mathrm{~m} / \mathrm{s}$ reikšmes, arba 3,7 \% padidèjimą ir 13,5 \% sumažejimą, palyginti su kontroliniu M-0SA bandiniu.

Po 28 parų kietejjimo UIG vertès bandiniuose padidèjo nedaug, apytiksliai nuo 3 iki 7 \%, lyginant su bandinių, kietejusių 7 paras, UIG vertemis. Lyginant su kontroliniu M-0SA bandiniu, MWCNTs kiekio padidejimas nuo 0,00005 \% iki $0,005 \%$ padidina UIG vertes bandiniuose nuo $3390 \mathrm{iki} 3686 \mathrm{~m} / \mathrm{s}$.

Galima apibendrinti, kad UIG tyrimai iš esmès koreliuoja su gniuždymo stiprio bandymų rezultatais.

\subsection{Lengvojo kompozito tyrimai}

Paskutiniu etapu buvo formuojami ir tyrinejjami kompozitai. Kompozicinès medžiagos rišamoji medžiaga yra portlandcementis CEM I 42,5R, sunkusis užpildas maltas smèlis, lengvieji užpildai PPT ir PPN atliekos. Kompozito cementinès matricos savybėms gerinti panaudoti MWCNTs priedas, SP mišinys, orą įtraukianti įmaiša ir metakaolinas.

\subsubsection{Kompozito makrostruktūros ir mikrostruktūros tyrimai}

Siekiant paaiškinti kompozicinès medžiagos fizikinių ir mechaninių savybių rezultatus, buvo atlikti kompozitų bandinių K1C, K3C ir K5C, kuriuose PPT/PPN santykis buvo $0 / 4,2 / 2$ ir 4/0, makrostruktūros ir mikrostruktūros tyrimai.

Bandinių makrostruktūros tyrimai parodè, kad kompozito bandiniuose, esant skirtingam PPT/PPN santykiui, cementinès matricos storis tarp užpildo dalelių skiriasi. Kompozito bandinio, kuriame kaip užpildas yra tik PPN užpildo dalelès (PPT/PPN santykis 0/4), cementinès matricos storis tarp PPN dalelių yra mažiausias (3.44 pav. a) ir siekia $250 \mu \mathrm{m}$.

Kompozito, kuriame kaip užpildas yra tik PPT užpildo dalelès, cementinès matricos storis tarp užpildo dalelių yra didžiausias ir siekia 500-1500 $\mu \mathrm{m}$, tačiau taip pat pastebetos ir cementineje matricoje susidariusios stambios poros (3.44 pav. c) dèl didesnio kiekio neužpildytų tuštumų tarp lengvųjų užpildų. Tai rodo, kad naudojant tik PPT, cementinè matrica dẻl mažesnio PPT paviršiaus negu PPN sudaro labai storus matricos sluoksnius, kurie nesuteikia bandiniams didesnio stiprio. Kompozito bandinyje su PPT/PPN santykiu 2/2 cementinès matricos 
storis tarp užpildo dalelių sudaro $125-200 \mu \mathrm{m}$ (3.44 pav. b), o tai teigiamai gali paveikti kompozito tankị ir mechanines savybes.

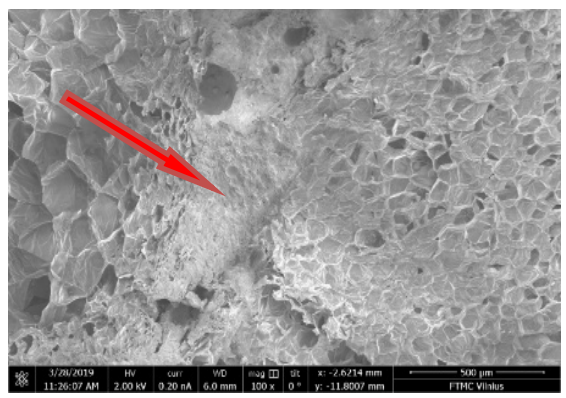

a)

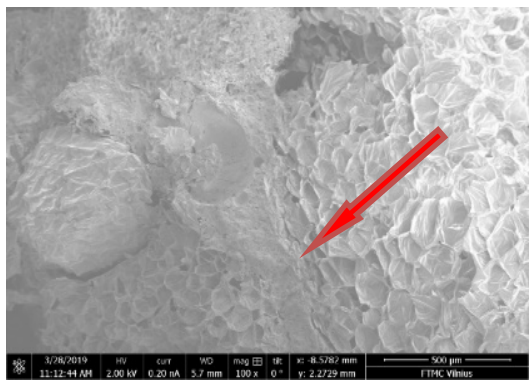

b)

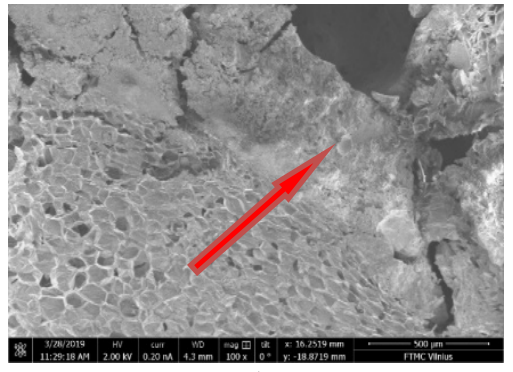

c)

3.44 pav. Kompozitų K1C, K3C ir K5C makrostruktūra (didinimas $-\times 100$ ):

a) trupintos/frezuotos $0 / 4$; b) trupintos/frezuotos $2 / 2$; c) trupintos/frezuotos $4 / 0$

Fig. 3.44. Macrostructure of K1C, K3C ir K5C composites (magnification $-\times 100$ ):

a) crushed $/$ milled $0 / 4$; b) crushed/milled $2 / 2 ;$ c) crushed $/$ milled $4 / 0$

Mikrostruktūros tyrimams buvo parinktas K3C bandinys su vienodu PPT ir PPN kiekiu. Matome, kad sąlyčio zonoje (3.45 pav. a) cementinè matrica pilnai užpildo visas PP dalelès ertmes. Taip pat galima pastebèti, kad tarpuose tarp dviejų stambesnių PP dalelių ( 3.45 pav. $b$ ir $\mathrm{b}^{1}$ ) smulkesnès PPN dalelès išsidèsto tarp MWCNTs plaušelių ir cemento hidratacijos produktų, sudarydamos unikalią tinklinę struktūrą, ir gerai užpildo tarpus tarp stambesnių dalelių. Porose, esančiose cementinejje matricoje, stebimas gausus kiekis MWCNTs, susipynusiu su cemento hidratacijos produktais (3.45 pav. c). Kaip matome (3.45 pav. d), sąlytis tarp MWCNTs plaušelių ir cementinès matricos yra geras, nes cementinè matrica maksimaliai užpildo PPN dalelių ertmes, plaušeliai apaugę hidratacijos produktais. 


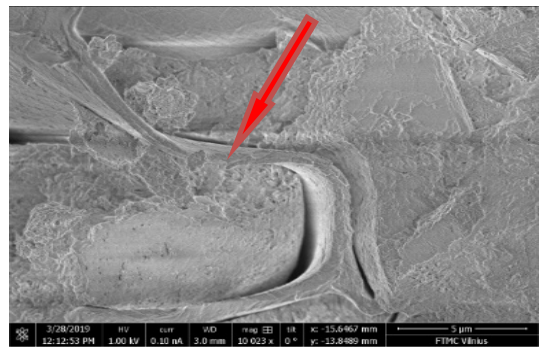

a)

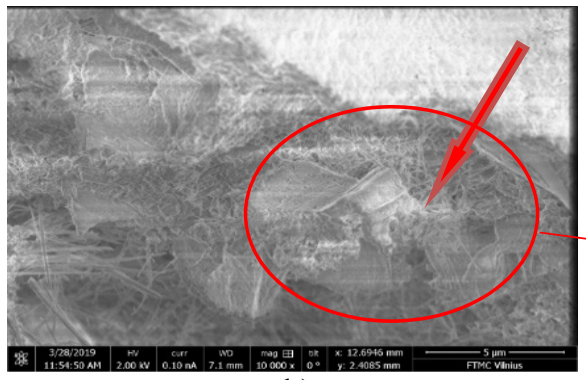

b)

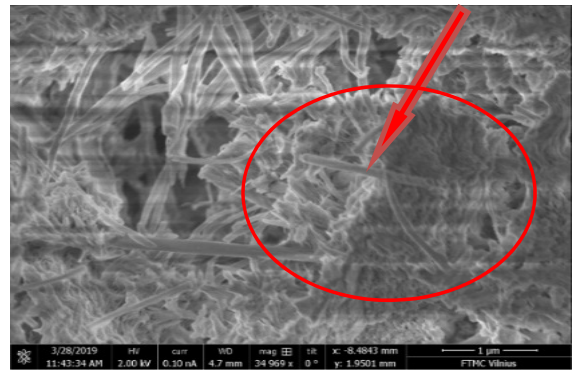

c)

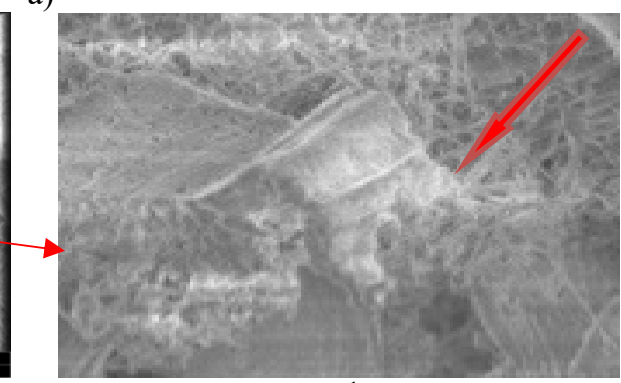

$\left.\mathrm{b}^{1}\right)$

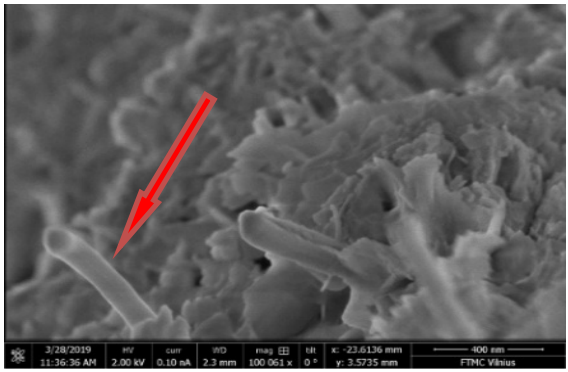

d)

3.45 pav. Kompozito K3C mikrostruktūra: a) trupintos atliekos ir cemento kontaktas (didinimas $\times 10000$ ); b) (didinimas $-\times 10000)$ ir $\left.\mathrm{b}^{1}\right)$ frezuotų atliekų dalelès tarp daugiasienių anglies nano plaušelių; c) daugiasieniai anglies nano vamzdeliai cemento matricos poroje (didinimas $-\times 35$

$000)$; d) daugiasienių anglies nano vamzdelių sąveika su cemento hidratacijos produktais (didinimas $-\times 100000$ )

Fig. 3.45. Microstructure of $\mathrm{K} 3 \mathrm{C}$ composite: a) crushed waste and cement contact (magnification $-\times 10000$ ); b) (magnification $-\times 10000$ ) and $b^{1}$ ) milled waste particles between multi-walled carbon nano tubes; c) multi-walled carbon nano tubes in the cement pore (magnification $-\times 35000$ ); d) interaction of multi-walled carbon nano tubes with cement hydration products (magnification $-\times 100000$ )

Kiti tyrèjai (Šeputytè-Jucikè, 2016) nustatė, kad sąlyčio zonos tarp PP dalelių ir cemento tešlos gerai susijungusios, neturi tuštymių ir supleišèjimų. Tyrèjas 
Kligys (2009) nustate, kad kompozicinių medžiagų bandiniuose yra glaudus intarpų ir matricos sąlytis.

\subsubsection{Kompozito tankis}

Projektuojant statinius privaloma atsižvelgti ị medžiagos tankį, nes vertinamos leidžiamosios apkrovos ị kitas konstrukcijas, o tai lemia medžiagų naudojimo galimybes ir sritis.

Mažejjant PPN daliai užpilde, t. y. kintant PPT/PPN santykiui tokia seka $4 / 0 \rightarrow 3 / 1 \rightarrow 2 / 2 \rightarrow 0 / 4,28$ paras kietejjusių bandinių tankis (3.46 pav.) sumažèjo maždaug 2,5 karto (nuo 830 iki $320 \mathrm{~kg} / \mathrm{m}^{3}$ ), kai sudètyse nenaudotas MWCNTs priedas ir nuo $780 \mathrm{iki} 260 \mathrm{~kg} / \mathrm{m}^{3}$, kai sudètyse buvo panaudotas MWCNTs priedas.

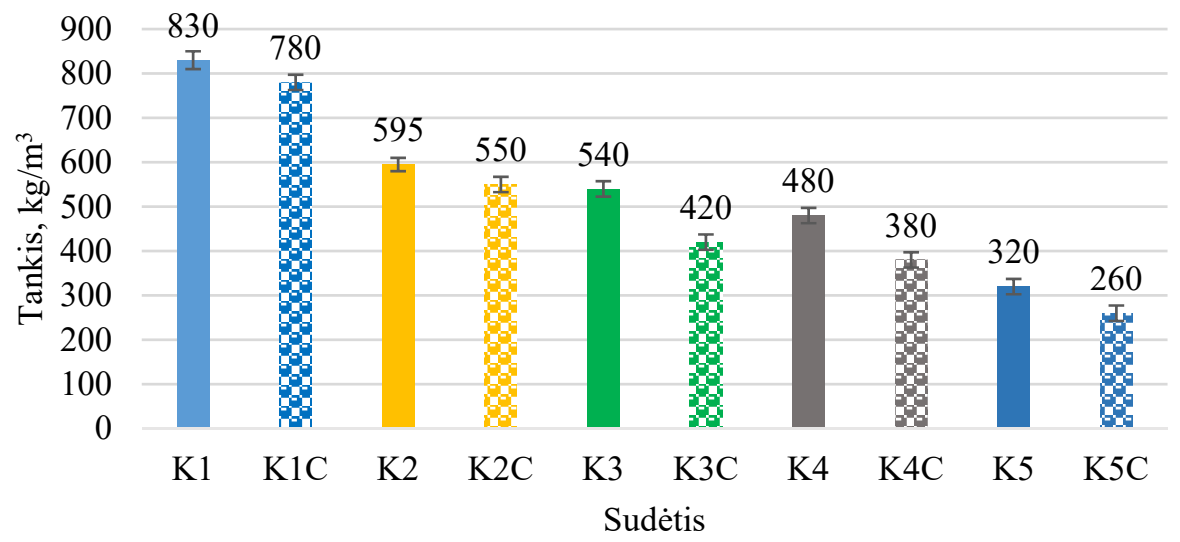

3.46 pav. Kompozito bandinių tankis

Fig. 3.46. The density of the lightweight composite

Matome, kad ị sudètis ịdètas MWCNTs priedas dar šiek tiek pakeitè bandinių struktūrą ir sumažino tankị 6, 8, 22, 21 ir $19 \%$ atitinkamose K1C-K5C sudęčių bandiniuose. Labiausiai tankis sumažejo K3C ir K4C sudéčių bandiniuose, kuriuose, mūsų manymu, susidare daugiausia tuštumų ir buvo įtrauktas oras maišant. Kompozitų mikrostruktūros ir toliau atlikti UIG tyrimai patvirtina bandinių tankio tyrimus.

\subsubsection{Kompozito gniuždymo stipris}

Gniuždymo stipris dažniausiai lemia medžiagos naudojimo sritis ir galimybes. Mokslininkai nuolat bando sukurti kuo mažesnio tankio, kuo didesnio gniuždymo 
stiprio ir geresnių termoizoliacinių savybių statybines medžiagas. Kompozicinių medžiagu gniuždymo stipris tiesiogiai priklauso nuo cemento akmens gniuždymo stiprio bei naudojamų lengvujų užpildų stiprio ir užpildo agregatų adhezijos su cemento akmeniu. Kuo didesnis lengvuju užpildų kiekis bandinyje, tuo mažesnis viso kompozito stipris. Tą patvirtino atlikti gniuždymo stiprio bandymai.

Analizuojant bandinių be MWCNTs priedo gniuždymo stiprio rezultatus, matyti, kad didžiausią stiprio vertę po 28 paru kietejimo turejjo bandinys K1, kurio sudetyje buvo tik PPN atliekos, t. y. PPT/PPN santykis buvo 0/4. Śios sudeties bandinių gniuždymo stipris siekia 6,5 MPa (3.47 pav.). Keičiant PPT/PPN santyki i 1/3, t. y. didinant PPT kiekị sudètyje, bandinių gniuždymo stipris sumažèjo iki 4,5 MPa. Kai PPT/PPN santykis buvo 2/2, bandinių gniuždymo stipris sumažèjo iki 2,4 MPa, kai santykis buvo 3/1, bandinių gniuždymo stipris mažèjo iki $1,3 \mathrm{MPa}$, o kai PPT/PPN santykis tapo 4/0, bandinių gniuždymo stipris buvo mažiausias ir siekė tik 0,7 MPa. Procentine išraiška bandinių stiprio vertès, palyginus su bandinių, kuriuose PPT/PPN santykis buvo 0/4, mažèjo 30, 63, 80 ir $89 \%$. Tai atitinka teorines hipotezes, kad, įdejus mažo stiprio užpildo ir esant silpnai agregatų adhezijai, viso kompozito stipris mažeja. Tą pačią tendenciją pastebi autoriai (Koksal et al., 2020), nustatę, kad, keičiant vermikulito ir PP tūrio santykị nuo 3 iki 7, tankis dèl didelio poringumo mažèja tris kartus, o bandinių gniuždymo stipris mažeja iki 10 kartų. Gregorova et al. (2017) savo tyrime nurodo, kad, kuriant mažo tankio kompozitą $\left(250-375 \mathrm{~kg} / \mathrm{m}^{3}\right)$ iš $\mathrm{PP}$ ir polietileno atliekų vienodomis dalimis, bandinių gniuždymo stipris tesiekia $0,1-0,15 \mathrm{MPa}$.

Galimai mūsų atveju, didinant PPT dalị, cemento matricos sluoksnelių storis aplinkui PPT daleles buvo nepakankamas didesnèms gniuždymo stiprio vertèms užtikrinti.

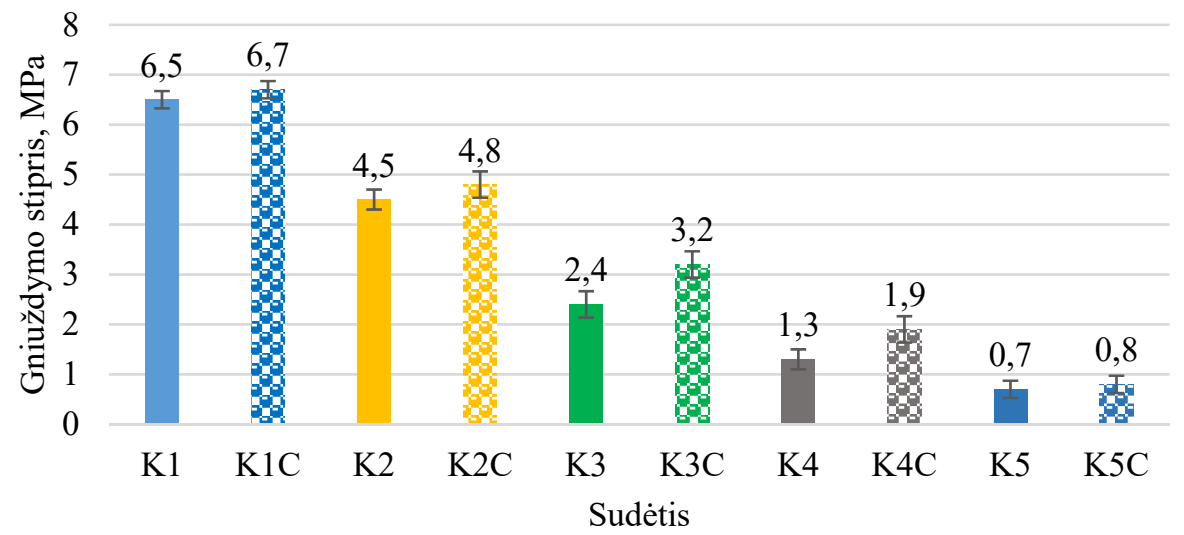

3.47 pav. Kompozito bandinių gniuždymo stipris

Fig. 3.47. Compressive strength of the lightweight composite 
Kaip parodė atlikta literatūros apžvalga, nanopriedų naudojimas, siekiant pagerinti kompozitų mechanines savybes, gali duoti teigiamų rezultatų (Fathi et al., 2017), kai gniuždymo stipris padidejjo maždaug 15-25\%.

$0,005 \%$ MWCNTs kiekis, panaudotas kompozito sudetyje, labai gerina kompozito gniuždymo stiprio vertes. PPT/PPN santykiui esant $0 / 4$, bandinių gniuždymo stipris padidejo $3 \%$, lyginant su analogiškos sudèties bandiniais be MWCNTs priedo. Kai PPT/PPN santykis pakito iki 1/3, bandinių gniuždymo stipris padidejo $7 \%$. Didžiausias gniuždymo stiprio verčių pokytis įvyko PPT/PPN santykiui esant $2 / 2$ ir $2 / 3$. Šių sudèčių bandinių gniuždymo stiprio vertès atitinkamai pakilo 33 ir $46 \%$. Esant PPT/PPN santykiui 4/0, bandinių gniuždymo stipris padidejjo $14 \%$.

Galima pastebėti, kad bandiniuose su PPT/PPN santykiu 2/2 ir 3/1 susidaro ypatinga oro tuštumų - MWCNTs, pasiskirsčiusių tarp užpildų, struktūra (3.45 pav. b ir c), užtikrinanti unikalias bandinių savybes.

\subsubsection{Kompozito struktūrinio efektyvumo rodiklis}

Geresniam kompozito apibūdinimui ir optimalios sudèties parinkimui buvo atlikti struktūrinio efektyvumo rodiklio skaičiavimai. Palyginimui buvo apskaičiuotas struktūrinio efektyvumo rodiklis kompozituose be MWCNTs priedo ir kompozituose su MWCNTs priedu.

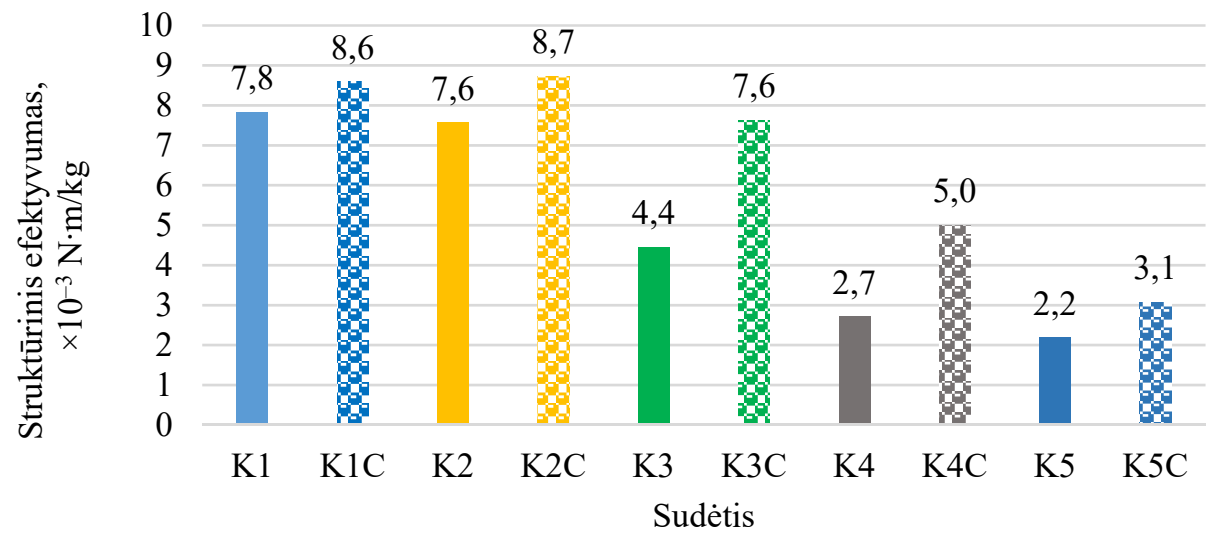

3.48 pav. Kompozito bandinių struktūrinio efektyvumo rodiklis

Fig. 3.48. Structural efficiency values of the lightweight composite 
Matyti, kad kompozito sudètyse keičiant PPT/PPN santykị nuo 0/4 iki 4/0, struktūinio efektyvumo rodiklis mažèja nuo $7,83 \times 10^{-3} \mathrm{~N} \cdot \mathrm{m} / \mathrm{kg}$ iki $2,18 \times 10^{-3} \mathrm{~N} \cdot \mathrm{m} / \mathrm{kg}$ vertès (3.48 pav.). Akivaizdžiai struktūrinio efektyvumo rodiklis sumažèja, kai PPT/PPN santykis pasiekia $2 / 2$ ir 3/1 (K3C ir K4C), kai struktūrinio efektyvumo rodiklis sumažeja iki $4,44 \times 10^{-3} \mathrm{~N} \cdot \mathrm{m} / \mathrm{kg}$ ir $2,7 \times 10^{-3} \mathrm{~N} \cdot \mathrm{m} / \mathrm{kg}$ vertès.

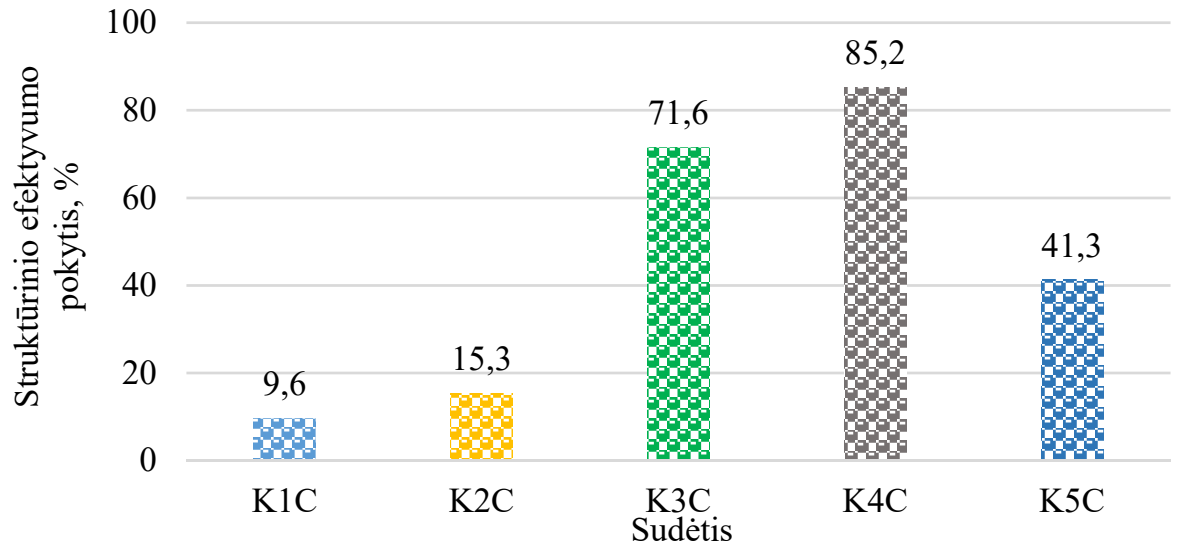

3.49 pav. Kompozito bandinių struktūrinio efektyvumo rodiklio pokyčio procentine išraiška

Fig. 3.49. Structural efficiency percentage variation of the lightweight composite

Kompozito bandiniuose su MWCNTs bandinių struktūrinio efektyvumo rodiklis yra pastebimai didesnis nei kompozituose be MWCNTs priedo. Šio skirtumo procentinè išraiška pateikta 3.49 paveiksle. Ypač tai pastebima sudetyse, kuriose PPT/PPN santykis siekia $2 / 2$ ir 3/1. Tai rodo, kad, didinant PPT dali kompozito sudètyje, modifikuota cementinè matrica efektyviau sąveikauja su užpildu ir užtikrina aukštesnes fizikines ir mechanines savybes. Kai kompozito sudètyje vyrauja tik PPT, struktūrinis efektyvumas mažèja. Apibendrinant galima padaryti išvadą, kad optimalios kompozito sudètys yra K3C ir K4C.

\subsubsection{Kompozito ultragarso impulso sklidimo greičio tyrimai}

Sukietejjusių bandinių tankio ir stiprio rezultatams paaiškinti buvo atlikti bandinių ultragarso impulsų sklidimo greičio (UIG) matavimai. UIG matavimai (3.50 pav.) rodo, kad po 2, 7 ir 28 parų kietėjimo visų sudèčių bandinių UIG vertès tolygiai didèjo.

Didžiausią UIG reikšmę ( $2620 \mathrm{~m} / \mathrm{s})$ po 2 parų turèjo didžiausio tankio bandiniai tik su PPN užpildu, kuriuose PPT/PPN santykis buvo 0/4. I sudètị dedant PPT užpildo, t. y. keičiant PPT/PPN santykị iki 4/0, UIG vertės bandiniuose nuosekliai 
mažèjo. K5 sudèties bandiniuose, kuriuose buvo tik PPT užpildas (PPT/PPN santykis 4/0) ir atitinkamai mažiausias tankis, UIG reikšmè po 2 parų buvo mažiausia $1010 \mathrm{~m} / \mathrm{s}$.

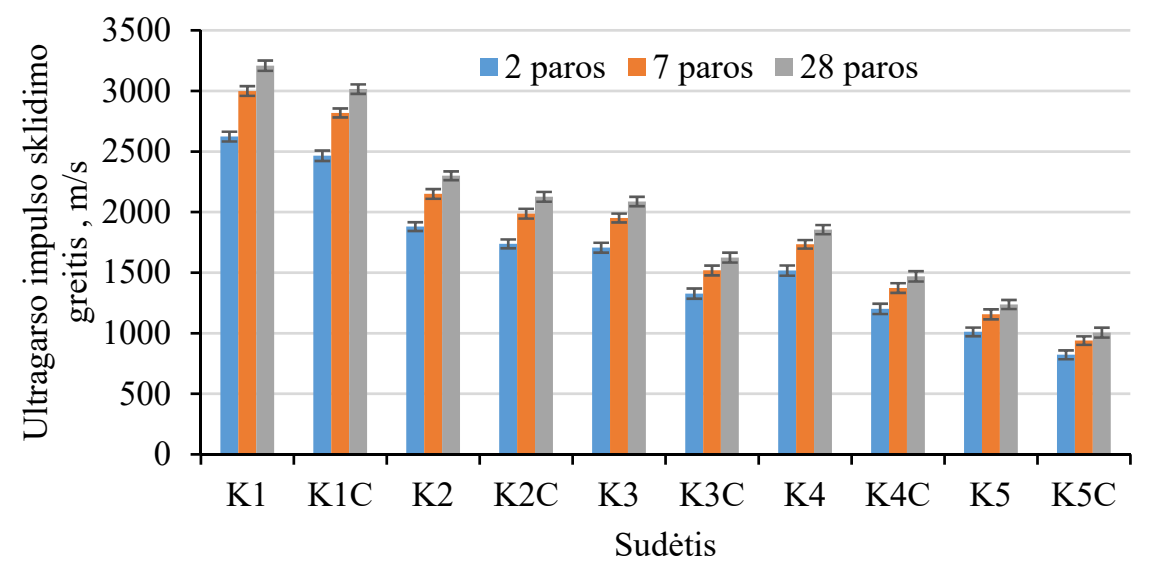

3.50 pav. Kompozito bandinių ultragarso impulso sklidimo greitis Fig. 3.50. Ultrasound pulse velocity of the lightweight composite

Tai gali paaiškinti autorių atlikti tyrimai, įrodantys, kad PP sukuria ypatingą oro tuštumų struktūrą bandiniuose. Kompozito sudètyje didejjant PP, susidaro daugiau smulkesnių nei $10^{-4}-10^{-6} \mu \mathrm{m}^{3}$ dydžio oro tuštumų ir porų (Dixit et al., 2019). Mūsų atveju K5 sudeties bandinių tankis dèl oro tuštumų ir PPT išsidèstymo kompozito struktūroje yra mažiausias, todèl ir UIG vertès mažiausios. Po 7 parų kietèjimo UIG visų sudèčių bandiniuose didèjo apytiksliai $12-12,5 \%$, o po 28 parų kietejjimo - 18,0-18,3\%, palyginti su UIG vertėmis po 2 parų kietėjimo.

I sudètis įdėjus MWCNTs priedą, galima pastebèti, kad bandinių UIG vertès mažèja, palyginus su analogiškomis sudètimis be MWCNTs priedo. UIG vertès po 2 parų kietejimo bandiniuose $\mathrm{K} 1 \mathrm{C}$ ir $\mathrm{K} 2 \mathrm{C}$ yra 6,4-6,6 \% žemesnès nei $\mathrm{K} 1$ ir K2 bandiniuose. Dar didesnis skirtumas stebimas K3C, K4C ir K5C bandiniuose $-28,6 \%, 26,3 \%$ ir 22,9\%. Po 7 parų kietėjimo visų sudéčių UIG vertès padidejo $12-13 \%$. Tačiau lyginant su analogiškomis sudètimis be MWCNTs priedo, UIG vertės bandiniuose su MWCNTs priedu išlieka mažesnès. K1C ir K2C bandiniuose UIG vertès yra 6,4 ir 8,2 \% žemesnès nei K1 ir K2 bandiniuose, o K3C, K4C ir K5C bandiniuose UIG vertès yra 28,5 \%, 18,1 \% ir 23,1 \% žemesnès nei K3, K4 ir K5 bandiniuose. Po 28 parų kietėjimo, UIG visų sudèčių bandiniuose didejo $18-18,5 \%$, lyginant su UIG vertemis po 2 parų kietejimo. K1C ir K2C bandiniuose UIG vertès yra 6,2 ir 8,1 \% žemesnès nei $\mathrm{K} 1$ ir $\mathrm{K} 2$ bandiniuose po atitinkamo 28 parų laikotarpio, o $\mathrm{K} 3 \mathrm{C}, \mathrm{K} 4 \mathrm{C}$ ir $\mathrm{K} 5 \mathrm{C}$ bandiniuose UIG vertès 
yra $28,2 \%, 26,1 \%$ ir 22,7 \% žemesnès nei K3, K4 ir K5 bandiniuose. Galima daryti išvadą, kad, keičiant PPT/PPN santykị, galima didinti arba mažinti porų ir tuštumų kiekị bandinių struktūroje. Naudojant sudėtyje MWCNTs priedą, bandinių struktūra pasižymi dar didesniu tuštymètumu ir poringumu, todèl UIG vertès tokiuose bandiniuose yra žemesnès. Be to, galima pastebėti, kad PPT/PPN santykis $2 / 2$ ir $2 / 3$ ir $0 / 4$ bandiniuose labiausiai prisideda prie bandinių poringumo ir tuštymètumo didinimo. Sąveikaujant su MWCNTs priedu, tokių bandinių struktūroje porų ir tuštymių kiekis didèja, todèl UIG vertès jose $28,2-22,7$ \% mažesnès nei bandiniuose, kuriuose PPT/PPN santykis yra $0 / 4$ ir 1/3.

\subsubsection{Kompozito šilumos laidumo koeficientas}

Lengvosios kompozicinès medžiagos šilumos laidumo koeficiento vertès pateiktos 3.51 paveiksle. Kaip ir tikètasi, didžiausią šilumos laidumo koeficiento vertę turejjo didžiausio tankio bandinys K1 su didžiausiu PPN atliekų kiekiu ir siekè $0,233 \mathrm{~W} /(\mathrm{m} \cdot \mathrm{K})$ vertę. Bandinyje didinant PPT kiekį, šilumos laidumo koeficiento vertė nuolat mažėjo iki $0,1542,0,1539$, ir 0,1164 , o bandinyje su didžiausiu PPT kiekiu - iki 0,0971 W/(m·K) vertės. Tokias pačias tendencijas aprašo autoriai, tyrinèję kompozitus su PP be MWCNTs priedo (Šeputytė-Jucikè, 2016; Kligys, 2009).

Jų darbuose nustatyta, kad, didinant lengvojo užpildo kiekị, šilumos laidumo koeficiento vertès mažèja, tačiau bandinių mechaninès savybès yra mažesnès nei mūsų atveju. Tai ypač išryškejja bandiniuose su mažiausiais tankiais (žemesniais nei $300 \mathrm{~kg} / \mathrm{m}^{3}$ ). Kligys (2009) darbe nustatè, kad kompozito tankiui esant $250 \mathrm{~kg} / \mathrm{m}^{3}$, šilumos laidumo koeficiento verte siekia $0,073 \mathrm{~W} /(\mathrm{m} \cdot \mathrm{K})$, o gniuždymo stipris - 0,2 MPa. Kitame darbe (Šeputytè-Jucikè, 2016) buvo nustatyta, $\mathrm{kad}$, esant kompozito tankiui $247 \mathrm{~kg} / \mathrm{m}^{3}$, šilumos laidumo koeficiento verte yra $0,073 \mathrm{~W} /(\mathrm{m} \cdot \mathrm{K})$, o gniuždymo stipris - 0,38 MPa. Mūsų atveju kompozito tankiui esant $260 \mathrm{~kg} / \mathrm{m}^{3}$, šilumos laidumo koeficiento vertè yra didesnè ir siekia $0,0931 \mathrm{~W} /(\mathrm{m} \cdot \mathrm{K})$, o gniuždymo stipris $-0,8 \mathrm{MPa}$.

Dixit et al. (2019) nurodo, kad didesnis porų kiekis bandinyje užtikrina mažesni šilumos laidumą dèl lètesnio šilumos perdavimo. I bandinius įdètas MWCNTs smarkiai pagerino bandinių šilumos laidumo savybes. Galimai ne tik MWCNTs struktūra (Xiao, 2013; Xu \& Li, 2014), bet ir MWCNTs sąveika su OIP, dèl kurios didèja bandinių poringumas, gerina bandinių šilumos laidumo savybes. Šilumos laidumo koeficientas, esant $\mathrm{K} 1 \mathrm{C}-\mathrm{K} 5 \mathrm{C}$, atitinkamai sumažèjo $18 \%, 9 \%, 25 \%, 11 \%$ ir $4 \%$, lyginant su analogiškomis sudetimis be MWCNTs, K1-K5. 


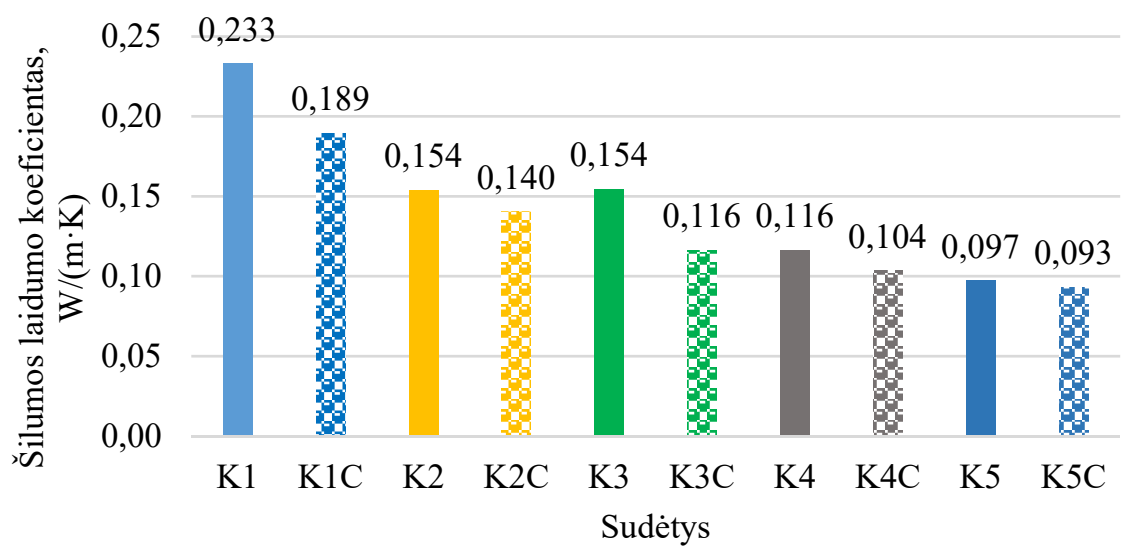

3.51 pav. Kompozito šilumos laidumo koeficientas

Fig. 3.51. Thermal conductivity of composite

Šilumos laidumo koeficiento vertès, palyginus su termoizoliacinėmis polistireninio putplasčio ar akmens vatos vertemis, yra 2-5 kartus didesnès, tačiau gniuždymo stiprio vertès yra 5-33 kartus didesnès už polistireninio putplasčio ir 13-110 kartų už akmens vatos, o tai labai padidina kompozicinès medžiagos pritaikymo galimybes.

\subsubsection{Kompozito kapiliarinès sugerties koeficientas}

Statybinès medžiagos eksploatacijos metu gali būti veikiamos drègmès. Išorèje medžiagas veikia krituliai sniegas ir lietus. Taip pat medžiagos gali būti laikinai paveiktos gausios drègmès vandens kiekio, pavyzdžiui, užpylimo atveju. Medžiagos taip pat gali būti veikiamos netiesioginès nuolatinès drègmès, pvz., kylančios iš žemės, kurios kapiliarais ịsigeria ị medžiagą ir blogina jos savybes. Taip pat tai ypač aktualu medžiagas naudojant kaip hidrofobines atitvaras.

3.52 paveiksle pateikti duomenys rodo, kad, mažèjant bandinių tankiui ir didejjant PPT daliai sudètyje, bandinių kapiliarinès sugerties koeficientas didèja. Galimai tai vyksta ir dèl didesnio kiekio neužpildytų tuštumų tarp lengvųjų užpildų su didesniu PPT kiekiu. 


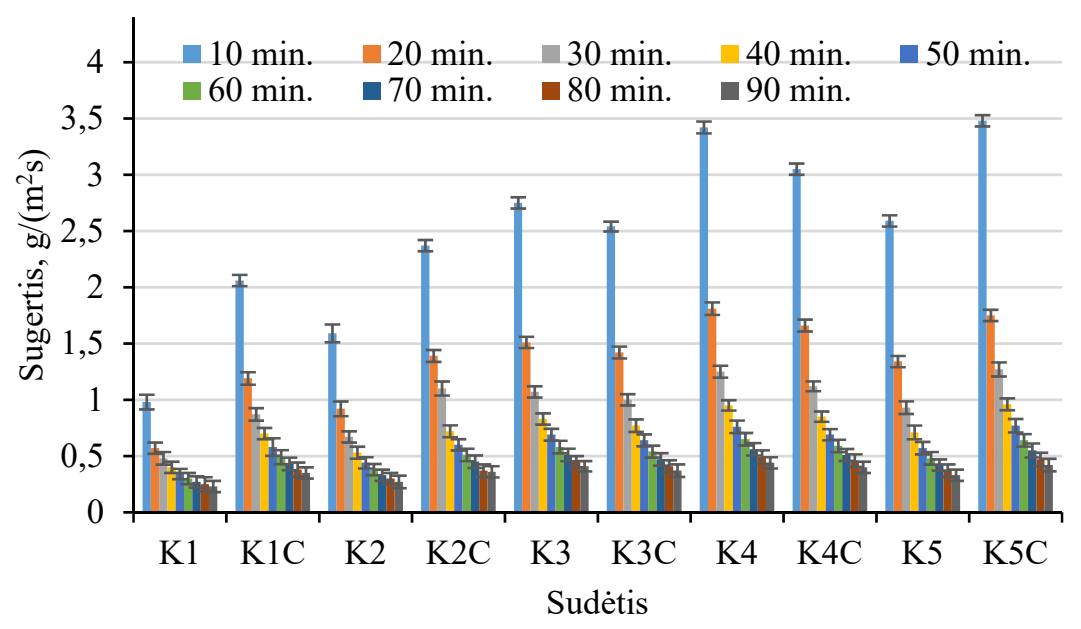

3.52 pav. Kompozito bandinių kapiliarinès vandens sugerties koeficientas

Fig. 3.52. Water absorption of composites due to capillary action

Tyrimai, atlikti per pirmąsias $30 \mathrm{~min}$., rodo tendenciją, kad bandiniuose su MWCNTs priedu kapiliarinès sugerties koeficientas yra šiek tiek didesnis nei bandiniuose be MWCNTs priedo. Tačiau po 40-90 min. ši tendencija išlieka tik K1C ir $\mathrm{K} 2 \mathrm{C}$ bandiniuose. Taip pat galima pastebèti, kad visais atvejais būdingas staigus vandens sugerties intensyvumo mažejimas, kuris trunka 20-30 min. Vèliau sugerties procesas išlieka panašus visuose kompozituose - per likusias 90 min. sugerties intensyvumas sumažeja apie du kartus. Kitų autorių (Šeputytė-Jucikè, 2016; Kligys, 2009) darbuose gauti panašūs rezultatai.

Nors PPN vandens sugertis yra gerokai didesnè nei PPT, rezultatai byloja, kad didžiausios kapiliarinès sugerties koeficiento reikšmès yra bandiniuose su didesniu PPT kiekiu. Šių tyrimų duomenys rodo, kad vandens patekimas į bandinio struktūrą vyksta per cementinę matricą. Galimai storesni matricos sluoksniai (kaip matème makrostruktūros tyrimuose) ir matricos porètumas $\mathrm{K} 4-\mathrm{K} 5$ ir $\mathrm{K} 4 \mathrm{C}-\mathrm{K} 5 \mathrm{C}$ bandiniuose skatina vandenị greičiau patekti ị bandinį.

\subsubsection{Kompozito vandens garu pralaidumas}

Statyboje keliami labai aukšti reikalavimai A+ pastatų išorinėms atitvaroms. Norint atitikti šiuos reikalavimus, išorinèms atitvaroms naudojamos kelių tipų medžiagos, tačiau skirtingos medžiagos turi nevienodą vandens garų varžos faktorių $\mu$, kuris apibūdinamas kaip medžiagos savybė praleisti garus. $\mu$ parodo, kiek kartų tiriamos medžiagos drègminè varža yra didesnè už tokio pačio storio oro sluoksnio drègminę varžą, kuri lygi 1. Kad atitvaroje nesikauptų drègmè ir neatsirastų 
pelèsių, būtina parinkti medžiagas su panašiomis vandens garų pralaidumo savybėmis, šiuo atveju garai laisvai praeis ir nesikondensuos skirtingų medžiagų sujungimo vietose.

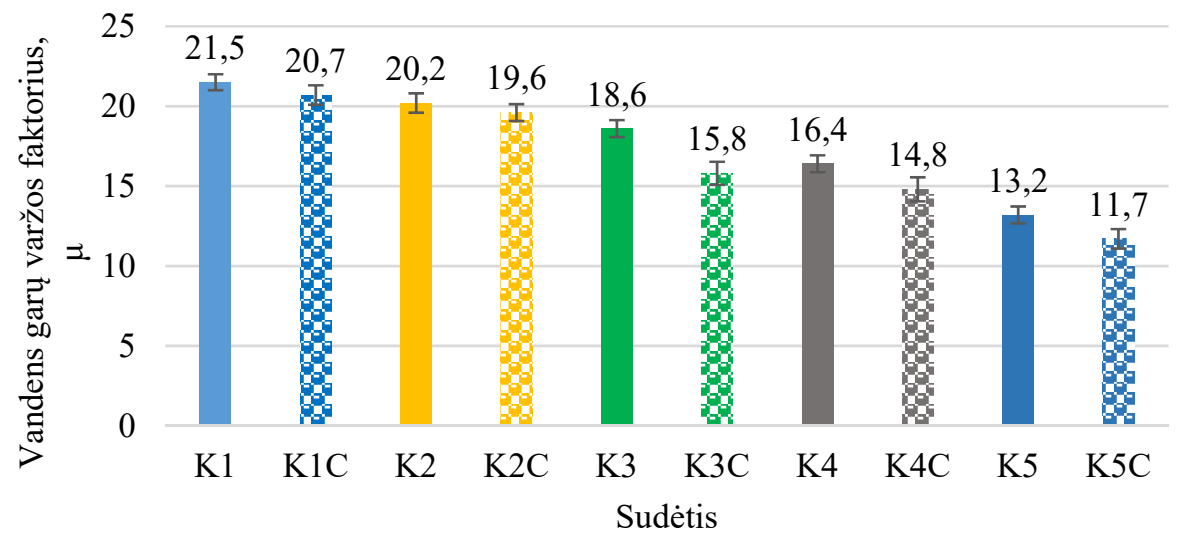

3.53 pav. Kompozito bandinių vandens garų varžos faktorius

Fig. 3.53. Water vapour resistance factor of composites

Nustatyta, kad kompozito bandiniuose ir mažinant PPN kieki, ir kartu didinant PPT kiekį, vandens garų varžos faktorius mažejja (3.53 pav.). Didžiausias vandens garų varžos faktorius pasiektas bandiniuose su maksimaliu PPN kiekiu 21,5. Esant PPT/PPN santykiui 1/3, kompozite vandens garų varžos faktorius sumažeja $6 \%$, esant PPT/PPN santykiui $2 / 2$, vandens garų varžos faktorius sumažeja $13 \%$, lyginant su kompozito sudètimi, kurioje PPT/PPN santykis 0/4. Kai PPT/PPN santykis kompozite yra 3/1, vandens garų varžos faktorius mažeja iki $24 \%$, o pasiekus santykị 4/0 koeficientas $\mu$ sumažèja iki $39 \%$.

I bandinius įdejjus MWCNTs priedo, vandens garų varžos faktorius $\mu$, palyginus su atitinkamo santykio bandiniais be MWCNTs, sumažèja atitinkamai $4 \%$, $3 \%, 15 \%, 10 \%$ ir $11 \%$.

\subsubsection{Kompozito džiūstamasis traukumas}

Džiūstamasis traukumas - taip pat svarbi medžiagos savybè, ị kurią privalo atsižvelgti projektuotojai, parinkdami medžiagas statybai. Skirtingomis eksploatacijos sąlygomis medžiagos gali plèstis arba trauktis. Kylant santykinei drègmei, medžiagos absorbuoja drègmę ir plečiasi, ir atvirkščiai, santykinei drėgmei mažèjant, drègmė pasišalina ir medžiaga pradeda trauktis. Ypač svarbu nustatyti ir žinoti šias savybes, gaminant labai tikslių matmenų dirbinius, kai dirbiniai mūrijami plonasluoksniais skiediniais. Šie parametrai padeda prognozuoti galimus įtrūkius 
eksploatacijos metu ir dar projekte numatyti temperatūrines siūles ar suderinti atitinkamas medžiagas.

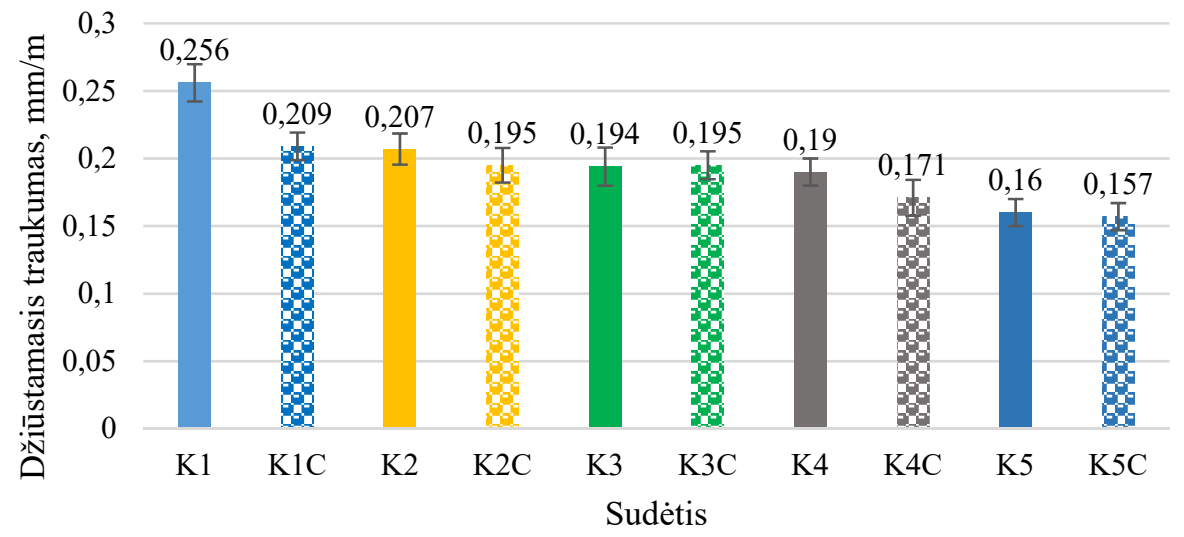

3.54 pav. Kompozito bandinių džiūstamasis traukumas

Fig. 3.54. Drying shrinkage of composite

Buvo nustatyta (3.54 pav.), kad esant PPT/PPN santykiui 0/4, 28 paras kietéjusių K1 bandinių džiūstamasis traukumas pasiekė $0,256 \mathrm{~mm} / \mathrm{m}$ vertę. Didinant PPT kieki, t. y. PPT/PPN santykiui esant $1 / 3, \mathrm{~K} 2$ bandinių džiūstamasis traukumas sumažejo $19 \%$ ir siekè $0,207 \mathrm{~mm} / \mathrm{m}$. Kai PPT ir PPN santykis bandiniuose yra vienodas, K3 bandinių džiūstamasis traukumas mažèja $24 \%$, lyginant su K1 bandiniu, o esant santykiui 3/1 ir 4/0, bandinių džiūstamasis traukumas mažèja $25 \%$ ir $37 \%$.

I šiuos bandinius įdèjus vienodą MWCNTs, t. y. 0,005\% kiekį, palyginus su bandiniais be MWCNTs, džiūstamasis traukumas dar sumažejo atitinkamai $18 \%$, $6 \%, 1 \%, 10 \%$ ir $2 \%$ atitinkamai. Apie teigiamą MWCNTs poveikị kompozitų džiūstamajam traukumui nurodo Radlinska et al., (2008). Kadangi MWCNTs užpildo įtrūkius ir poras, kaip rodo ir mūsų atlikti mikrostruktūros tyrimai, silpnèja kapiliariniai ir susitraukimo ịtempiai, taip neleisdami cemento akmeniui daugiau susitraukti. Didesnis MWCNTs poveikis bandinių džiūstamajam traukumui matomas, kai bandinių struktūroje vyrauja arba PPN, arba PPT. Galimai PPN atveju, kai cementinès matricos storis yra mažiausias, gali būti didesnè MWCNTs sąveika su PPN dalelių paviršiais, atliekant savotišką armavimo funkciją. Bandiniuose, kurių struktūroje vyrauja PPT, MWCNTs labiau pasireiškia cementinèje matricoje, kurios storis yra didžiausias ir dèl savo tiltelių sudarymo ir mikroporų užpildymo mažina džiūstamajị traukumą. 


\subsection{Trečiojo skyriaus išvados}

1. Nustatyta, kad tirpale su $0,017 \%$ daugiasieniu anglies nano vamzdelių kiekiu MWCNTs dispergavimas yra geresnis nei tirpaluose su minimaliu $0,00017 \%$ ir maksimaliu $1,7 \%$ MWCNTs kiekiu. Didinant daugiasienių anglies nano vamzdelių kiekị tirpale, tirpalų elektrinis laidumas didèja, o pH mažèja.

2. Nustatyta, kad $0,005-0,05 \%$ daugiasienių anglies nano vamzdelių kiekis mažina cemento tešlos klampą. Didžiausia klampa nustatyta cemento tešlose su 0,00005-0,0005 \% daugiasienių anglies nano vamzdelių kiekiu.

3. Nustatyta, kad daugiasieniai anglies nano vamzdeliai lètina cemento hidrataciją: didinant MWCNTs kiekị cemento tešlose, elektrinio laidumo ir $\mathrm{pH}$ vertès mažèja nuo $15,3 \mathrm{mS}$ iki $14,6 \mathrm{mS}$ ir nuo 12,9 iki 12,3, o rišimosi trukmè sulèteja du kartus. Egzoterminès reakcijos temperatūra mažèja $22 \%$, o maksimumo laikas ilgejja $150 \%$.

4. Nustatyta, kad 28 paras kietejusio cemento akmens ultragarso impulsų sklidimo greitis, gniuždymo ir lenkimo stipris dideja iki $4 \%, 7,4 \%$ ir $19,5 \%$, kai MWCNTs kiekis sudare 0,00005-0,005\%. Bandinių su $0,05 \%$ ir $0,5 \%$ MWCNTs kiekiais ultragarso impulsu sklidimo greitis, gniuždymo ir lenkimo stipris mažejo iki $0,7 \%, 7,4 \%$ ir $8,3 \%$.

5. Cemento tešlų su pavieniais SP ((lignosulfonatų SP (A), poliakrilatų SP (B) ir polikarboksilatų SP (C) pagrindu) tyrimai parode, kad didžiausios sklidumo vertės pasiektos bandiniuose, kai jų kiekis neviršija $0,2 \%$. SP mišinys, susidedantis iš dviejų tipų SP (poliakrilatų ir polikarboksilatų), sumažino klampą iki 1,5 karto, palyginti su cemento tešlomis su pavieniais SP.

6. Lyginant su kontroline tešla be SP, egzoterminès reakcijos maksimumo laikas cemento tešlų su SP mišiniu ir pavieniais SP (B) ir SP (C) pailgejo $12,5 \%, 20 \%$ ir 32,5\%, o tešloje su SP (A), priešingai, egzoterminès reakcijos temperatūros maksimumo laikas sutrumpejo $25 \%$, EXO maksimumo temperatūra sumažèjo $6{ }^{\circ} \mathrm{C}$. Didžiausią UIG vertę po $24 \mathrm{~h}$ kietèjimo pasiekè cemento tešla su SP mišiniu.

7. Rentgenografinè ir termografinè analizè rodo, kad po 28 parų kietèjimo kontrolinis bandinys ir bandiniai su pavieniais SP bei SP mišiniu turi panašią mineralinę sudètí, tačiau skiriasi hidratacijos produktų 
kiekiai. Bandinyje su SP mišiniu susidaro daugiausia hidratacijos produktu, todèl masès nuostoliai bandinyje yra 10-20\% didesni nei kontroliniame bandinyje ir bandiniuose su pavieniais SP.

8. Nustatyta, kad po 28 parų kietèjimo, palyginus su kontrolinio bandinio gniuždymo stipriu (87 MPa), bandinių su SP (A), SP (B), SP (C) ir SP mišiniu, gniuždymo stipris padidèjo $2,3 \%, 12,6 \%, 14,9 \%$ ir $32,2 \%$. Geriausius lenkimo stiprio rezultatus parode bandiniai su SP (A) ir SP mišiniu, kurių vertė po 28 parų kietèjimo buvo $7 \%$ ir $6 \%$ didesnè už kontrolinio bandinio lenkimo stiprị.

9. Nustatyta, kad bandiniuose su plastifikuojančių betono įmaišų mišiniu ir orą įtraukiančia įmaiša, didinant daugiasienių anglies nano vamzdelių kiekị (nuo 0,0005 iki 0,5\%), bandinių tankis, lyginant su kontroliniu bandiniu, mažèja atitinkamai 3,3\%,7,1\%,10,1\%, 11,2\% ir $10,1 \%$, o poringumas dideja $0,5 \%, 3,5 \%, 4,7 \%, 9,2 \%$ ir $10,6 \%$. Mažesni daugiasienių anglies nano vamzdelių (iki 0,005\%) kiekiai po 2-28 parų kietejjimo padidina gniuždymo stiprị 6 ir $9 \%$, o didesni $(0,05$ ir $0,5 \%)$ daugiasienių anglies nano vamzdelių kiekiai yra neefektyvūs, nes mažina gniuždymo stiprio vertes $3-12,8 \%$.

10. Nustatyta, kad trupintu polistireninio putplasčio atliekų vandens absorbcija (po $1 \mathrm{~h}$ ir po 28 paru) bandymo laikotarpiu padidèja nuo $39 \%$ iki $96 \%$, nes paviršiaus struktūra yra mažiau pažeista. Frezuotų polistireninio putplasčio atliekų struktūra, kurioje yra didelis kiekis skirtingo dydžio oro tuštumų ir ertmių, yra pažeista stipriau, todẻl vanduo užpildo visas jų ertmes ir vandens ịgeriamumas padidèja nuo $200 \%$ iki $382 \%$.

11. Atlikus kompozicinès medžiagos tyrimus, nustatyta, kad sudètyje be daugiasienių anglies nano vamzdelių priedo, didinant trupintos polistireninio putplasčio atliekos kiekį, tankis dèsningai mažèja nuo $830 \mathrm{iki}$ $310 \mathrm{~kg} / \mathrm{m}^{3}$, o gniuždymo stipris - nuo 6,5 iki $0,7 \mathrm{MPa}$. Šilumos laidumo koeficientas mažeja nuo 0,233 iki 0,09671 W/(m·K). I kompozito sudèti ịdejjus $0,005 \%$ daugiasienių anglies nano vamzdelių (nuo cemento kiekio), tankio vertès dar mažèja nuo 7 iki $21 \%$, gniuždymo stiprio vertés didèja nuo 3 iki $33 \%$, o šilumos laidumo koeficientas dar mažejja 4-18 \%. Didžiausias stiprio augimas nustatytas tuose bandiniuose, kuriuose trupintų ir frezuotų polistireninio putplasčio atliekų santykis apytiksliai lygus. 


\section{Bendrosios išvados}

1. Nustatyta, kad daugiasieniai anglies nano vamzdeliai, cemento tešloje prailgina rišimosi pradžios ir pabaigos trukmę, lyginant su kontroliniu bandiniu. Efektyviausiai cemento akmens gniuždymo stiprị palyginus su kontroliniu bandiniu po 2, 7 ir 28 parų kietejimo didina $0,005 \%$ (nuo cemento masès), optimalus daugiasienių anglies nano vamzdelių kiekis, o $0,05 \%$ ir 0,5 \% kiekiai sumažina gniuždymo stiprị.

2. Nustatyta, kad efektyviausiai cemento tešlos klampą su optimaliu $0,005 \%$ (nuo cemento masès), daugiasienių anglies nano vamzdeliu kiekiu tarp ištirtų plastifikuojančių betono ịmaišų (lignosulfonatų, poliakrilatų ir polikarboksilatų pagrindu) mažina plastifikuojančių betono ịmaišų mišinys, sudarytas iš poliakrilato ir polikarboksilato, kurių santykis mišinyje buvo 1:1. Cemento tešlos klampa su plastifikuojančių betono įmaišų mišiniu, lyginant su kitomis bandytomis plastifikuojančiomis betono ịmaišomis, buvo iki 2,5 kartų mažesnè, o tai leidžia sumažinti $\mathrm{V} / \mathrm{C}$ tešloje. 
3. Plastifikuojančių betono įmaišų mišinys, lyginant su kontroliniu bandiniu, mažiausiai keičia cemento tešlos su $0,005 \%$ daugiasienių anglies nano vamzdelių kiekiu, egzoterminès reakcijos eigą: pailgina egzoterminès reakcijos maksimumo laiką 0,8 val., nepakeisdamas egzoterminès reakcijos maksimumo temperatūros.

4. Rentgenografiniai ir termografiniai tyrimai, atlikti po 28 parų kietèjimo rodo, kad kontrolinis ir bandiniai su daugiasieniais anglies nano vamzdeliais ir plastifikuojančiomis betono įmaišomis turèjo panašią mineralinę sudètį, tačiau bandiniuose su plastifikuojančia betono imaiša lignosulfonatu pagrindu intensyviau formuojasi etringitas, o bandiniuose su plastifikuojančių betono įmaišų mišiniu dèl sąveikos su daugiasieniais anglies nano vamzdeliais susidaro daugiausiai hidratacijos produktų, todèl masès nuostoliai bandinyje yra (10-20\%) didesni nei kontroliniame ir bandiniuose su pavienemis plastifikuojančiomis betono įmaišomis.

5. Didesnis hidratacijos produktų kiekis bandiniuose su plastifikuojančių betono įmaišų mišiniu lemia didesnes gniuždymo stiprio vertes (iki $25 \%$ po 28 parų kietejjimo), lyginant su kontroliniu ir bandiniais su pavienèmis plastifikuojančiomis betono ịmaišomis.

6. Daugiasienių anglies nano vamzdelių priedas $(0,005 \%)$ kartu su plastifikuojančių betono ịmaišų mišiniu ir orą ịtraukiančia įmaiša didina cemento akmens atvirą poringumą, skatina smulkiaporès struktūros susidarymą, ir dèl armuojančio poveikio didina bandinių gniuždymo stiprị. Bandinių gniuždymo stipris ir atvirasis poringumas po 28 parų kietejjimo didejjo $13,6 \%$ ir $5 \%$, o tankis mažejo $11 \%$.

7. Remiantis tyrimų rezultatais sukurtas kompozitas, kurio eksploatacinès savybės yra analogiškos arba geresnès, nei akytojo betono gaminiu savybès. Kompozito sudètyje be daugiasienių anglies nano vamzdelių priedo, didinant trupinto polistireninio putplasčio atliekos kiekị, tankis ir gniuždymo stipris dèsningai mažèja nuo $830 \mathrm{iki} 310 \mathrm{~kg} / \mathrm{m}^{3}$ ir nuo 6,5 iki 0,7 MPa. Dėl daugiasienių anglies nano vamzdelių sąveikos su plastifikuojančių betono ịmaišų mišiniu ir orą ịtraukiančia įmaiša formavimo mišiniai ịtraukia daugiau oro ir todèl mažejja kompozitų tankis nuo 7 iki $21 \%$.

8. Nustatyta, kad dèl daugiasienių anglies nano vamzdelių armuojančio poveikio ir didesnio hidratacijos produktų kiekio, kompozitu gniuždymo stipris didèja nuo 3 iki 33 \% lyginant su analogiškais bandiniais be nano priedo. 
9. Didžiausias stiprio augimas stebimas sudètyse, kuriose trupinto polistireninio putplasčio atliekos ir polistireninio putplasčio frezavimo nuopjovų atliekos santykis yra $2 / 2$ ir 3/1. Jų struktūrinio efektyvumo rodiklis yra 71,2 \% ir 85,2 \% aukštesnis lyginant su analogiškais kompozitais be daugiasienių anglies nano vamzdelių priedo.

10. Dèl daugiasienių anglies nano vamzdelių sąveikos su plastifikuojančių betono įmaišų mišiniu ir orą įtraukiančia įmaiša formavimo mišiniai įtraukdami daugiau oro nei kompozituose be daugiasieniu anglies nano vamzdelių priedo sudaro smulkiaporę struktūrą, pasižyminčią mažesniu šilumos laidumo koeficientu ir geresniu garu pralaidumu. Didinant trupinto polistireninio putplasčio taros atliekos kiekị kompozito sudetyje be daugiasienių anglies nano vamzdeliu priedo, šilumos laidumo koeficientas mažeja nuo 0,233 iki $0,097 \mathrm{~W} /(\mathrm{m} \cdot \mathrm{K})$, o analogiškose sudètyse su šiuo priedu šilumos laidumo koeficientas mažèja 4-18 proc. ribose. 



\section{Literatūra ir šaltiniai}

Abu Al-Rub, R. K., Ashour, A. I., \& Tyson, B. M. (2012). On the aspect ratio effect of multi-walled carbon nanotube reinforcements on the mechanical properties of cementitious nanocomposites. Construction and Building Materials, 35, 647-655. https://doi.org/10.1016/j.conbuildmat.2012.04.086

Abu Al-Rub, R. K., Tyson, B. M., Yazdanbakhsh, A., \& Grasley, Z. (2012). Mechanical Properties of Nanocomposite Cement Incorporating Surface-Treated and Untreated Carbon Nanotubes and Carbon Nanofibers. Journal of Nanomechanics and Micromechanics, 2(1), 1-6. https://doi.org/10.1061/(ASCE)NM.2153-5477.0000041

Aiad, I., El-Sabbagh, A. M., Adawy, A. I., Shafek, S. H., \& Abo-EL-Enein, S. A. (2018). Effect of some prepared superplasticizers on the rheological properties of oil well cement slurries. Egyptian Journal of Petroleum, 27(4), 1061-1066.

https://doi.org/10.1016/j.ejpe.2018.03.011

Ajayan, P. M. (1999). Nanotubes from Carbon. Chemical Reviews, 99(7), 1787-1799. https://doi.org/10.1021/cr970102g

Alatawna, A., Birenboim, M., Nadiv, R., Buzaglo, M., Peretz-Damari, S., Peled, A., ... Sripada, R. (2020). The effect of compatibility and dimensionality of carbon nanofillers on cement composites. Construction and Building Materials, 232, 117141. https://doi.org/10.1016/j.conbuildmat.2019.117141 
Amin, M. S., El-Gamal, S. M. A., \& Hashem, F. S. (2015). Fire resistance and mechanical properties of carbon nanotubes - Clay bricks wastes (Homra) composites cement. Construction and Building Materials, 98, 237-249.

https://doi.org/10.1016/j.conbuildmat.2015.08.074

Arash, B., Park, H. S., \& Rabczuk, T. (2015). Mechanical properties of carbon nanotube reinforced polymer nanocomposites: A coarse-grained model. Composites Part B: Engineering, 80, 92-100. https://doi.org/10.1016/j.compositesb.2015.05.038

Ashraf, M., Naeem Khan, A., Ali, Q., Mirza, J., Goyal, A., \& Anwar, A. M. (2009). Physico-chemical, morphological and thermal analysis for the combined pozzolanic activities of minerals additives. Construction and Building Materials, 23(6), 2207-2213. https://doi.org/10.1016/j.conbuildmat.2008.12.008

Baloch, W. L., Khushnood, R. A., Memon, S. A., Ahmed, W., \& Ahmad, S. (2018). Effect of Elevated Temperatures on Mechanical Performance of Normal and Lightweight Concretes Reinforced with Carbon Nanotubes. Fire Technology, 54(5), 1331-1367. https://doi.org/10.1007/s10694-018-0733-z

Bandow, S., Chen, G., Sumanasekera, G. U., Gupta, R., Yudasaka, M., Iijima, S., ... Eklund, P. C. (2002). Diameter-selective resonant Raman scattering in double-wall carbon nanotubes. Physical Review B - Condensed Matter and Materials Physics, 66(7), 754161754168. https://doi.org/10.1103/PhysRevB.66.075416

Bishop, M., \& Barron, A. R. (2006). Cement hydration inhibition with sucrose, tartaric acid, and lignosulfonate: Analytical and spectroscopic study. Industrial and Engineering Chemistry Research, 45(21), 7042-7049. https://doi.org/10.1021/ie060806t

Björnström, J., \& Chandra, S. (2003). Effect of superplasticizers on the rheological properties of cements. Materials and Structures/Materiaux et Constructions, 36(264), 685-692. https://doi.org/10.1617/13912

Blandine, F., Habermehl-Ćwirzeń, K., \& Cwirzen, A. (2016). Contribution of CNTs/CNFs morphology to reduction of autogenous shrinkage of Portland cement paste. Frontiers of Structural and Civil Engineering, 10(2), 224-235. https://doi.org/10.1007/s11709-0160331-4

Bordere, S., Corpart, J. M., El Bounia, N. E., Gaillard, P., Passade-Boupat, N., Piccione, P. M., \& Plée, D. (2011). Industrial production and applications of carbon nanotubes. Arkema, Groupement de Recherches de Lacq. Available: Www. Graphistrength. Com, 1-7.

Burgos-Montes, O., Palacios, M., Rivilla, P., \& Puertas, F. (2012). Compatibility between superplasticizer admixtures and cements with mineral additions. Construction and Building Materials, 31, 300-309. https://doi.org/10.1016/j.conbuildmat.2011.12.092

Cadere, C. A., Barbuta, M., Rosca, B., Serbanoiu, A. A., Burlacu, A., \& Oancea, I. (2018). Engineering properties of concrete with polystyrene granules. Procedia Manufacturing, 22, 288-293. https://doi.org/10.1016/j.promfg.2018.03.044

Camacho, M. del C., Galao, O., Baeza, F. J., Zornoza, E., \& Garcés, P. (2014). Mechanical properties and durability of CNT cement composites. Materials, 7(3), 1640-1651. https://doi.org/10.3390/ma7031640 
Chaipanich, A., Nochaiya, T., Wongkeo, W., \& Torkittikul, P. (2010). Compressive strength and microstructure of carbon nanotubes-fly ash cement composites. Materials Science and Engineering A, 527(4-5), 1063-1067.

https://doi.org/10.1016/j.msea.2009.09.039

Chandni, T. J., \& Anand, K. B. (2018). Utilization of recycled waste as filler in foam concrete. Journal of Building Engineering, 19(April), 154-160.

https://doi.org/10.1016/j.jobe.2018.04.032

Chen, B, \& Liu, J. (2010). Experimental research on properties of foamed concrete reinforced with polypropylene fibers. Jianzhu Cailiao Xuebao/Journal of Building Materials, 13, 286-290+340. https://doi.org/10.3969/j.issn.1007-9629.2010.03.003

Chen, Baofan. (2013). Synthesis and properties of an AMPS-modified polyacrylic acid superplasticizer. Journal Wuhan University of Technology, Materials Science Edition, 28(3), 566-573. https://doi.org/10.1007/s11595-013-0732-3

Chen, Baofan. (2015). Effects of an AMPS-modified polyacrylic acid superplasticizer on the performance of cement-based materials. Journal Wuhan University of Technology, Materials Science Edition, 30(1), 109-116. https://doi.org/10.1007/s11595-015-1110-0

Chen, D., Guo, J., Xu, Y., Hu, M., Li, P., Jin, J., \& Yu, Y. (2019). Adsorption behavior and mechanism of a copolymer used as fluid loss additive in oil well cement. Construction and Building Materials, 198, 650-661.

https://doi.org/10.1016/j.conbuildmat.2018.11.184

Cheung, J., Jeknavorian, A., Roberts, L., \& Silva, D. (2011). Impact of admixtures on the hydration kinetics of Portland cement. Cement and Concrete Research, 41(12), 12891309. https://doi.org/10.1016/j.cemconres.2011.03.005

Chotard, T., Gimet-Breart, N., Smith, A., Fargeot, D., Bonnet, J. P., \& Gault, C. (2001). Application of ultrasonic testing to describe the hydration of calcium aluminate cement at the early age. Cement and Concrete Research, 31(3), 405-412. https://doi.org/10.1016/S0008-8846(00)00446-4

Collins, F., Lambert, J., \& Duan, W. H. (2012). The influences of admixtures on the dispersion, workability, and strength of carbon nanotube-OPC paste mixtures. Cement and Concrete Composites, 34(2), 201-207.

https://doi.org/10.1016/j.cemconcomp.2011.09.013

Crachereau, J. C., Gabas, N., Blouin, J., Hébrard, B., \& Maujean, A. (2001). Stabilisation tartrique des vins par la carboxyméthylcellulose. Bulletin de l'Oiv, 841-842.

Cui, H., Yan, X., Monasterio, M., \& Xing, F. (2017). Effects of various surfactants on the dispersion of MWCNTs-OH in aqueous solution. Nanomaterials, 7(9). https://doi.org/10.3390/nano7090262

Cui, H., Yang, S., \& Memon, S. A. (2015). Development of carbon nanotube modified cement paste with microencapsulated phase-change material for structural-functional integrated application. International Journal of Molecular Sciences, 16(4), 8027-8039. https://doi.org/10.3390/ijms 16048027

Cwirzen, A., Habermehl-Cwirzen, K., Nasibulin, A. G., Kaupinen, E. I., Mudimela, P. R., \& Penttala, V. (2009). SEM/AFM studies of cementitious binder modified by MWCNT 
and nano-sized $\mathrm{Fe}$ needles. Materials Characterization, 60(7), 735-740. https://doi.org/10.1016/j.matchar.2008.11.001

Cwirzen, Andrzej, \& Habermehl-Cwirzen, K. (2013). The effect of carbon nano- and microfibers on strength and residual cumulative strain of mortars subjected to freeze-thaw cycles. Journal of Advanced Concrete Technology, 11(3), 80-88.

https://doi.org/10.3151/jact.11.80

del Rio Merino, M., Villoria Sáez, P., Longobardi, I., Santa Cruz Astorqui, J., \& PorrasAmores, C. (2019). Redesigning lightweight gypsum with mixes of polystyrene waste from construction and demolition waste. Journal of Cleaner Production, 220, 144-151. https://doi.org/10.1016/j.jclepro.2019.02.132

Demidova-Buiziniene, I., \& Pundiene, I. (2015). Study of the Effect of Composite Deflocculant on Changes in Physical and Mechanical Properties of Heat-Resistant Concrete During Heat Treatment. Refractories and Industrial Ceramics, 55(5), 480-486. https://doi.org/10.1007/s11148-015-9748-x

Dixit, A., Pang, S. D., Kang, S. H., \& Moon, J. (2019). Lightweight structural cement composites with expanded polystyrene (EPS) for enhanced thermal insulation. Cement and Concrete Composites, 102(April), 185-197.

https://doi.org/10.1016/j.cemconcomp.2019.04.023

Eitan, A., Jiang, K., Dukes, D., Andrews, R., \& Schadler, L. S. (2003). Surface modification of multiwalled carbon nanotubes: Toward the tailoring of the interface in polymer composites. Chemistry of Materials, 15(16), 3198-3201.

https://doi.org/10.1021/cm020975d

Esawi, A. M. K., \& Farag, M. M. (2007). Carbon nanotube reinforced composites: Potential and current challenges. Materials and Design, 28(9), 2394-2401. https://doi.org/10.1016/j.matdes.2006.09.022

estatistika. (2019). https://osp.stat.gov.lt/. Retrieved from https://osp.stat.gov.lt/statistiniurodikliu-analize?indicator=S1R124\#/

Falliano, D., De Domenico, D., Ricciardi, G., \& Gugliandolo, E. (2018). Experimental investigation on the compressive strength of foamed concrete: Effect of curing conditions, cement type, foaming agent and dry density. Construction and Building Materials, 165, 735-749. https://doi.org/10.1016/j.conbuildmat.2017.12.241

Fathi, M., Yousefipour, A., \& Hematpoury Farokhy, E. (2017). Mechanical and physical properties of expanded polystyrene structural concretes containing Micro-silica and Nanosilica. Construction and Building Materials, 136, 590-597.

https://doi.org/10.1016/j.conbuildmat.2017.01.040

Feng, H., Pan, L., Zheng, Q., Li, J., Xu, N., \& Pang, S. (2018). Effects of molecular structure of polycarboxylate superplasticizers on their dispersion and adsorption behavior in cement paste with two kinds of stone powder. Construction and Building Materials, 170, 182-192. https://doi.org/10.1016/j.conbuildmat.2018.02.195

Ferrándiz-Mas, V., \& García-Alcocel, E. (2013). Durability of expanded polystyrene mortars. Construction and Building Materials, 46, 175-182.

https://doi.org/10.1016/j.conbuildmat.2013.04.029 
Ferrari, L., Bernard, L., Deschner, F., Kaufmann, J., Winnefeld, F., \& Plank, J. (2012). Characterization of polycarboxylate-ether based superplasticizer on cement clinker surfaces. Journal of the American Ceramic Society, 95(7), 2189-2195. https://doi.org/10.1111/j.1551-2916.2012.05189.x

Gabrovšek, R., Vuk, T., \& Kaučič, V. (2008). The preparation and thermal behavior of calcium monocarboaluminate. Acta Chimica Slovenica, 55(4), 942-950.

Galao, O., Zornoza, E., Baeza, F. J., Bernabeu, A., \& Garcés, P. (2012). Efecto de la adición de nanofibras de carbono en las propiedades mecánicas y de durabilidad de materiales cementantes. Materiales de Construccion, 62(307), 343-357. https://doi.org/10.3989/mc.2012.01211

Gelardi, G., \& Flatt, R. J. (2016). Working mechanisms of water reducers and superplasticizers. Science and Technology of Concrete Admixtures (Vol. 2). Elsevier Ltd. https://doi.org/10.1016/B978-0-08-100693-1.00011-4

Gerard Lavin, J., Subramoney, S., Ruoff, R. S., Berber, S., \& Tománek, D. (2002). Scrolls and nested tubes in multiwall carbon nanotubes. Carbon, 40(7), 1123-1130. https://doi.org/10.1016/S0008-6223(02)00050-7

Gökçe, H. S., Hatungimana, D., \& Ramyar, K. (2019). Effect of fly ash and silica fume on hardened properties of foam concrete. Construction and Building Materials, 194, 111. https://doi.org/10.1016/j.conbuildmat.2018.11.036

Gregorova, V., Ledererova, M., \& Stefunkova, Z. (2017). Investigation of Influence of Recycled Plastics from Cable, Ethylene Vinyl Acetate and Polystyrene Waste on Lightweight Concrete Properties. Procedia Engineering, 195, 127-133. https://doi.org/10.1016/j.proeng.2017.04.534

Guan, X., Bai, S., Li, H., \& Ou, J. (2020). Mechanical properties and microstructure of multi-walled carbon nanotube-reinforced cementitious composites under the early-age freezing conditions. Construction and Building Materials, 233, 117317. https://doi.org/10.1016/j.conbuildmat.2019.117317

Guo, Y., Ma, B., Zhi, Z., Tan, H., Liu, M., Jian, S., \& Guo, Y. (2017). Effect of polyacrylic acid emulsion on fluidity of cement paste. Colloids and Surfaces A: Physicochemical and Engineering Aspects, 535(September), 139-148.

https://doi.org/10.1016/j.colsurfa.2017.09.039

Hamada, D., Sagawa, K., Tanisho, Y., \& Yamamuro, H. (2009). Pursuance of workability retention by new superplasticizer. American Concrete Institute, ACI Special Publication, 297-307.

Han, B., Yang, Z., Shi, X., \& Yu, X. (2013). Transport properties of carbonnanotube/cement composites. Journal of Materials Engineering and Performance, 22(1), 184-189. https://doi.org/10.1007/s11665-012-0228-X

Han, B., Zhang, K., \& Yu, X. (2013). Enhance the thermal storage of cement-based composites with phase change materials and carbon nanotubes. Journal of Solar Energy Engineering, Transactions of the ASME, 135(2), 3-7. https://doi.org/10.1115/1.4023181

Handling, S., \& Guide, S. H. (2012). Safe Handling Guide GRAPHISTRENGTH MultiWalled Carbon Nanotubes, (November), 1-4. 
Harrison, B. S., \& Atala, A. (2007). Carbon nanotube applications for tissue engineering. Biomaterials, 28(2), 344-353. https://doi.org/10.1016/j.biomaterials.2006.07.044

Hartman, M. R., Brady, S. K., Berliner, R., \& Conradi, M. S. (2006). The evolution of structural changes in ettringite during thermal decomposition. Journal of Solid State Chemistry, 179(4), 1259-1272. https://doi.org/10.1016/j.jssc.2006.01.038

He, X. Q., Kitipornchai, S., Wang, C. M., \& Liew, K. M. (2005). Modeling of van der Waals force for infinitesimal deformation of multi-walled carbon nanotubes treated as cylindrical shells. International Journal of Solids and Structures, 42(23), 6032-6047. https://doi.org/10.1016/j.ijsolstr.2005.03.045

Hilal, A. A., Thom, N. H., \& Dawson, A. R. (2015). On entrained pore size distribution of foamed concrete. Construction and Building Materials, 75, 227-233. https://doi.org/10.1016/j.conbuildmat.2014.09.117

Hogancamp, J., \& Grasley, Z. (2017). The use of microfine cement to enhance the efficacy of carbon nanofibers with respect to drying shrinkage crack resistance of portland cement mortars. Cement and Concrete Composites, 83, 405-414.

https://doi.org/10.1016/j.cemconcomp.2017.08.006

Houst, Y. F., Bowen, P., Perche, F., Kauppi, A., Borget, P., Galmiche, L., ... Reknes, K. (2008). Design and function of novel superplasticizers for more durable high performance concrete (superplast project). Cement and Concrete Research, 38(10), 1197-1209. https://doi.org/10.1016/j.cemconres.2008.04.007

Hu, Y., Luo, D., Li, P., Li, Q., \& Sun, G. (2014). Fracture toughness enhancement of cement paste with multi-walled carbon nanotubes. Construction and Building Materials, 70, 332-338. https://doi.org/10.1016/j.conbuildmat.2014.07.077

Huang, Y., Li, H., Jiang, Z., Yang, X., \& Chen, Q. (2018). Migration and transformation of sulfur in the municipal sewage sludge during disposal in cement kiln. Waste Management, 77, 537-544. https://doi.org/10.1016/j.wasman.2018.05.001

Huynh, L., Beattie, D. A., Fornasiero, D., \& Ralston, J. (2006). Effect of polyphosphate and naphthalene sulfonate formaldehyde condensate on the rheological properties of dewatered tailings and cemented paste backfill. Minerals Engineering, 19(1), 28-36. https://doi.org/10.1016/j.mineng.2005.05.001

Ibragimov, R., \& Fediuk, R. (2019). Improving the early strength of concrete: Effect of mechanochemical activation of the cementitious suspension and using of various superplasticizers. Construction and Building Materials, 226, 839-848. https://doi.org/10.1016/j.conbuildmat.2019.07.313

Jalal, M., Teimortashlu, E., \& Grasley, Z. (2019). Performance-based design and optimization of rheological and strength properties of self-compacting cement composite incorporating micro/ nano admixtures. Composites Part B: Engineering, 163(June 2018), 497-510. https://doi.org/10.1016/j.compositesb.2019.01.028

Jiao, D., Shi, C., Yuan, Q., An, X., Liu, Y., \& Li, H. (2017). Effect of constituents on rheological properties of fresh concrete-A review. Cement and Concrete Composites, 83, 146-159. https://doi.org/10.1016/j.cemconcomp.2017.07.016

Karpova, E. (2020). Influence of carbon nanotubes on the effectiveness of plasticizers, 
hydration and structure of cement-based materials. VGTU Leidykla TECHNIKA, 2020. https://doi.org/10.20334/2020-028-m

Kashcheev, I. D., Zemlyanoi, K. G., Kormina, I. V., \& Markova, S. V. (2011). Effect of surfactants on aluminosilcate refractory properties. Refractories and Industrial Ceramics, 52(2), 136-142. https://doi.org/10.1007/s11148-011-9382-1

Ke, Y., Beaucour, A. L., Ortola, S., Dumontet, H., \& Cabrillac, R. (2009). Influence of volume fraction and characteristics of lightweight aggregates on the mechanical properties of concrete. Construction and Building Materials, 23(8), 2821-2828. https://doi.org/10.1016/j.conbuildmat.2009.02.038

Keriene, J., Kligys, M., Laukaitis, A., Yakovlev, G., Špokauskas, A., \& Aleknevičius, M. (2013). The influence of multi-walled carbon nanotubes additive on properties of nonautoclaved and autoclaved aerated concretes. Construction and Building Materials, 49, 527-535. https://doi.org/10.1016/j.conbuildmat.2013.08.044

Kim, G. M., Nam, I. W., Yoon, H. N., \& Lee, H. K. (2018). Effect of superplasticizer type and siliceous materials on the dispersion of carbon nanotube in cementitious composites. Composite Structures, 185(September 2017), 264-272.

https://doi.org/10.1016/j.compstruct.2017.11.011

Kim, H. K., Nam, I. W., \& Lee, H. K. (2014). Enhanced effect of carbon nanotube on mechanical and electrical properties of cement composites by incorporation of silica fume. Composite Structures, 107, 60-69. https://doi.org/10.1016/j.compstruct.2013.07.042

Kligys, M. (2009). Kompozitinès medžiagos iš poringosios cemento tešlos ir trupinto polistireninio putplasčio gamybos technologija ir savybès. Vilnius: VGTU leidykla TECHNIKA, 2009.

Koksal, F., Mutluay, E., \& Gencel, O. (2020). Characteristics of isolation mortars produced with expanded vermiculite and waste expanded polystyrene. Construction and Building Materials, 236, 117789. https://doi.org/10.1016/j.conbuildmat.2019.117789

Kong, F. R., Pan, L. S., Wang, C. M., Zhang, D. La, \& Xu, N. (2016). Effects of polycarboxylate superplasticizers with different molecular structure on the hydration behavior of cement paste. Construction and Building Materials, 105, 545-553. https://doi.org/10.1016/j.conbuildmat.2015.12.178

Konsta-Gdoutos, M. S., Batis, G., Danoglidis, P. A., Zacharopoulou, A. K., Zacharopoulou, E. K., Falara, M. G., \& Shah, S. P. (2017). Effect of CNT and CNF loading and count on the corrosion resistance, conductivity and mechanical properties of nanomodified OPC mortars. Construction and Building Materials, 147, 48-57. https://doi.org/10.1016/j.conbuildmat.2017.04.112

Konsta-Gdoutos, M. S., Danoglidis, P. A., Falara, M. G., \& Nitodas, S. F. (2017). Fresh and mechanical properties, and strain sensing of nanomodified cement mortars: The effects of MWCNT aspect ratio, density and functionalization. Cement and Concrete Composites, 82, 137-151. https://doi.org/10.1016/j.cemconcomp.2017.05.004

Konsta-Gdoutos, M. S., Metaxa, Z. S., \& Shah, S. P. (2010a). Highly dispersed carbon nanotube reinforced cement based materials. Cement and Concrete Research, 40(7), 1052-1059. https://doi.org/10.1016/j.cemconres.2010.02.015 
Konsta-Gdoutos, M. S., Metaxa, Z. S., \& Shah, S. P. (2010b). Multi-scale mechanical and fracture characteristics and early-age strain capacity of high performance carbon nanotube/cement nanocomposites. Cement and Concrete Composites, 32(2), 110-115. https://doi.org/10.1016/j.cemconcomp.2009.10.007

Kordkheili, H. Y., Hiziroglu, S., \& Farsi, M. (2012). Some of the physical and mechanical properties of cement composites manufactured from carbon nanotubes and bagasse fiber. Materials and Design, 33(1), 395-398. https://doi.org/10.1016/j.matdes.2011.04.027

Kostrzanowska-Siedlarz, A. (2020). Statistical methods for determining rheological parameters of mortars modified with multi-walled carbon nanotubes. Construction and Building Materials, 253, 119213. https://doi.org/10.1016/j.conbuildmat.2020.119213

Kovler, K., \& Roussel, N. (2011). Properties of fresh and hardened concrete. Cement and Concrete Research, 41(7), 775-792. https://doi.org/10.1016/j.cemconres.2011.03.009

Laukaitis, A., Kerienè, J., Kligys, M., Mikulskis, D., \& Lekūnaite, L. (2012). Influence of mechanically treated carbon fibre additives on structure formation and properties of autoclaved aerated concrete. Construction and Building Materials, 26(1), 362-371. https://doi.org/10.1016/j.conbuildmat.2011.06.035

Li, G. Y., Wang, P. M., \& Zhao, X. (2005). Mechanical behavior and microstructure of cement composites incorporating surface-treated multi-walled carbon nanotubes. Carbon, 43(6), 1239-1245. https://doi.org/10.1016/j.carbon.2004.12.017

Li, G. Y., Wang, P. M., \& Zhao, X. (2007). Pressure-sensitive properties and microstructure of carbon nanotube reinforced cement composites. Cement and Concrete Composites, 29(5), 377-382. https://doi.org/10.1016/j.cemconcomp.2006.12.011

Li, H., Zhang, Q., \& Xiao, H. (2013). Self-deicing road system with a CNFP highefficiency thermal source and MWCNT/cement-based high-thermal conductive composites. Cold Regions Science and Technology, 86, 22-35.

https://doi.org/10.1016/j.coldregions.2012.10.007

Li, W. W., Ji, W. M., Wang, Y. C., Liu, Y., Shen, R. X., \& Xing, F. (2015). Investigation on the mechanical properties of a cement-based material containing carbon nanotube under drying and freeze-thaw conditions. Materials, 8(12), 8780-8792. https://doi.org/10.3390/ma8125491

Li, X. K., Zheng, D. F., Zheng, T., Lin, X. L., Lou, H. ming, \& Qiu, X. qing. (2017). Enhancement clay tolerance of PCE by lignin-based polyoxyethylene ether in montmorillonite-contained paste. Journal of Industrial and Engineering Chemistry, 49, 168-175. https://doi.org/10.1016/j.jiec.2017.01.024

Li, Y., Li, H., Wang, Z., \& Jin, C. (2020). Effect and mechanism analysis of functionalized multi-walled carbon nanotubes (MWCNTs) on C-S-H gel. Cement and Concrete Research, 128(100), 105955. https://doi.org/10.1016/j.cemconres.2019.105955

Li, Y., \& Lin, H. (2019). Experimental study on the effect of different dispersed degrees carbon nanotubes on the modification of magnesium phosphate cement. Construction and Building Materials, 200, 240-247. https://doi.org/10.1016/j.conbuildmat.2018.12.113

Li, Z., Corr, D. J., Han, B., \& Shah, S. P. (2020). Investigating the effect of carbon nanotube on early age hydration of cementitious composites with isothermal calorimetry 
and Fourier transform infrared spectroscopy. Cement and Concrete Composites, 107(December 2019), 103513. https://doi.org/10.1016/j.cemconcomp.2020.103513

Liebscher, M., Dinh, T. T., Schröfl, C., \& Mechtcherine, V. (2020). Dispersion of different carbon-based nanofillers in aqueous suspension by polycarboxylate comb-type copolymers and their influence on the early age properties of cementitious matrices. Construction and Building Materials, 241, 118039.

https://doi.org/10.1016/j.conbuildmat.2020.118039

Liebscher, M., Fuge, R., Schröfl, C., Lange, A., Caspari, A., Bellmann, C., ... Leonhardt, A. (2017). Temperature- and pH-Dependent Dispersion of Highly Purified Multiwalled Carbon Nanotubes Using Polycarboxylate-Based Surfactants in Aqueous Suspension. Journal of Physical Chemistry C, 121(31), 16903-16910. https://doi.org/10.1021/acs.jpcc.7b05534

Liebscher, M., Lange, A., Schröfl, C., Fuge, R., Mechtcherine, V., Plank, J., \& Leonhardt, A. (2017). Impact of the molecular architecture of polycarboxylate superplasticizers on the dispersion of multi-walled carbon nanotubes in aqueous phase. Journal of Materials Science, 52(4), 2296-2307. https://doi.org/10.1007/s10853-016-0522-3

Liew, K. M., Kai, M. F., \& Zhang, L. W. (2016). Carbon nanotube reinforced cementitious composites: An overview. Composites Part A: Applied Science and Manufacturing, 91, 301-323. https://doi.org/10.1016/j.compositesa.2016.10.020

Liu, J. Z., Zheng, Q. S., Wang, L. F., \& Jiang, Q. (2005). Mechanical properties of singlewalled carbon nanotube bundles as bulk materials. Journal of the Mechanics and Physics of Solids, 53(1), 123-142. https://doi.org/10.1016/j.jmps.2004.06.008

Liu, M., Lei, J. H., Du, X. Di, Huang, B., \& Chen, L. N. (2013). Synthesis and properties of methacrylate-based and allylether-based polycarboxylate superplasticizer in cementitious system. Journal of Sustainable Cement-Based Materials, 2(3-4), 218-226. https://doi.org/10.1080/21650373.2013.829758

Liu, Q., Sun, W., Jiang, H., \& Wang, C. (2014). Effects of carbon nanotubes on mechanical and 2D-3D microstructure properties of cement mortar. Journal Wuhan University of Technology, Materials Science Edition, 29(3), 513-517. https://doi.org/10.1007/s11595-014-0950-3

Luo, J., Hou, D., Li, Q., Wu, C., \& Zhang, C. (2017). Comprehensive performances of carbon nanotube reinforced foam concrete with tetraethyl orthosilicate impregnation. Construction and Building Materials, 131, 512-516.

https://doi.org/10.1016/j.conbuildmat.2016.11.105

Madandoust, R., Ranjbar, M. M., \& Yasin Mousavi, S. (2011). An investigation on the fresh properties of self-compacted lightweight concrete containing expanded polystyrene. Construction and Building Materials, 25(9), 3721-3731.

https://doi.org/10.1016/j.conbuildmat.2011.04.018

Makar, J. M.Margeson, J. C.; Luh, J. (2005). NRC Publications Archive ( NPArC ) Archives des publications du CNRC ( NPArC ) Carbon nanotube / cement composites early results and potential applications. Construction. 
Makar, J. M., \& Chan, G. W. (2009). Growth of cement hydration products on singlewalled carbon nanotubes. Journal of the American Ceramic Society, 92(6), 1303-1310. https://doi.org/10.1111/j.1551-2916.2009.03055.x

Mangane, M. B. C., Argane, R., Trauchessec, R., Lecomte, A., \& Benzaazoua, M. (2018a). Influence of superplasticizers on mechanical properties and workability of cemented paste backfill. Minerals Engineering, 116(October 2017), 3-14.

https://doi.org/10.1016/j.mineng.2017.11.006

Mangane, M. B. C., Argane, R., Trauchessec, R., Lecomte, A., \& Benzaazoua, M. (2018b). Influence of superplasticizers on mechanical properties and workability of cemented paste backfill. Minerals Engineering, 116(November 2017), 3-14. https://doi.org/10.1016/j.mineng.2017.11.006

Manzur, T., Yazdani, N., \& Emon, M. A. B. (2014). Effect of Carbon Nanotube Size on Compressive Strengths of Nanotube Reinforced Cementitious Composites. Journal of Materials, 2014, 1-8. https://doi.org/10.1155/2014/960984

Marchon, D., \& Flatt, R. J. (2016). Mechanisms of cement hydration. Science and Technology of Concrete Admixtures. Elsevier Ltd. https://doi.org/10.1016/B978-0-08100693-1.00008-4

Marchon, D., Mantellato, S., Eberhardt, A. B., \& Flatt, R. J. (2016). Adsorption of chemical admixtures. Science and Technology of Concrete Admixtures. Elsevier Ltd. https://doi.org/10.1016/B978-0-08-100693-1.00010-2

Marchon, Delphine, Kawashima, S., Bessaies-Bey, H., Mantellato, S., \& Ng, S. (2018). Hydration and rheology control of concrete for digital fabrication: Potential admixtures and cement chemistry. Cement and Concrete Research, 112(May), 96-110. https://doi.org/10.1016/j.cemconres.2018.05.014

Matarredona, O., Rhoads, H., Li, Z., Harwell, J. H., Balzano, L., \& Resasco, D. E. (2003). Dispersion of single-walled carbon nanotubes in aqueous solutions of the anionic surfactant NaDDBS. Journal of Physical Chemistry B, 107(48), 13357-13367. https://doi.org/10.1021/jp0365099

Meier, M. R., Napharatsamee, T., \& Plank, J. (2017). Dispersing performance of superplasticizers admixed to aged cement. Construction and Building Materials, 139, 232-240. https://doi.org/10.1016/j.conbuildmat.2016.12.126

Melo, V., Calixto, J., Ladeira, L., \& Silva, A. R. (2011). Macro- and MicroCharacterization of Mortars Produced with Carbon Nanotubes. ACI Materials Journal, $108,327-332$.

Mendoza, O., Sierra, G., \& Tobón, J. I. (2013). Influence of super plasticizer and $\mathrm{Ca}(\mathrm{OH}) 2$ on the stability of functionalized multi-walled carbon nanotubes dispersions for cement composites applications. Construction and Building Materials, 47, 771-778. https://doi.org/10.1016/j.conbuildmat.2013.05.100

Metaxa, Z. S., Seo, J. W. T., Konsta-Gdoutos, M. S., Hersam, M. C., \& Shah, S. P. (2012). Highly concentrated carbon nanotube admixture for nano-fiber reinforced cementitious materials. Cement and Concrete Composites, 34(5), 612-617.

https://doi.org/10.1016/j.cemconcomp.2012.01.006 
Mikanovic, N., \& Jolicoeur, C. (2008). Influence of superplasticizers on the rheology and stability of limestone and cement pastes. Cement and Concrete Research, 38(7), 907-919. https://doi.org/10.1016/j.cemconres.2008.01.015

Mlinárik, L., \& Kopecskó, K. (2013). Influence of metakaolin on chemical resistance of concrete. IOP Conference Series: Materials Science and Engineering, 47(1). https://doi.org/10.1088/1757-899X/47/1/012014

Mollah, M. Y. A., Yu, W., Schennach, R., \& Cocke, D. L. (2000). Fourier transform infrared spectroscopic investigation of the early hydration of Portland cement and the influence of sodium lignosulfonate. Cement and Concrete Research, 30(2), 267-273. https://doi.org/10.1016/S0008-8846(99)00243-4

Musso, S., Tulliani, J. M., Ferro, G., \& Tagliaferro, A. (2009). Influence of carbon nanotubes structure on the mechanical behavior of cement composites. Composites Science and Technology, 69(11-12), 1985-1990.

https://doi.org/10.1016/j.compscitech.2009.05.002

Nadiv, R., Vasilyev, G., Shtein, M., Peled, A., Zussman, E., \& Regev, O. (2016). The multiple roles of a dispersant in nanocomposite systems. Composites Science and Technology, 133, 192-199. https://doi.org/10.1016/j.compscitech.2016.07.008

Nambiar, E. K. K., \& Ramamurthy, K. (2006). Influence of filler type on the properties of foam concrete. Cement and Concrete Composites, 28(5), 475-480. https://doi.org/10.1016/j.cemconcomp.2005.12.001

Nasibulina, L. I., Anoshkin, I. V., Nasibulin, A. G., Cwirzen, A., Penttala, V., \& Kauppinen, E. I. (2012). Effect of carbon nanotube aqueous dispersion quality on mechanical properties of cement composite. Journal of Nanomaterials, 2012. https://doi.org/10.1155/2012/169262

$\mathrm{Ng}$, S., \& Justnes, H. (2015). Influence of dispersing agents on the rheology and early heat of hydration of blended cements with high loading of calcined marl. Cement and Concrete Composites, 60, 123-134. https://doi.org/10.1016/j.cemconcomp.2015.04.007

$\mathrm{Ng}$, S., \& Justnes, H. (2016). Influence of plasticizers on the rheology and early heat of hydration of blended cements with high content of fly ash. Cement and Concrete Composites, 65, 41-54. https://doi.org/10.1016/j.cemconcomp.2015.10.005

Ng, S., \& Plank, J. (2012). Interaction mechanisms between $\mathrm{Na}$ montmorillonite clay and MPEG-based polycarboxylate superplasticizers. Cement and Concrete Research, 42(6), 847-854. https://doi.org/10.1016/j.cemconres.2012.03.005

Ng, Serina, Metwalli, E., Müller-Buschbaum, P., \& Plank, J. (2013). Occurrence of intercalation of PCE superplasticizers in calcium aluminate cement under actual application conditions, as evidenced by SAXS analysis. Cement and Concrete Research, 54, 191-198. https://doi.org/10.1016/j.cemconres.2013.09.002

Nochaiya, T., \& Chaipanich, A. (2011). Behavior of multi-walled carbon nanotubes on the porosity and microstructure of cement-based materials. Applied Surface Science, 257(6), 1941-1945. https://doi.org/10.1016/j.apsusc.2010.09.030 
Nowak-Michta, A. (2019). Impact analysis of air-entraining and superplasticizing admixtures on concrete compressive strength. Procedia Structural Integrity, 23(2019), 77-82. https://doi.org/10.1016/j.prostr.2020.01.066

O’Connell, M. J., Boul, P., Ericson, L. M., Huffman, C., Wang, Y., Haroz, E., ... Smalley, R. E. (2001). Reversible water-solubilization of single-walled carbon nanotubes by polymer wrapping. Chemical Physics Letters, 342(3-4), 265-271. https://doi.org/10.1016/S0009-2614(01)00490-0

Ouattara, D., Yahia, A., Mbonimpa, M., \& Belem, T. (2017). Effects of superplasticizer on rheological properties of cemented paste backfills. International Journal of Mineral Processing, 161, 28-40. https://doi.org/10.1016/j.minpro.2017.02.003

Parveen, S., Rana, S., Fangueiro, R., \& Paiva, M. C. (2015). Microstructure and mechanical properties of carbon nanotube reinforced cementitious composites developed using a novel dispersion technique. Cement and Concrete Research, 73, 215-227. https://doi.org/10.1016/j.cemconres.2015.03.006

Payá, J., Monzó, J., Borrachero, M. V., Velázquez, S., \& Bonilla, M. (2003). Determination of the pozzolanic activity of fluid catalytic cracking residue. Thermogravimetric analysis studies on FC3R-lime pastes. Cement and Concrete Research, 33(7), 1085-1091. https://doi.org/10.1016/S0008-8846(03)00014-0

Peigney, A., Laurent, C., Flahaut, E., Bacsa, R. R., \& Rousset, A. (2001). Specific surface area of carbon nanotubes and bundles of carbon nanotubes. Carbon, 39(4), 507-514. https://doi.org/https://doi.org/10.1016/S0008-6223(00)00155-X

Petrunin, S., Vaganov, V., Reshetniak, V., \& Zakrevskaya, L. (2015). Influence of carbon nanotubes on the structure formation of cement matrix. IOP Conference Series: Materials Science and Engineering, 96(1). https://doi.org/10.1088/1757-899X/96/1/012046

Peyvandi, A., Sbia, L. A., Soroushian, P., \& Sobolev, K. (2013). Effect of the cementitious paste density on the performance efficiency of carbon nanofiber in concrete nanocomposite. Construction and Building Materials, 48, 265-269. https://doi.org/10.1016/j.conbuildmat.2013.06.094

Plank, J., Pöllmann, K., Zouaoui, N., Andres, P. R., \& Schaefer, C. (2008). Synthesis and performance of methacrylic ester based polycarboxylate superplasticizers possessing hydroxy terminated poly(ethylene glycol) side chains. Cement and Concrete Research, 38(10), 1210-1216. https://doi.org/10.1016/j.cemconres.2008.01.007

Plank, Johann, \& Hirsch, C. (2007). Impact of zeta potential of early cement hydration phases on superplasticizer adsorption. Cement and Concrete Research, 37(4), 537-542. https://doi.org/10.1016/j.cemconres.2007.01.007

Plank, Johann, Hirsch, C., Atarashi, D., Yamada, K. K., Itoh, A., Miyauchi, M., ... Enohata, T. (2012). Influence of solution chemistry on the hydration of polished clinker surfaces - A study of different types of polycarboxylic acid-based admixtures. Cement and Concrete Research, 32(2), 1-12. https://doi.org/10.1016/j.cemconcomp.2007.01.004

Plank, Johann, Schroefl, C., Gruber, M., Lesti, M., \& Sieber, R. (2009). Effectiveness of polycarboxylate superplasticizers in ultra-high strength concrete: The importance of PCE 
compatibility with silica fume. Journal of Advanced Concrete Technology, 7(1), 5-12. https://doi.org/10.3151/jact.7.5

Plank, Johann, Zhimin, D., Keller, H., Hössle, F. v., \& Seidl, W. (2010). Fundamental mechanisms for polycarboxylate intercalation into $\mathrm{C} 3 \mathrm{~A}$ hydrate phases and the role of sulfate present in cement. Cement and Concrete Research, 40(1), 45-57. https://doi.org/10.1016/j.cemconres.2009.08.013

Pourchet, S., Comparet, C., Nicoleau, L., \& Nonat, A. (2007). Influence of PC superplasticizers on tricalcium silicate hydration. 12th International Congress on the Chemistry of Cement., (May 2014).

Pundiene, I., Kičaite, A., \& Pranckevičiene, J. (2016). Impact of different types of plasticizing admixtures on the rheological properties and hydration of blended cements. Journal of Thermal Analysis and Calorimetry, 123(2), 1099-1109. https://doi.org/10.1007/s10973-015-5020-3

Radlinska, A., Rajabipour, F., Bucher, B., Henkensiefken, R., Sant, G., \& Weiss, J. (2008). Shrinkage mitigation strategies in cementitious systems: A closer look at differences in sealed and unsealed behavior. Transportation Research Record, (2070), 59-67. https://doi.org/10.3141/2070-08

Reinhardt, H. W., \& Grosse, C. U. (2004). Continuous monitoring of setting and hardening of mortar and concrete. Construction and Building Materials, 18(3), 145-154. https://doi.org/10.1016/j.conbuildmat.2003.10.002

Richard, C., Balavoine, F., Schultz, P., Ebbesen, T. W., \& Mioskowski, C. (2003). Supramolecutar self-assembly of lipid derivatives on carbon nanotubes. Science, 300(5620), 775-778. https://doi.org/10.1126/science.1080848

Ridi, F., Fratini, E., Luciani, P., Winnefeld, F., \& Baglioni, P. (2012). Tricalcium silicate hydration reaction in the presence of comb-shaped superplasticizers: Boundary nucleation and growth model applied to polymer-modified pastes. Journal of Physical Chemistry C, 116(20), 10887-10895. https://doi.org/10.1021/jp209156n

Robert, C. R., Sathyan, D., \& Anand, K. B. (2018). Effect of superplasticizers on the rheological properties of fly ash incorporated cement paste. Materials Today: Proceedings, 5(11), 23955-23963. https://doi.org/10.1016/j.matpr.2018.10.188

Robeyst, N., Gruyaert, E., Grosse, C. U., \& De Belie, N. (2008). Monitoring the setting of concrete containing blast-furnace slag by measuring the ultrasonic p-wave velocity. Cement and Concrete Research, 38(10), 1169-1176.

https://doi.org/10.1016/j.cemconres.2008.04.006

Sakai, E., Yamada, K., \& Ohta, A. (2003). Molecular Structure and DispersionAdsorption Mechanisms of Comb-Type Superplasticizers Used in Japan. Journal of Advanced Concrete Technology, 1(1), 16-25. https://doi.org/10.3151/jact.1.16

Sanchez, F., Zhang, L., \& Ince, C. (2009). Multi-scale Performance and Durability of Carbon Nanofiber/Cement Composites. Nanotechnology in Construction 3, 345-350. https://doi.org/10.1007/978-3-642-00980-8_46

Šeputytė-Jucike,, J. (2016). Priedu ir lengvujų užpildu poveikis termoizoliacinio cementinio kompozito struktūrai ir savybèms. VGTU leidykla TECHNIKA, 2016, Vilnius. 
Sha, W., O'Neill, E. A., \& Guo, Z. (1999). Differential scanning calorimetry study of ordinary Portland cement. Cement and Concrete Research, 29(9), 1487-1489. https://doi.org/10.1016/S0008-8846(99)00128-3

Shao, H., Chen, B., Li, B., Tang, S., \& Li, Z. (2017). Influence of dispersants on the properties of CNTs reinforced cement-based materials. Construction and Building Materials, 131, 186-194. https://doi.org/10.1016/j.conbuildmat.2016.11.053

Shi, T., Li, Z., Guo, J., Gong, H., \& Gu, C. (2019a). Research progress on CNTs/CNFsmodified cement-based composites - A review. Construction and Building Materials, 202, 290-307. https://doi.org/10.1016/j.conbuildmat.2019.01.024

Shi, T., Li, Z., Guo, J., Gong, H., \& Gu, C. (2019b). Research progress on CNTs / CNFsmodified cement-based composites - A review Research progress on CNTs / CNFsmodified cement-based composites - A review. Construction and Building Materials, 202(2008), 290-307. https://doi.org/10.1016/j.conbuildmat.2019.01.024

Siddique, R., \& Mehta, A. (2014). Effect of carbon nanotubes on properties of cement mortars. Construction and Building Materials, 50, 116-129.

https://doi.org/10.1016/j.conbuildmat.2013.09.019

Simon, D., Grabinsky, M. W., \& Bawden, W. (2011). Effect of polycarboxylated acrylic acid polymer- based superplasticizer on cemented paste backfill. 2011 Pan-Am CGS Geotechnical Conference: 64th Canadian Geotechnical Conference and 14th PanAmerican Conference on Soil Mechanics and Geotechnical Engineering, 1-8.

Sinica, M. (2001). Dispersiniu ir pluoštiniu intarpu ịtaka kompozitu iš porizuoto betono savybems: daktaro disertacija (book). Vilniaus Gedimino technikos universitetas. Prieiga per eLABa - nacionalinè Lietuvos akademinè elektroninè biblioteka, Vilnius.

Smith, A., Chotard, T., Gimet-Breart, N., \& Fargeot, D. (2002). Ultrasonic measurements as an in situ tool for characterising the ageing of an aluminous cement at different temperatures. Journal of the European Ceramic Society, 22(13), 2261-2268. https://doi.org/10.1016/S0955-2219(02)00003-1

Sobolkina, A., Mechtcherine, V., Khavrus, V., Maier, D., Mende, M., Ritschel, M., \& Leonhardt, A. (2012). Dispersion of carbon nanotubes and its influence on the mechanical properties of the cement matrix. Cement and Concrete Composites, 34(10), 1104-1113. https://doi.org/10.1016/j.cemconcomp.2012.07.008

Srivastava, D., Wei, C., \& Cho, K. (2003). Nanomechanics of carbon nanotubes and composites. Applied Mechanics Reviews, 56(2), 215-229.

https://doi.org/10.1115/1.1538625

Stepkowska, E. T. (2006). Simultaneous IR/TG study of calcium carbonate in two aged cement pastes. Journal of Thermal Analysis and Calorimetry, 84(1), 175-180. https://doi.org/10.1007/s10973-005-7179-5

Sumio Iijima. (1991). Helical microtubules of graphitic carbon. Nature, 354(07 November 1991), 56-58. https://doi.org/https://doi.org/10.1038/354056a0

Szleifer, I., \& Yerushalmi-Rozen, R. (2005). Polymers and carbon nanotubes Dimensionality, interactions and nanotechnology. Polymer, 46(19 SPEC. ISS.), 78037818. https://doi.org/10.1016/j.polymer.2005.05.104 
Tafesse, M., \& Kim, H. K. (2019). The role of carbon nanotube on hydration kinetics and shrinkage of cement composite. Composites Part B: Engineering, 169(September 2018), 55-64. https://doi.org/10.1016/j.compositesb.2019.04.004

Tamimi, A., Hassan, N. M., Fattah, K., \& Talachi, A. (2016). Performance of cementitious materials produced by incorporating surface treated multiwall carbon nanotubes and silica fume. Construction and Building Materials, 114, 934-945.

https://doi.org/10.1016/j.conbuildmat.2016.03.216

Tian, H., Kong, X., Su, T., \& Wang, D. (2019). Comparative study of two PCE superplasticizers with varied charge density in Portland cement and sulfoaluminate cement systems. Cement and Concrete Research, 115(October 2018), 43-58. https://doi.org/10.1016/j.cemconres.2018.10.003

Torabian Isfahani, F., Li, W., \& Redaelli, E. (2016). Dispersion of multi-walled carbon nanotubes and its effects on the properties of cement composites. Cement and Concrete Composites, 74, 154-163. https://doi.org/10.1016/j.cemconcomp.2016.09.007

Trtnik, G., Turk, G., Kav, F., \& Bokan, V. (2008). Cement and Concrete Research Possibilities of using the ultrasonic wave transmission method to estimate initial setting time of cement paste, 38, 1336-1342. https://doi.org/10.1016/j.cemconres.2008.08.003

Tyson, B. M., Abu Al-Rub, R. K., Yazdanbakhsh, A., \& Grasley, Z. (2011). Carbon nanotubes and carbon nanofibers for enhancing the mechanical properties of nanocomposite cementitious materials. Journal of Materials in Civil Engineering, 23(7), 1028-1035. https://doi.org/10.1061/(ASCE)MT.1943-5533.0000266

Vesmawala, G. R., Vaghela, A. R., Yadav, K. D., \& Patil, Y. (2020). Effectiveness of polycarboxylate as a dispersant of carbon nanotubes in concrete. Materials Today: Proceedings, (xxxx), 10-14. https://doi.org/10.1016/j.matpr.2020.01.102

Wang, B., Han, Y., \& Liu, S. (2013). Effect of highly dispersed carbon nanotubes on the flexural toughness of cement-based composites. Construction and Building Materials, 46, 8-12. https://doi.org/10.1016/j.conbuildmat.2013.04.014

Wang, B., Han, Y., Pan, B., \& Zhang, T. (2013). Mechanical and morphological properties of highly dispersed carbon nanotubes reinforced cement based materials. Journal Wuhan University of Technology, Materials Science Edition, 28(1), 82-87. https://doi.org/10.1007/s11595-013-0645-1

Wang, B., Zhang, Y., \& Ma, H. (2014). Porosity and pore size distribution measurement of cement/carbon nanofiber composites by $1 \mathrm{H}$ low field nuclear magnetic resonance. Journal Wuhan University of Technology, Materials Science Edition, 29(1), 82-88. https://doi.org/10.1007/s11595-014-0871-1

Wang, Q., Cui, X., Wang, J., Li, S., Lv, C., \& Dong, Y. (2017). Effect of fly ash on rheological properties of graphene oxide cement paste. Construction and Building Materials, 138, 35-44. https://doi.org/10.1016/j.conbuildmat.2017.01.126

Wang, S., Lim, J. L. G., \& Tan, K. H. (2020a). Performance of lightweight cementitious composite incorporating carbon nanofibers. Cement and Concrete Composites, 109(October 2019), 103561. https://doi.org/10.1016/j.cemconcomp.2020.103561

Wang, S., Lim, J. L. G., \& Tan, K. H. (2020b). Performance of lightweight cementitious 
composite incorporating carbon nanofibers. Cement and Concrete Composites, 109(February), 103561. https://doi.org/10.1016/j.cemconcomp.2020.103561

Wang, X., Zhang, J., Yang, Y., Shu, X., \& Ran, Q. (2018a). Effect of side chains in block polycarboxylate superplasticizers on early-age properties of cement paste. Journal of Thermal Analysis and Calorimetry, 133(3), 1439-1446. https://doi.org/10.1007/s10973018-7231-x

Wang, X., Zhang, J., Yang, Y., Shu, X., \& Ran, Q. (2018b). Effect of side chains in block polycarboxylate superplasticizers on early-age properties of cement paste. Journal of Thermal Analysis and Calorimetry, 133(3), 1439-1446. https://doi.org/10.1007/s10973018-7231-x

Winnefeld, F., Becker, S., Pakusch, J., \& Götz, T. (2007). Effects of the molecular architecture of comb-shaped superplasticizers on their performance in cementitious systems. Cement and Concrete Composites, 29(4), 251-262.

https://doi.org/10.1016/j.cemconcomp.2006.12.006

$\mathrm{Xu}$, B., \& Li, Z. (2014). Paraffin/diatomite/multi-wall carbon nanotubes composite phase change material tailor-made for thermal energy storage cement-based composites. Energy, 72, 371-380. https://doi.org/10.1016/j.energy.2014.05.049

$\mathrm{Xu}, \mathrm{S}$., Liu, J., \& Li, Q. (2015). Mechanical properties and microstructure of multi-walled carbon nanotube-reinforced cement paste. Construction and Building Materials, 76, 1623. https://doi.org/10.1016/j.conbuildmat.2014.11.049

Yakovlev, Grigorij, Keriené, J., Gailius, A., \& Girniené, I. (2006). Cement Based Foam Concrete Reinforced by Carbon Nanotubes. Materials Science, 12(2), 147-151.

Yakovlev, Grigory, Pervushin, G., Maeva, I., Keriene, J., Pudov, I., Shaybadullina, A., ... Senkov, S. (2013). Modification of construction materials with multi-walled carbon nanotubes. Procedia Engineering, 57, 407-413.

https://doi.org/10.1016/j.proeng.2013.04.053

Yang, L., Yilmaz, E., Li, J., Liu, H., \& Jiang, H. (2018). Effect of superplasticizer type and dosage on fluidity and strength behavior of cemented tailings backfill with different solid contents. Construction and Building Materials, 187, 290-298. https://doi.org/10.1016/j.conbuildmat.2018.07.155

Yang, X., Liu, J., Li, H., Xu, L., Ren, Q., \& Li, L. (2019). Effect of triethanolamine hydrochloride on the performance of cement paste. Construction and Building Materials, 200, 218-225. https://doi.org/10.1016/j.conbuildmat.2018.12.124

Yazdanbakhsh, A., Grasley, Z., Tyson, B., \& Abu Al-Rub, R. (2012). Challenges and benefits of utilizing carbon nanofilaments in cementitious materials. Journal of Nanomaterials, 2012. https://doi.org/10.1155/2012/371927

Yu, J., Grossiord, N., Koning, C. E., \& Loos, J. (2007). Controlling the dispersion of multiwall carbon nanotubes in aqueous surfactant solution. Carbon, 45(3), 618-623. https://doi.org/10.1016/j.carbon.2006.10.010

Yu, X. G., Luo, S. S., Gao, Y. N., Wang, H. F., Li, Y. X., Wei, Y. R., \& Wang, X. J. (2010). Pore Structure and Microstructure of Foam Concrete. Advanced Materials Research, 177, 530-532. https://doi.org/10.4028/www.scientific.net/AMR.177.530 
Yurekli, K., Mitchell, C. A., \& Krishnamoorti, R. (2004). Small-angle neutron scattering from surfactant-assisted aqueous dispersions of carbon nanotubes. Journal of the American Chemical Society, 126(32), 9902-9903. https://doi.org/10.1021/ja047451u

Zhang, J., \& Liu, X. (2019). Research on the influence of carbon nanotubes (CNTs) on compressive strength and air-void structure of ultra-light foamed concrete. Mechanics of Advanced Materials and Structures, 26(24), 2009-2016.

https://doi.org/10.1080/15376494.2018.1475583

Zhang, L., Catalan, L. J. J., Larsen, A. C., \& Kinrade, S. D. (2008). Effects of sucrose and sorbitol on cement-based stabilization/solidification of toxic metal waste. Journal of Hazardous Materials, 151(2-3), 490-498. https://doi.org/10.1016/j.jhazmat.2007.06.022

Zhang, Y. R., Kong, X. M., Lu, Z. B., Lu, Z. C., \& Hou, S. S. (2015). Effects of the charge characteristics of polycarboxylate superplasticizers on the adsorption and the retardation in cement pastes. Cement and Concrete Research, 67, 184-196. https://doi.org/10.1016/j.cemconres.2014.10.004

Zhou, Q., \& Glasser, F. P. (2001). Thermal stability and decomposition mechanisms of ettringite at $<120^{\circ} \mathrm{C}$. Cement and Concrete Research, 31(9), 1333-1339. https://doi.org/10.1016/S0008-8846(01)00558-0

Zingg, A., Winnefeld, F., Holzer, L., Pakusch, J., Becker, S., Figi, R., \& Gauckler, L. (2009). Interaction of polycarboxylate-based superplasticizers with cements containing different C3A amounts. Cement and Concrete Composites, 31(3), 153-162. https://doi.org/10.1016/j.cemconcomp.2009.01.005

Zingg, A., Winnefeld, F., Holzer, L., Pakusch, J., Becker, S., \& Gauckler, L. (2008). Adsorption of polyelectrolytes and its influence on the rheology, zeta potential, and microstructure of various cement and hydrate phases. Journal of Colloid and Interface Science, 323(2), 301-312. https://doi.org/10.1016/j.jcis.2008.04.052

Zou, B., Chen, S. J., Korayem, A. H., Collins, F., Wang, C. M., \& Duan, W. H. (2015). Effect of ultrasonication energy on engineering properties of carbon nanotube reinforced cement pastes. Carbon, 85, 212-220. https://doi.org/10.1016/j.carbon.2014.12.094

Ушеров-Маршак, О. (2005). Химичесекие и минеральные добавки в бетон. Харьков. 



\section{Autoriaus mokslinių publikacijų disertacijos tema sąrašas}

\section{Straipsniai recenzuojamuose mokslo žurnaluose}

Leonavičius, D.; Pundienė, I.; Pranckevičienė, J.; Kligys, M. 2020. Selection of superplasticisers for improving the rheological and mechanical properties of cement paste with CNTs, Construction and building materials, Oxford: Elsevier Ltd 253: 19-22. ISSN 0950-0618.

Leonavičius, D.; Pundienè, I.; Pranckevičienè, J.; Girskas, G.; Kligys, M. 2019. The effect of the electrical conductivity of superplasticizers on the fluidity and early hydration parameters of cement paste, Ceramics-Silikáty. Prague: University of Chemistry and Technology 63(4): 390-398. ISSN 0862-5468. eISSN 18045847.

Leonavičius, D.; Pundienė, I.; Girskas, G.; Pranckevičienė, J.; Kligys, M.; Kairyte, A. 2018. The effect of multi-walled carbon nanotubes on the rheological properties and hydration process of cement pastes, Construction and building materials, Oxford: Elsevier Science Ltd 189(20): 947-954. ISSN 0950-0618. eISSN 1879-0526.2018. 


\section{Straipsniai kituose leidiniuose}

Leonavičius, D.; Pundienė, I.; Girskas, G.; Pranckevičienè, J.; Kligys, M.; Sinica, M. 2017. The influence of carbon nanotubes on the properties of water solutions and fresh cement pastes. IOP Conference Series: Materials Science and Engineering, 3rd International Conference on Innovative Materials, Structures and Technologies (IMST 2017) 251: 1-8. ISSN 1757-8981.

Leonavičius, D.; Pundienè, I.; Pranckevičienè, J.; Kligys, M. 2019. The impact of expanded polystyrene waste of different fineness on the properties of lightweight composite. IOP conference series: Materials science and engineering: 4th international conference on Innovative Materials, Structures and Technologies (IMST 2019) 660: 1-7. ISSN 1757-8981. eISSN 1757-899X.

Leonavičius, D.; Pundienè, I.; Kligys, M.; Pranckevičienè, J. 2019. The Lightweight Porous Fine Aggregate Composite Based on Secondary Raw Materials. Key engineering materials. Modern Materials and Manufacturing (MMM 2019) 799: 153-158 . ISSN 1013-9826.

Šukys, R.; Pranckevičienè, J.; Girskas, G.; Pundienė, I.; Leonavičius, D.; Kligys, M. 2019. Experimental study of behavior of cement pastes in the presence of carbon nanotubes. The 13th international conference "Modern building materials, structures and techniques”. 175-179. eISBN 9786094761973. eISSN 2029-9915. 


\section{Summary in English}

\section{Introduction}

\section{Formulation of the problem}

Expanded polystyrene waste is hydrophobic and light (density $12-20 \mathrm{~kg} / \mathrm{m}^{3}$ ), unevenly distributed in the volume of the cement matrix and poorly adheres to the cement matrix. Composites based on these wastes are characterized by heterogeneity and low compressive strength values.

Air-entraining additives that reduce the hydrophobicity of the waste and improve the distribution in the cement paste achieve an even distribution of the foam polystyrene waste in the cement paste. Air-entraining additives can be used, reducing waste hydrophobicity and improving distribution in the cement paste. Nano additives and effective SPs can be used to improve the adhesion of expanded polystyrene waste with cement stone and increase the cement stone's mechanical properties, but it is not clear how the combination of these additives can affect the structure and properties of a composite.

\section{Relevance of thesis}

Expanded polystyrene products are widely used as packaging, insulation, and others, but once used, all these products are disposed of and become waste. $95 \%$ of expanded polystyrene is air, so the constantly growing amounts of these waste in landfills occupy large areas and volumes and practically do not decompose. Mechanical milling of expanded polystyrene boards generates another type of expanded polystyrene waste (PPN) collected in filters. The possibilities for recycling or reusing expanded polystyrene packaging waste 
and PPN waste are promising but have not been sufficiently explored so far. One such possibility is to crush expanded polystyrene packaging waste and use the obtained granules PPT, together with technological waste PPN, to create cement composites.

Most of the research carried out so far on the use of expanded polystyrene waste in construction materials has been aimed at solving the problems of expanded polystyrene waste utilization. The investigated composite materials were characterized by low strength, so their field of application is very narrow. The broader application of such composite materials requires an expansion of the field of application, which requires an improvement in the properties of the composite itself.

Therefore, in this work, the use of both wastes for the development of lightweight cement composites is associated not only with the completion of the waste life cycle but also with the improvement of composite properties, i.e. by changing the ratio of aggregates to obtain composites of different properties (as structural or separately as an insulation material for low-rise buildings). The properties of the developed composite is analogous or better than of aerated concrete products.

For this purpose, it is planned to use effective additives that modify the composite structure, including nano-sized.

\section{Object of thesis}

The object of the thesis is a lightweight cement composite consisting of mixed waste aggregate and cement stone modified by multiwalled carbon nanotubes (MWCNTs), plasticizers and air-entraining admixture (OIP).

\section{Aim of thesis}

To create a lightweight cementitious composite with expanded polystyrene crushed and milled aggregate waste, using efficient chemical admixtures for concrete, nano and other additives.

\section{Tasks of thesis}

The following tasks need to be solved to achieve the goal of the work:

1. To determine the effect of the amount of MWCNTs additive on the structure and mechanical properties of cement stone, and to select the number of MWCNTs ensuring the best mechanical properties and structure based on the obtained results.

2. To investigate the effect of MWCNTs and different chemical admixtures on rheological properties of cement pastes, hydration of cement and physical-mechanical properties and structure of hardened cement stone and to select chemical admixtures that provide the best mechanical properties and structure

3. To investigate the effect of air-entraining admixture OIP and MWCNTs on a cement stone's physical-mechanical properties and structure. To find out the peculiarities of the action of cement matrix modifying additives on cement paste. 
4. To create a cement composite from a modified by MWCNTs and chemical admixture cement matrix with lightweight crushed and milled expanded polystyrene aggregates and investigate the developed composite's structure and properties.

\section{Research methodology}

Conductometry, $\mathrm{pH}$, dynamic viscosity, setting time and ultrasonic analysis methods were used for MWCNTs, chemical concrete admixture solutions and cement pastes. The cement paste's exothermic effect's temperature measurements were performed according to the methodology developed by Alcoa. Methods of scanning electron microscopy (SEM), radiographic, thermal analysis, porometry and ultrasonic analysis were used to investigate the structure of cement stone. The physical-mechanical properties of cement stone and lightweight composite were investigated by standard research methods to determine density, flexural strength, compressive strength, thermal conductivity, capillary water absorption, long-term water absorption, water vapour permeability and drying shrinkage. Methods of logical analysis and synthesis were used to evaluate the experimental data. The analysis of the obtained experimental data was performed using mathematical statistical methods, during which the deviations of the obtained values were evaluated.

\section{Scientific novelty of the thesis}

During the preparation of the thesis, the following novel results for the science of material engineering are obtained:

1. The content of MWCNTs $(0.005 \%$ from cement $)$ additive that most increases the compressive strength of cement stone was determined. The effect of MWCNTs mixture and SP on the hydration of the cement, the process of new formation and the formation of the cement stone structure was determined. The new knowledge allows the creation of cement stone with $25 \%$ better mechanical properties, than cement stone without MWCNTs.

2. It has been found that because of MWCNTs, concrete plasticizers blend (polyacrylate and polycarboxylate) and air-entraining admixtures interaction in cement paste changes the porous structure of the cement stone, increases the compressive strength and decreases the density. New knowledge allows creating a lower density lightweight composite without losing its strength properties.

3. Cement matrix modified by MWCNTs, concrete plasticizers blend (polyacrylate and polycarboxylate) and an air-entraining admixtures improves the physicalmechanical properties of lightweight composite with expanded polystyrene waste. In the compositions with the addition of MWCNTs $(0.005 \%$ of the cement content), the obtained density values are from 7 to $21 \%$ lower and the strength values from 3 to $33 \%$ higher than in analogous composites without the MWCNTs.

4. Crushed and milled expanded polystyrene waste ratio 2/2, and MWCNTs in composite allows to achieve analogous or better physical and mechanical properties than aerated concrete, when the density of the composite reaches $420 \mathrm{~kg} / \mathrm{m}^{3}$ and the compressive strength is $3.2 \mathrm{MPa}$. 
5. New positive effect knowledge of MWCNTs, composite with a concrete plasticizers blend and an air-entraining admixtures for physical-mechanical properties, allows creating light and very light cementitious composites with improved properties.

\section{Practical value of research findings}

In the production of light composite using crushed expanded polystyrene and milled expanded polystyrene, the problem of reuse of a large amount of this waste is solved, according to the principles of the circular economy.

The use of both wastes for the development of lightweight cementitious composites is associated not only with the completion of the waste life cycle but also with the development of new, less energy-intensive building composites, their properties improvement and more usage possibilities in construction building materials (e.g. expanded clay-based, or autoclaved aerated concrete). The properties of the developed composite is analogous or better than that of aerated concrete products, therefore the developed composite can be used as an alternative to autoclaved aerated concrete.

The lightweight composite can be used in low buildings' external and internal walls as an element of a load-bearing frame or as heating material, also in the construction of high buildings as partitions in the existing reinforced concrete frame.

The properties of this lightweight composite can be easily adjusted during production. That creates a unique opportunity to design outdoor partitions from one solid material when products with higher compressive strength are used together with elements with lower strength values but better thermal insulation properties.

\section{Defended statements}

1. MWCNTs $(0,005 \%$ from cement), together with a blend of polyacrylate and polycarboxylate plasticizers, positively affect cement hydration, increase the number of hydration products, and increase the compressive strength of cement stone.

2. In interaction with the blend of polyacrylates and polycarboxylates plasticizers and the air-entraining admixture, MWCNTs change the cement stone structure and improve the cement stone's mechanical properties increasing the open porosity of the material.

3. The addition of MWCNTs allows to achieve higher compressive strength and lower density values in composites with crushed and milled expanded polystyrene waste fillers compared to analogous composites without the MWCNTs. The performance of the developed composite is analogous or better than autoclaved aerated concrete

\section{Approval of the research findings}

Seven scientific articles were published on the topic of the thesis: three - in the scientific journal included in Clarivate Analytics Web of Science database (Leonavičius et al., 2020, Leonavičius et al., 2019c, Leonavičius et al., 2018); one - in Clarivate Analytics Web of Science database "Conference Proceedings" (Leonavičius et al., 2017); two - in scientific journals of international databases (Leonavičius et al., 2019d, Leonavičius et al., 2019a), one - in another international journal (Leonavičius et al., 2019b). 
The results of the conducted research are presented in 4 national and international scientific conferences:

- International Conference "Modern Materials and Manufacturing 2019" (MMM 2019), 2019, Tallinn;

- International Conference "Innovative Materials, Structures and Technologies 2019”, (IMST 2019), 2019, Riga;

- International Conference $13^{\text {th }}$ International Conference, "Modern Building Materials, Structures and Techniques", (MBMST 2019) 2019, Vilnius;

- International Conference "Innovative Materials, Structures and Technologies 2017”, (IMST 2017), 2017, Riga;

- $23^{\text {th }}$ Young Scientists Conference "Science - Future of Lithuania“" 2016, Vilnius.

\section{Structure of the dissertation}

The thesis consists of introduction, three chapters and general conclusions.

The work consists of 151 pages excluding annexes and summary, 3 numbered equations, 67 figures, 14 tables and 196 references.

\section{Research analysis of composite materials with multi-walled carbon nano tubes, chemical additives and expanded polystyrene waste}

An analysis of the literature shows that the addition of MWCNTs significantly affects the rheological properties of cementitious composites and the hardened composite. The optimal amount of MWCNTs in a composite depends on many factors, such as chemical admixtures types, fineness of the fillers. SP has a different molecular structure and their adsorption on the surface of cement particles has different effects on the hydration of cement minerals and the properties of hardened samples. The air-entraining admixtures are used to adhere the lightweight composite cement matrix to lightweight aggregates and at the same time reduce the density. However, there is no detailed information in the literature on the overall interaction of MWCNTs, SP and air- entraining admixtures in cement paste. Studies on very light composites $\left(300-500 \mathrm{~kg} / \mathrm{m}^{3}\right)$ are insufficient, although the potential for use is enormous because of the significant amount of PP waste. When developing a lightweight composite and achieving lower density and thermal conductivity without losing strength, it is essential to reduce the $\mathrm{W} / \mathrm{C}$ ratio, use nano additives and chemical admixtures and select the ratio of coarse to fine lightweight aggregates to fill the air gaps to ensure good performance of the composite.

\section{Materials used for the composite and research methods}

The following materials were used in the work: CEM I 42.5R Portland cement (PC), milled sand (MS), metakaolin (MK), SP based on lignosulphonates (SP (A)), SP based on polyacrylates (SP (B)), SP based on polycarboxylates (SP (C)), air entrainer Ufapore TCO (OIP), crushed PP waste $0.5-5 \mathrm{~mm}$ fraction (PPT), milled PP waste $0.18-4 \mathrm{~mm}$ fraction (PPN) and multiwalled carbon nanotubes (MWCNTs) in the form of GRAPHISTRENGTH CW2-45 bundles (Arkema, France). The bundles of MWCNTs contain 
$45 \%$ carbon nanotubes and $55 \%$ carboxymethylcellulose. MWCNTs must be properly prepared before use. The bundles are swollen in distilled water at $90-100{ }^{\circ} \mathrm{C}$ for $10 \mathrm{~min}$ and dispersed with UZDN-2T disperser, frequency $22 \mathrm{kHz}, 480 \mathrm{~W}$ for $5 \mathrm{~min}$.

Table S2.1. Compositions of samples with multi-walled carbon nano tubes, mass \%

\begin{tabular}{|l|l|l|l|l|}
\hline \multirow{2}{*}{ Composition } & \multicolumn{2}{|l|}{ Components, mass \% } & \multirow{2}{*}{ W/C } \\
\cline { 2 - 4 } & \multirow{2}{*}{ PC } & Graphistrength CW2-45 & \\
\cline { 2 - 4 } & & Bundles & MWCNTs & \\
\hline $\mathrm{T}-0$ & 100 & 0 & 0 & 0.3 \\
\hline $\mathrm{T}-0.00005$ & 99.99994 & 0.000061 & 0.00005 & 0.3 \\
\hline $\mathrm{T}-0.0005$ & 99.99939 & 0.000611 & 0.0005 & 0.3 \\
\hline $\mathrm{T}-0.005$ & 99.99389 & 0.006111 & 0.005 & 0.3 \\
\hline $\mathrm{T}-0.05$ & 99.93889 & 0.061111 & 0.05 & 0.3 \\
\hline $\mathrm{T}-0.5$ & 99.38889 & 0.611111 & 0.5 & 0.3 \\
\hline
\end{tabular}

Six compositions were made to evaluate the effect of the amount of MWCNTs admixture used on PC paste and hardened stone properties (Table S2.1).

For the study of the effect of SP admixtures and MWCNTs on the properties of PC samples, ten compositions were made (Table S2.2). The exact amount of MWCNTs and SP admixtures was selected for half of the compositions, with a constant W/C ratio, and the $\mathrm{W} / \mathrm{C}$ was reduced for the other half to ensure uniform spreading.

Table S2.2. Composition of cement samples with plasticizers and multi-walled carbon nano tubes, mass \%

\begin{tabular}{|l|l|l|l|l|l|l|}
\hline Composition & PC & SP(A)* & SP(B)* & SP(C)* & MWCNTs* & W/C \\
\hline NK & 100 & & & & 0.005 & 0.3 \\
\hline NA & 100 & 0.2 & & & 0.005 & 0.3 \\
\hline NB & 100 & & 0.2 & & 0.005 & 0.3 \\
\hline NC & 100 & & & 0.2 & 0.005 & 0.3 \\
\hline N(B+C) & 100 & & 0.1 & 0.1 & 0.005 & 0.3 \\
\hline WN & 100 & & & & 0.005 & 0.29 \\
\hline WNA & 100 & 0.2 & & & 0.005 & 0.28 \\
\hline WNB & 100 & & 0.2 & & 0.005 & 0.25 \\
\hline WNC & 100 & & & 0.2 & 0.005 & 0.25 \\
\hline WN(B+C) & 100 & & 0.1 & 0.1 & 0.005 & 0.23 \\
\hline
\end{tabular}

* over $100 \%$ of dry component 
To evaluate the effect of MWCNTs content and OIP on the properties of PC samples with selected SP blend $(0.1 \% \mathrm{SP}(\mathrm{B})+0.1 \% \mathrm{SP}(\mathrm{C}))$, five compositions were made (Table S2.3).

Table S2.3. Composition of cement samples with plasticizers mix, air-entraining and multi-walled carbon nano tubes, mass \%

\begin{tabular}{|l|l|l|l|l|l|}
\hline Composition & PC & MWCNTs * & SP $(\mathrm{B}+\mathrm{C}) *$ & OIP* & W/C \\
\hline M-0SA & 100 & 0 & 0.2 & 0.03 & 0.26 \\
\hline M-1SA & 100 & 0.00005 & 0.2 & 0.03 & 0.26 \\
\hline M-2SA & 100 & 0.0005 & 0.2 & 0.03 & 0.36 \\
\hline M-3SA & 100 & 0.005 & 0.2 & 0.03 & 0.26 \\
\hline M-4SA & 100 & 0.05 & 0.2 & 0.03 & 0.26 \\
\hline M-5SA & 100 & 0.5 & 0.2 & 0.03 & 0.26 \\
\hline
\end{tabular}

* over $100 \%$ of dry component

Ten compositions were made to determine the structure and properties of the composite, with a matrix modified by MWCNTs and chemical (Table S2.4). The ratio of PPT to PPN in the compositions varied from 0 to 4 . The first five compositions are without MWCNTs, the others with the same amount of $0.005 \%$ (from PC) MWCNTs.

Table S2.4. Composite material compositions, mass \%

\begin{tabular}{|c|c|c|c|c|c|c|c|c|c|c|}
\hline \multirow{2}{*}{$\begin{array}{l}\text { Com- } \\
\text { posi- } \\
\text { tion }\end{array}$} & \multicolumn{5}{|c|}{ Mass \% } & \multirow{2}{*}{$\begin{array}{l}\mathrm{PPT} / \\
\mathrm{PPN}\end{array}$} & \multirow{2}{*}{$\begin{array}{l}\mathrm{SP} \\
(\mathrm{B}+\mathrm{C})^{*}\end{array}$} & \multirow{2}{*}{ OIP* } & \multirow{2}{*}{$\begin{array}{l}\text { MWC } \\
\text { NTs* }\end{array}$} & \multirow{2}{*}{$\mathrm{W} / \mathrm{C}$} \\
\hline & PC & MK & Sand & PPT & PPN & & & & & \\
\hline K1 & 49 & 16.5 & 29.5 & - & 5.0 & $0 / 4$ & 0.2 & 0.025 & - & 0.714 \\
\hline K2 & 49 & 16.5 & 29.5 & 1.25 & 3.75 & $1 / 3$ & 0.2 & 0.025 & - & 0.714 \\
\hline K3 & 49 & 16.5 & 29.5 & 2.5 & 2.5 & $2 / 2$ & 0.2 & 0.025 & - & 0.714 \\
\hline K4 & 49 & 16.5 & 29.5 & 3.75 & 1.25 & $3 / 1$ & 0.2 & 0.025 & - & 0.714 \\
\hline K5 & 49 & 16.5 & 29.5 & 5.0 & - & $4 / 0$ & 0.2 & 0.025 & - & 0.714 \\
\hline $\mathrm{K} 1 \mathrm{C}$ & 49 & 16.5 & 29.5 & - & 5 & $0 / 4$ & 0.2 & 0.025 & 0.005 & 0.714 \\
\hline $\mathrm{K} 2 \mathrm{C}$ & 49 & 16.5 & 29.5 & 1.25 & 3.75 & $1 / 3$ & 0.2 & 0.025 & 0.005 & 0.714 \\
\hline $\mathrm{K} 3 \mathrm{C}$ & 49 & 16.5 & 29.5 & 2.5 & 2.5 & $2 / 2$ & 0.2 & 0.025 & 0.005 & 0.714 \\
\hline $\mathrm{K} 4 \mathrm{C}$ & 49 & 16.5 & 29.5 & 3.75 & 1.25 & $3 / 1$ & 0.2 & 0.025 & 0.005 & 0.714 \\
\hline $\mathrm{K} 5 \mathrm{C}$ & 49 & 16.5 & 29.5 & 5.0 & - & $4 / 0$ & 0.2 & 0.025 & 0.005 & 0.714 \\
\hline
\end{tabular}

* over $100 \%$ of dry component

Materials were mixed in a round bucket, with a vertical electric mixer on which the shaft impeller is placed. The speed was $125 \mathrm{rpm}$ during all mixing. The MWCNTs solution 
and OIP were mixed first for $5 \mathrm{~min}$, then SM, PC, MK and SP were added and mixed for another $5 \mathrm{~min}$. Then the necessary amount of PPN to the forming mixture is added, and mixing is continued. Finally, PPTs are added and mixed until a homogeneous mass is obtained. The prepared forming mixture was poured into the steel moulds and slightly compacted with a wooden board (so as not to damage the structure of aggregates).

The research of PC pastes and the EXO process was performed according to Alcoa's methodology. Compressive strength of PC stone specimens after 2, 7 and 28 days of hardening was determined according to the standard LST EN 196-1:2016. The viscosity and temperature of different concentrations of MWCNTs and SP solutions and PC pastes with MWCNTs, SP and OIP were measured with a vibroviscosimeter SV-10, measuring a limit up to $12000 \mathrm{mPa} \cdot \mathrm{s}$, accuracy $0.01 \mathrm{mPa} \cdot \mathrm{s}$. X-ray diffractometer DRON-7 was used for the study of hardened PC stone with MWCNTs and SP The ICDD database was used to decrypt the peaks. The open (capillary) porosity of hardened PC stone was calculated following LST EN 12087: 2013 standard. The density of the lightweight composite samples was determined following LST EN 1602.

The compressive strength of composite samples was determined in accordance with the standard LST EN 826: 2013 . The thermal conductivity $\left(\lambda_{10}\right)$ of the lightweight composite samples was determined using a LaserComp FOX 304 instrument. The measuring range of the device is $0.01-0.50 \mathrm{~W} /(\mathrm{m} \cdot \mathrm{K})$, the accuracy of measurements is about $1 \%$. The water vapour transmission properties of the samples were determined following LST EN 12086:2013. The values of drying shrinkage of lightweight composite samples were determined following LST EN 772-14: 2003.

\section{Research of cement paste, cement stone and lightweight composite with polystyrene foam waste, modified by multi-walled carbon nanotubes and chemical admixtures}

Changes in EXO reaction temperature over time reflects the hydration of PC pastes with MWCNTs (Fig. S3.1). The EXO temperature of the control sample T-0 was $87{ }^{\circ} \mathrm{C}$. The number of MWCNTs $(0.00005 \%$ and $0.5 \%)$ reduced the EXO temperature by four ${ }^{\circ} \mathrm{C}$ and $16^{\circ} \mathrm{C}(20 \%)$. MWCNTs slowed the initial hydration of the cement and prolonged the EXO temperature-time (up to 2.2 times).

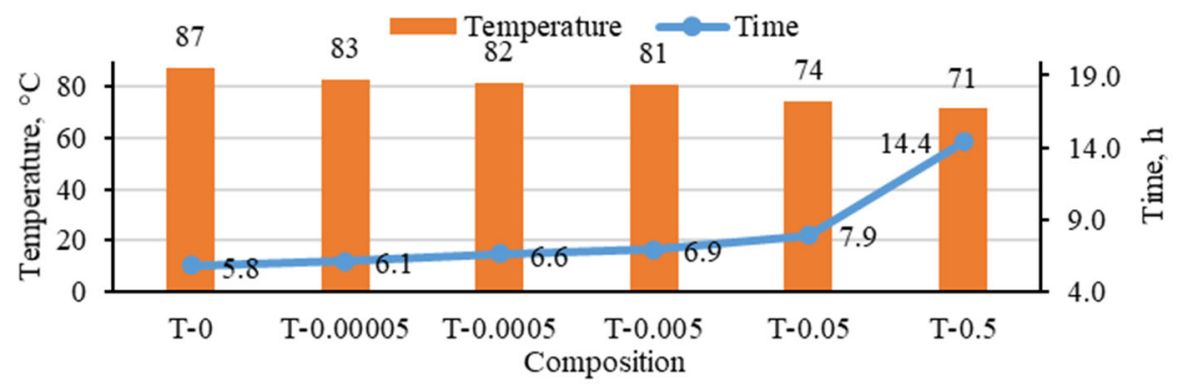

Fig. S3.1. Exothermic reaction temperatures depending on the amount of multi-walled carbon nano tubes 
The compressive strength of the control, T-0 sample, reached $61 \mathrm{MPa}$ after two days of hardening. It was found that after 2 days of hardening increasing the number of MWCNTs in the PC stone to $0.005 \%$ compared to the control, $\mathrm{T}-0$ sample, increases the strength of the samples by $7.3 \%$ (Fig. S3.2), and higher amounts of MWCNTs $0.05 \%$ and $0.5 \%$ reduce the compressive strength by $5 \%$ and $10 \%$. The same trends were observed after 7 and 28 days of hardening.

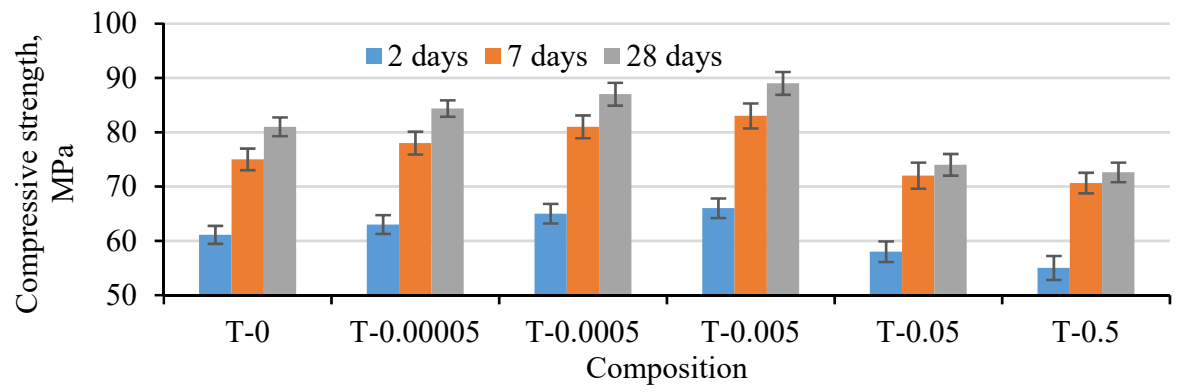

Fig. S3.2. Compressive strength of cement stone samples, depending on the amount of multiwalled carbon nano tubes

Researchers studying higher amounts of MWCNTs (up to 1\% of the amount of PC) (Konsta-Gdoutos 2010, Wang et al. 2013, Siddique and Mehta 2014) indicated that microcracks and agglomerates of MWCNTs were found in the structure of samples with higher levels of MWCNTs around PC grains. These agglomerates resulted in only partial hydration of the PC grains and weak bonds of the compounds formed during hydration. Our studies showed that when the number of MWCNTs in the sample exceeded $0.005 \%$, the value of compressive strength decreased.

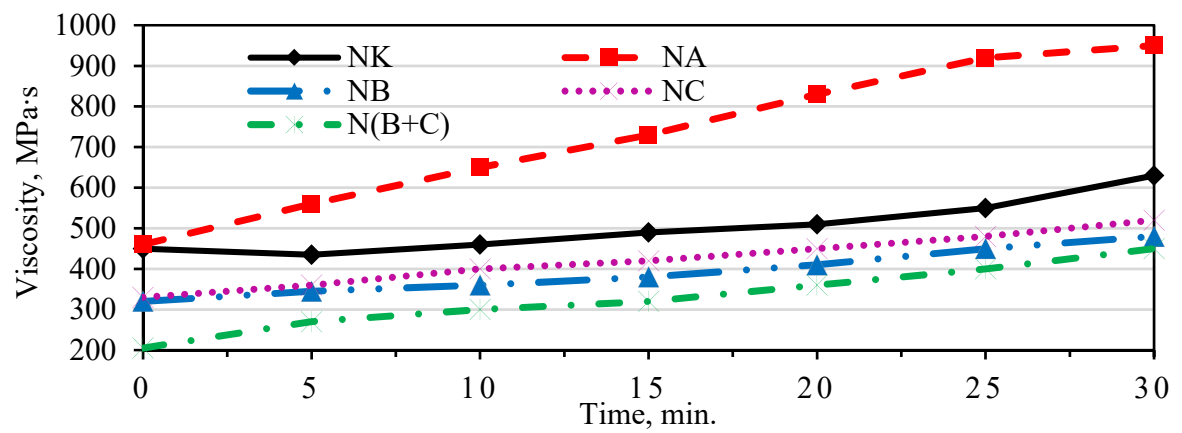

Fig. S3.3. Cement pastes with plasticizers and multi-walled carbon nano tubes viscosity changes

Measurements of the viscosity of PC pastes with constant amount MWCNTs $(0.005 \%)$ and SP were further performed. The initial viscosity of the PC pastes the most increased of the sample with SP (A), the least by the blend of SP (B+C) (Fig. S3.3). After $30 \mathrm{~min}$, the viscosity increased significantly only in NA paste with $\mathrm{SP}(\mathrm{A})$. The difference 
between control (NK) and NA pastes is $320 \mathrm{~Pa} \cdot \mathrm{s}$. Newly formed compounds in NA paste (ettringite and others) interact with agglomerates of MWCNTs as described (Liebscher, Lange, et al., 2017) and increase viscosity. Compared to the viscosity of (NK) paste, the viscosity of $\mathrm{N}(\mathrm{B}+\mathrm{C})$ paste decreased the most (about two times) in which the SP blend was used.

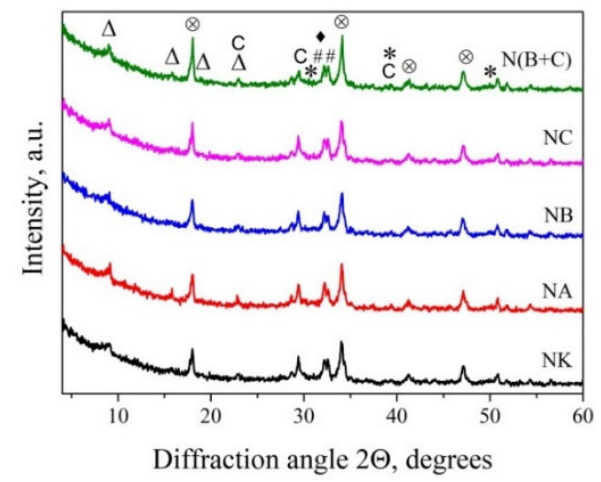

Fig. S3.4. Cement stone $\mathrm{X}$-Ray analysis. Key: $\Delta$ - ettringite, $\otimes$ - portlandite,

$$
\mathrm{C}-\text { calcite, } \#-\mathrm{C} 2 \mathrm{~S}, \bullet-\mathrm{C} 3 \mathrm{~S}, *-\mathrm{CSH}
$$

XRD determined the main products of PC hydration (Fig. S3.4) in all NK, NA, NB, $\mathrm{NC}$ and $\mathrm{N}(\mathrm{B}+\mathrm{C})$ samples after 28 days of hardening - ettringite, portlandite, monocarboaluminate, calcium silicate hydrate, calcite, belite, alite, however, the NA sample produces significantly more ettringite and slightly less portlandite compared to the rest of the $\mathrm{NK}, \mathrm{NB}, \mathrm{NC}$ and $\mathrm{N}(\mathrm{B}+\mathrm{C})$ samples.

It is known that in a sample with $\mathrm{SP}(\mathrm{A})$, its sulfonate groups and PC mineral sulfate ions react with the aluminate phase to form higher amounts of ettringite (Mikanovic \& Jolicoeur, 2008). Comparing the $\mathrm{NB}, \mathrm{NC}$ and $\mathrm{N}(\mathrm{B}+\mathrm{C})$ samples, it was observed that the differences between them are minor; only the peak of the portlandite of the N(B+C) sample, whose intensity is slightly higher, stands out.

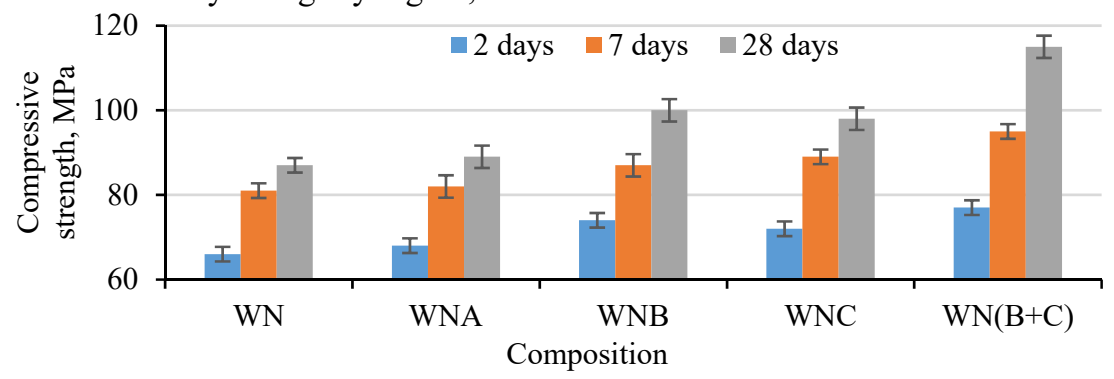

Fig. S3.5. Plasticizers and multi-walled carbon nano tubes impact to the compressive strength of specimens 
Specimens with the same spread values but appropriately different $\mathrm{w} / \mathrm{c}$ ratios were selected (compositions provided in Table S2.2) for the studies of the MWCNTs and SPs impact on the sample strength.

After 2 days of curing, tests showed that the reference specimen's compressive strength without plasticizer, WN, was characterized by the lowest compressive strength of $65 \mathrm{MPa}$ (Fig. S3.5). The highest growth in strength, of $16 \%$, was observed in samples with SP $(B+C)$ blend. Similarly, after 7 and 28 days of curing, the most significant growth in strength $(17.3 \%)$ was observed in the specimens with SP $(B+C)$ blend. The same trends for the SP's blend have been observed in other studies (Demidova-Buizinienè \& Pundienè, 2015; Plank et al., 2009).

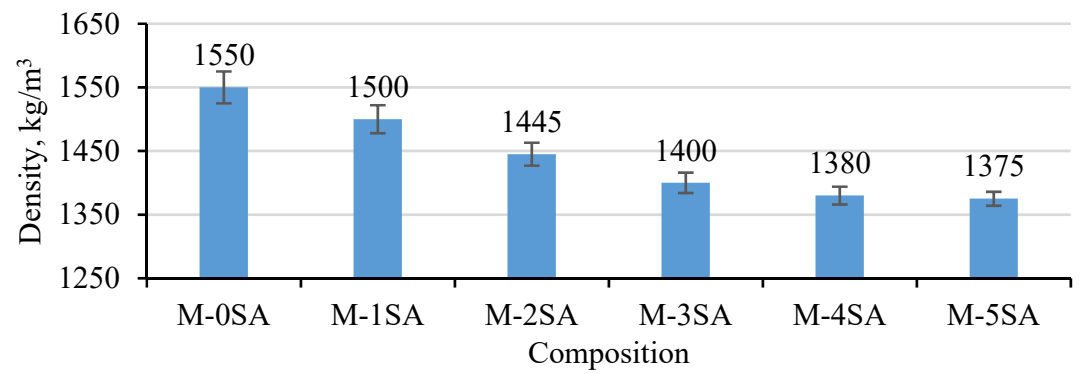

Fig. S3.6. Density of cement stone with plasticizers blend and air-entraining, depending on the amount of multi-walled carbon nano tubes

Increasing the MWCNTs content (from 0.00005 to $0.5 \%$ ) in the compositions decreases the density of the samples by $3.3 \%, 7.1 \%, 10.1 \%, 11.2 \%$ and $10.1 \%$, respectively, compared to the M-0SA sample (Fig. S3.6). Higher amounts of MWCNTs of 0.05 and $0.5 \%$ in interaction with OIP no longer reduce the density.

Open porosity studies (Fig. S3.7) show that due to the interaction of MWCNTs and OIP, increasing the number of MWCNTs increases the open porosity of the samples from $42.5 \%$ to $47 \%$. By increasing the number of MWCNTs, more air is added to the cement paste with OIP (Zhang and Liu 2019) and the structure of the sample's changes.

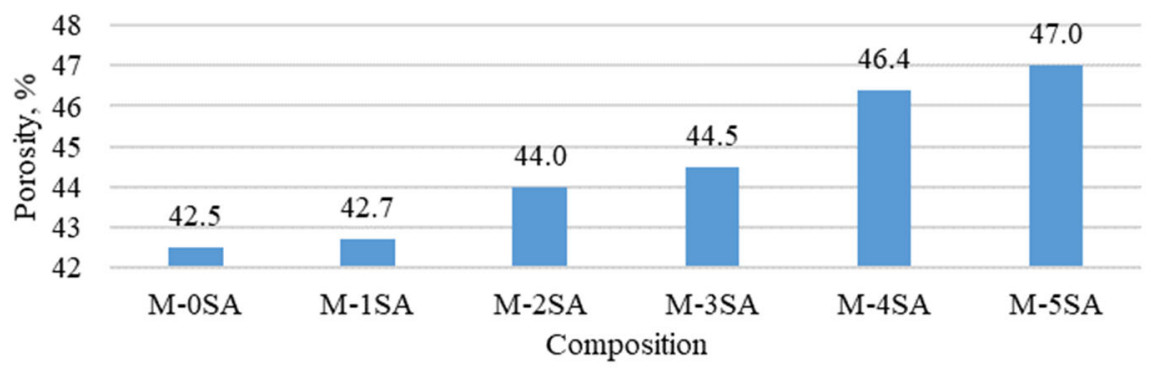

Fig. S3.7. Porosity of cement stone with plasticizers blend and air-entraining, depending on the amount of multi-walled carbon nano tubes 
The macrostructure of samples $\mathrm{M}-0 \mathrm{SA}$ is dominated by large pores of $150-250 \mu \mathrm{m}$ (Fig. S3.8 a), with very few pores smaller than $10 \mu \mathrm{m}$. In the M-3SA sample (Fig. S3.8 b), the structure changes, dominated by evenly distributed pores of 50-20 $\mu \mathrm{m}$.

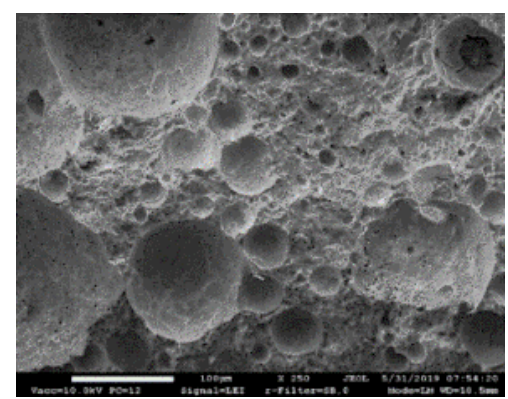

a)

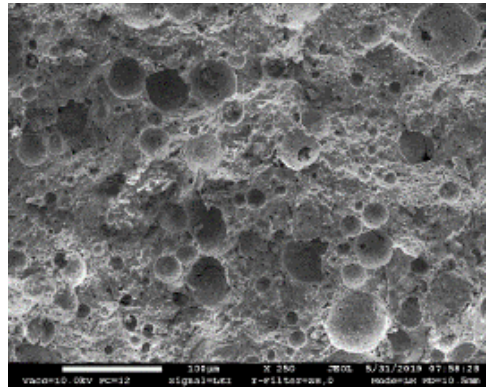

b)

Fig. S3.8. Macrostructure of cement stone with plasticizers blend and air-entraining, depending on the amount of multi-walled carbon nano tubes (magnification - $\times 250$ ): a) M-0SA, b) M-3SA

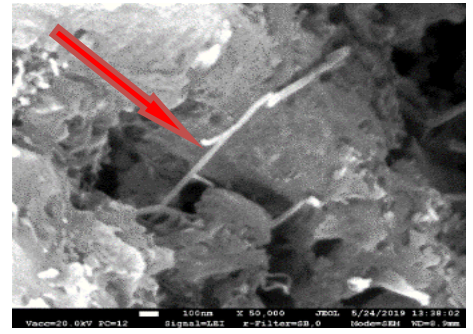

a)

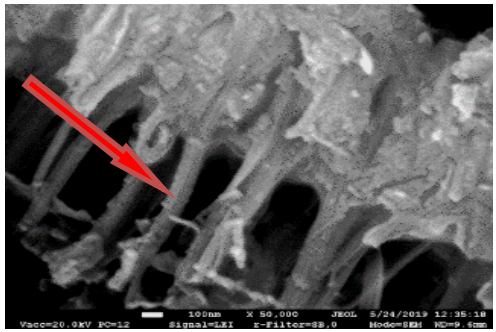

b)

Fig. S3.9. Microstructure of cement stone with plasticizers blend and air-entraining, depending on the amount of multi-walled carbon nano tubes: a) M-1SA, b) M-3SA

Single MWCNTs fibres are observed in sample $\mathrm{M}-1 \mathrm{SA}$ (Fig. S3.9 a). In the $\mathrm{M}-$ 3SA sample (Fig. S3.9 b), the MWCNTs, together with the cement hydration products, form a relatively regular reinforcing network in the entire volume of the pore. Such microstructure formation can also affect the strength values of the samples.

It is known that OIP admixture significantly reduces the density and strength of samples. After 2-28 days of hardening (Fig. S3.10), lower amounts of MWCNTs (up to $0.005 \%$ ) in interaction with OIP increase the compressive strength by 6 and $9 \%$, while higher (0.05 and $0.5 \%)$ MWCNTs reduce compressive strength values in the range of 3$12.8 \%$. Studies by other researches confirmed that only lower amounts of MWCNTs (up to $0.1 \%$ composition) increase the compressive strength of the samples (Zou et al., 2015). Our studies show that the interaction of all three OIPs, SPs, and MWCNTs form the pore structure and respond accordingly to the samples' strength properties. 


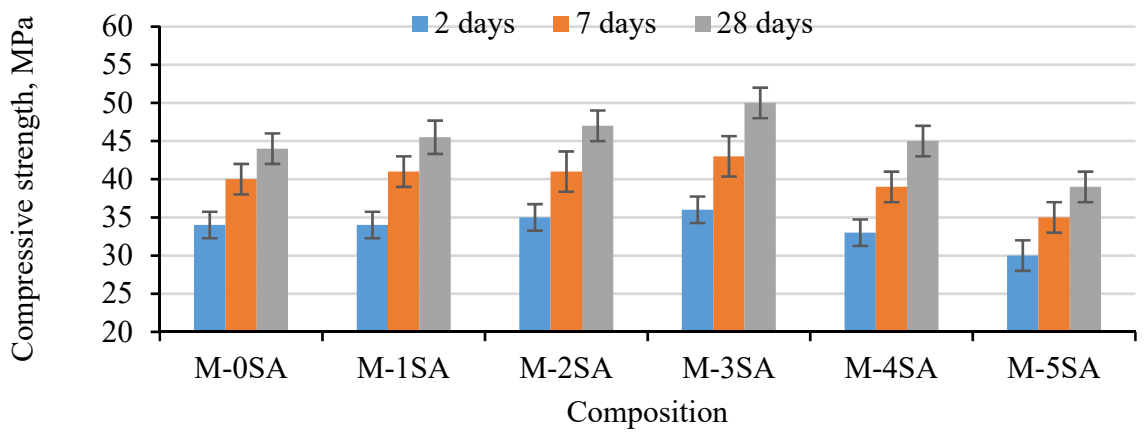

Fig. S3.10. Compressive strength of cement stone with plasticizers blend and air-entraining, depending on the amount of multi-walled carbon nano tubes

K3C sample with a PPT/PPN ratio of $2 / 2$ was selected for microstructure studies. We see that the contact zone between the PPN particle and the cement matrix is good (Fig. S3.11 a); the cement matrix fills all the cavities of the PPN particle. In the pores of the cement matrix, a large number of MWCNTs intertwined with the cement hydration products (Fig. S3.11 b), thus ensuring good mechanical properties of the composite.

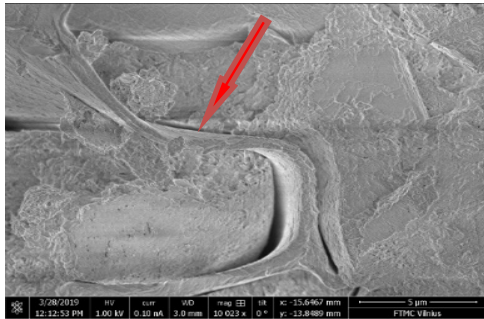

a)

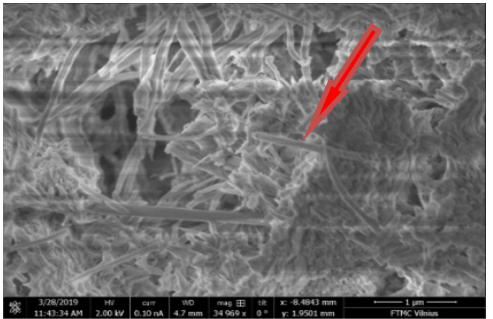

b)

Fig. S3.11. Microstructure of K3C composite: a) crushed waste and cement contact (magnification $-\times 10000)$; b) multi-walled carbon nano tubes in the cement pore (magnification $-\times 35000$ )

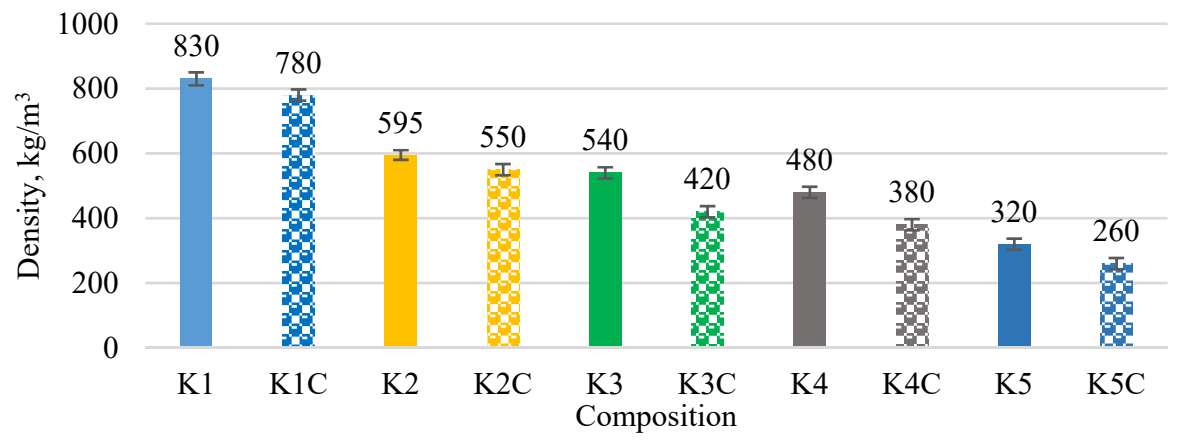

Fig. S3.12. The density of the lightweight composite 
As the PPT/PPN ratio varied in the composite, the density of hardened samples with MWCNTs additive (Fig. S3.12) decreased by 6, 8, 22, 21 and 19\%, i.e., from 780 to $260 \mathrm{~kg} / \mathrm{m}^{3}$. In the samples without MWCNTs, the density of the additive decreased from 830 to $320 \mathrm{~kg} / \mathrm{m}^{3}$. Most densities decreased in the samples $\mathrm{K} 3 \mathrm{C}$ and $\mathrm{K} 4 \mathrm{C}$, in which the PPT filler predominated from the voids formed due to the included air during mixing.

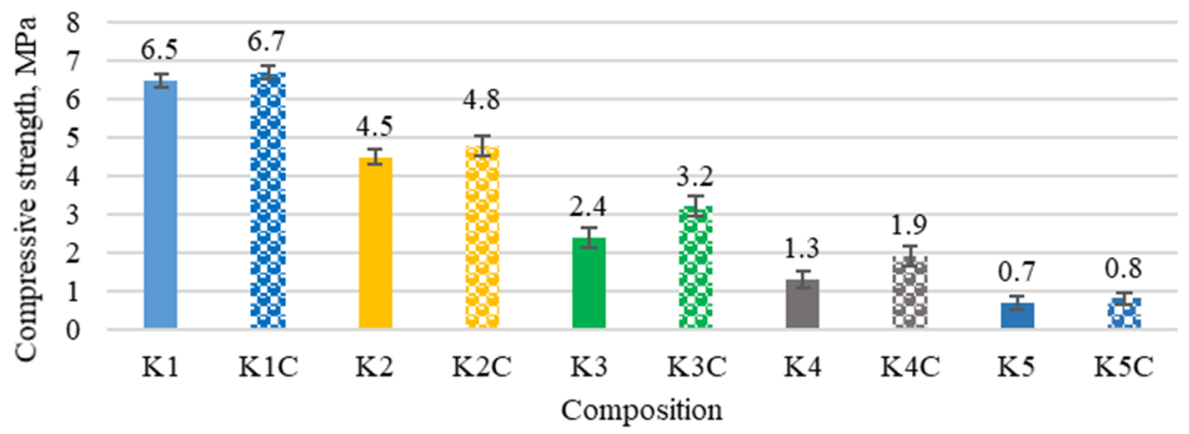

Fig. S3.13. Compressive strength of the lightweight composite

In the samples without the addition of MWCNTs, the maximum strength value after 28 days of curing was found in the K1 sample. With the change of PPT/PPN ratio from $0 / 4$ to $4 / 0$, the compressive strength of the samples decreased by $30,63,80$ and $89 \%$ compared to the K1 sample (Fig. S3.13). When the PPT/PPN ratio varied from $0 / 4$ to $4 / 0$, the compressive strength of the samples with MWCNTs increased by $3 \%, 7 \%, 33 \%, 46 \%$ and $14 \%$ compared to samples of similar composition without the addition of MWCNTs.

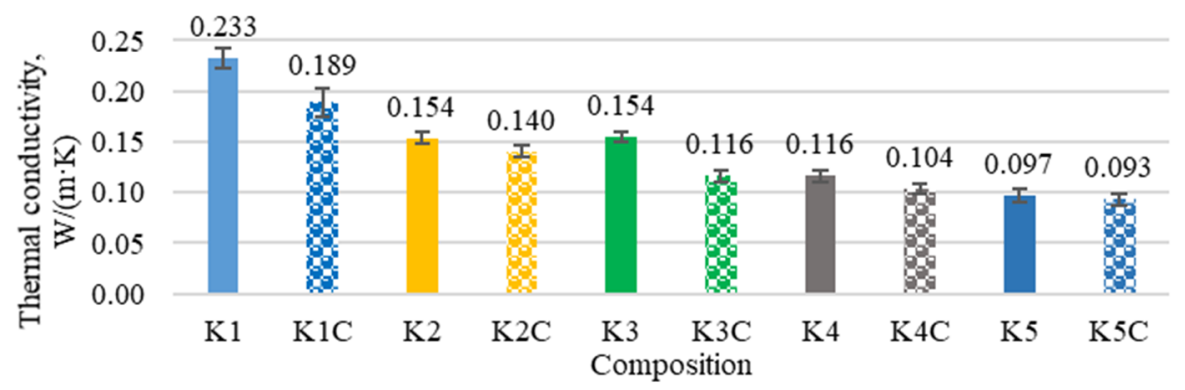

Fig. S3.15. Thermal conductivity of the composite

As the PPT content in the sample increased, the thermal conductivity coefficient's (TCC) value continuously decreased from 0.233 to $0.097 \mathrm{~W} /(\mathrm{m} \cdot \mathrm{K})$ (Fig. S3.15). The introduction of MWCNTs into the $\mathrm{K} 1 \mathrm{C}$ to $\mathrm{K} 5 \mathrm{C}$ samples decrease thermal conductivity by $18 \%, 9 \%, 25 \%, 11 \%$ and $4 \%$, the TCC, compared to similar compositions without MWCNTs. The interaction of MWCNTs with OIP (Xiao 2013, Xu and Li 2014), which increases the porosity of the samples, can contribute to better TCC of the samples. 


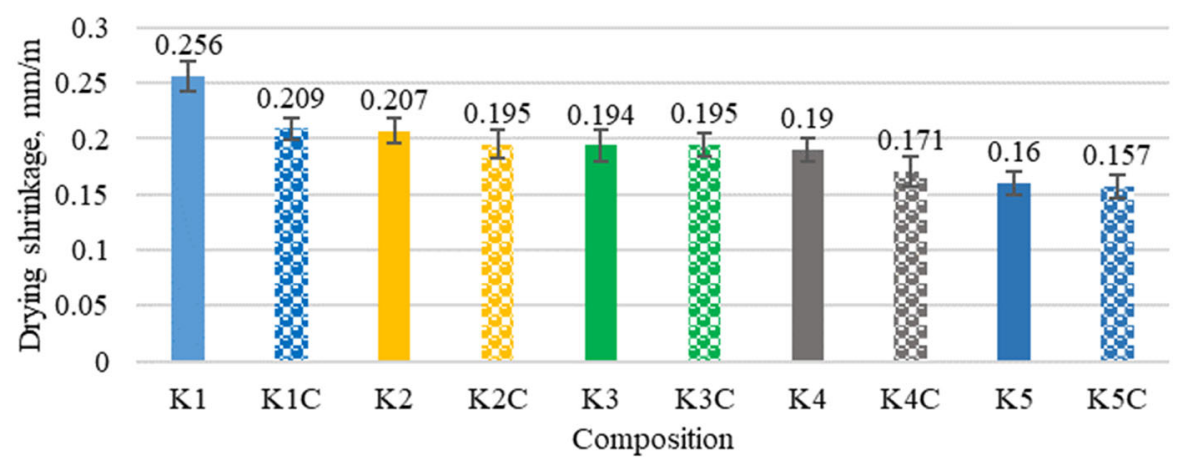

Fig. S3.16. Drying shrinkage of composite $\mathrm{mm} / \mathrm{m}$

Changing the PPT/PPN ratio of the samples reduced the drying shrinkage by $19 \%$, $24 \%, 25 \%$ and $37 \%$ compared to the K1 sample (Fig. S3.16). By adding CNT to the composite, drying shrinkage of the samples was reduced by $18 \%, 6 \%, 1 \%, 10 \%$, and $2 \%$, because MWCNTs fill cracks and pores, as shown by our microstructural studies, capillary and shrinkage stresses are weakened, thus preventing the cement stone from shrinking further.

\section{General conclusions}

1. The addition of MWCNTs in cement paste increased the start and end of setting time compared to the control sample. The most effective increase in the compressive strength of cement stone compared to the control sample after 2, 7 and 28 days of hardening is the amount of $0.005 \%$ MWCNTs, but $0.05 \%$ and $0.5 \%$ MWCNTs decrease the compressive strength of samples.

2. The viscosity of cement pastes with the optimal content of $0.005 \%$ MWCNTs among the investigated SPs (based on lignosulfonates, polyacrylates and polycarboxylates, and a blend of polyacrylate and polycarboxylate) was most effectively reduced by a blend of SP consisting of polyacrylate and polycarboxylate blend (rate 1:1). The viscosity of cement paste with SP blend was up to 2.5 times lower compared to other tested SPs, which allows to reduce $\mathrm{W} / \mathrm{C}$ ratio.

3. Compared to control, samples with $0.005 \%$ MWCNTs additive, polyacrylatebased and polycarboxylate-based SP increase EXO reaction time by $0.8 \mathrm{~h}$, without changing the maximum temperature of the exothermic reaction.

4. X-ray and thermographic examinations, performed after 28 days of hardening show that the control and samples with MWCNTs and SP had a similar mineral composition, but in samples with lignosulphonate-based SP more ettringite was formed. Due to the interaction of MWCNTs and SP mixture, most hydration products are formed, so the weight loss in the sample is (10-20\%) higher than in the control and samples with individual SP. 
5. The higher amount of hydration products in the samples with SP blend results in higher compressive strength values (up to $20 \%$ after 28 days of hardening) compared to the control and samples with individual SP.

6. The addition of MWCNTs $(0.005 \%)$ in interaction with the SP blend and the airentraining admixture increases the cement stone's open porosity, promotes a fine-pore structure, and due to reinforcing effect increase the compressive strength. After 28 days of hardening, the compressive strength and open porosity of samples increased by $13.6 \%$ and $5 \%$, and density decreased by $11 \%$.

7. Based on the research results, a composite with better properties than aerated concrete was developed. In the composite without MWCNTs additive, the density and compressive strength regularly decrease from 830 to $310 \mathrm{~kg} / \mathrm{m}^{3}$ and from 6.5 to $0.7 \mathrm{MPa}$ as the amount of PPT waste increases. Due to the interaction of MWCNTs with the SP blend and the air-entraining admixture, the moulding compositions incorporate more air, leading to decreased samples density from 7 to $21 \%$.

8. Due to the reinforced effect of MWCNTs and a higher amount of hydration products, the compressive strength values increased from 3 to $33 \%$ higher than in the formulations without the MWCNTs additive.

9. The highest increase in strength was observed in compositions with a PPT/PPN ratio of $2 / 2$ and $3 / 1$. Their structural efficiency is $71.2 \%$ and $85.2 \%$ higher compared to analogous samples without the MWCNTs.

10. Due to the interaction of MWCNTs with the SP blend and the air-entrainer, moulding mixtures incorporating more air than composites without the addition of MWCNTs, form a fine-pore structure with lower thermal conductivity and better vapour permeability. Increasing the amount of PPT waste in the composite without MWCNTs additive, the thermal conductivity coefficient decreases from 0.233 to $0.09671 \mathrm{~W} /(\mathrm{m} \cdot \mathrm{K})$, and in similar compositions with this additive, the thermal conductivity coefficient decreases by $4-18 \%$. 
Priedai $^{3}$

A priedas. Autoriaus sąžiningumo deklaracija

B priedas. Bendraautoriu sutikimai teikti publikacijose skelbtą medžiagą daktaro disertacijoje

C priedas. Autoriaus moksliniu publikaciju disertacijos tema kopijos

${ }^{3}$ Priedai pateikiami pridètoje kompaktinèje plokštelëje. 
Dainius LEONAVIČIUS

CEMENTINIO KOMPOZITO

SU POLISTIRENINIO PUTPLASČIO

TECHNOLOGINĖMIS ATLIEKOMIS KŪRIMAS

Daktaro disertacija

Technologijos mokslai, medžiagų inžinerija (T 008)

DEVELOPMENT OF CEMENT COMPOSITE WITH POLYSTYRENE FOAM

TECHNOLOGICAL WASTE

Doctoral Dissertation

Technological Sciences,

Materials Engineering ( $T$ 008)

202105 07. 14,5 sp. I. Tiražas 20 egz.

Leidinio el. versija https://doi.org/10.20334/2021-023-M

Vilniaus Gedimino technikos universitetas,

Saulètekio al. 11, 10223 Vilnius

Spausdino Bl UAB „Baltijos kopija“

Kareivių g. 13B, 09109 Vilnius 